UNIVERSIDADE DE SÃO PAULO

FACULDADE DE FILOSOFIA, LETRAS E CIÊNCIAS HUMANAS

DEPARTAMENTO DE GEOGRAFIA

PROGRAMA DE PÓS-GRADUAÇÃO EM GEOGRAFIA FÍSICA

LARISSA LUCCIANE VOLPE

\title{
Análise da paisagem no entorno dos eixos viários: o exemplo do Rodoanel Mario Covas na RMSP
}




\section{Análise da paisagem no entorno dos eixos viários: o exemplo do Rodoanel Mario Covas na RMSP}

Dissertação de Mestrado apresentada a Faculdade de Filosofia, Letras e Ciências Humanas da Universidade de São Paulo.

Área de Concentração: Geografia Física

Orientadora: $\operatorname{Prof}^{\mathrm{a}}$. Dr ${ }^{\mathrm{a}}$. Magda Adelaide Lombardo 
Nome: VOLPE, Larissa Lucciane

Título: Análise da paisagem no entorno dos eixos viários: o exemplo do Rodoanel Mário Covas na RMSP

Dissertação apresentada a banca examinadora do Programa de Pós Graduação em Geografia Física da Faculdade de Filosofia, Letras e Ciências Humanas da Universidade de São Paulo para obtenção do título de Mestre em Ciências na área de concentração em Geografia Física.

Trabalho aprovado pela banca examinadora em:

Profa. Dra. Magda Adelaide Lombardo (orientadora) Instituição:

Julgamento:

Assinatura:

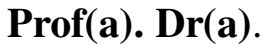

Instituição:

Julgamento:

Assinatura:

$\operatorname{Prof(a).~Dr(a).~}$

Instituição:

Julgamento:

Assinatura: 
Dedico este trabalho aos meus pais, sempre presentes em minha vida acadêmica.

A minha avó Ondina pelo exemplo de uma vida de força e luta. 


\section{SUMÁRIO}

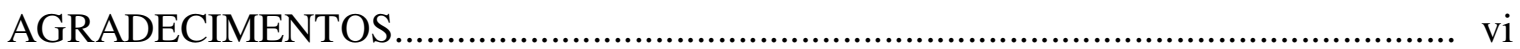

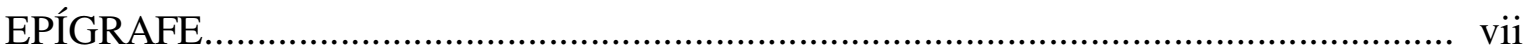

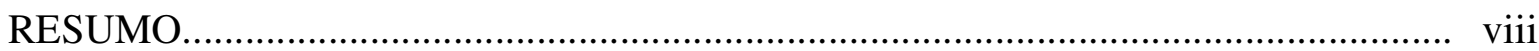

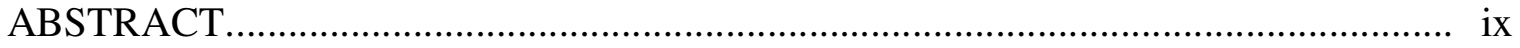

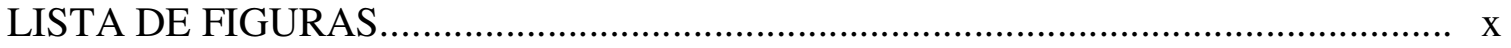

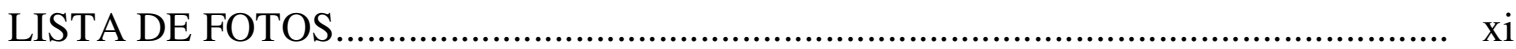

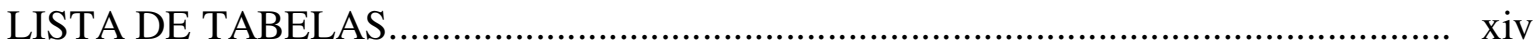

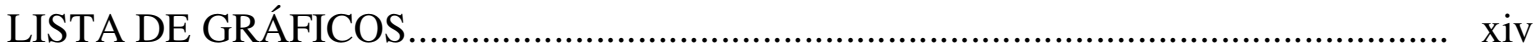

SIGLAS EM ORDEM ALFABÉTICA......................................................... $\mathrm{xV}$

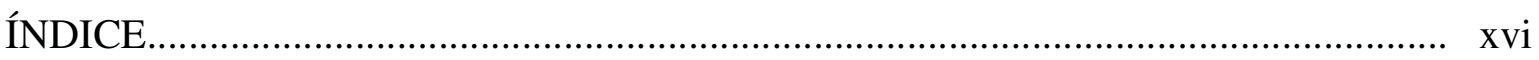


As Agências de Fomento a Pesquisa Capes e CNPq pelo financiamento desta pesquisa.

A Prof $^{a} \operatorname{Dr}^{\mathrm{a}}$ Magda Adelaide Lombardo pela orientação da pesquisa e pelo apoio nas publicações e participações em eventos científicos que muito enriqueceram meus estudos.

A Universidade de São Paulo (FFLCH / USP), principalmente às secretárias Cida, Ana, e Rosângela e aos coordenadores da Pós Graduação em Geografia Física Prof. Dr. Ailton Luchiari e Prof. Dr. Emerson Galvani pela atenção e apoio em questões burocráticas.

Aos professores que fizeram parte da banca do Exame de Qualificação, Prof. Dr. Marcelo Martinelli e Prof. Dr. Luis Antonio Bittar Venturi, que muito acrescentaram à pesquisa com suas sugestões.

Ao funcionário Benê do Laboratório de Aeorofotogrametria - LASERE pelo auxílio nas buscas das fotografias aéreas; a Rubia pelo apoio na utilização do Laboratório.

Ao mestrando da UNESP e companheiro Jeferson M. R. M. F. Lourenço pela paciência, pelo auxílio com as revisões do texto durante o desenvolvimento da pesquisa e pelas discussões sobre o tema que muito enriqueceram o trabalho.

Ao IBGE de Rio Claro pelo serviço oferecido com as cartas topográficas.

Ao superintendente da empresa DERSA, da cidade de São Paulo, Milton Xavier, pela entrevista concedida e documentos cedidos sobre o Rodoanel trecho oeste e sua construção.

A doutoranda da USP Amanda Ramalho Vasques pelo auxílio, incentivo, apoio operacional e principalmente pela sincera amizade durante todo o desenvolvimento da pesquisa. Agradeço também a sua família por me acolher e apoiar com tanto carinho durante estes anos. Obrigada Dona Raquel e Sr. Edson Vasques.

Ao doutorando da USP Jefferson Lordelo Polizel pelo auxílio no trabalho com a imagem IKONOS e pelas caronas até a USP. Ao Laboratório de Métodos Quantitativos do Departamento Florestal da ESALQ / USP pelo apoio e esclarecimentos sobre SIG.

Ao doutorando da UNESP Rubens Hardt pelo auxílio nas dúvidas com o programa Spring 4.3.3.

Aos mestrandos da UNESP de Rio Claro Mateus Vidotti Ferreira e Eduardo Magalhães Borges Prata pelo auxílio com o programa ArcGis 9.2.

Ao meu pai, exímio morador da cidade de São Paulo, pelas informações sobre a cidade, pelo apoio operacional no desenvolvimento do trabalho e pelos incansáveis trabalhos de campo.

A minha mãe, pelo apoio incondicional em todas as minhas decisões.

Aos meus irmãos, ao vô Pedro, a vó Ondina não mais presente, pela compreensão do meu afastamento de casa durante os anos de dedicação à pesquisa.

A minha querida sogra D. Arlete e tia Eunice, professoras de Língua Portuguesa, pelas correções gramaticais.

A amiga Letícia Giuliana Paschoal pelo auxílio com informações relevantes da área estudada. A todos os amigos do CEAPLA/UNESP Rio Claro que sempre me ofereceram apoio.

Obrigada! 
"Por mais longa que seja a caminhada o mais importante é dar o primeiro passo."

Vinícius de Moraes 
VOLPE, L. L. Análise da paisagem no entorno dos eixos viários: o exemplo do Rodoanel Mario Covas na RMSP. 2009. 211f. Dissertação (Mestrado em Geografia Física) - Faculdade de Filosofia, Letras e Ciências Humanas, Universidade de São Paulo, São Paulo, 2009.

A construção de uma rodovia pode interferir na dinâmica urbana, transformando a paisagem em seu entorno, e isto pode ocorrer devido a diversos fatores como instalações de empreendimentos, novas ocupações residenciais, mudanças na dinâmica e na fisionomia das áreas já ocupadas. Neste trabalho, o objetivo do estudo da paisagem urbana ao longo de um eixo viário, que tem como função interligar outras rodovias, é analisar de que forma ocorrem as alterações na paisagem urbana e sua abrangência. $O$ estudo das transformações da paisagem urbana no entorno do eixo viário Rodoanel trecho oeste nos bairros de Perus e Jaraguá na cidade de São Paulo foi trabalhada por meio de levantamento de dados de diversas fontes e utilização de geotecnologias. As geotecnologias unidas às informações provenientes de documentos e trabalhos de campo, auxiliaram na organização, gerenciamento e quantificação dos dados. Os resultados obtidos foram organizados nos mapas temáticos de área construída, área verde densa, gramínea e árvores esparsas, área de solo exposto e galpões. Estes mapas temáticos permitiram uma caracterização de um cenário no entorno do trecho oeste do Rodoanel Mario Covas nos bairros Perus e Jaraguá, com as alterações ocorridas desde o ano de 1994 até 2002, isto é, uma análise temporal. Para alcançar estes resultados foi trabalhado em ambiente SIG dois tipos de classificação digital, a analógica e a automática, sendo o método analógico realizado na imagem IKONOS e também nas fotografias aéreas; e o método automático realizado apenas na imagem de alta resolução IKONOS. Foram comparados os dois métodos e observado que a classificação analógica foi mais adequada para a realização da análise multitemporal por ter sido realizada da mesma forma nas duas fontes, nas fotos aéreas de 1994 e na imagem IKONOS de 2002; e também permitiu uma melhor visualização nos mapas temáticos por considerar áreas maiores que a classificação automática. Com a análise temporal foi possível concluir que, do ano de 1994 ao ano de 2002, a área verde densa aumentou, a área de gramínea e árvores esparsas diminuiu, a área de solo exposto diminuiu, a área construída aumentou e a área de galpões de 1984 a 2002 também aumentou. As imagens aéreas de 1994 e 2002 também foram comparadas com os trabalhos de campo realizados nos anos de 2006, 2007, 2008 e 2009, onde foi possível observar as transformações ocorridas neste período. Nesta análise, os resultados foram divididos em alterações positivas, neutras e negativas, como sugere relatório desenvolvido pela empresa responsável pela construção do trecho oeste do Rodoanel Mario Covas, e de acordo com as observações realizadas em campo e no âmbito bibliográfico. Concluiu-se aproximadamente $48 \%$ de alterações consideradas negativas, $41 \%$ positivas e $12 \%$ neutras na área de estudo.

Palavras-chave: Paisagem Urbana - Eixos Viários - Rodoanel Mario Covas - RMSP Geotecnologias 
VOLPE, L. L. Landscape analysis over the road axle's proximities: the example of Mario Covas Expressway on RMSP. 2009. 211f. Dissertation (Masters in Physics Geography) Philosophy, Letters and Human Studies School, University of São Paulo, São Paulo, 2009.

The construction of a highway may interfere on the urban dynamics and transform the landscape in its surroundings and this might occur due to several factors as installations of new undertakings, new residential constructions, changes on the dynamics and appearance in already occupied areas. In this work, the objective in the study of the urban landscape on the surroundings of a expressway axle, that have the function to link other highways, is to analyze in which way the landscape changes occur and its range. The transformations study of the urban landscape on the surroundings of the Mario Covas Expressway, east part, on the districts of Perus and Jaraguá, was developed through the gathering of data from several sources and the use of geotechnologies. The geotechnologies united to the data from documents and field works, aided the organization, managing and quantification of the data. The results obtained were organized on thematic maps of the built area, dense green area, grass and sparse trees, exposed soil and warehouses. These thematic maps allowed a characterization of the surroundings scenario of the East part of the Mario Covas Expressway on the São Paulo districts of Perus an Jaraguá, with a temporal analysis of the changes that took place from the year of 1994 through 2002. To reach these results two types of digital classification were worked over a GIS environment: the analogic and the automatic, being the analogical method constructed over the IKONOS imagery and also over aerial photographs; and the automatic method constructed exclusively over the IKONOS high resolution imagery. The two methods were compared and observed that the analogic classification was more suited to the multitemporal analysis due to the use of the same methods on both sources, on 1994 aerial imagery and 2002 high resolution imagery; and also allowed a better visualization on the thematic maps for considering larger regions than the automatic classification. With the multitemporal analysis was possible to conclude that, from 1994 through 2002 year, the dense green area increased, the grass and sparse tree area decreased, the exposed soil area decreased, the constructed area increased and warehouses area, from 1984 to 2002 also increased. The aerial images from 1994 and 2002 also were compared with the field work developed on 2006, 2007, 2008 and 2009, where was possible to observe the transformations that took place throughout this period. In this analysis, the results was divided in positive, neutral and negative alterations, as suggests report developed by the responsible company for the construction of the East part of the Mario Covas Expressway and according to the observations carried out on the field and over the bibliography extent. The conclusion is that approximately $48 \%$ of the transformations are considered negative, $41 \%$ positive and $12 \%$ neutral over the study area.

Key-words: Urban landscape - roads axles - Mario Covas Expressway - RMSP geotechnologies 


\section{LISTA DE FIGURAS}

Figura 1: Localização do estado de São Paulo no Brasil e da RMSP.................................................... 38

Figura 2: Mosaico Aerofotogramétrico (2002).......................................................................... 47

Figura 3: Localização do Rodoanel na RMSP .......................................................................... 58

Figura 4: Localização do Rodoanel na RMSP................................................................................ 58

Figura 5: Área de estudo com buffer de $2 \mathrm{~km}$ do eixo viário (municípios de São Paulo e

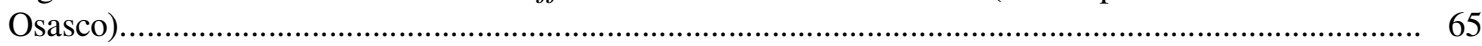

Figura 6: Imagem aérea utilizada para estudo do trecho oeste do Rodoanel (municípios de São Paulo

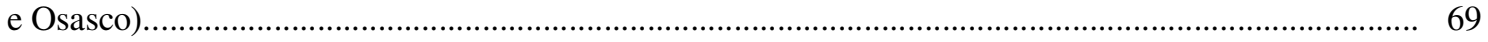

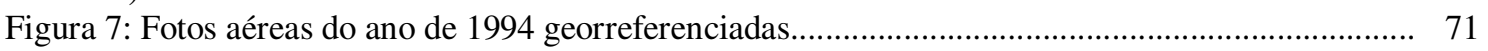

Figura 8: Imagem aérea de alta resolução do ano de 2002 georreferenciada......................................... 72

Figura 9: Classificação analógica na imagem IKONOS do ano de 2002 ……....................................... 76

Figura 10: Imagem segmentada (Spring 4.3.3)....................................................................... 78

Figura 11: Exemplo de classificação automática supervisionada por regiões Bhattacharya $75 \%$........ $\quad 79$

Figura 12: Classes atribuídas pela autora após a classificação automática supervisionada (Spring)... $\quad 80$

Figura 13: Elaboração da legenda após exportação de dados (ArcGis)................................................... 80

Figura 14: Classificação automática na imagem IKONOS do ano de 2002 ............................................ 81

Figura 15: Presença de área verde densa em 1994 e 2002 .......................................................................... 84

Figura 16: Presença de gramíneas e árvores esparsas em 1994 e 2002 ................................................ 85

Figura 17: Presença de solo exposto em 1994 e 2002 ........................................................................ 86

Figura 18: Presença de área construída em 1994 e 2002 .................................................................. 87

Figura 19: Presença de galpões em 1994 e 2002......................................................................... 88

Figura 20: Gramínea e árvores esparsas na fotografia aérea do ano de 1994 ao lado da linha férrea.. $\quad 90$

Figura 21: Árvores e vegetação alta na imagem do ano de 2002 ao lado da linha férrea....................... 90

Figura 22: Gramínea e árvores esparsas na fotografia aérea do ano de 1994 próxima a rodovia dos

Bandeirantes.

Figura 23: Árvores e vegetação alta na imagem do ano de 2002 próxima a rodovia dos Bandeirantes 90

Figura 24: Gramínea na fotografia aérea do ano de 1994 próxima a linha férrea e ao futuro traçado do

Rodoanel..

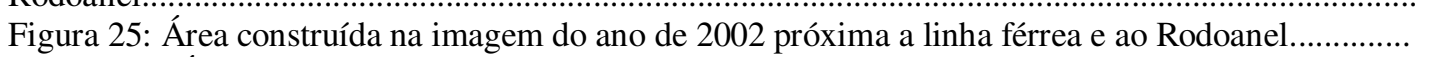

Figura 26a: Área de solo exposto ocupada por residências......................................................................... 92

Figura 26b: Área de solo exposto ocupada por vegetação em processo de readequação.......................... 92

Figura 27: Área de gramínea no ano de 1994 próxima ao eixo ferroviário............................................... 94

Figura 28: Área de gramínea no ano de 2002 próxima ao eixo ferroviário e ao Rodoanel....................... 94

Figura 29: Localização e situação dos galpões nos anos de 1984, 1994 e 2002 ………............................ 96

Figura 30: Vila Nova, Recantos dos Humildes e Recanto da Paz em 1994.......................................... 102

Figura 31: Vila Nova, Recantos dos Humildes e Recanto da Paz em 2002 ........................................... 102

Figura 32: Jardim Anhanguera, Jardim Jaraguá e Vila Sulina em 1994_................................................. 103

Figura 33: Jardim Anhanguera, Jardim Jaraguá e Vila Sulina em 2002 .............................................. 103

Figura 34: Jardim Adelfiori e Vila Hungaresa em 1994 .................................................................. 105

Figura 35: Jardim Adelfiori e Vila Hungaresa em 1994_................................................................. 105

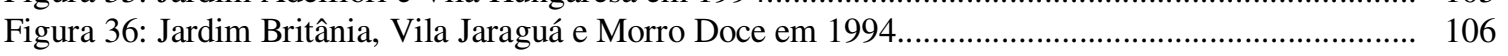

Figura 37: Jardim Britânia, Vila Jaraguá e Morro Doce em 2002 ………………………..................... 106

Figura 38: Vila Jaraguá, Morro Doce, Morro Doce III, Jardim Anhanguera, Jardim Itaberaba, Jardim Itaberaba II, Jardim Esperança, Jardim Jaraguá e Vila Sulina em 1994................................................ 107

Figura 39: Vila Jaraguá, Morro Doce, Morro Doce III, Jardim Anhanguera, Jardim Itaberaba, Jardim Itaberaba II, Jardim Esperança, Jardim Jaraguá e Vila Sulina em 2002 .............................................. 107

Figura 40: Morada do Sol e Vila Sol Nascente em 1994............................................................. 108

Figura 41: Morada do Sol e Vila Sol Nascente em 2002............................................................. 108

Figura 42: Informes sobre melhorias nas Vilas Morada do Sol e Sol Nascente em Perus (São Paulo-

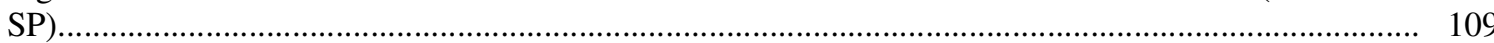

Figura 43: Informes sobre melhorias nas Vilas Morada do Sol e Sol Nascente em Perus (São PauloSP)

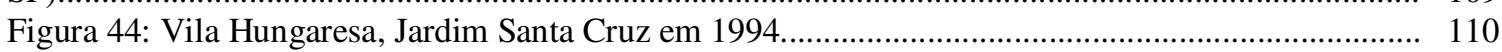

Figura 45: Vila Hungaresa, Jardim Santa Cruz em 2002 ................................................................. 110

Figura 46: Jardim Ipanema e Vila Homero em 1994 ......................................................................... 111

Figura 47: Jardim Ipanema e Vila Homero em 2002 …….......................................................... 111

Figura 48: Jardim Itaberaba, Jardim Itaberaba II, Jardim Anhanguera, Jardim Esperança, Jardim Jaraguá em 1994................................................................................................................ 112 
Figura 49: Jardim Itaberaba, Jardim Itaberaba II, Jardim Anhanguera, Jardim Esperança, Jardim Jaraguá em 2002.

Figura 50: Jardim Ipanema em 1994 .......................................................................................... 113



Figura 52: Jardim Ipanema, Vila Aurora, Vila Santa Lucrecia em 1994........................................... 114

Figura 53: Jardim Ipanema, Vila Aurora, Vila Santa Lucrecia em 2002 ............................................ 114

Figura 54: Jardim Rincão, Recanto da Paz, Recanto dos Humildes e Jardim Ipanema em 1994........... 115

Figura 55: Jardim Rincão, Recanto da Paz, Recanto dos Humildes e Jardim Ipanema em 2002............ 115

Figura 56: Jardim Santa Fé no município de Osasco em 1994 ............................................................. 117

Figura 57: Jardim Santa Fé no município de Osasco em 2002 ........................................................ 117

Figura 58: Pontos de referência na fotografia aérea de 1994.............................................................. 118

Figura 59: Pontos de referência na imagem IKONOS 2002 ......................................................... 119

\section{LISTA DE FOTOS}

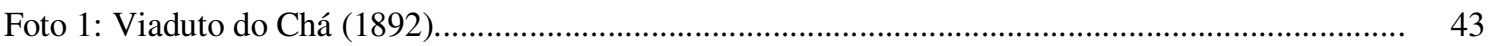

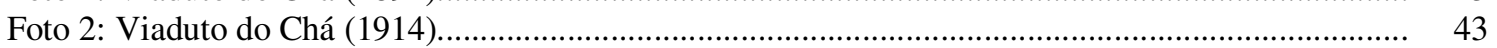

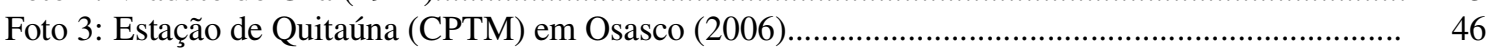

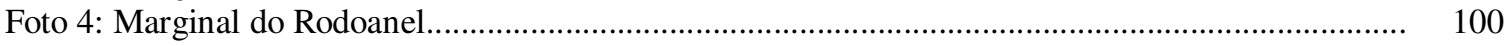

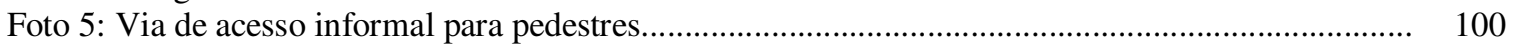

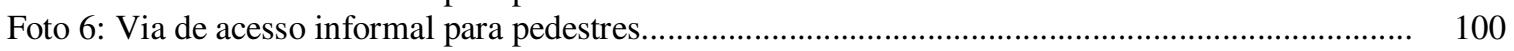



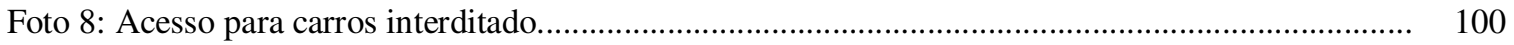

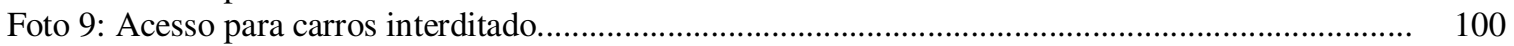



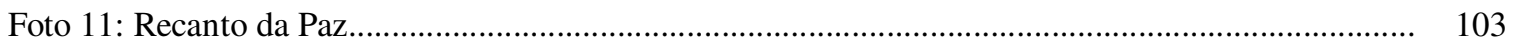



Foto 13: Vila Sulina e passagem informal para pedestres............................................................ 104

Foto 14: Vila Hungaresa no bairro de Perus................................................................................ 105

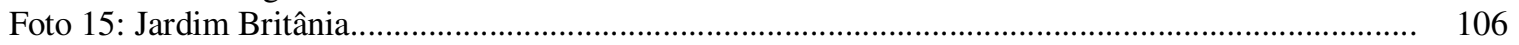

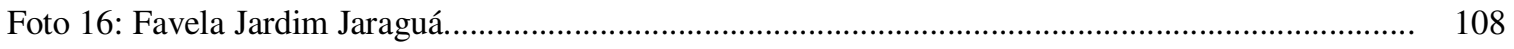

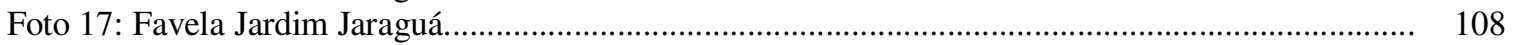

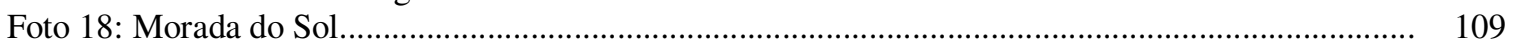

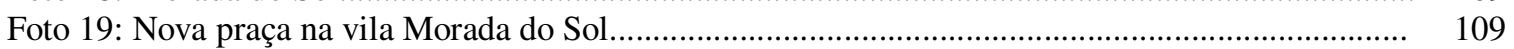

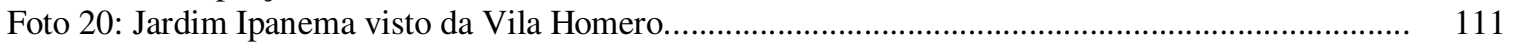

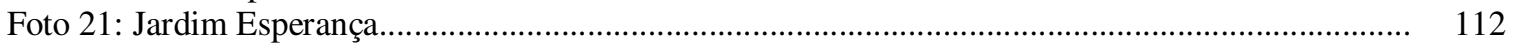

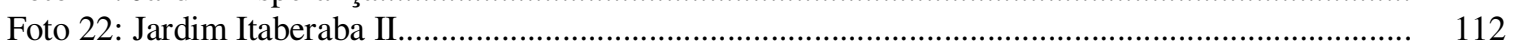

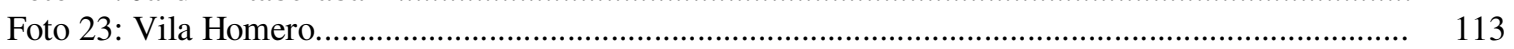

Foto 24: Indústria e ocupação residencial no entorno (Jardim Ipanema e Jardim Sta Lucrecia)........... 114



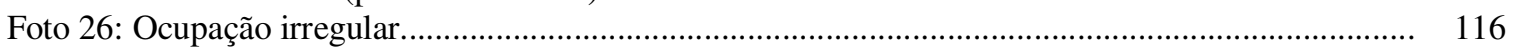

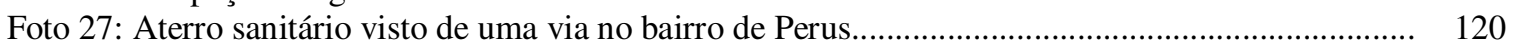

Foto 28: Aterro sanitário visto do Rodoanel............................................................................... 120

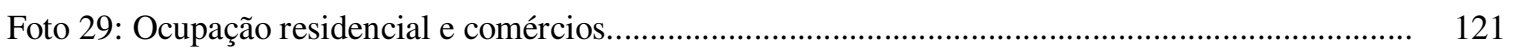

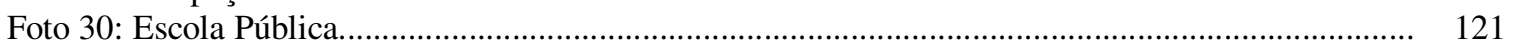

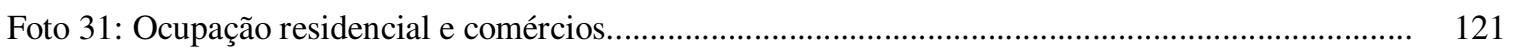

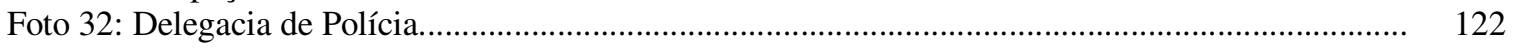

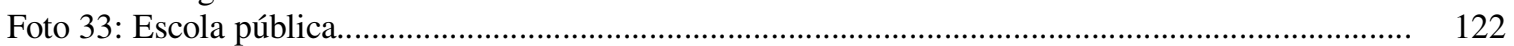

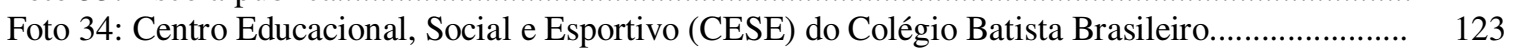

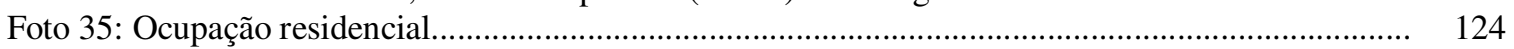

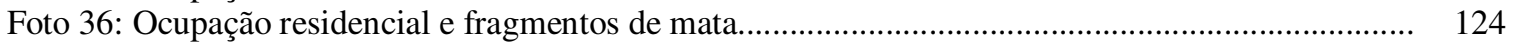

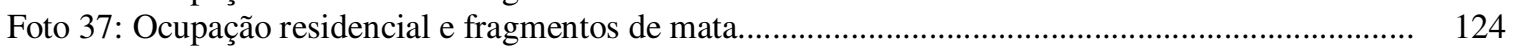

Foto 38: Casas de alto padrão e fragmento de mata............................................................................ 125

Foto 39: Casas de alto padrão e fragmento de mata.......................................................................... 125

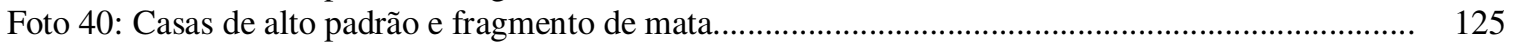

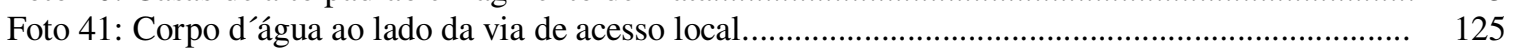

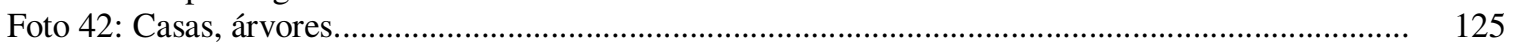

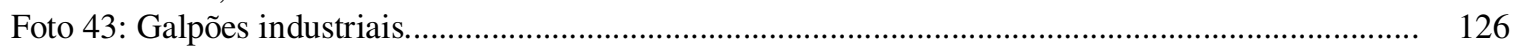

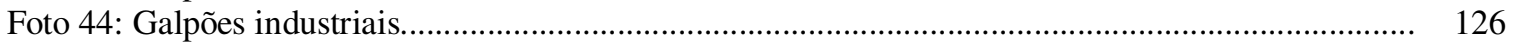

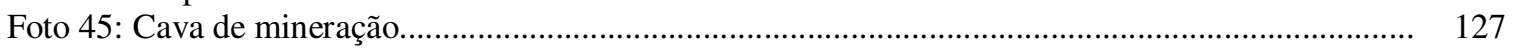






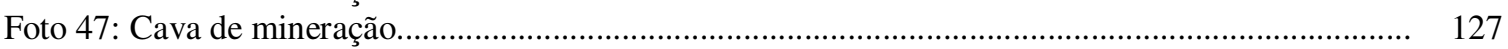

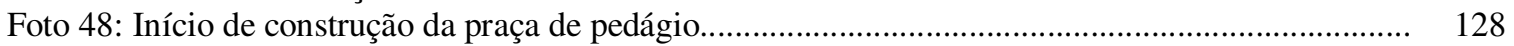

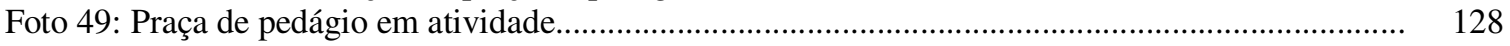

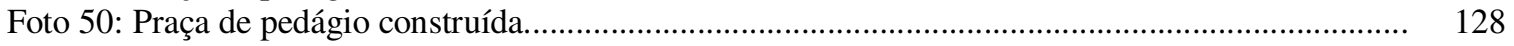

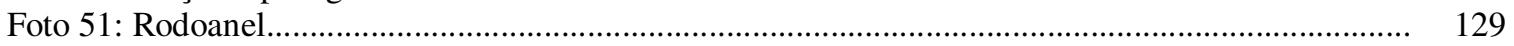



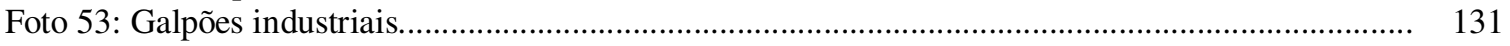

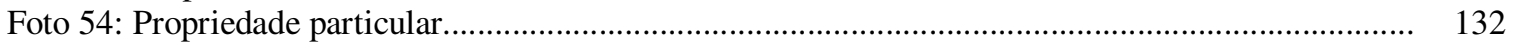

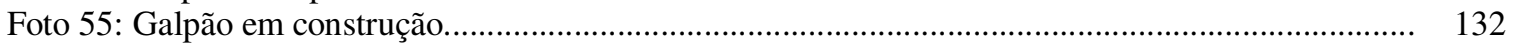

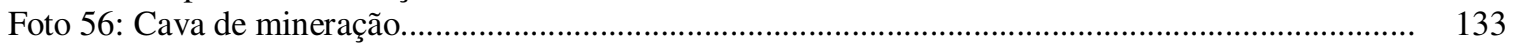

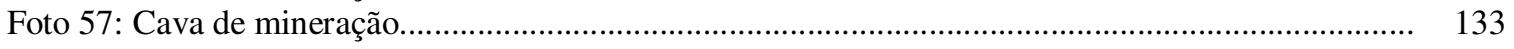

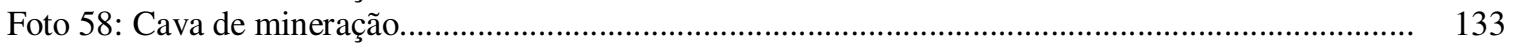

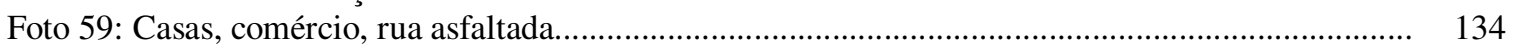

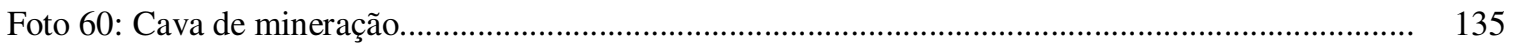

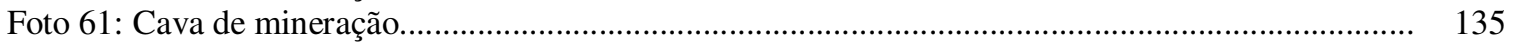

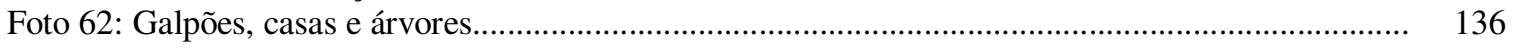

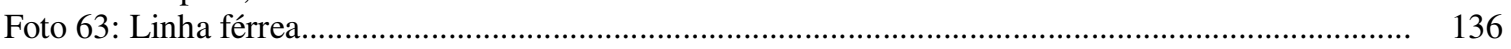

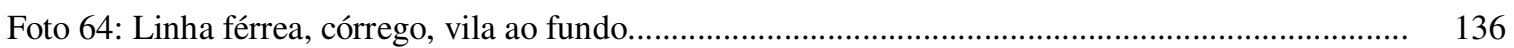

Foto 65: Alças de acesso ao Rodoanel e ocupação residencial......................................................... 137

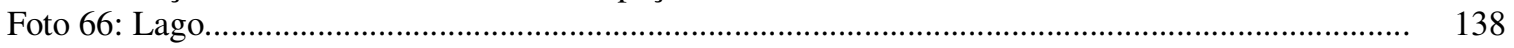



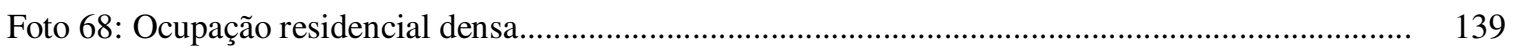

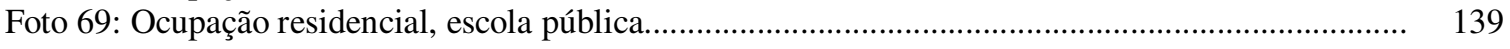



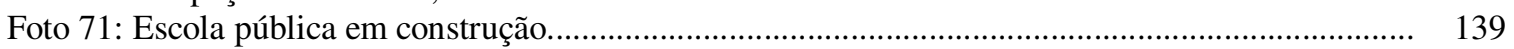

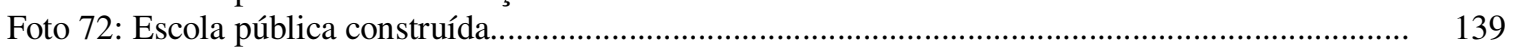

Foto 73: Rodovia, fragmento de mata e ocupação residencial....................................................... 140

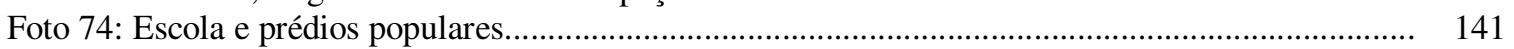

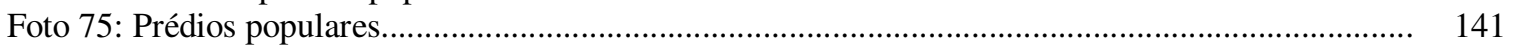

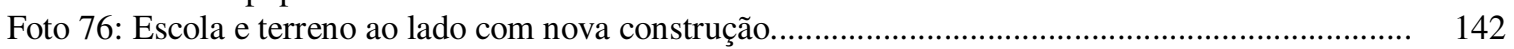

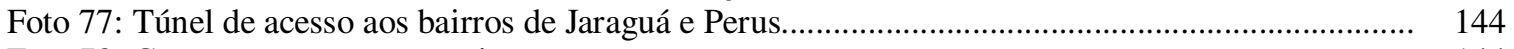

Foto 78: Construção, mata e estacionamento............................................................................... 144

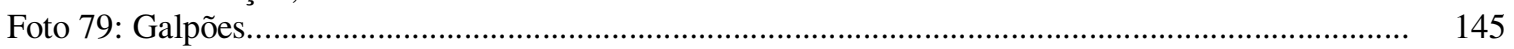

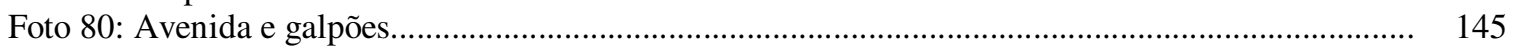

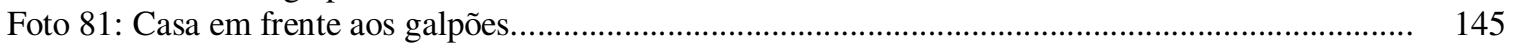

Foto 82: Via asfaltada, ocupação residencial, galpão a direita....................................................... 146

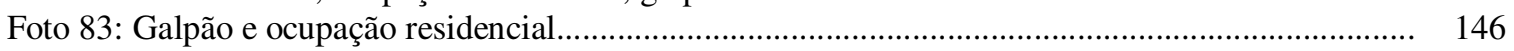

Foto 84: Antena no Pico do Parque do Jaraguá............................................................................... 147

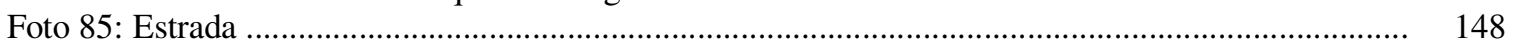

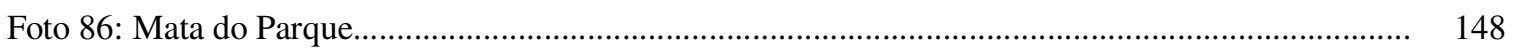



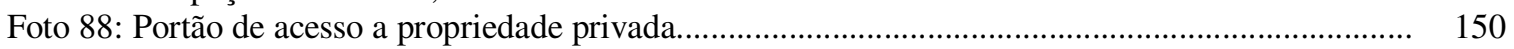

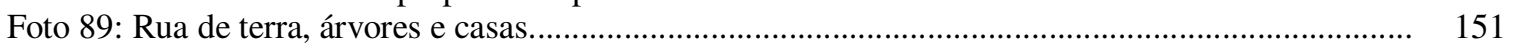

Foto 90: Ocupação residencial densa vista da rodovia Bandeirantes................................................ 152

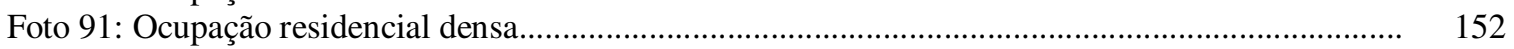

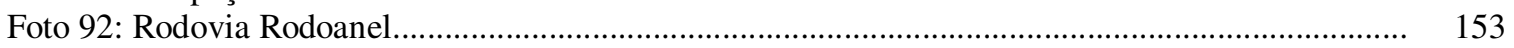



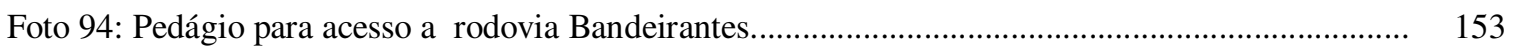

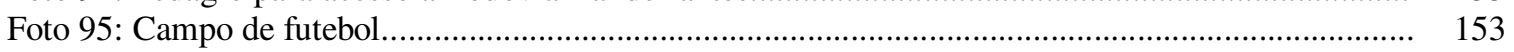

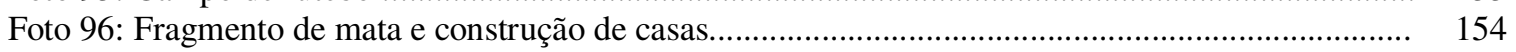

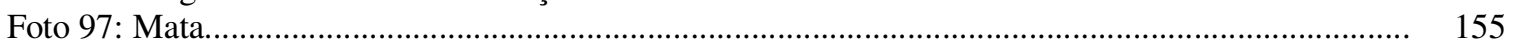

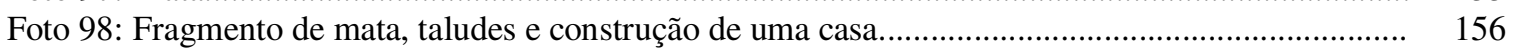

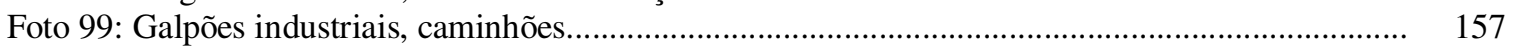

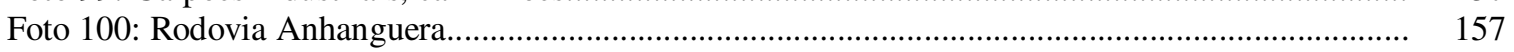

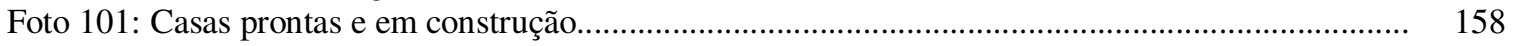



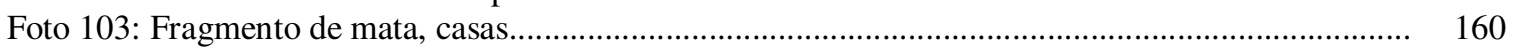

Foto 104: Portão de propriedade particular, fragmento de mata....................................................... 161

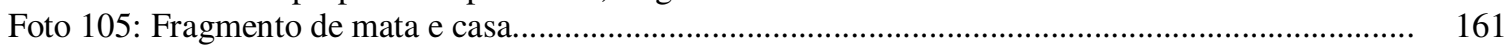




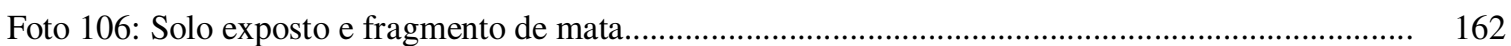

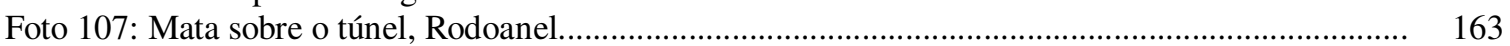

Foto 108: Mata sobre o túnel, Rodoanel, ocupação residencial densa a direita.................................... 163

Foto 109: Mata sobre o túnel, Rodoanel, ocupação residencial densa a direita.................................... 163

Foto 110: Entrada do túnel e ocupação residencial densa a direita, Rodoanel..................................... 164

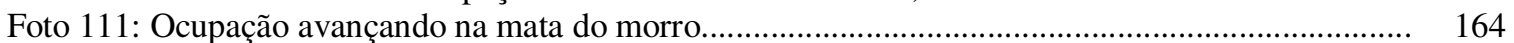

Foto 112: Entrada do túnel e ocupação residencial densa a direita, Rodoanel..................................... 164

Foto 113: Entrada do túnel e ocupação residencial densa a direita, Rodoanel, casa e posto da DERSA a esquerda.

Foto 114: Ocupação e rodovia (Rodoanel)

Foto 115: Morro em cima do túnel, ocupação residencial densa....................................................... 164

Foto 116: Ocupação residencial densa, ruas asfaltadas, mata (Morro de Jesus)................................... 165

Foto 117: Ocupação residencial densa, ruas asfaltadas, mata.......................................................... 165

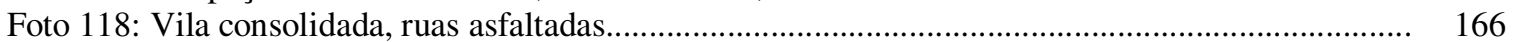

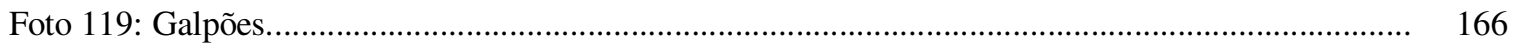



Foto 121: Ocupação residencial densa em terreno íngreme............................................................ 167

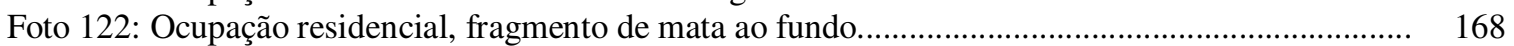

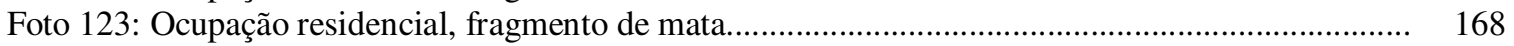

Foto 124: Ocupação residencial, fragmento de mata....................................................................... 169

Foto 125: Árvores, via de acesso de terra, construções, terreno íngreme........................................... 170

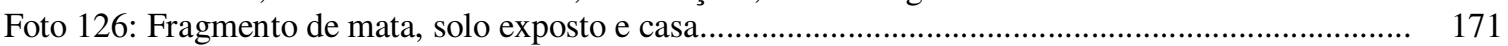

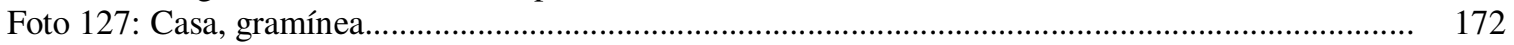

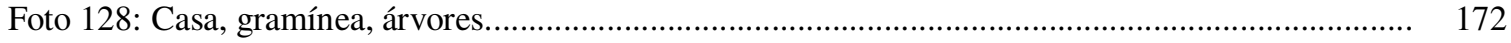



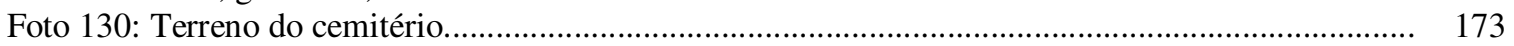

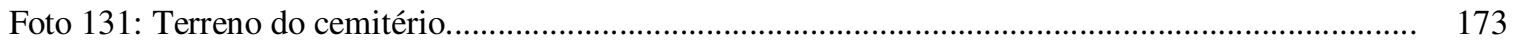

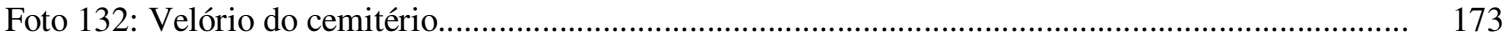

Foto 133: Rodovia Anhanguera, entrada do cemitério.......................................................................... 174

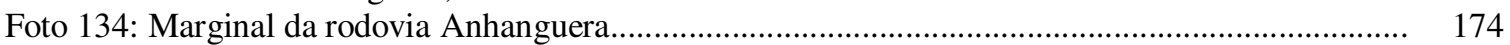

Foto 135: Ocupação residencial densa, árvores esparsas, terreno íngreme......................................... 175

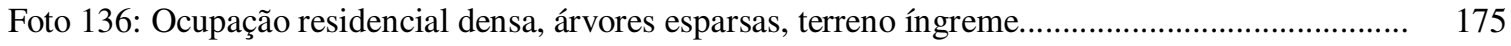

Foto 137: Cruzamento das rodovias Anhanguera e Rodoanel, vila..................................................... 176

Foto 138: Casa, talude e vila ao fundo.................................................................................... 177

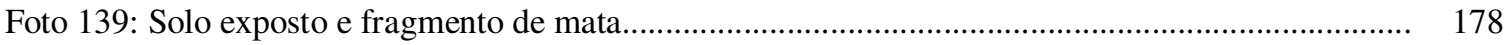

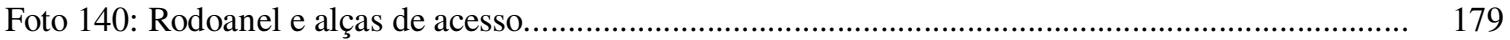

Foto 141: Rodoanel, ocupação residencial e acesso formal............................................................. 180

Foto 142: Ocupação residencial densa..................................................................................... 180

Foto 143: Ocupação residencial densa e Rodoanel.................................................................... 180

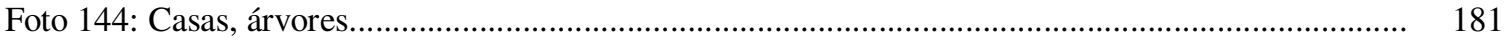

Foto 145: Escola, ocupação residencial.................................................................................. 182

Foto 146: Ocupação residencial e árvores.................................................................................. 183

Foto 147: Rua asfaltada, terrenos com árvores a esquerda e construções a direita............................ 183

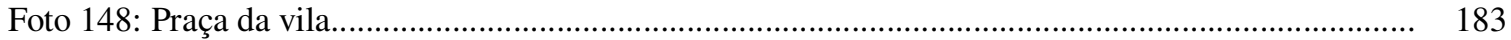

Foto 149: Acesso informal para carros interditado...................................................................... 184

Foto 150: Rodoanel e acesso a favela na marginal....................................................................... 184

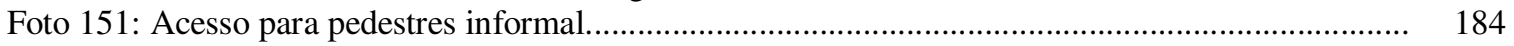

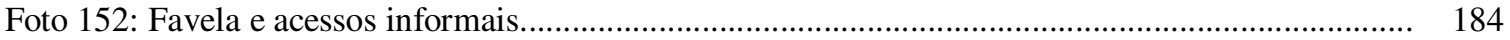

Foto 153: Favelização com acesso informal ao Rodoanel.............................................................. 185

Foto 154: Favela, campinho de lazer........................................................................................... 185

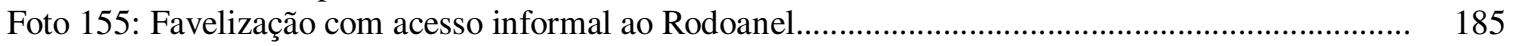

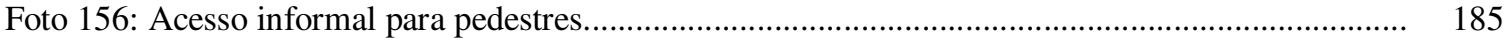

Foto 157: Acesso informal para pedestres................................................................................. 185

Foto 158: Acesso informal para pedestres................................................................................. 185

Foto 159: Casas em construção, via de acesso para pedestres e cerca................................................. 186

Foto 160: Casas em construção, via de acesso para pedestres e cerca............................................. 186

Foto 161: Casas em construção, via de acesso para pedestres e cerca................................................... 186

Foto 162: Casas em construção, via de acesso para pedestres e cerca................................................ 186

Foto 163: Ocupação nos dois lados da rodovia.............................................................................. 186

Foto 164: Alças de retorno passando por baixo do Rodoanel........................................................... 187 


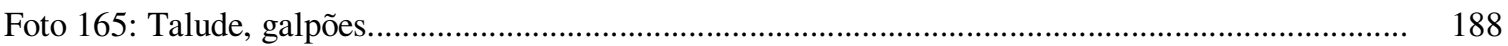

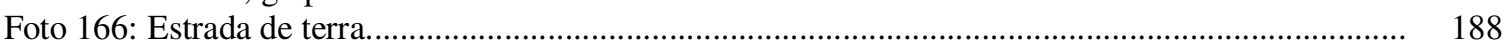

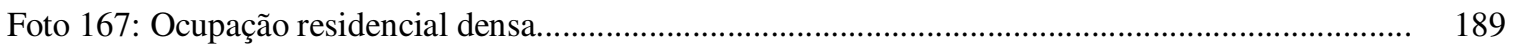

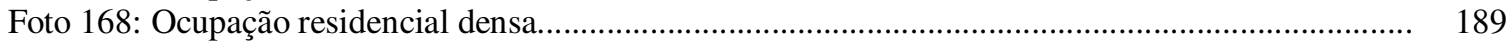

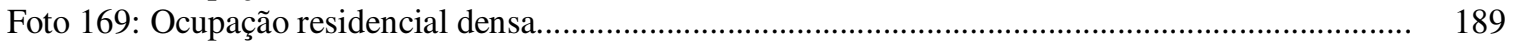

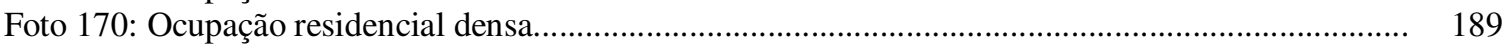

Foto 171: Ocupação residencial em terrenos íngremes......................................................................... 189

Foto 172: Jardim Adelfiori e a frente Recanto dos Humildes......................................................... 189

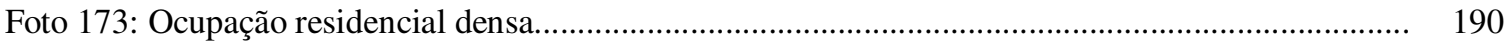

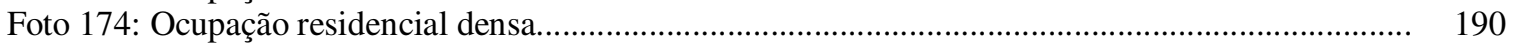

Foto 175: Ocupação residencial em terreno íngreme..................................................................... 190

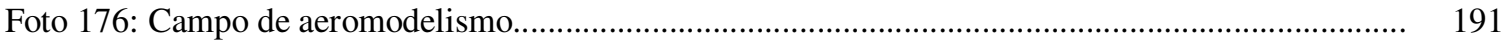

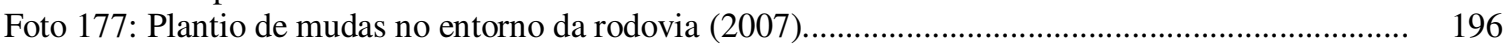

Foto 178: Plantio de mudas no entorno da rodovia (2007).............................................................. 196

\section{LISTA DE TABELAS}

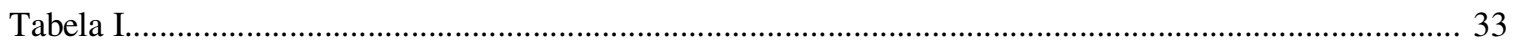

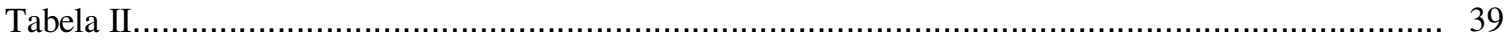

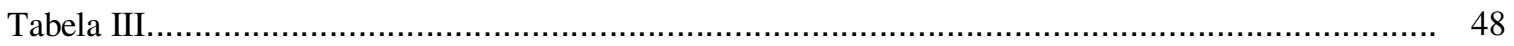

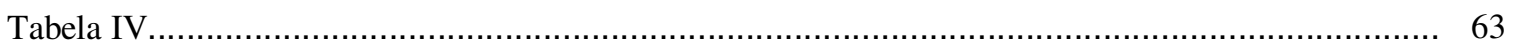

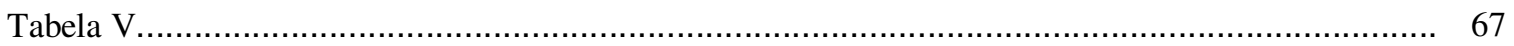

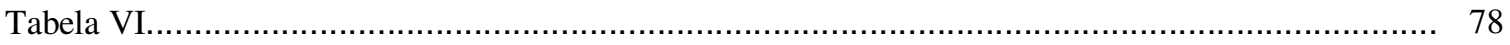

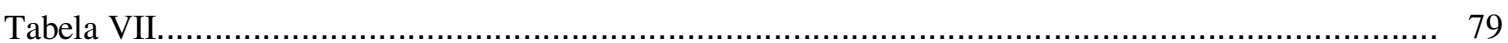

\section{LISTA DE GRÁFICOS}

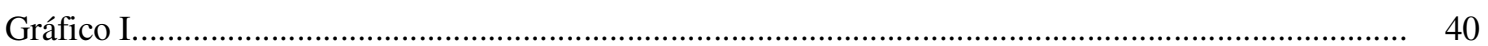

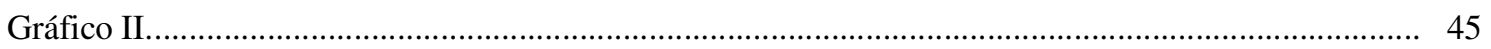



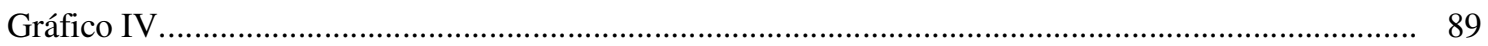

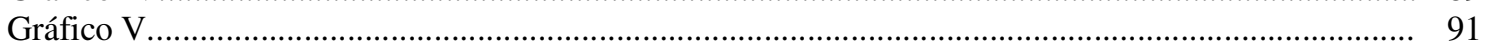

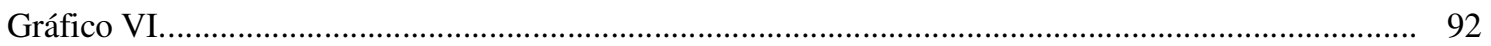

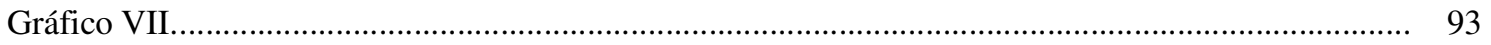

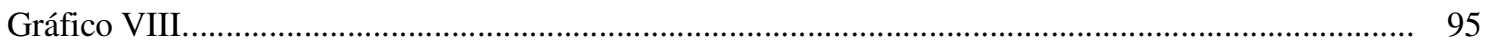

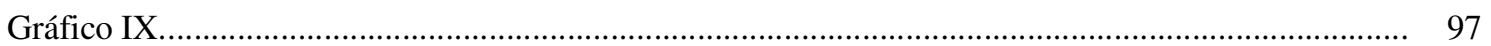

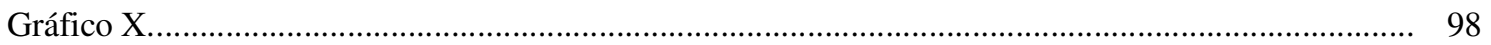

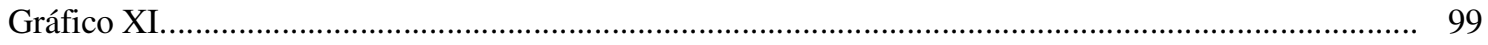

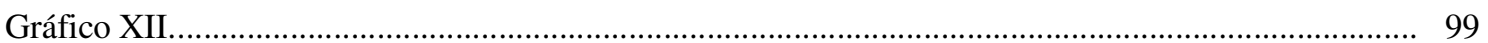


SIGLAS EM ORDEM ALFABÉTICA

AAE: Avaliação Ambiental Estratégica

CAPES: Coordenação e Aperfeiçoamento de Pessoal de Nível Superior CIEFP: Companhia Industrial Estrada de Ferro Perus-Pirapora

CLI: Centros Logísticos Integrados

CNPq: Centro Nacional de Desenvolvimento Científico e Tecnológico

CPTM: Companhia Paulista de Trens Metropolitanos

DERSA: Desenvolvimento Rodoviário S. A.

DNPM: Departamento Nacional de Pesquisas Minerais

EFS: Estrada de Ferro Sorocabana

EIA: Estudo de Impacto Ambiental

EMPLASA: Empresa Paulista de Planejamento Metropolitano S. A.

FFLCH: Faculdade de Filosofia e Letras e Ciências Humanas

FUNCATE: Fundação de Ciência, Aplicações e Tecnologias Espaciais

IAB - Instituto de Arquitetos do Brasil

IBGE: Instituto Brasileiro de Geografia e Estatística

INPE: Instituto Nacional de Pesquisas Espaciais

LASERE: Laboratório de Sensoriamento Remoto e Aerofotogrametria PDDT: Plano Diretor de Desenvolvimento de Transportes

PDM: Plano Diretor Municipal

RIMA: Relatório de Impacto Ambiental

RFFSA: Rede Ferroviária Federal S. A.

RMSP: Região Metropolitana de São Paulo

SEADE: Fundação Sistema Estadual de Análise de Dados

SIG: Sistemas de Informações Geográficas

USP: Universidade de São Paulo 
INTRODUÇÃO..................................................................................................... 17

JUSTIFICATIVA ............................................................................................................... 19

OBJETIVO GERAL_................................................................................................ 20

OBJETIVOS ESPECÍFICOS........................................................................................... 20

CAPITULO 1. BASES TEÓRICAS E CONCEITUAIS..................................................... 21

1.1 DISCUSSÕES SOBRE A PAISAGEM URBANA................................................ 21

1.2 O USO DA GEOTECNOLOGIA NA REPRESENTAÇÃO DA PAISAGEM

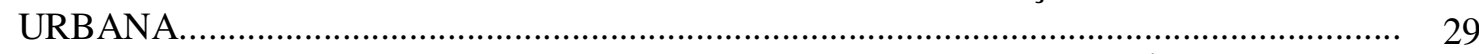

CAPITULO 2. A IMPLANTAÇÃO DOS EIXOS VIÁRIOS E A TRANSFORMAÇÃO DA PAISAGEM URBANA ………………………………………... 33

2.1 CONSIDERAÇÕES SOBRE O CRESCIMENTO URBANO NA RMSP.................... 33

2.2 A CONSTRUÇÃO DE EIXOS VIÁRIOS E AS TRANSFORMAÇÕES NA PAISAGEM URBANA NA RMSP.

2.3 CARACTERÍSTICAS DO TRECHO OESTE DO RODOANEL MARIO COVAS..... 47

2.4 ESTUDOS PRÉVIOS PARA A IMPLANTAÇÃO DE EIXOS VIÁRIOS VISANDO A DIMINUIÇÃO DE IMPACTOS SOCIAIS E AMBIENTAIS............................................ 49

2.5 CARACTERIZAÇÃO DO ENTORNO DO TRECHO ESTUDADO DO RODOANEL MARIO COVAS.

CAPITULO 3. PROCEDIMENTOS METODOLÓGICOS............................................... 62

3.1 DELIMITAÇÃO E ESCALA DA ÁREA DE ESTUDO.............................................. 62

3.2 ANÁLISE DE INFORMAÇÕES SOBRE O ENTORNO DO RODOANEL MARIO COVAS.

3.3 MÉTODOS DE CLASSIFICAÇÃO DIGITAL PARA ANÁLISE DA PAISAGEM URBANA NO ENTORNO DO RODOANEL MARIO COVAS......................................... 74 4. DISCUSSÃO DOS RESULTADOS.............................................................................. 83 4.1 ANÁLISE TEMPORAL DA PAISAGEM URBANA DE 1994 A 2002 POR MEIO DE GEOTECNOLOGIAS E IMAGENS AÉREAS.......................................................... 83 4.2 ANÁLISE COMPARATIVA DAS TÉCNICAS DE CLASSIFICAÇÃO DO USO E

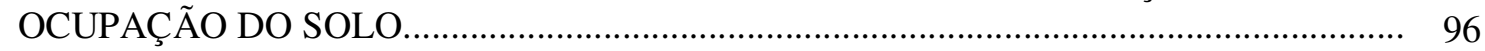
4.3 CARACTERIZAÇÃO E ANÁLISE TEMPORAL POR MEIO DE IMAGENS AÉREAS E TRABALHOS DE CAMPO $(1994-2009)$..................................................... 100

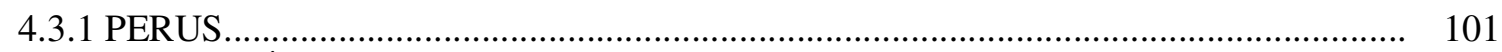
4.3.2 JARAGUÁ ......................................................................................................... 110

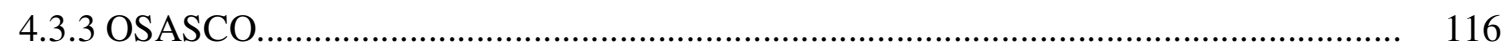
4.3.4 OCUPAÇÃO NO TRECHO OESTE DO RODOANEL APÓS O TÚNEL DE

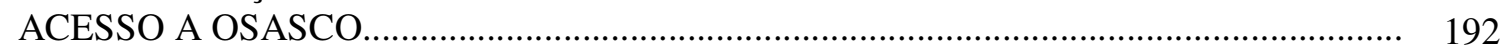
4.3.5 ANÁLISE DAS ALTERAÇÕES NA PAISAGEM URBANA NA ÁREA DE ESTUDO.

REFERENCIAS............................................................................................................... 202 


\section{INTRODUÇÃO}

As propostas de ordenamento são conhecidas desde as antigas civilizações, como por exemplo, nas aldeias da Mesopotâmia, em 4.000 a.C., que, de acordo com Santos (2004) apontam os primeiros registros de "planejadores profissionais", que eram autoridades religiosas preocupadas com a organização das cidades. Segundo o Dicionário Aurélio da Língua Portuguesa (FERREIRA, 1986, p. 134) planejamento é

$\mathrm{O}$ ato ou efeito de planejar; trabalho de preparação para qualquer empreendimento, segundo roteiro e métodos determinado [...] Elaboração por etapas, com bases técnicas (especialmente no campo sócio-econômico), de planos e programas com objetivos definidos, planificação.

Uma visão mais diferenciada de planejamento surgiu na década de 1950, quando nos EUA, os impactos ambientais resultantes de grandes obras estatais começaram a ser avaliados. A partir da década de 1970, estudos sobre desenvolvimento, sociedade, meio ambiente e qualidade de vida recebem mais atenção e os conceitos de planejamento urbano e ordenamento territorial passam a abranger outras preocupações que vão além do crescimento econômico. Segundo Santos (2004, p.24)

O planejamento é um processo contínuo que envolve a coleta, organização e análise sistematizada das informações, por meio de procedimentos e métodos, para chegar a decisões ou a escolhas acerca das melhores alternativas para o aproveitamento dos recursos disponíveis.

Em 1972, na Conferência das Nações Unidas em Estocolmo, na Suécia, houve um marco nas tomadas de decisões sobre planejamento, que já se relacionava com o meio ambiente nos países desenvolvidos, começa-se a considerar também assuntos como crescimento populacional e consumo. Como conclusão, na década de 1980, já se sabia que o desenvolvimento econômico e o meio ambiente não poderiam ser desvinculados, e isso fez com que o conceito de planejamento evoluísse, sendo associado o planejamento ambiental ao planejamento urbano.

Muitas decisões realizadas na Conferência das Nações Unidas em 1972 não alcançaram os países subdesenvolvidos, mesmo sendo um assunto que já estava em discussão. Foi na década de 1990, quando aconteceu no Brasil a Conferência das Nações Unidas sobre 
Meio Ambiente e Desenvolvimento no Rio de Janeiro (Conferência Rio-92) ${ }^{1}$, que se intensificou o debate sobre um novo modelo de desenvolvimento, envolvendo consumo, meio ambiente e extração de recursos naturais. Tanto a Conferência das Nações Unidas em 1972, como a Conferência Rio-92, foram dois importantes marcos para o planejamento urbano, visto que busca vincular conceitos de desenvolvimento com a temática ambiental.

No Brasil, após a Conferência Rio-92, ocorreram algumas mudanças e esforços nas políticas públicas urbanas com relação ao planejamento, mas em decorrência da legislação ambiental e planos diretores muitas vezes não possuírem diretrizes voltadas ao planejamento ambiental, muitas ações não surtiram os efeitos esperados. Segundo Santos (2004, p.20), "quando se planeja sob este prisma, as diretrizes, propostas ou medidas não condizem, de forma geral, com a verdade política, tecnológica e financeira da região.” A autora afirma que falar sobre qualidade de vida e igualdade social, soa, no mínimo, confuso e inexequíivel diante das realidades globais e regionais vigentes. Por isso, documentos foram criados na tentativa de auxiliar políticas públicas segundo a realidade da região ou município onde se pretende realizar um planejamento. É o caso dos Planos Diretores Municipais - PDM, que são documentos exigidos pelo Governo Federal desde 2005 que contêm normas e diretrizes de planejamento para os municípios, com o objetivo de ordenar o crescimento e promover o desenvolvimento municipal, sem causar prejuízos ambientais e sociais. O PDM deve possuir diretrizes sócio-ambientais inseridas na realidade do município para que o planejamento seja condizente com suas particularidades.

O planejamento sócio-ambiental é parte do planejamento urbano das cidades, e no caso de metrópoles como a cidade de São Paulo, torna-se mais complexo devido à dificuldade de implantação de projetos nas políticas públicas vigentes e fiscalização. Mesmo os processos de coleta, análise e organização de dados tornam-se mais dificultosos em metrópoles e regiões metropolitanas devido à extensão territorial, por isso é recomendada uma fragmentação do espaço e das informações.

Gerardi e Silva (1981, p.3) entendem por Geografia, "de forma ampla e dentro do variado quadro conceitual disponível, a área do conhecimento que se preocupa com a análise espacial." Como a geografia pode ser definida sendo "a ciência que estuda as relações entre a sociedade e a natureza, ou melhor, a forma como a sociedade organiza o espaço terrestre,

\footnotetext{
${ }^{1}$ No evento Rio-92 foi elaborado um documento chamado "Agenda 21 " que previa novas ações dos países envolvidos com relação ao meio ambiente, consumo e desenvolvimento. Documento disponível em: http://www.mma.gov.br/port/se/agen21. Acesso em 21 jul 2007.
} 
visando melhor explorar e dispor dos recursos da natureza" (ANDRADE, 1987, p.14), é por meio da ciência geográfica que surge a possibilidade de se coletar e analisar dados visando subsidiar o planejamento urbano, podendo se aplicado principalmente no caso de muitas metrópoles que atualmente são cenários de desordem e degradação.

\section{JUSTIFICATIVA}

O planejamento das cidades está em grande parte relacionado à sua mobilidade, assim a implantação de elementos que possibilitem esta mobilidade é fundamental para a dinâmica urbana. Analisando parte do histórico da metrópole de São Paulo e sua região (RMSP), podese dizer que a implantação de eixos viários terrestres, desde as trilhas para a Baixada Santista na Serra do Mar no século XVIII até a implantação dos eixos ferroviários e, posteriormente, o rodoviário, foi fator relevante para o crescimento econômico e para a expansão da área urbana na cidade de São Paulo e sua região, pois foram desencadeadas mudanças significativas na dinâmica e na paisagem urbana. Muitas vezes, tais mudanças vão além da construção e implantação dos eixos viários, relacionando-se diretamente com as características da relação do homem com o espaço e o momento histórico em que ele vive. Quando esta relação passa a acontecer de forma irregular e especulativa, pode resultar em problemas de ordem ambiental, econômica e social para a cidade.

No estado de São Paulo e sua capital, os eixos viários que interligam cidades, muitas vezes são responsáveis por transformações da paisagem urbana em seu entorno, pois podem ser indutores da expansão urbana, dependendo também de fatores como processo histórico, incentivos fiscais e acessibilidade. Quando os eixos viários interligam outros eixos de intenso movimento, como o caso do trecho oeste do Rodoanel Mario Covas na RMSP, que une várias rodovias, são necessários estudos mais aprofundados capazes de afirmar se são considerados elementos de transformação, incentivando ou impedindo a expansão urbana.

Os objetivos da pesquisa foram traçados de acordo com a problemática levantada sobre as transformações que a implantação de um eixo viário pode trazer para seu entorno. A partir daí, a rodovia escolhida para ser estudada foi o trecho oeste do Rodoanel Mario Covas na RMSP por se tratar de uma rodovia ainda com resultados recentes de sua implantação, localizada numa região metropolitana, por ser uma rodovia classe 0 , isto é, sem possibilidade de acesso às áreas lindeiras, e por se tratar de uma rodovia não radial, diferente dos principais 
eixos viários da RMSP. Dessa forma, são necessários estudos detalhados com o objetivo de caracterizar os efeitos de sua implantação no que diz respeito ao uso e ocupação do solo e a transformação que tais efeitos podem ocasionar na paisagem urbana em seu entorno.

\section{OBJETIVO GERAL}

O objetivo do presente trabalho é analisar como o eixo viário Rodoanel Mario Covas trecho oeste, iniciando no bairro de Perus, indo até o túnel de acesso ao município de Osasco, interfere no uso e ocupação do solo e quais são as transformações da paisagem urbana em seu entorno.

\section{Objetivos específicos}

Os objetivos específicos do trabalho são:

- Realizar uma análise temporal do uso e ocupação do solo nos anos de 1994 e 2002 por meio de produtos de sensoriamento remoto e banco de dados em ambiente SIG;

- Aplicar técnicas de classificação digital (analógica e automática) para mapeamento;

- Realizar análise quantitativa do uso e ocupação do solo de 1994 a 2002 para verificar as transformações ocorridas;

- Realizar uma análise qualitativa nos anos de 1984, 1994, 2002, 2006, 2007, 2008 e 2009 por meio de diferentes fontes: cartas topográficas, produtos de sensoriamento remoto, trabalhos de campo, revisão bibliográfica e análise de documentos públicos;

- Elaborar mapas temáticos que representem o uso e ocupação do solo e a transformação ocorrida do ano de 1994 ao ano de 2002;

- Analisar os resultados quantitativos e qualitativos e relacioná-los com a transformação da paisagem urbana no entorno do trecho oeste do Rodoanel Mario Covas nos bairros Perus e Jaraguá na cidade de São Paulo. 


\section{CAPÍTULO 1. BASES TEÓRICAS E CONCEITUAIS}

\subsection{Discussões sobre a paisagem urbana}

O termo paisagem ainda é muito impreciso, por isso é muito estudado por pesquisadores de diversas áreas em busca de definições. Segundo Martinelli e Pedrotti (2001, p.42) foi a pintura renascentista que deu início ao vislumbre da paisagem como objeto de estudo, dando um significado de totalidade, uma busca de forma de conjunto de âmbito mais naturalístico. A pintura renascentista, desenvolvida no século XV, buscava a descrição da realidade, geralmente em um contexto religioso, os artistas reproduziam pessoas, rostos, movimentos, a fauna e a flora a partir da observação ao seu redor e, a partir desta época, começava-se a observar o mundo e não apenas admirá-lo. Entretanto, foi só no século XIX com Darwin, que a natureza ganhou história, abandonando a concepção metafísica e mecanicista, aceitando assim que tudo o que acontece nela se dá de modo dialético, nada existindo sem movimento. Nesta época, os artistas buscaram pela representação da paisagem expressando por meio da pintura a natureza e seu movimento.

A utilização do termo paisagem é muito comum em outras áreas e em diversas formas de se expressar. O cientista e geógrafo Alexander von Humboldt ainda no século XVIII, estudou a paisagem a partir de suas explorações científicas e observações do espaço terrestre.

O pesquisador Carl Troll, já na década de 1960, foi um dos responsáveis por impulsionar pesquisas na área, tendo forte influência na geografia humana e em disciplinas relacionadas com planejamento territorial, por desenvolver uma abordagem ecológica às unidades (ecótopos) que são comparáveis ao ecossistema. Numa abordagem geográfica Troll (1971) diz que a noção básica de paisagem é a espacialidade, a heterogeneidade do espaço onde o homem habita.

Alguns autores como Cavalcanti e Viadana (2007), Rodriguez, Silva e Cavalcanti (2004), Bertrand (1971), Boesch e Carol (1968), Ab’Saber (2003) trabalham métodos científicos de análises da paisagem. 
Para Metzger (2001, p.1)

São duas as abordagens sobre a ecologia da paisagem: uma geográfica, que privilegia o estudo da influência do homem sobre a paisagem e a gestão do território; e outra ecológica, que enfatiza a importância do contexto espacial sobre os processos ecológicos, e a importância destas relações em termos de conservação biológica. Estas abordagens apresentam conceitos e definições distintas e por vezes conflitantes, que dificultam a concepção de um arcabouço teórico comum.

A definição de paisagem, na maioria das vezes, principalmente no senso comum, é entendida como uma questão estética e visual. No Dicionário Aurélio de Língua Portuguesa (FERREIRA, 1986, p.1.247), a paisagem é definida como "um espaço de terreno que se abrange num lance de vista". O autor Santos (1999), numa abordagem também visual sobre o termo, afirma que "a paisagem toma escalas diferentes e assoma diversamente aos nossos olhos ao elevarmos nosso campo de visão". O autor Metzger (2001, p.2), considerando os objetivos do observador, afirma que

A paisagem como noção de 'espaço', ganhando sentido ou utilidade através do 'olho' ou da 'percepção' de um observador, pode ser o conceito principal de confluência dessas diferentes 'visões' [...] por ser uma unidade visual, a paisagem não pode ser definida de forma universal, sem considerar a lente ou o filtro do observador.

Segundo Martinelli e Pedrotti (2001, p.40), “o campo de percepção varia muito conforme a posição do observador e a configuração morfoestrutural do terreno e respectivo arranjo de seus volumes, proporcionando uma grande diversidade às suas imagens". Para Maciel (2001, p.2), "as descrições e análises partiam do pressuposto de que através da aparência seria possível revelar o sentido das relações entre o homem e a natureza, as quais estruturariam o espaço. A descrição, portanto, conduziria à explicação.”

Os autores De Angelis e De Angelis Neto (1998) abordam a beleza cênica quando falam em paisagem e ressaltam a importância da visão que os portugueses tiveram quando chegaram ao Brasil. "Sem dúvida, foram determinantes as condições da paisagem local para que o empreendimento português tivesse êxito. Fosse a costa brasileira um inóspito deserto, certamente tal descoberta teria outros desdobramentos..." (p.538). Já o termo paisagismo, segundo Maximiano (2004, p.85) consiste principalmente em uma representação gráfica da paisagem. De Angelis e De Angelis Neto (1998) trabalham também o lado emocional 
fortemente associado à paisagem, onde existe a busca das pessoas pelo natural, por algo inusitado.

A beleza cênica, via vegetação, quando elaborada, ou mesmo em seu estado natural, cria no indivíduo um momento de magia e êxtase, que o levará a registrar, não somente através de uma câmera fotográfica, mas sobretudo a registrar na memória, a emoção do momento. (1998.,p.539)

Para Maciel (2001, p.1)

Para compreender as formas que são reveladas através da observação, o geógrafo deve reunir, comparar e decifrar os padrões espaciais constatados, buscando analisar a localização dos elementos, a teia das relações que os unem e os processos que os ensejam e alteram. Desta maneira, os elementos da paisagem não são vistos como formas separadas, mas em íntimo e dinâmico inter-relacionamento.

Além das questões visuais e estéticas salientadas, a relação do homem com o espaço também é trabalhada por diversos autores de forma a conhecer esta relação, em busca de definições. Para Monteiro (2000, p.39)

A paisagem é entendida como uma entidade espacial delimitada segundo um nível de resolução do geógrafo (pesquisador) a partir dos objetivos centrais de análise, de qualquer modo, sempre resultante da integração dinâmica, portanto instável, dos elementos de suporte e cobertura (físicos, biológicos e antrópicos) expressos em partes delimitáveis infinitamente, mas individualizados através das relações entre elas que organizam um todo complexo (sistema), verdadeiro conjunto solidário e único, em perpétua evolução.

Partindo de tais definições, busca-se um aprofundamento na análise das relações dos diversos elementos do espaço, de acordo com os conhecimentos e objetivos do observador. Segundo Santos (1999)

A paisagem é o conjunto de formas que, num dado momento, exprimem as heranças que representam as sucessivas relações localizadas entre o homem e a natureza. [...] é o conjunto de elementos naturais e artificiais que fisicamente caracterizam a área. A rigor, a paisagem é apenas a porção da configuração territorial que é possível abarcar com a visão. 
Segundo Maciel (2001, p.1)

[...] considerando, em acréscimo, a consciência da humanidade e a história, a paisagem sempre foi feita de singularidades culturais, de representações únicas dadas pelas perspectivas de subjetividade e das sensibilidades sociais.

O autor ainda afirma que

A paisagem é, em essência, uma forma da Terra cujos processos de modelagem são físicos e culturais em um só tempo, possuindo uma identidade calcada em uma constituição reconhecível, limites e relações com outros lugares num contexto maior. (p.4).

Ainda neste sentido, considerando a paisagem marcas resultantes de momentos históricos, Vitte (2007, p.77) afirma que

A geração da paisagem é resultado imediato da intencionalidade humana na superfície terrestre. Seja ontem ou hoje, por meio dos mais variados meios técnicos e científicos, a sociedade imprime sua marca no espaço que fica registrada na paisagem. Assim, a paisagem é uma representação do espaço.

Para Vitte (2007), o termo paisagem encerra uma conotação espacial, podendo ser caracterizada historicamente sob duas perspectivas: estética-fenomenológica, a qual corresponde a uma aparência, uma representação; outra caracterizada como geopolítica, designando uma unidade territorial onde se desenvolve a vida das comunidades humanas.

[...] a paisagem emerge na análise geográfica carregada de simbolismo, sendo responsável pela constituição do imaginário social que atua na condução da ação dos atores sociais, ao mesmo tempo em que mediatiza a representação do território por estes mesmos atores (VITTE, 2007, p.71) [...] a concepção de estrutura territorial efetivou-se quando ocorreu a definição de paisagem geográfica, compreendida como sendo o produto da interação entre o georelevo e as paisagens naturais como produtos da ação humana na superfície - as paisagens culturais. (p.75)

Para Metzger (2001, p.3) a paisagem é integradora de ciências sociais (sociologia, geografia humana), geofísicas (geografia física, geologia, geomorfologia) e biológicas (ecologia, fitossociologia, biogeografia), visando, em particular, a compreensão global da paisagem (essencialmente "cultural”) e o ordenamento territorial. Ab'Saber (2003, p.9) diz que a paisagem é sempre uma herança, em todo sentido da palavra: herança de processos fisiográficos e biológicos, e patrimônio coletivo dos povos que, historicamente, as herdaram 
como território de atuação de suas comunidades. O autor compreende a paisagem como o resultado de relações de processos passados e atuais.

Para Martinelli e Pedrotti (2001), a paisagem é um processo de transformação inscrito na história. Segundo os autores, no espaço completam-se coexistências de temporalidades diferentes. A categoria espacial e, concomitantemente temporal, estaria inserida numa seqüência hierarquizada de escalas temporo-espacial. Segundo Venturi (2006, p.9)

A paisagem pode ser também compreendida como um aspecto do mundo real que tem valor por si mesmo, já que pode oferecer satisfação estética, recreacional, espiritual ou ainda ser objeto para fins educacionais e científicos. Trata-se de uma categoria geográfica, compreendida como uma resultante da interação entre componentes físicos, biológicos e sociais, cuja dinâmica evolutiva envolve, portanto, matérias, energias e valores.

Para Bertrand (1971), a ação do homem deve ser considerada na paisagem contribuindo em sua formação.

A paisagem não é a simples adição de elementos geográficos disparatados. É uma determinada porção do espaço resultante de uma combinação dinâmica, portanto instável, de elementos físicos, biológicos e antrópicos que reagindo dialeticamente uns sobre os outros, fazem da paisagem, um elemento único e indissociável, em perpétua evolução (BERTRAND, 1971).

Seguindo as definições de Bertrand (1971), Monteiro (2000), Metzger (2001), Venturi (2006) e Maciel (2001), pode-se dizer que a citação de Martinelli e Pedrotti (2001, p.41) é capaz de descrever a paisagem da seguinte forma:

Qualquer paisagem, por mais simples que seja, é sempre social e natural, subjetiva e objetiva, espacial e temporal, produção material e cultural, real e simbólica. Para sua completa apreensão, não basta a análise separada de seus elementos. É preciso compreender sua complexidade, que é dada pela forma, estrutura e funcionalidade.

Os autores afirmam que não se trata apenas de uma paisagem essencialmente natural, mas integradora, global, em sua totalidade, junto aos objetos e ações, ao mundo em movimento.

Outra complexidade é o que diz respeito à escala, isto é, a paisagem pode abranger desde alguns metros até centenas de quilômetros, sendo que cada escala possui aplicabilidade distinta. A escala da paisagem deve ser definida de acordo com o que o observador deseja, isto é, uma porção do espaço que o homem é capaz de visualizar e trabalhar para alcançar 
seus objetivos. Para tanto, muito autores buscaram organizar as unidades de escalas por meio da hierarquização como Bertrand (1971) que trabalha a questão da escala por meio da divisão da paisagem em unidades tempôro-espaciais: Superior (Zona, Domínio, Região) e; Inferior (Geossistema, Geofácie e Geótopo). Os elementos climáticos e estruturais são básicos nas unidades superiores e os elementos biogeográficos e antrópicos, nas unidades inferiores. Neste escopo, não se trata somente da paisagem "natural", mas de uma paisagem que integra todas as implicações das ações antrópicas e suas interações com elementos físicos e biológicos. Sotchava (1976) divide os geossistemas em escala local ou topológica, escala regional e planetária. São divididos por hierarquia de acordo com sua estrutura; Christofoletti (1999) afirma que os geossistemas representam uma organização espacial, resultante da interação dos elementos físicos das natureza.

O autor Troppmair (1995, p.126), que também estuda a paisagem como integração de elementos, afirma que "os arranjos dos elementos do meio natural formam um mosaico que é a própria organização do espaço geográfico." $\mathrm{Na}$ busca pelo entendimento do espaço geográfico, salienta-se as definições de Santos (1988, p.26) que considera o espaço como "um conjunto indissociável de que participam de um lado, certo arranjo de objetos geográficos, objetos naturais e objetos sociais, e, de outro, a vida que os preenche e os anima, ou seja, a sociedade em movimento".

Os geógrafos alemães utilizam o termo "landschaft" para designar o objetivo da geografia. Segundo Tricart (1981), para os geógrafos alemães, a paisagem é composta por vários elementos como relevo, solo e vegetação. Para o autor, a paisagem é "uma porção perceptível a um observador onde se inscreve uma combinação de fatos visíveis e invisíveis e interações, as quais, num dado momento, não percebemos senão o resultado global”.

Os autores Boesch e Carol (1968, p.27) definem paisagem como "uma unidade espacial, com caráter definido, em entidades reais que não pode ser mais subdividida sem perder suas propriedades."

Muitos geógrafos entendem a paisagem como áreas homogêneas e, na maioria das vezes, naturais. Para Hettner apud Boech e Carol (1968, p.27), “frequentemente os geógrafos estudam a paisagem natural, não como ela foi antes da chegada do homem, mas como seria hoje se o homem não interferisse". Para tal, são necessários estudos retrocedentes no tempo para entender como seria a paisagem aproximada da realidade atual, sem a presença e interferência antrópica. 
Analisando as definições pesquisadas do termo paisagem e descritas pelos autores citados, pode-se dizer que trata-se da complexa relação entre elementos físicos, biológicos e antrópicos que modelam e caracterizam o espaço em determinado intervalo de tempo. Dessa forma, pode-se entendê-la como o resultado das interações entre diversos elementos que compõem o espaço em um dado momento.

O homem, como ser histórico e geográfico, tem sua existência e experiência ambiental regidas pelas regras da discutida globalização e revolução técnicocientífica que unem e desunem diversas dimensões de tempo e espaço. A coexistência e dialética do local-regional e do indivíduo-ambiente carecem de uma compreensão humana no âmbito da ciência para ensejar um novo grau de integração do homem no ambiente que o comporta e, ao mesmo tempo, é produzido e modificado por ele. (STURZA, 2005,p.19)

Alguns autores como Rodriguez, Silva e Cavalcanti (2004), que estudam a atividade humana modificadora da paisagem, classificam a intensidade da modificação da paisagem urbana como "fortemente modificada". Isso ocorre devido à apropriação do espaço pela sociedade, pelos processos de produção e consumo, por ações sociais com a natureza. Todas estas relações compõem a cidade, definindo uma paisagem urbana que se modifica constantemente.

Segundo Santos (1985, p. 6), "os elementos do espaço seriam os seguintes: os homens, as firmas, as instituições, o chamado meio ecológico e as infra-estruturas." O autor ainda afirma que a expressão meio ecológico já o meio modificado pelo homem, cada vez mais meio técnico. Esta definição aplica-se aos espaços urbanos são formados a partir da organização das relações sociais e processos de integração. Segundo Carlos (2001,p.213), os espaços urbanos tem concretude no espaço, nos lugares onde se realiza a vida humana, envolvendo determinado emprego de tempo, que se revela como modo de uso do espaço.

A simples enumeração das funções que cabem a cada um dos elementos do espaço mostra que eles são, de certa forma, intercambiáveis e redutíveis uns aos outros. Essa intercambialidade e redutibilidade aumentam, na verdade, com o desenvolvimento histórico; é resultado da complexidade crescente de todos os níveis da vida." (SANTOS, 1985, p.7)

$\mathrm{O}$ ato de morar e se locomover gera o uso de um espaço que, em determinado intervalo de tempo, molda características tanto no meio físico, como no meio social, em uma determinada escala, delimitação e localização. A Resolução CONAMA n ${ }^{0}$ 01/86, em seu 
artigo $6^{0}$ define meio físico "o subsolo, o ar e o clima, destacando os recursos minerais, a topografia, os tipos e aptidões do solo, os corpos d'água, o regime hidrológico, as correntes marinhas, as correntes atmosféricas". Segundo Troppmair (1995, p.126) "não devemos estudar o meio físico como produto final, como objetivo único e isolado em si, mas como o meio integrado e dinâmico em que vivem, se conectam e desenvolvem suas atividades". As aptidões físicas podem ser consideradas as fragilidades e potencialidades que o meio físico apresenta para um determinado uso e ocupação. O meio físico, entendido como integrador de elementos naturais como solo, subsolo, cobertura vegetal, corpos d'água e clima é moldado no espaço transformado pela apropriação e exploração de seus recursos. Segundo Carlos (2001, p.213), "o uso se realiza por meio do corpo e de todos os sentidos humanos, e a ação humana se realiza produzindo um mundo real e concreto, delimitando e imprimindo os ‘rastros’ da civilização”. Segundo Santos (1985, p.7), “o estudo das interações entre os elementos do espaço é um dado fundamental da análise”. O autor ainda afirma que:

O que se dá é um acréscimo ao meio de novas obras dos homens, a criação de um novo meio a partir daquele que já existia: o que se costuma chamar de "natureza primeira" para contrapor a "natureza segunda". A natureza primeira, como sinônimo de "natureza natural", só existiu até o momento imediatamente anterior àquele em que o homem se transformou em homem social, através da produção social. A partir desse momento, tudo o que consideramos como natureza primeira já foi transformado (p.8).

Além da relação dos elementos no espaço e no tempo, o contexto histórico é mais um fator que deve ser considerado. Segundo Santos (1985,p.9)

Ao longo da história toda e qualquer variável se acha em evolução constante [...] a cada momento histórico cada elemento muda seu papel e a sua posição no sistema temporal e no sistema espacial e, a cada momento, o valor de cada qual deve ser tomado da sua relação com os demais elementos e com o todo.

Os elementos do espaço são constantemente submetidos a forças internas e externas que dependem do momento histórico e do espaço que eles ocupam. O autor Santos (1985) cita como exemplo a realidade demográfica sob o aspecto do crescimento natural ou das migrações no Brasil, a cada momento da história suas condições respectivas variam. Em determinado lugar, por exemplo, o processo de migração pode ter ocorrido mais intensamente que em outros e esta intensidade pode ter sido ocasionada por outros fatores (externos ou internos) e assim sucessivamente. Portanto, a relação dos elementos que caracterizam o 
espaço deve ser analisada sempre sob o prisma dos aspectos temporais, históricos e dos fragmentos espaciais, isto é, o lugar. Segundo Santos (1985, p.10)

Cada lugar atribui a cada elemento constituinte do espaço um valor particular. Em um mesmo lugar, cada elemento está sempre variando de valor, porque, de uma forma ou de outra, cada elemento do espaço - homens, firmas, instituições, meio - entra em relação com os demais, e essas relações são em grande parte ditadas pelas condições do lugar. Sua evolução conjunta num lugar ganha, destarte, características próprias, ainda que subordinada ao movimento do todo, isto é, do conjunto de lugares.

O desenho do espaço urbano deve representar o resultado da relação de seus elementos, seus aspectos históricos e temporais. Para tanto, um estudo detalhado de diversos fatores constituintes de um inventário completo do espaço a ser representado deve ser elaborado previamente. Segundo Martinelli (1991, p.9), “as representações gráficas fazem parte do sistema de sinais que o homem construiu para se comunicar com os outros". Estas representações estão presentes em mapas e cartas temáticas. Segundo o autor, "na utilização de mapas estimula-se uma operação mental; há uma interação entre o mapa, como mero produto concreto e os processos mentais do usuário" (MARTINELLI, 1991, p.38). Os mapas são vistos como veículo de comunicação, expressando as informações ao leitor de forma interativa. Segundo o autor "este processo não se limita somente à percepção imediata dos estímulos, envolve também a memória, a reflexão, a motivação e a atenção." Segundo Martinelli e Pedrotti (2001, p.41), pode-se considerar que

Os primeiros mapas das unidades de paisagem, já como resultado da produção social do espaço, foram produzidos há mais de 4.000 anos. Os grafitos dos camunos gravados no Vale Camonica, em Bedolina, norte da Itália, são um dos levantamentos mais antigos" [...] "Estes primeiros registros gráficos das experiências da humanidade, completados certamente pela comunicação oral, diziam respeito aos aspectos da natureza, porém sem história.

A representação da paisagem é feita não somente por elementos da natureza, mas também de toda ação que a modifica.

\subsection{O uso da geotecnologia na representação da paisagem urbana}

A área urbana é o espaço natural modificado e artificializado pelas ações do homem, portanto, o resultado da relação dos elementos presentes no espaço devem estar presentes na 
sua representação. O autor Santos (1999) descreve uma paisagem atualmente cientificizada, tecnicizada e um espaço informacionalizado quando se referem a ocupações cada vez mais modernizadas. Esta paisagem deve ser representada da maneira mais próxima e fiel à realidade. Segundo Martinelli e Pedrotti (2001, p.39),

Os problemas ambientais da atualidade são nitidamente sociais, pois emergem da sociedade e não da natureza. A forma como os homens se relacionam com a natureza depende do modo como se relacionam entre si, o que é determinado pelas relações sociais vigentes em certo modo de produção, em dado momento do percurso da história da sociedade humana.

A representação da paisagem urbana deve buscar a integração entre os elementos que compõem o espaço urbano. Os autores Martinelli e Pedrotti (2001), que estudam metodologia para a cartografia ambiental, afirmam que devem ser consideradas bases para a definição de uma cartografia crítica que incorpore as relações e mediações entre os componentes que perfazem a natureza e a sociedade.

Essa cartografia, ao defrontar a complexidade da realidade a ser considerada, deve também articular as diferentes maneiras de ver vários ramos científicos, cada um resolvendo uma representação específica do espaço, valendo-se de uma escala temporo-espacial adequada ao seu estudo e concepção. (MARTINELLI et al, 2001, p. 40)

Os autores, em estudo sobre a cartografia das unidades de paisagem, analisando os Bertrand (1971) e Santos (1999), afirmam que o estudo da paisagem deverá encaminhar para uma abordagem que leve em conta a sociedade que a elaborou, dentro do quadro técnicocientífico-informacional de seu modo de produção, visto na sucessão das fases da história da humanidade. Segundo Santos (2004,p.97)

As formas de uso e ocupação são identificadas (tipo de uso), espacializadas (mapa de uso), caracterizadas (pela intensidade de uso e indícios de manejo) e quantificadas (percentual de área ocupada pelo tipo). As informações sobre este tema devem descrever não só a situação atual, mas as mudanças recentes e o histórico de ocupação da área de estudo.

Uma forma de identificar, espacializar, caracterizar e quantificar o uso do solo, descrevendo a situação atual e pretérita do espaço, é por meio da coleta, manipulação e visualização dos dados. Os métodos de informações digitais, evoluídos nas últimas décadas, 
mostram-se cada vez mais eficazes para organizar e representar dados. Segundo Martinelli (1991, p.43-44)

[...] a tecnologia da informática que envolvia a automação cartográfica evoluiu para os chamados Sistemas de Informações Geográficas que constituem dispositivos automatizados para aquisição, gerenciamento, análise e apresentação dos dados que interessam ao espaço geográfico [...] A família de técnicas de sensoriamento remoto tem grande importância na geração indireta de informações acerca da realidade".

As técnicas de sensoriamento remoto vieram acrescentar agilidade e precisão na representação do meio físico e da atuação antrópica. Os autores Luchiari, Kawakubo e Morato (2005, p.34), definem sensoriamento remoto como "a técnica que permite a obtenção de informações acerca de objetos, áreas ou fenômenos (alvos) presentes na superfície terrestre, sem que haja necessidade de contato direto com os mesmos.

Os produtos de sensoriamento remoto, tanto fotografias aéreas como imagens orbitais, podem auxiliar no processo de planejamento, permitindo identificar as características e as origens dos agentes modificadores do espaço, além de permitir monitorar a intensidade e extensão das alterações provocadas pela ocupação urbana. (LOMBARDO, 1995, p. 96).

As fotografias aéreas e imagens de satélite, são capazes de mostrar de maneira instantânea, porém estática, a caracterização do espaço, cabendo ao observador extrair as informações que necessita.

A autora Niero (1977) que estudou no Brasil, em 1977, a utilização de dados orbitais LANDSAT - 1 na classificação do uso do solo urbano, diz que

Dentre os sistemas que fornecem informações úteis para o planejamento urbano, o sensoriamento remoto pode desempenhar um papel importante no estudo das cidades e nas pesquisas que visem a solução de seus problemas. Através desta técnica é possível obter uma visão sinótica da área de estudo e uma cobertura repetitiva capaz de revelar as diferentes tendências dos fenômenos urbanos.

Segundo Pancher e Freitas (2004, p.321)

As imagens obtidas por sensores remotos registram a energia oriunda de objetos da superfície observada. As imagens apresentam os elementos básicos 
de análise e interpretação, a partir dos quais se extraem informações de objetos, áreas ou fenômenos.

Para Luchiari, Kawakubo e Morato (2005, p.46) a interpretação dos produtos de sensoriamento remoto permite efetuar inúmeros mapeamentos, dentre eles, a ocupação urbana. A técnica de análise de imagens é hoje um recurso indispensável ao levantamento de componentes das paisagens.

As técnicas de geoprocessamento e SIG são utilizadas em muitos trabalhos visando fornecer subsídios ao planejamento de áreas urbanas como mostram os autores Penido, Kux e Matos (1998) e Kux (2001) que estudam a aplicação destas técnicas e instrumentos na construção civil e no planejamento de rotas viárias; Volpe, Emídio e Lombardo (2006) que aplicaram tais técnicas no mapeamento do uso do solo em uma avenida no município de Bauru (SP), caracterizando o uso e ocupação do solo no decorrer de 22 anos. Para Ho e Lee (2000,p.1)

O Sistema de Informações Geográficas (SIG) possui poderosas ferramentas para análise espacial de dados e administração da informação do solo [...] O Sistema de Informações Geográficas (SIG) é uma recente tecnologia extremamente usada na pesquisa de problemas do uso do solo. O SIG adota métodos numéricos e ferramentas de análises espaciais no delineamento do uso do solo. (Tradução da autora) ${ }^{2}$.

Um SIG é capaz de armazenar, gerenciar e manipular dados geográficos advindos de fontes como produtos cartográficos, dados numéricos e produtos de sensoriamento remoto por meio de técnicas computacionais e matemáticas, podendo assim, representar as características da paisagem urbana e a sua dinâmica por meio de análises em determinados períodos de tempo.

\footnotetext{
2 "The Geographic Information Systems (GIS) have powerful tools to the analysis of spatial data and the management of land information [...] Geographic Information System (GIS) is a novel technology widely used to survey the land use problem. The GIS adopts the numerical methods and spatial analysis tools to delineate the land use"
} 


\section{CAPITULO 2. A IMPLANTAÇÃO DOS EIXOS VIÁRIOS E A TRANSFORMAÇÃO DA PAISAGEM URBANA}

\subsection{Considerações sobre o crescimento urbano na RMSP}

No Brasil, após a independência, surgiu uma maior preocupação no sentido de interligar algumas regiões do país, pois o isolamento das regiões segundo Galvão (1996), significava um obstáculo ao desenvolvimento econômico. Em 1838, foi elaborado e proposto pelo engenheiro José Silvestre Rebelo, o "Plano Rebelo", concebido antes mesmo da implantação da ferrovia no país.

O crescimento econômico no Brasil foi resultado da união de fatores que, segundo o Santos (1981) denomina "produto urbano", sendo estes: crescimento da população (Tabela I); recursos disponíveis e empregos urbanos, sendo que cada fator exerce influência sobre o outro.

\begin{tabular}{cccc}
\hline \multicolumn{4}{c}{ Tabela I: Contagem da população brasileira } \\
\hline \multicolumn{4}{c}{$B R A S I L$} \\
\hline 1940 & População total & População urbana & Índice de urbanização \\
1950 & 41326000 & 10891000 & 26,35 \\
1960 & 51944000 & 18783000 & 36,16 \\
1970 & 70191000 & 31956000 & 45,52 \\
1980 & 93139000 & 52905000 & 56,80 \\
1991 & 119099000 & 82013000 & 68,86 \\
& 150400000 & 115700000 & 77,13 \\
\hline
\end{tabular}

Segundo dados do censo 2000 do IBGE (BRASIL, 2008), a população do Brasil no ano 2000 era de 169.799.170, sendo a população urbana de 137.953 .959 e a rural de 31.845.211. De 1940 até o ano 2000, o índice de urbanização aumentou de 26,35\% a 81,24\%, tornando o Brasil um país predominantemente urbano. No Censo de 1940 havia 1.574 municípios no Brasil, no Censo 2000 este número aumentou para 5.507 e, atualmente, são 5.565 municípios (BRASIL, 2008a).

O Brasil é um país com dimensão territorial extensa $\left(8.514 .876 \mathrm{Km}^{2}\right.$ ) (BRASIL, 2008b), algumas regiões apresentam maiores índices de urbanização e outras apresentam índices menores. A população brasileira cresceu devido a diversos fatores, entre eles movimentos migratórios internos (atração que a cidade exerce sobre outras cidades ou sobre o campo) e migração estrangeira, um dos resultados da influência do "produto urbano". 
A atração das cidades sobre o campo que ocasionou o chamado "êxodo rural" no Brasil, deve-se em grande parte ao desequilíbrio econômico entre a cidade e o campo. ${ }^{3}$ No início do século XX, houve um intenso deslocamento de pessoas para as cidades em busca de emprego, facilidade de consumo e conforto que a cidade aparentemente podia oferecer. Mas, com o decorrer do tempo, esta população de migrantes não foi inteiramente absorvida pela cidade que necessitava de mão-de-obra mais qualificada, fazendo surgir uma população excedente, desqualificada e desempregada. Segundo Lombardo (1995, p.3), com a população superior à capacidade produtiva do sistema, a demanda por empregos e serviços supera a oferta existente e, por conseqüência, a segregação social se acentua e a população desempregada busca por meios de sobreviver na cidade, marginalizando-se nela.

Atualmente, o processo de imigração para o Brasil é diferente daquele que ocorria no final do século XIX e início do século XX, quando imigrantes vinham trabalhar nas colônias agrícolas, principalmente no sudeste e sul do país. Hoje, existem os imigrantes que chegam no Brasil, principalmente na metrópole paulista, trabalhar no mercado informal, muitas vezes sob péssimas condições de trabalho, e existem também os imigrantes que se destinam aos grandes centros financeiros para o trabalho fixo ou temporário, em filiais de multinacionais ou centros de decisões.

Entre o final do século XIX e início do século XX, as ferrovias marcaram o setor de transportes e movimentaram a economia cafeeira até seu enfraquecimento ocorreu no final da década de 1920.

A construção de Estradas de Ferro no século XIX intensificou o processo de crescimento urbano, principalmente no estado de São Paulo, pois as estradas de ferro eram responsáveis por movimentar a economia cafeeira e atividades relacionadas. Nesta época, eram formadas vilas operárias que mais tarde deram origem às cidades, assim, é possível dizer que o eixo ferroviário influenciou a estrutura de muitas cidades, tendo cada uma suas particularidades. O intenso movimento emigratório europeu no final do século XIX e início do século XX com direção ao Brasil, foi também um fator relevante que impulsionou o desenvolvimento e crescimento urbano no estado de São Paulo. Segundo Santos (1981, p.74), "o momento de chegada dos imigrantes em um país pode ser fator de crescimento urbano quando ocorre em um momento econômico oportuno". No Brasil, a chegada de imigrantes

\footnotetext{
${ }^{3} \mathrm{O}$ processo de mecanização do campo através do incremento de novas tecnologias contribuiu para aumentar o desemprego no campo empurrando uma grande massa de trabalhadores para as cidades.
} 
europeus antes mesmo do impulso industrial, foi um marco importante no modelo de crescimento econômico.

Não foi criada uma rede para interligar as regiões brasileiras por meio da ferrovia e, no final da década de 1920, os projetos rodoviários começaram a receber maior importância, sendo elaboradas propostas nesta modalidade, podendo ser citado o "Fundo Especial para Conservação e Construção de Rodovias", criado em janeiro de 1927, Decreto Federal 5.141. Nesta época iniciou-se a construção das rodovias Rio - Petrópolis e Rio - São Paulo.

Na década de 1950, além do êxodo rural, o processo de urbanização se intensifica devido a projetos e propostas efetivamente implantadas durante o governo do Presidente Juscelino Kubitschek como a construção de importantes eixos viários, a abertura do país para capitais estrangeiros e a instalação de indústrias, dentre elas, a automobilística, que foi responsável por valorizar a implantação dos eixos rodoviários, principalmente no sudeste brasileiro, onde já havia sido desenvolvida a ferrovia e o crescimento urbano decorrente desta modalidade de transporte. Pode-se citar a construção da rodovia Rio - Belo Horizonte em 1957, a Ponte da Amizade ligando o Brasil ao Paraguai em 1965 e outras obras no restante do país. "Apenas após a Segunda Guerra Mundial que a integração do território se torna viável, quando as estradas de ferro, até então desconectadas na maior parte do País, são interligadas, constroem-se estradas de rodagem, pondo em contato as diversas regiões..." (SANTOS, 2005, p.38).

\subsection{A construção de eixos viários e as transformações na paisagem urbana na RMSP}

$\mathrm{Na}$ década de 60, a construção de rodovias como Anhanguera, Castelo Branco e Washington Luis foi um marco para o desenvolvimento na cidade e no estado de São Paulo, devido à expansão radial da metrópole. Muitas indústrias, que antes eram localizadas nas proximidades das ferrovias, mudaram-se para as proximidades das rodovias, usufruindo um novo sistema de transporte e das facilidades de locomoção entre as cidades do interior e a capital. Segundo Villaça (2001, p. 70)

Parece haver íntima relação entre as vias regionais de transporte e o crescimento físico das cidades. As ferrovias provocam crescimento descontínuo e fortemente nucleado, em que o núcleo ou o pólo se desenvolve junto às estações. As rodovias - especialmente as expressas - provocam um crescimento mais rarefeito e descontínuo e menos nucleado que as ferrovias. Isso se deve às diferenças de acessibilidade oferecidas pelos dois tipos de via. Na ferrovia, a 
acessibilidade só se concretiza nas estações; na rodovia pode se concretizar em qualquer ponto.

É preciso considerar que outros fatores, além da construção das rodovias, também influenciaram a mudança das indústrias da capital para a RMSP e para o interior, como: valores de terra mais acessíveis, incentivos fiscais, menores custos de mão-de-obra e legislação ambiental menos rigorosa.

Em 1964, no movimento militar, ocorre uma modernização agrícola e aumenta o consumo interno diversificado pela classe baixa, com os sistemas de créditos financeiros. Estas atividades incentivaram uma expansão no setor industrial. Segundo Santos (1981, p.41)

A cidade exerceu atração sobre a população também pelo incentivo de consumo para a classe baixa que consegue consumir além do que permite seu rendimento devido aos empréstimos, prestações e linhas de crédito. A classe média, no entanto, tende a viver a maneira das classes mais abastadas, ao menos naquilo que diz respeito a certos tipos de consumo conspícuo, como é o caso de automóveis, habitação e viagens.

Entre 1969 e 1971 houve execução de grandes obras viárias como viadutos e avenidas, obras contra enchentes com canalização de córregos e construção de avenidas em fundos de vale na cidade de São Paulo. Após a década de 1960 houve o aumento no deslocamento das indústrias para a região da metrópole. Segundo o Instituto Brasileiro de Geografia e Estatística - IBGE (BRASIL, 2004) “as regiões metropolitanas são estabelecidas por Legislação Estadual e constituídas por agrupamentos de municípios limítrofes, com o objetivo de integrar a organização, o planejamento e a execução de funções públicas de interesse comum".

A saída das indústrias do centro da metrópole se intensificou e, atualmente, a metrópole paulistana está perdendo aos poucos a característica predominantemente industrial quando se analisa um crescimento significativo no setor terciário que, por sua vez, também não consegue absorver toda população trabalhadora, pois necessita mais uma vez, de pessoas qualificadas, o que auxilia no aumento da taxa de desemprego, na formação de mercado informal e na marginalização.

Na década de 1960 e 1970 destaca-se a construção da rodovia Regis Bittencourt que liga a cidade de São Paulo a Curitiba (inaugurada em 1961); a entrega dos primeiros trechos pavimentados da rodovia Rio - Santos (atualmente com $209 \mathrm{~km}$ no estado do Rio de Janeiro e 
248 km em São Paulo); a rodovia dos Imigrantes em 1974, sendo o complexo Anchieta Imigrantes com 176 km de extensão; a rodovia dos Bandeirantes inaugurada em 1978; Na década de 1980 foi inaugurada a rodovia Ayrton Senna, unindo São Paulo a Guararema; e na década de 1990, a rodovia Carvalho Pinto que tem seu início no final da Rodovia Ayrton Senna e termina na rodovia Presidente Dutra.

No caso das rodovias Bandeirantes, Castello Branco, Imigrantes e Ayrton Senna/Carvalho Pinto são eixos viários de alta capacidade e classe 0 , isto é, rodovias fechadas e controladas que têm o objetivo de ligar pontos extremos segregando o tráfego local do fluxo de longo percurso.

Em 1998, as rodovias Anchieta, Bandeirantes, Anhanguera e Imigrantes foram desestatizadas, passando a serem administradas por empresas privadas. Em 1998 também teve início a construção do primeiro trecho do Rodoanel (trecho oeste), interligando as rodovias Régis Bittencourt, Raposo Tavares, Castelo Branco, Bandeirantes e Anhanguera, sendo finalizado em 2002, data que foi inaugurada também a segunda pista da rodovia Imigrantes. ${ }^{4}$

A união dos sistemas de transporte e a construção de eixos viários trazem mudanças significativas para uma cidade pelo fato de criarem uma rede espacial que vem suprir uma das principais necessidades no que se refere ao desenvolvimento econômico: o transporte de mercadorias, matérias-prima e serviços.

Atualmente, a proximidade de rodovias é um forte atrativo para a implantação de novos prédios e instalações industriais. $\mathrm{O}$ setor da construção civil começa a sentir os efeitos dos investimentos industriais, servindo também como um "termômetro" na análise do crescimento industrial. $\mathrm{O}$ setor cresce com os investimentos em construções industriais, sendo responsável pela efetivação da transformação da paisagem urbana, formada por grandes obras, decorrentes de uma nova demanda.

Para Blanco (2008, p.31), "os Centros de Distribuição trazem boas oportunidades. Com leis que proíbem a circulação de caminhões (e até veículos de cargas menores) nos centros das cidades do Rio de Janeiro e São Paulo, as rodovias são alvos estratégicos para criação de depósitos de mercadorias”. O presidente da Associação Brasileira da Construção Industrializada de Concreto (ABCIC) diz a Blanco (2008) em entrevista que "a cada trecho do Rodoanel anunciado há uma corrida de empresas de logística à procura de áreas”.

\footnotetext{
${ }^{4}$ ALMIRANTE, M. Memória do Transporte Público. 2007. Disponível em: http://www.rota.notlong.com. Acesso em 22 nov 2007. Fontes: Relatório do Ministério da Viação e Obras Públicas de 1937, p.11.
} 
A RMSP (Figura 1) é formada por 39 municípios e é caracterizada por um intenso processo de conurbação, expressão que refere-se a "fusão de áreas urbanas" segundo Villaça (2001, p.49). Possui aproximadamente 19.616.060 habitantes (BRASIL, 2008a) com território de $7.944 \mathrm{~km}^{2}$, sendo cerca de $2.200 \mathrm{~km}^{2}$ urbanizado (BRASIL, 2007), constituindo um dos maiores aglomerados urbanos do mundo.

A RMSP, segundo a Empresa Paulista de Planejamento Metropolitano - EMPLASA (SÃO PAULO, 2007), é o maior pólo de riqueza nacional, onde estão localizadas as sedes brasileiras dos mais importantes complexos industriais, comerciais e, principalmente, financeiros que controlam as atividades econômicas do país.

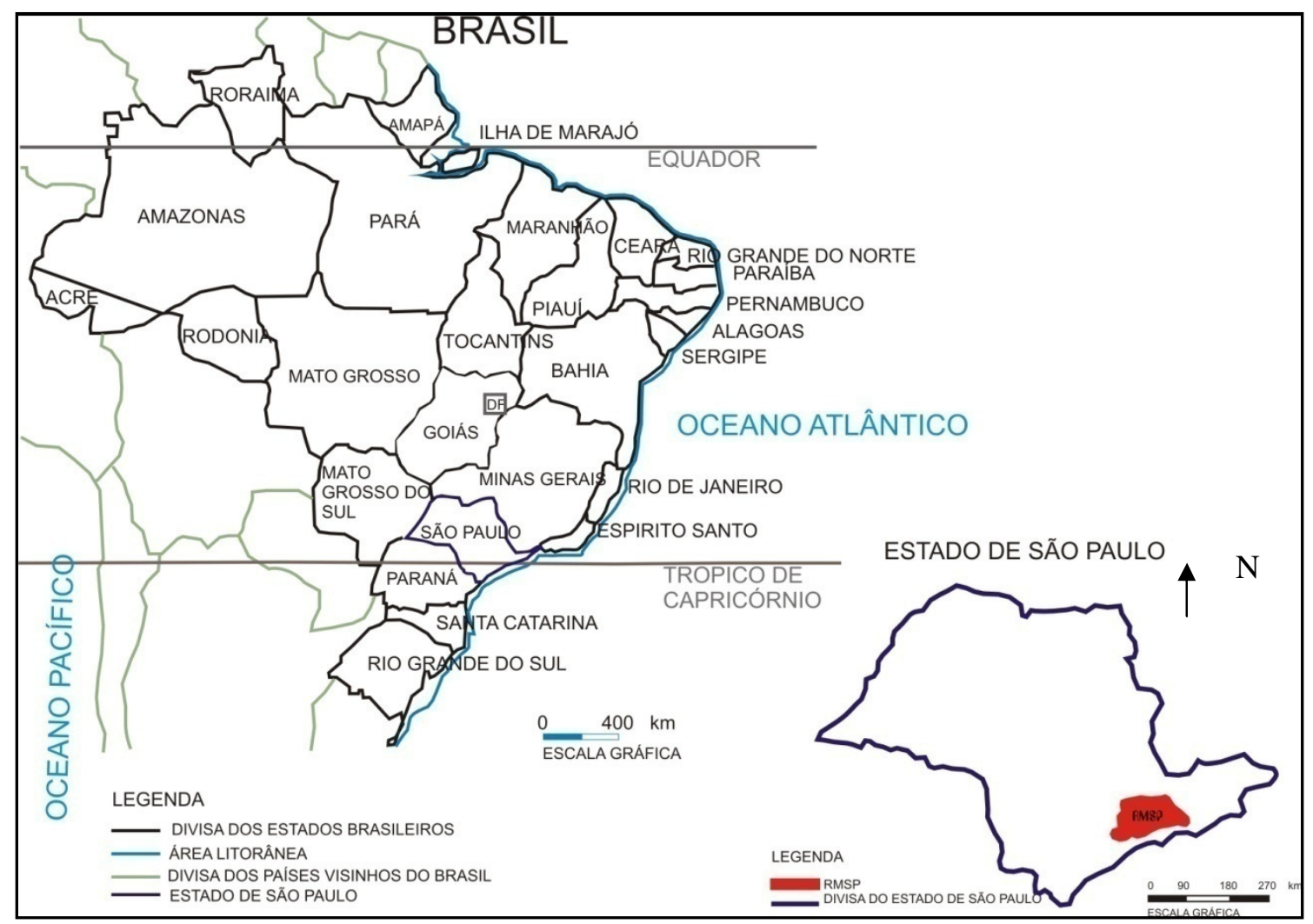

Figura 1: Localização do estado de São Paulo no Brasil e da Região Metropolitana de São Paulo (RMSP)

Fonte: IBGE. Editado por Larissa Lucciane Volpe (2007)

Segundo a EMPLASA (SÃO PAULO, 1989), a área urbanizada da RMSP cresceu à razão de 3.500 ha/ano entre 1974 e 1987. O crescimento resultou em um processo de conurbação e criou a principal área urbanizada e industrializada do país formada pelos 
municípios: Arujá, Barueri, Biritiba-Mirim, Cajamar, Caieiras, Carapicuíba, Cotia, Diadema, Embu, Embu-Guaçu, Ferraz de Vasconcelos, Francisco Morato, Franco da Rocha, Guararema, Guarulhos, Itapevi, Itaquaquecetuba, Itapecerica da Serra, Jandira, Juquitiba, Mairiporã, Mauá, Mogi das Cruzes, Osasco, Pirapora do Bom Jesus, Poá, Ribeirão Pires, Rio Grande da Serra, Salesópolis, Santa Isabel, Santana de Parnaíba, Santo André, São Bernardo do Campo, São Caetano do Sul, São Lourenço da Serra, São Paulo, Suzano, Taboão da Serra, Vargem Grande Paulista (SÃO PAULO, 2007).

Segundo a AAE (SÃO PAULO, 2004, p.44), a ocupação RMSP se deu da seguinte forma:

No início, como base para expedições dos Bandeirantes, e, posteriormente, com a agricultura, que dominou a cena até o final do século XIX. Até então, o núcleo urbano era reduzido, mas todo o entorno encontrava-se alterado pela presença humana, embora ainda esparsa, mas já com o acúmulo de séculos de alterações.

A tabela II ilustra o crescimento populacional no Brasil das décadas de 1940 a 2008.

\begin{tabular}{|c|c|c|c|c|c|}
\hline \multicolumn{7}{c}{ Tabela II: Crescimento populacional } \\
\hline & $\mathbf{1 9 4 0}$ & $\mathbf{1 9 5 0}$ & $\mathbf{1 9 6 0}$ & $\mathbf{1 9 7 0}$ & $\mathbf{1 9 8 0}$ \\
\hline RMSP & 1.568 .045 & 2.662 .786 & 4.739 .406 & 8.139 .730 & 12.578 .245 \\
\hline $\begin{array}{c}\text { Município de São } \\
\text { Paulo }\end{array}$ & 1.326 .261 & 2.198 .096 & $3.781 .446^{*}$ & $5.924 .615^{* *}$ & 8.490 .763 \\
\hline $\begin{array}{c}\text { Cidades da RMSP } \\
\text { exceto a capital }\end{array}$ & 241.784 & 464.690 & 957.960 & 2.215 .115 & 4.087 .482 \\
\hline
\end{tabular}

Fonte: Fundação SEADE. Anuário Estatístico do Estado de São Paulo 1980. São Paulo, 1981. IBGE. Estimativas preliminares do Censo Demográfico 1980.

*Inclui Osasco, criado em 18/02/1959 pela Lei n. 5825 e desmembrado do município de São Paulo. Todos os cálculos realizados até 1960 incluem Osasco no município de São Paulo

** Exclui Osasco.

\begin{tabular}{|c|c|c|c|}
\hline \multicolumn{5}{c}{ Continuação da Tabela II } \\
\hline RMSP & $\mathbf{1 9 9 1}$ & $\mathbf{2 0 0 0}$ & $\begin{array}{l}\text { Projeção para } \\
\text { julho de 2008 }\end{array}$ \\
\hline $\begin{array}{c}\text { Município de } \\
\text { São Paulo }\end{array}$ & 15.444 .941 & 17.878 .703 & 19.697 .337 \\
\hline $\begin{array}{c}\text { Cidades da RMSP } \\
\text { exceto a capital }\end{array}$ & 5.7946 .185 & 10.434 .252 & 10.940 .311 \\
\hline
\end{tabular}

Fontes: IBGE. Censos Demográficos 1991 e 2000. Disponível em: http://www.ibge.gov.br/home/ estatistica/populacao/censodem. SEADE (2008). Projeção de População Residente. Disponível em: http://www.seade.sp.gov.br/produtos/projpop/index.php 
Na década de 1970 houve um declínio na taxa de crescimento populacional na capital em relação às outras cidades da RMSP (Gráfico I).

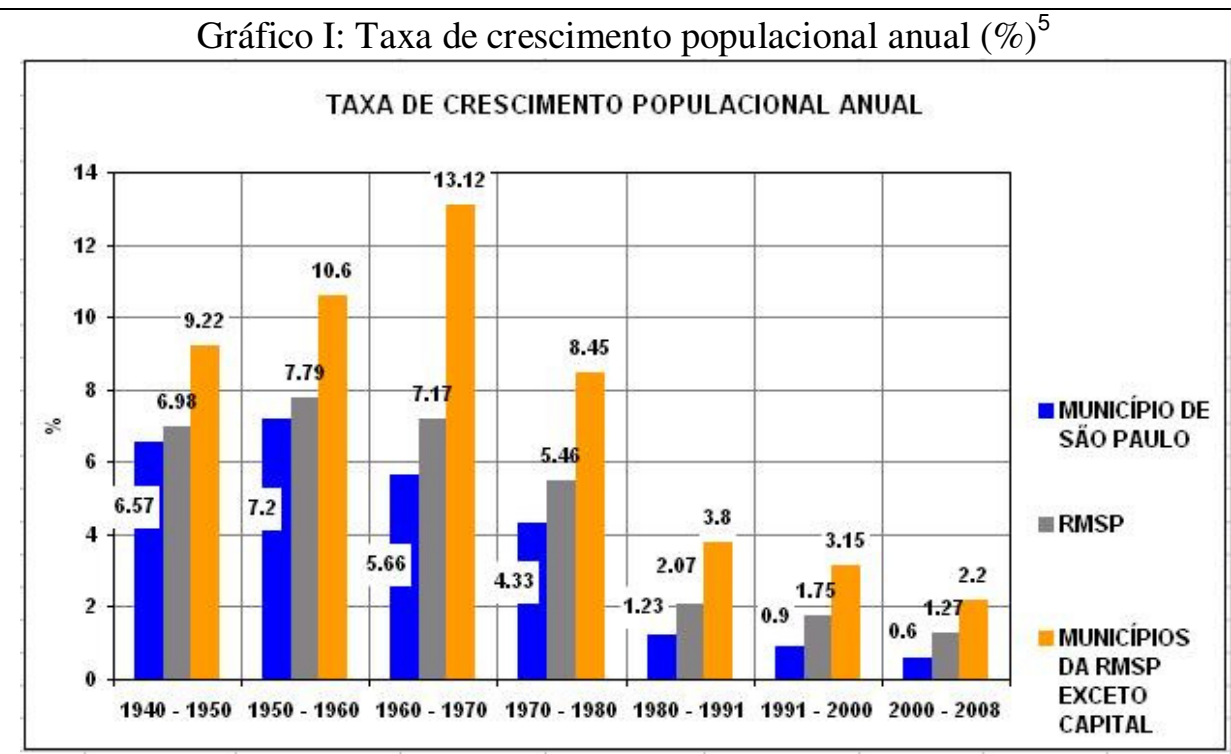

Fonte: SÃO PAULO (2007)

Dados organizados e gráfico elaborado pela autora

A descentralização industrial foi um dos fatores que contribui para a diminuição da taxa de crescimento populacional na cidade de São Paulo, pois a população desloca-se para outras cidades da região em busca de empregos e moradia. O alto valor para comprar ou alugar um imóvel na capital também faz com que as pessoas busquem na região outros lugares para morar, mas que sejam próximos a capital.

Com a implantação de importantes eixos viários no país, muitas indústrias que localizavam-se na capital paulista começaram a deslocarem-se para locais mais afastados na RMSP e também para o interior do estado, já que a construção de rodovias permitiram o fácil acesso interior - capital e vice-versa. Sendo assim, a implantação das rodovias que interligam a capital ao interior foi responsável, em grande parte, pela desconcentração industrial e pelo aumento da taxa de crescimento populacional na RMSP. Atualmente esta desconcentração e aumento populacional é responsável também por um intenso movimento nas rodovias que ligam a região à metrópole, pois muitas indústrias ainda mantêm sua matriz ou sua

\footnotetext{
${ }^{5}$ A partir de 1960, considera-se Osasco parte da RMSP, excluindo-o do município de São Paulo.
} 
administração física na metrópole, sendo as rodovias uma das formas de comunicação entre as partes.

Na década de 1980, foi fator relevante o processo migratório interno na RMSP, resultado da descentralização industrial (mudança de indústrias da capital para a região metropolitana) e do acesso entre a capital e as cidades da região.

O processo de escolha para local da moradia é influenciado não só pela condição de acessibilidade, mas também pela oferta de empregos formais e informais, propiciadas por atividades econômicas existentes no entorno, ainda mais se considerarmos que as empresas poderão estar se deslocando para a região (FAUUSP, 2005, p.53).

Em 1990, a abertura do mercado internacional e a alta competitividade ocasionada pela entrada de produtos com menores preços no país, determinou um nova estrutura de mercado no Brasil, principalmente nas metrópoles industriais. Muitas empresas buscaram por locais ainda mais afastados, como o interior paulista.

A desconcentração industrial está longe de significar um esvaziamento de indústrias na metrópole paulista, atualmente ainda caracterizada por este setor, mas com sinais de fortalecimento no setor de comércio e serviços.

A AAE (SÃO PAULO, 2004), em estudo sobre a dinâmica econômica da RMSP, ressalta alguns fatores resultantes como: a subdivisão de grandes plantas industriais em várias empresas descentralizadas que se espalharam pela malha urbana exigindo maior quantidade de viagens para transporte entre empresas, o que auxiliou a onerar as vias de transporte urbano; descentralização de empresas e indústrias para outras regiões do estado e do país, pois os custos para os empresários se manterem ou investirem na RMSP tornou-se pouco atrativo (alto custo do terreno, transporte, mão de obra etc.). A alta movimentação de produtos e a ampliação de fluxos individuais devido a localização de centros financeiros e de decisões de muitas empresas continuarem na capital, também contribuíram para aumentar o fluxo viário.

O aumento do fluxo de transporte voltado para indústrias, comércios e serviços unindo a capital com a região, o restante do estado e do país, associado a deficiência de transportes públicos para trabalhadores e moradores, ocasionou uma sobrecarga dos eixos viários.

O deslocamento de pessoas e serviços é responsável pelo movimento nas rodovias, principalmente quando a metrópole passa a ser um lugar onde se trabalha, mas não onde se 
mora. É o que ocorre com a população que busca por mais qualidade de vida no interior do estado de São Paulo, mas necessita da demanda de trabalho e serviços da capital, viajando diariamente pelas rodovias.

"Uma metrópole espraiada e dispersa significa maior tempo de deslocamento de seu habitantes, maior tráfego de veículos e maior movimento pendular entre o local de moradia e o local de trabalho”. (LENCIONI, 2008, p.10).

A construção de eixos viários também é responsável pela caracterização da fisionomia urbana e organização espacial. A abertura de eixos viários transforma a vida dos cidadãos, e este fato pode ser notado em diferentes escalas, desde a construção de uma rodovia de grande movimento, até a pavimentação das menores ruas em um bairro, adquirindo características e proporções diferentes. O entorno dos eixos viários é alterado conforme as características locais e de acordo com as necessidades da população. A construção de uma rua, por exemplo, pode incentivar a implantação de projetos de iluminação, arborização. A abertura de uma nova avenida na cidade pode incentivar a instalação de novas áreas de serviços e comércios. A construção de uma rodovia pode incentivar a implantação de loteamentos residenciais, empreendimentos industriais e empresariais.

O estudo dos fatores de expansão econômica urbana deve levar em conta os investimentos regionais, o movimento dos capitais em grande escala e o papel dos transportes que fazem com que, de um lado, as cidades percam seu isolamento e de outro facilitem as trocas com a região, o conjunto do país e mesmo estrangeiro (SANTOS, 1981,p.67).

Um exemplo da influência dos eixos viários no crescimento urbano das cidades foi na área urbana de São Paulo, que começou a se expandir com a abertura de ruas e parques públicos já na primeira metade do século XIX, a partir do surgimento dos primeiros transportes coletivos (bondes). A construção da Avenida Paulista também foi um importante marco no crescimento da cidade, ampliação de eixos viários, instalação e melhoria de infraestrutura, e incentivou o surgimento dos primeiros prédios.

Analisando mais detalhadamente, é possível observar na cidade de São Paulo, ainda no século XIX, por exemplo, um significativo crescimento com a abertura de avenidas, como a Avenida Paulista em 1891, e a construção de viadutos como o Viaduto do Chá em 1892, 
sendo de extrema relevância na época por interligar o "centro velho" a "cidade nova" (Fotos 1 e 2$)^{6}$.

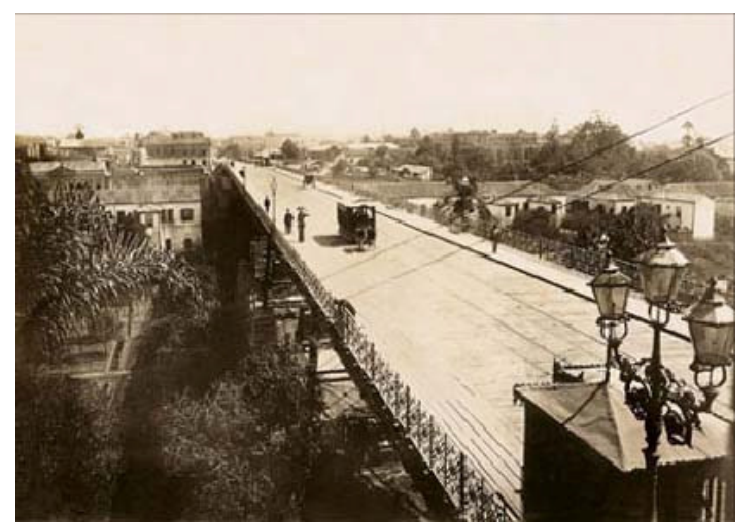

Foto 1: Viaduto do Chá (1892)

Foto: Autor desconhecido

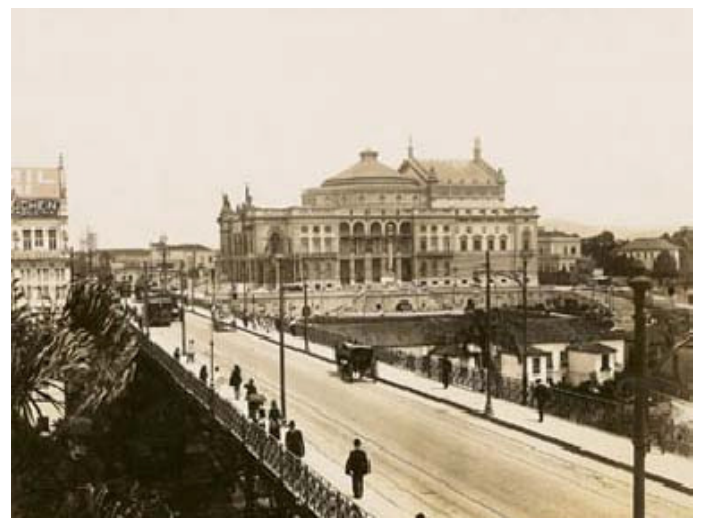

Foto 2: Viaduto do Chá (1914)

Foto: Aurélio Becherini

A paisagem urbana da cidade de São Paulo começou a se configurar baseada nas vilas de trabalhadores, no início do século $\mathrm{XX}$, que mais tarde se transformaram em pequenos centros.

A urbanização desenvolvida com o advento do capitalismo aparece na Europa como fato moderno logo depois da revolução industrial. Mais recentemente e paralelamente à modernização ela se generaliza nos países subdesenvolvidos; por isso, costuma-se associar a idéia de urbanização à de industrialização (SANTOS, 1981, p.3)

A partir dos anos 50, desencadeou-se uma acelerada implantação de rodovias, começando com a Anchieta, para substituir e aumentar a capacidade da antiga Estrada Caminho do Mar, e a Presidente Dutra, para melhorar e aumentar a capacidade da Estrada Velha Rio - São Paulo. Depois, foi a Anhangüera, em substituição à Estrada Velha de Campinas. Na região de Sorocaba, o acesso recorria à rodovia Raposo Tavares. Para o Sul, segue a Régis Bittencourt. Para o norte, através da Fernão Dias. Com esses eixos viários e outros menos expressivos, abertos ao seu entorno, aconteceu a expansão radial da metrópole (SÃO PAULO, 2004, p.44-45).

A ocupação e o crescimento da periferia da cidade de São Paulo e da região metropolitana é um fator relevante, pois, se por um lado, induziu pequenos empregos na periferia, por outro lado, a maioria dos empregos continuam na área central, o que força os trabalhadores a viajarem pelas rodovias e dependerem de transportes e vias de acesso de intensa movimentação diariamente. Segundo Barbon (2004), a ocupação residencial pode

\footnotetext{
${ }^{6}$ Texto baseado em: Jornal Brasileiro de Cultura por Nelly Martins Ferreira Candeias. Disponível em http://www.jbcultura.com.br/nelly/tmunicipal.htm. Acesso em 23 de jul de 2007. Artigo publicado na Revista da Academia Lusíada de Ciências, Letras e Artes, nº19/20, p. 340-46. São Paulo, 2003.
} 
estar relacionada com a rarefação da ocupação residencial em áreas centrais. Segundo a autora, algumas ações políticas com relação ao provimento de moradias a famílias, e mesmo o financiamento de casas próprias, também impulsionam movimentos migratórios. "É provável que quanto menor a renda maiores sejam os raios de deslocamento da população, o que também favoreceria essa expansão da mancha urbana" (p.3).

A localização de ocupações residenciais no entorno dos eixos viários ainda mostra a forte ligação com a capital. Segundo a empresa DERSA

[...] embora o assentamento populacional na periferia tenha gerado um certo contingente de empregos induzidos, correspondente ao terciário tipicamente local (pequeno comércio, serviços locais, etc), o grosso dos empregos na RMSP permaneceu nas áreas centrais consolidadas. Se os empregos ficam no centro e a população vai para a periferia é óbvio que aumentam a quantidade e a extensão dos deslocamentos residência-trabalho, a causa mais importante das viagens. Ao se relembrar que isso está ocorrendo em uma das mais populosas cidades do mundo fica nítida a dimensão do desafio crescente, quiçá inalcançável, que se coloca para o sistema de transporte urbano (SÃO PAULO, 2005,p.3).

A predominância dos vínculos empregatícios nos municípios por onde passa o Rodoanel é o setor de serviços, segundo SEADE (2007). No que se refere ao setor industrial, na RMSP, os municípios de São Paulo (bairros Perus e Jaraguá), Barueri e Carapicuíba ocupam as últimas posições. A frente estão os municípios de Cotia, Embu, Osasco e Santana de Parnaíba (Gráfico II). São muitos os fatores que interferem nestas posições, como foi visto anteriormente, cada município contém suas características, seu histórico e incentivos, criando assim, particularidades que incentivam ou desmotivam o crescimento em determinado setor. 


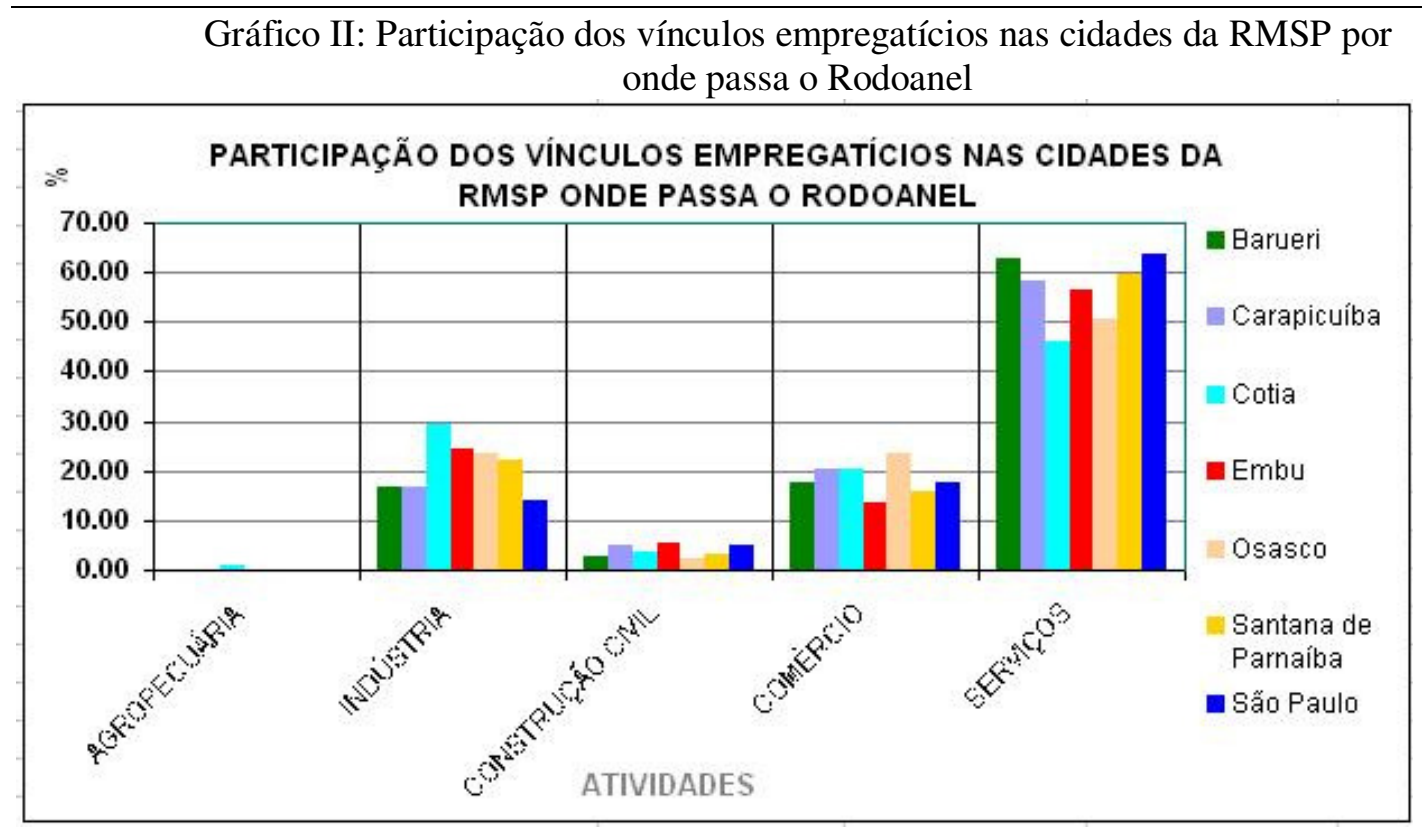

Fonte: Perfil Municipal. Sistema Fundação Estadual de Análise de Dados - SEADE (2007). Disponível em: http://www.seade.gov.br/produtos/perfil/perfil.php

Dados e gráfico organizado pela autora

No trecho do Rodoanel que segue após o túnel de acesso a Osasco até seu final no município de Embu, a predominância é de áreas industriais, principalmente nas proximidades das rodovias Castello Branco e Raposo Tavares, como é relatado no relatório FAUUSP (2005, p.139-140).

[...] parece ficar claro que a valorização e a indução à ocupação será verdadeiramente significativa nos entroncamentos, e provavelmente em um raio não desprezível de seu entorno. E especialmente no caso do Trecho Oeste, a somatória desses 'entornos' pode abranger quase toda a rodovia pela proximidade dos acessos existentes. (FAUUSP, 2005, p.86-87)

"A melhoria e proliferação das vias de acesso aliada aos incentivos fiscais, entre outros fatores, estimularam a migração de novas empresas e profissionais para a região." (REVISTA VIVA SÃO PAULO, 2006) ${ }^{7}$.

Pode-se citar as indústrias Natura, a Good Year e a Gerdau, instaladas em 2006 nas proximidades do trecho oeste do Rodoanel Mário Covas e da rodovia Castello Branco. As

\footnotetext{
${ }^{7}$ Especial Mercado Imobiliário 2006. Revista Viva São Paulo. 2006. Disponível em: http://vivasaopaulo.as1.com.br/mostra_noticia.php?id=1155
} 
ocupações empresariais e novas áreas industriais no entorno do Rodoanel são relevantes principalmente no município de Cotia, Embu e Osasco.

O município de Osasco, segundo dados da Fundação Sistema Estadual de Análise de Dados - SEADE (BRASIL, 2007), é a $5^{\circ}$ maior cidade do estado de São Paulo. A população é de 701.012 habitantes segundo população estimada pelo IBGE (BRASIL, 2007) e a área, completamente urbana, é de aproximadamente $65 \mathrm{~km}^{2}$. A expansão de Osasco ocorreu principalmente após a construção da Estrada de Ferro pela Estrada de Ferro Sorocabana - EFS (Foto 3) no final da década de 1920 com o surgimento do bairro Quitaúna.



A demanda de passageiros na estação aumentou principalmente após a instalação do Quartel do Exército Brasileiro nas proximidades na década de 1940. O município conseguiu sua emancipação em 1962, tornando-se município independente de São Paulo. A Fepasa reconstruiu a estação e a reinaugurou no final da década de 1970; e em 1996 a linha passa a ser da CPTM. O bairro Quitaúna cresceu nas proximidades da estação ferroviária, assim como ocorreu em muitos municípios brasileiros durante a trajetória da história da ferrovia. A área foi densamente ocupada por residências, comércios e galpões industriais.

A industrialização em Osasco teve início no começo do século XX com a instalação de grandes empresas como a Hervy em 1912, a Continental Products em 1915 e a Cotonifício Beltrano em 1923. Observa-se assim que Osasco, juntamente com a cidade de São Paulo, está entre as cidades onde o processo de industrialização ocorreu primeiro no estado de São Paulo.

O município de Osasco foi favorecido pela proximidade da cidade de São Paulo e a facilidade de deslocamento de produtos e serviços trazida pelas rodovias Anhanguera, Castelo Branco e Raposo Tavares, construídas décadas antes do Rodoanel Mario Covas. 


\subsection{Características do trecho oeste do Rodoanel Mario Covas}

No que se refere às áreas de matas, o trecho oeste do Rodoanel antes do túnel de acesso a Osasco (trecho 1) mostra-se ainda com alguns fragmentos de mata mais densos devido ao Parque do Pico do Jaraguá e a área de preservação no "Morro de Jesus". Já o trecho oeste após o túnel de acesso a Osasco (trecho 2) mostra-se densamente ocupado, sem fragmentos de mata (Figura 2).

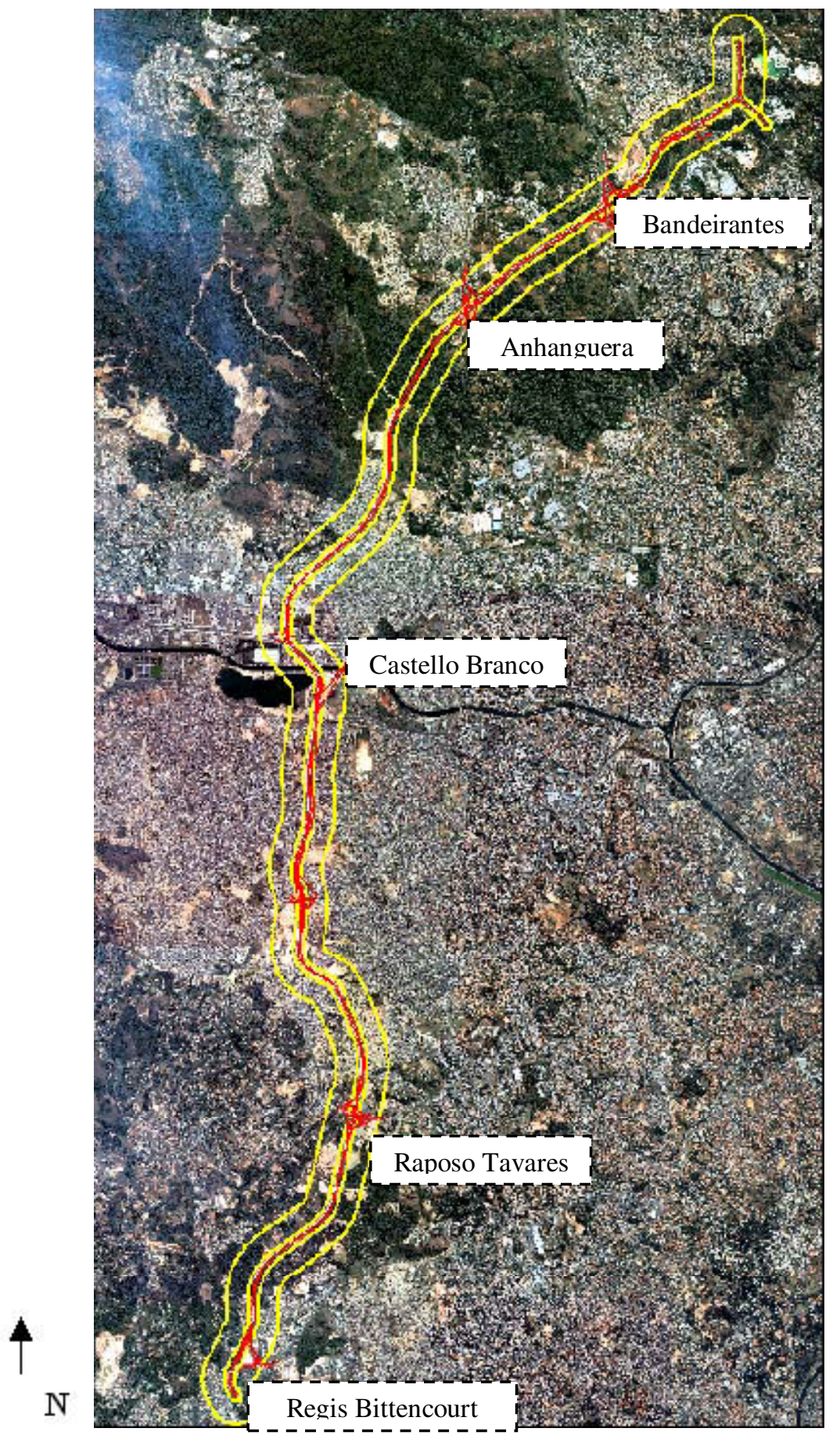

Figura 2: Mosaico Aerofotogramétrico (2002)

Fonte: São Paulo (2005)

São Paulo

2009 
A diferença na ocupação do trecho 1 do Rodoanel (do bairro de Perus ao início do túnel de acesso a Osasco) e do trecho 2 (do final do túnel de Osasco até o município de Embu) mostrou-se visível já no ano de 2005 no relatório elaborado pela FAUUSP (2005), onde é exposta a existência de 12 assentamentos precários no trecho 1, sendo que estes correspondem a aproximadamente $7,15 \mathrm{~km}$ do trecho oeste do Rodoanel; e no trecho 2 mostra a existência de 18 assentamentos precários, sendo que estes correspondem a aproximadamente $24,45 \mathrm{~km}$ do trecho oeste do Rodoanel. O mesmo não ocorre com o número de indústrias e comércios, pois no trecho 1 existia 7 estabelecimentos, enquanto no trecho 2 havia 47 estabelecimentos $^{8}$ (Tabela III e Gráfico III).

Tabela III: Quantidade de Assentamentos Precários e Indústrias/Empresas

\begin{tabular}{|c|c|c|}
\hline & Trecho 1 (7,15km) & Trecho 2 (24,45km) \\
\hline Assentamentos precários & 12 & 18 \\
\hline Indústrias/comércio & 7 & 47 \\
\hline \multicolumn{2}{|c|}{$\begin{array}{c}\text { Fonte: FAUUSP (2005) } \\
\text { Organização da autora }\end{array}$} \\
\hline
\end{tabular}

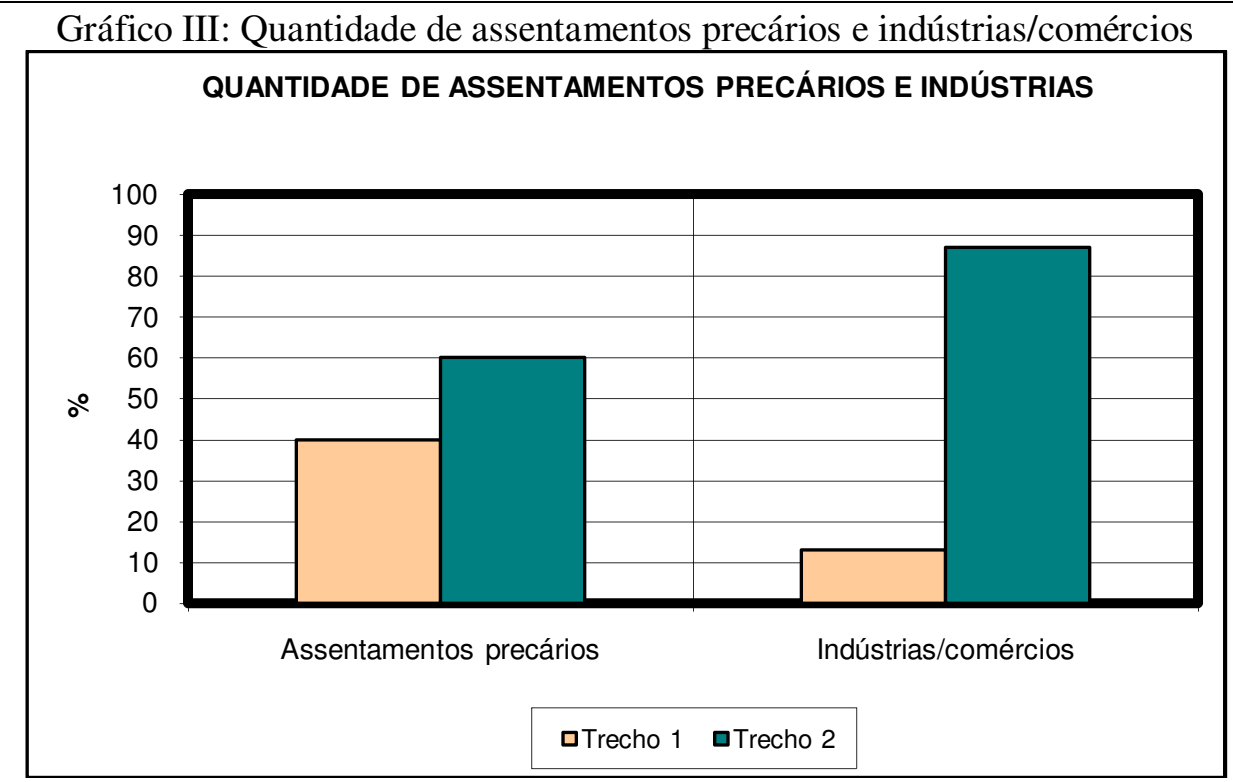

Fonte: FAUUSP (2005)

Organização da autora

\footnotetext{
${ }^{8}$ É válido ressaltar que, neste caso, o buffer da rodovia foi de $5 \mathrm{~km}$ e que a indústria Petrobrás é considerada uma Instituição. Para a elaboração da presente tabela, a empresa Petrobrás foi considerada Indústria.
} 
Atualmente, dos anúncios de venda ou aluguel de terrenos grandes ou galpões industriais pesquisados em jornais e anúncios on line e in loco no mês de abril de 2009, a maior parte localizava-se no trecho que compreende Barueri, Cotia, Embu, Carapicuíba, Itapecerica e Osasco.

Todos os anúncios possuem como vantagem o acesso ao Rodoanel ou áreas de entroncamento com outras rodovias radiais nestes municípios. Por meio desta análise, se reforça que a predominância industrial/empresarial está no trecho após o túnel de acesso a Osasco e não no trecho que abrange os bairros de Perus e Jaraguá no município de São Paulo.

\subsection{Estudos prévios para a implantação de eixos viários visando a diminuição de impactos sociais e ambientais}

De maneira geral, os impactos decorrentes da obra acontece, na maioria das vezes, no entorno da faixa de domínio e junto às áreas de apoio à construção (impactos pontuais decorrentes de obras de terraplenagem, instalação de canteiros de obras, manuseio de equipamentos, implantação de infra-estrutura para execução da obra e abrigo de funcionários alteram bruscamente o meio físico.

Com a operação do sistema viário, as alterações são ocasionadas pela necessidade de sua utilização. A área ocupada pelo eixo viário e seus acessos, o traçado das curvas e rampas, o local exato por onde o traçado vai passar, podem ser fatores essenciais para alterar seu entorno. Também existem as alterações ocorridas a médio ou longo prazo, são as que necessitam de tempo para se instalar e atribuir uma nova caracterização no espaço em decorrência do uso do novo empreendimento ou das conseqüências deste uso.

A implantação de um eixo viário depende de aspectos presentes na engenharia civil e no planejamento urbano, considerando seu desenho, as características topográficas, geológicas e geográficas do meio.

Segundo Lisboa (2002), que estuda a implantação das rodovias que atravessam áreas urbanizadas, afirma que somente a partir da década de 1970, principalmente em países desenvolvidos, o meio técnico começou a considerar que,

[...] a implantação de uma rodovia poderia proporcionar conseqüências negativas à qualidade de vida da população residente nas proximidades da mesma e ao próprio usuário, considerando aspectos como ruído, desmatamento, desapropriações, interferências nas diretrizes dos planos diretores do municípios atravessados, entre outros impactos. (p.2) 
A engenharia civil tem papel fundamental no impacto gerado ao meio ambiente e a sociedade, já que as cidades necessitam das construções, sendo ao mesmo tempo, impactadas por elas. Este paradoxo revela a importância de um planejamento que vai além do projeto de engenharia, visualizando o entorno, o ambiente natural e social em que a execução da obra e a construção final estarão inseridas exercendo suas funções. Toda obra, principalmente as consideradas de grande porte, exerce ações causadoras de modificações no ambiente em que se encontra no momento de seu planejamento, execução, finalização e também após sua conclusão, já que é construída com o objetivo de exercer determinada função.

"A possibilidade do engenheiro intervir no meio ambiente adquire as dimensões que a técnica lhe oferece, mas a extensão dos efeitos das intervenções foge-lhe à percepção." (LISBOA, 2002, p.11).

Diante da necessidade econômica e também social gerada pela locomoção de pessoas, a construção de eixos viários é indispensável, e junto, o estudo para seu melhor traçado que envolve uma delicada análise de aspectos econômicos, sociais e ambientais. Por isso são realizados anteriormente à construção diversos estudos e relatórios, como o EIA / RIMA (Estudos de Impacto Ambiental / Relatório de Impacto no Meio Ambiente) ${ }^{9}$ com o objetivo de minimizar impactos com a construção do eixo viário. Segundo Jorge, Pineda e Férnandez (2004), "El objetivo del EIA (estudio de impacto ambiental) de uma carretera es encontrar el corredor que minimiza el impacto y seleccionar le mejor línea alternativa entre dos lugares."

Segundo documento elaborado pela DERSA, a AAE (SÃO PAULO, 2004), os principais impactos sociais e ambientais de uma rodovia podem ser agregados em três categorias para fins de análise. São estas: 1. Impactos diretos e indiretos relacionados a implantação da obra; 2. Os impactos decorrentes da operação do empreendimento; 3. Efeitos de médio e longo prazo sobre a eficiência do sistema de transporte e ocupação do uso do solo.

O eixo viário é um elemento urbano que, junto a outros elementos como os meios de transporte, abre novas possibilidades de comunicação entre diferentes áreas. Estas áreas, por sua vez, valorizadas por esta acessibilidade, podem sofrer modificações.

\footnotetext{
${ }^{9}$ Lei Federal 6938/81. Resolução CONAMA 01/86.

${ }^{10} \mathrm{O}$ objetivo do EIA (Estudos de Impacto Ambiental) de uma estrada é encontrar o corredor que minimiza o impacto e selecionar a melhor linha alternativa entre os lugares. (Tradução livre da autora).
} 
O primeiro efeito que uma via regional ou terminal de transporte urbano provoca nos terrenos adjacentes é a melhoria de sua acessibilidade, e daí, sua valorização [...] sendo os transportes intra-urbanos os maiores determinantes das transformações dos pontos, as vias de transporte têm enorme influência não só no arranjo interno das cidades, mas também sobre os diferenciais de expansão urbana. (VILLAÇA, 2001, p.80).

$\mathrm{O}$ autor ainda afirma que

O simples registro de transformações espaciais não é suficiente para caracterizar a estruturação ou a reestruturação [do espaço urbano]. É preciso mostrar como mudanças em um elemento da estrutura provocam mudanças em outros elementos. (p.13).

As reestruturações trazidas pelas obras e implantação de eixos viários unidas a um crescimento desprovido de planejamento, como ocorre em muitas cidades brasileiras, resultam em impactos que refletem diretamente na qualidade de vida da população e podem gerar modificações negativas na paisagem, mesmo no caso de áreas já consideradas urbanas antes da construção do eixo viário. A autora Damiani (2004, p.41) cita o Rodoanel Mario Covas na RMSP como exemplo de "reorganização potencial do uso dos espaços, a partir da produção desta obra viária de interligação de todas as regiões da metrópole, num grande anel." Segundo Villaça (2001, p.153), no caso das rodovias radiais, as transformações ocorrem principalmente devidos as indústrias que tendem a se deslocar em sentido radial. Para exemplificar, o autor cita a metrópole de São Paulo, onde as indústrias começaram no Brás e na Mooca, depois em direção a Santos, foram para Vila Prudente e Ipiranga, São Caetano, Santo André e Mauá. O autor afirma que "No caso das indústrias, este caminho ainda é compreensível, pois elas seguiam a ferrovia e hoje seguem rodovias” (p.153).

Além das áreas industriais, as grandes áreas comerciais se desenvolvem seguindo longas radiais [...] estas formações, aliás, mostram de maneira eloqüente, o papel decisivo que a acessibilidade ao centro e o transporte do ser humano desempenham na estruturação intra-urbana (VILLAÇA, 2001,p.155).

No caso de residências existem outros fatores que pesam na decisão de ocupação como disponibilidade de empregos e fácil acesso a serviços urbanos. O mais comum dos exemplos de modificação social do espaço urbano, no que refere às áreas residenciais, são os casos de desapropriação que consiste no ato de retirar um morador de sua propriedade, com base legal, ressarcindo, de alguma forma, seus prejuízos. Segundo Lisboa (2002, p.39), é comum a necessidade de efetuar desapropriações para implantar projetos rodoviários, sejam 
de propriedade públicas ou mesmo propriedades privadas. Mesmo que uma área esteja apropriada irregularmente, a população deve ser reassentada de acordo com princípios e diretrizes de Agências de Desenvolvimento Internacionais e os Direitos Humanos. Para a construção do Rodoanel Mario Covas, por exemplo,

[...] foram atendidas 2.494 famílias, provenientes de 27 núcleos. Dessas, 56\% optaram pelo recebimento de indenização e $44 \%$ pelo reassentamento, cujo processo se deu ao longo de 2 anos, desde o cadastramento até a mudança para o novo conjunto. Outras 501 famílias foram indiretamente atingidas e, para esse grupo foram executados serviços de reparos e melhorias das habitações. Muitas vezes as indenizações pagas, conforme teoria do Ministério Público, não foram suficientes para a compra de nova moradia em área regular. (FAUUSP, 2005, p. 113)

Embora a desapropriação seja muito comum em terrenos e nas proximidades por onde são construídas novas rodovias, é um assunto que causa muita discussão. Muitas famílias negam-se a serem removidas porque dizem que o dinheiro da indenização não é suficiente, pela precariedade das novas moradias ou pela distância de seu trabalho ou de algum meio de transporte.

Outra modificação comum durante as obras, e após a implantação de eixos viários, é o impacto ambiental como o desmatamento, ocupação de nascentes e remoção de camada vegetal. As modificações ambientais e sociais se fundem, não há como vê-las separadamente, uma vez que alterado o meio físico, os resultados refletem no meio social.

A definição dos valores a partir das modificações ocasionadas pela acessibilidade também são fatores que agem sobre o espaço reestruturado e definem, por sua vez, novas formas tornando o ciclo contínuo. A autora Damiani (2004, p.41) afirma que "o espaço aparece como puro bem financeiro, imerso no movimento do capital como uma corrente de valor, que envolve toda ordem de especulações com a terra."

Quando fluxos migratórios e mecanismos de ação do mercado imobiliário não contam com um planejamento adequado tornam-se fatores que podem trazer alterações negativas. Assim, a atuação do poder público é imprescindível para se obter o controle e planejamento adequado da expansão da mancha urbana. Segundo a DERSA (SÃO PAULO, 2005b, p.4),

Em termos práticos, essa atuação deve ser de molde a redirecionar o assentamento de novos fluxos migratórios externos na mancha urbana, bem como controlar novas migrações intrametropolitanas e ainda para relocar, na 
medida do possível, os contingentes que hoje ocupam áreas ambientalmente sensíveis.

Não há como não considerar as ações do mercado imobiliário diante da valorização de terras do entorno dos eixos viários gerada pela acessibilidade. Segundo Villaça (2001, p. 355)

Quando o setor imobiliário, representando os interesses das burguesias, escolhe uma determinada localização para um empreendimento, ele pesa os vários prós e contras envolvidos nessa escolha. Dentre os primeiros, destaca-se o meio ambiente e dentre os segundos, os deslocamentos envolvidos. A infra-estrutura vem depois; ela é trazida pelas burguesias, inclusive a de transportes, que é continuamente aprimorada, uma vez que envolve os deslocamentos.

Damiani (2004) faz observações com relação ao eixo viário Rodoanel

[...] apenas acessando a internet, em sites relativos ao Rodoanel, sabe-se dos novos negócios sugeridos por este grande anel, inclusive um fundo imobiliário foi lançado na Bolsa de Valores de São Paulo, pela primeira vez, envolvendo investimentos externos e tendo como lastros das futuras ações e papéis o patrimônio referente à aquisição, entre outros negócios, de 6 imóveis, sendo que um deles instalado no quilômetro 17, da rodovia Anhanguera, próximo ao Rodoanel Mario Covas, entre os trechos norte e oeste do mesmo [...] O processo de valorização potencial das áreas adquiridas dá garantia de elevação da rentabilidade dos cotistas (p.41).

O repórter Tognolli (2006) cita, em reportagem no site da Revista Consultor Jurídico, que "o Secretário Adjunto de Transportes do estado de São Paulo, Paulo Tromboni, afirmou durante um debate no Instituto de Arquitetos do Brasil - IAB, que o principal efeito do Rodoanel é valorizar a terra ao longo do traçado e reservá-la para uso mais nobres, com maior uso de capital (citado a fls.30 do DOC 35)." (TOGNOLLI, 2006, p.8) ${ }^{11}$. O repórter Tognolli (2006, p.9) ressalta que "se um dos principais argumentos para justificar a obra tem sido a logística e a instalação de empresas de logística próximas ao Rodoanel, a existência de "bolhas"12 é algo seguro e a conclusão de que não haverá indução à ocupação cai por terra." Já a autora Damiani (2004, p.42) diz que pode ser induzido um processo inverso: "ele as expulsará em prol de investimentos regularizados e valorizados, levando a periferia para áreas

\footnotetext{
${ }^{11}$ Reportagem disponível em: http://www.conjur.com.br/2006-mar-01/mp-sp_entra_acao_ambiental_obra_rodoanel?pagina=8

12 Hipótese que uma grande empresa localiza-se nas proximidades do Rodoanel e atrai moradores ou novas empresas. Nesse caso tem-se uma "bolha". Frase baseada da reportagem de Tagnolli (2006). Disponível em: http://www.conjur.com.br/2006-mar-01/mp-sp_entra_acao_ambiental_obra_rodoanel?pagina=7
} 
ainda mais distantes. Todas as formas provisórias de apropriação da terra nas áreas periféricas tenderão a serem redefinidas."

\subsection{Caracterização do entorno do trecho estudado do Rodoanel Mario Covas}

A decisão política de implantação do Rodoanel foi tomada em 1997 pela União, pelo estado de São Paulo e Prefeitura da cidade de São Paulo. O projeto do traçado completo do Rodoanel visa distar de 20 a 40 km da capital, e segundo a DERSA (SÃO PAULO, 2004, p.1) "é uma rodovia "classe 0", isto é, possui alto padrão técnico e controle total de acessos, sendo bloqueada ao acesso de áreas lindeiras". Segundo relatório sobre a implantação do trecho oeste do Rodoanel elaborado pela FAUUSP (2005, p.53), com relação a análise do RIMA (1998) no que se refere a rodovia "classe 0":

[...] a ocupação formal decorrente da atratividade gerada pela presença do anel viário, seja habitacional, do setor terciário ou industrial, seria supostamente refreada pela grande restrição à criação de acessos diretos à rodovia, o que eliminaria a "vantagem" de acessibilidade da mesma. Entretanto, embora destaque que tal fenômeno ocorrerá apenas nos acessos oficiais inicialmente previstos, a própria DERSA admite que nessas regiões próximas aos trevos de cruzamento com as rodovias e avenidas que têm ligação oficial ao Rodoanel deve ocorrer um aumento do número de empresas.

O acesso ás áreas lindeiras está regulamentada pelo Decreto Estadual n. 47.889/03 ${ }^{13}$.

O Decreto Estadual, em seu artigo $1^{\circ}, \S 2^{\circ}$, estabelece que

Nos Trechos Oeste e Leste/Nordeste, progressivamente à conclusão dos diversos segmentos, serão admissíveis acessos exclusivamente a propriedades lindeiras que empreendam atividades relacionadas ao segmento de carga, estruturadas de forma a propiciar a integração inter e intramodal.

O Decreto também determina que

Os acessos de que cuida o parágrafo anterior somente serão exeqüíveis desde que tecnicamente viáveis, através de vias marginais a serem construídas às expensas dos interessados, sobre as faixas dominiais e em suas extremidades laterais, passando a integrar a rodovia e sem que decorra aos autorizatários quaisquer direitos, regalias ou indenizações.

A negociação em torno das condições de implantação do Rodoanel se deu exclusivamente entre a DERSA e cada município isoladamente. Dessa forma,

${ }^{13}$ Disponível em: http://homologa.ambiente.sp.gov.br/rodoanel/pba/M3_07_02.pdf. Acesso em 22 jun 2008. 
cada Prefeitura, com diferentes capacidades administrativas, teve que arcar (ou não) com os custos de revisão da legislação e de aumento da demanda por atividades de controle e fiscalização do uso do solo. (FAUUSP, 2005, p.91)

No que diz respeito a ocupação no entorno do Rodoanel Mario Covas, o governo do estado foi responsável pela "Agenda Metropolitana", um projeto desenvolvido no âmbito da EMPLASA, reunindo representantes dos municípios da RMSP, que estabelece diretrizes para ação do território que visam:

- Recuperação e diversificação de funções urbanas em áreas centrais.

- Qualificação em anéis urbanizados intermediários.

- Correção de efeitos da ocupação indevida.

- Promoção de usos sustentáveis para conservação de recursos naturais.

Além da Agenda Metropolitana, este trabalho culminou no envio de projeto de lei complementar à Assembléia Legislativa (PLC 6/2005, de maio de 2005), que reinstitucionaliza a RMSP e estabelece como escopo de interesse de seu Conselho de Desenvolvimento, os campos funcionais de planejamento e uso do solo, transporte e sistema viário regional, habitação, saneamento básico, meio ambiente, desenvolvimento econômico e atendimento social. No que diz respeito ao transporte coletivo, está em elaboração um plano de transporte que visa a criação de uma cenário urbano equilibrado, com contenção da mancha urbana, com políticas que visam aproximar empregos e residências, considerando inclusive o estabelecimento de subsídios habitacionais para a população de baixa renda a serem financiados com a redução da extensão das viagens.

Foi também elaborado pela DERSA e Secretaria de Transportes do estado de São Paulo em julho de 2004, o relatório de Avaliação Ambiental Estratégica - AAE (SÃO PAULO, 2004) que teve como objetivo avaliar a viabilidade ambiental do Rodoanel, buscando obter a compreensão da dinâmica da região atravessada pelo eixo viário; a avaliação da contribuição ambiental do programa e suas articulações com as demais políticas públicas; as diretrizes para definição de traçados nos novos trechos do Rodoanel; as diretrizes para gestão do Programa Rodoanel.

Enquanto ao EIA de uma rodovia caberia escolher a alternativa locacional e tecnológica, detalhar os impactos locais e definir as medidas mitigadoras e de compensação com a finalidade de alcançar a Licença Prévia e prosseguir na 
implantação, à AAE caberia uma análise abrangente dos efeitos de longo prazo sobre a geografia física e humana atravessada permitindo direcionar o esforço de projeto e de avaliação ambiental detalhado dos EIAs, assim como resolver as interfaces de um programa com os vários setoriais e esferas institucionais que com ele interagem na modificação da região atravessada (SÃO PAULO, 2004, p.40).

O trecho oeste do Rodoanel foi concluído em 1998, sendo o primeiro e o único construído até o presente momento (o trecho sul está em construção). Localiza-se no anel peri-urbano da RMSP, território com características heterogêneas e dotado de dinâmica própria, desenvolvendo-se em grande parte na bacia do rio Tietê, formando um território físico sem acidentes geográficos relevantes (SÃO PAULO, 2004). De acordo com a empresa DERSA (SÃO PAULO, 2005, p.7)

A geografia sócio-econômica caracteriza-se por atravessar uma região bastante conurbada, particularmente nos municípios de Carapicuíba e Osasco, com assentamentos consolidados e em expansão de baixo padrão urbano, áreas urbanas densamente ocupadas, graves carências de infra-estrutura e baixa qualidade ambiental e urbana.

O trecho oeste interliga as rodovias Bandeirantes, Anhanguera, Castelo Branco, Raposo Tavares e Regis Bittencourt, possui 31,6 quilômetros de extensão e faixa de interesse de 130 metros. Foi implantado conexão de avenidas municipais nas divisas dos municípios de Osasco e Carapicuíba (Trevo da Padroeira) e a Estrada Velha de Campinas (SP-332) por meio da Avenida Raimundo Pereira de Magalhães, na zona Noroeste do município de São Paulo.

A rodovia Rodoanel Mario Covas será inteiramente inserida na área metropolitana de São Paulo e responsável por interconectar as rodovias radiais que ligam a RMSP com outras metrópoles do interior do estado e do país. Foi projetado com o principal objetivo de aliviar o tráfego no sistema viário metropolitano, separando o fluxo da RMSP do fluxo interno, servindo de alternativa para motoristas que não necessitam passar pelo centro urbano ou marginais.

As simulações para caracterização dos beneficiários da implantação do Rodoanel no horizonte de 2020 revelaram que $72 \%$ dos benefícios incrementais da implantação de todos os trechos corresponde à categoria de viagens internas à RMSP. Assim, além da importante função de interconexão entre grandes rodovias radiais que afluem à metrópole, o Rodoanel confirma sua dimensão de elemento estruturador do tráfego interno da RMSP (SÃO PAULO, 2004, p.17). 
Segundo a AAE (SÃO PAULO, 2004), o Plano Diretor de Desenvolvimento de Transportes - PDDT é um instrumento de planejamento desenvolvido pela Secretaria Estadual de Transportes para o período de 2000 a 2020 e não considera o Rodoanel um plano de transporte isolado e sim um imprescindível empreendimento rodoviário de cargas, parte integrante de uma política de transportes estadual.

A movimentação de cargas no estado é mais concentrada na região macro-metrópole constituída pela RMSP e pelo espaço geoeconômico que a envolve, delimitado pelo quadrilátero Campinas, São José dos Campos, Sorocaba e Santos. Apesar disso, os fluxos de comércio inter-regional e internacional não são desprezíveis: 76\% saída e origem no estado; $12 \%$ comércio inter-regional, São Paulo e demais estados; $6 \%$ são de passagem pelo estado e $6 \%$ comércio exterior. A concentração e movimentação de cargas envolvendo a RMSP diretamente, de interesses de estudo do Rodoanel significa 50\% da carga transportada no estado segundo o PDDT (SÃO PAULO, 2000). Para atender a demanda de cargas é necessário a instalação de Centros Logísticos Integrados - CLI. Como arcabouço físico operacional também faz parte melhorias no Porto de Santos e São Sebastião, melhorias de acessos rodo-ferroviários de cargas aos terminais portuários; serviço ferroviário de cargas entre a RMSP e o interior de outros estados; implantação integral de anéis rodoviários e ferroviários (Rodoanel e Ferroanel). A implantação dos dois eixos viários transformaria a logística urbana de radial para anelar, o que aliviaria trechos de intenso movimento que levam aos movimentados centros comerciais e de serviços. Este é o objetivo da implantação do Rodoanel Mario Covas segundo documentos analisados da Secretaria Estadual de Transportes (SÃO PAULO, 2000).

Segundo a empresa DERSA

[...] a nova plataforma logística permitirá deslocar as transações para o entorno da RMSP e alcançar o destino final na metrópole com veículos mais adequados ao viário urbano. Como benefício adicional, imensas áreas hoje dedicadas às atividades logísticas na cidade de São Paulo poderão paulatinamente encontrar usos mais nobres e consentâneos com sua localização em regiões altamente urbanizadas de uma metrópole global (SÃO PAULO, 2004, p.20)

A área de estudo abrange a cidade de São Paulo, especificamente os bairros de Perus, onde se inicia trecho oeste do Rodoanel e o bairro Jaraguá. A área de estudo abrange também a vila Santa Fé no município de Osasco. Será estudado o entorno do trecho que segue até o túnel de acesso a Osasco (Figuras 3 e 4). 


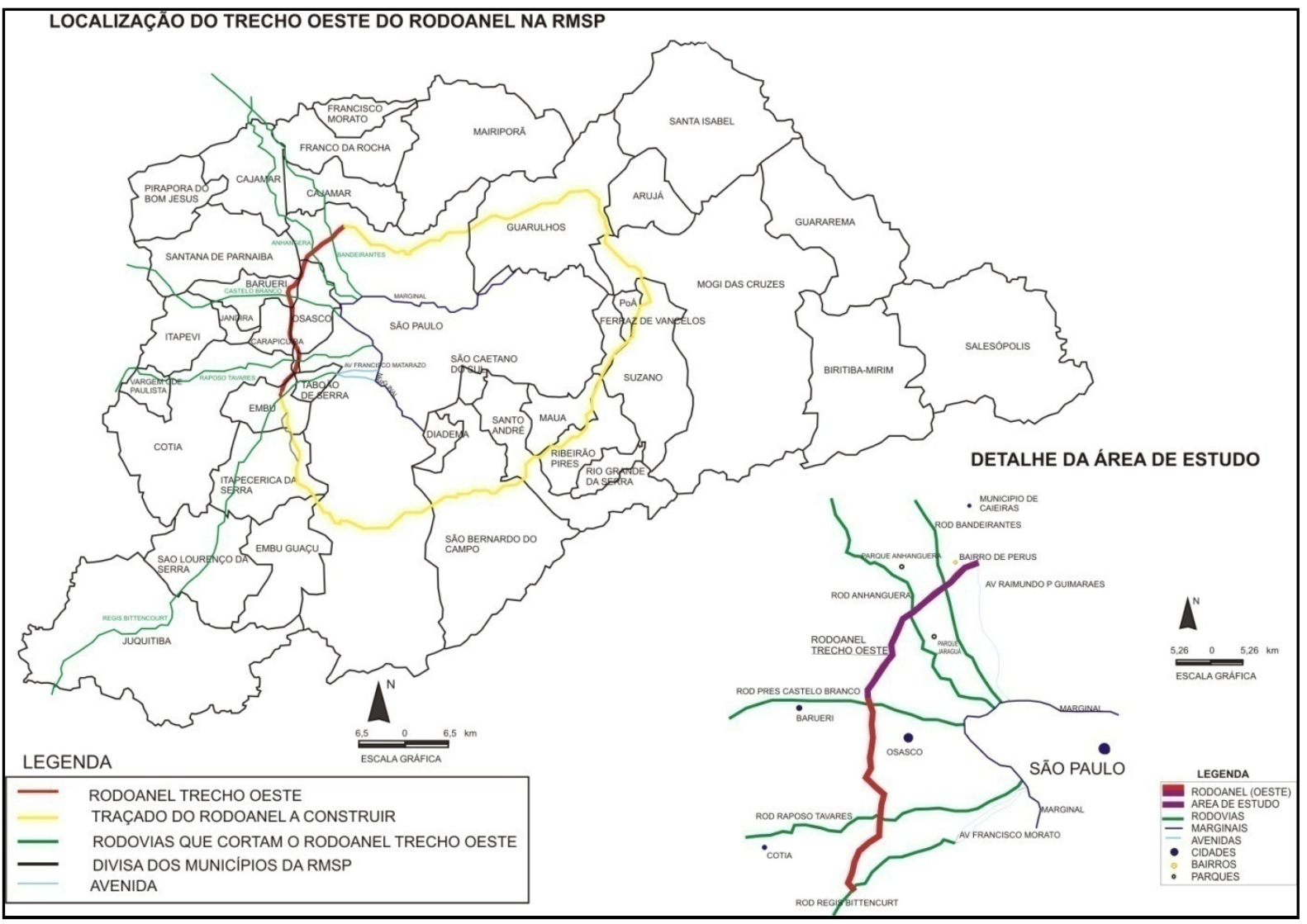

Figura 3 e 4: Localização do Rodoanel na RMSP

Fontes: Fig 2: Fundação Escola de Sociologia e Política de São Paulo. (SÃO PAULO, 2004). Fig 3:

Departamento de Estradas e Rodagem, 2004. Editado pela autora (2007)

O bairro de Perus é servido pelas rodovias Anhanguera, Bandeirantes e antiga Estrada Velha de Campinas, além do próprio Rodoanel. O bairro tem cerca de 70.600 habitantes e área de aproximadamente $57 \mathrm{Km}^{2}$, sofre com problemas de ocupações irregulares em diversos pontos, falta de infra-estrutura e conseqüente degradação ambiental.

Segundo Siqueira (2001, p.165), que entrevistou o Historiador de Perus ${ }^{14}$ e Presidente da Comissão Pró-emancipação, Sr. DemétrioVidal Lopes (1918-1998), a data correta do aniversário de bairro de Perus é 21 de setembro, pois é a data da criação do Distrito de Paz de Perus em 1934. Os principais problemas observados no bairro são escorregamentos de aterros constituídos por solos siltosos e micáceos por dificuldade de compactação; processos erosivos acelerados; desplacamento de rochas (maciços quartzíticos e filitos) (MEIO FÍSICO, 2000). A

\footnotetext{
${ }^{14}$ Considerado assim pelos moradores mais antigos do bairro, segundo entrevista com moradores e com seu filho Moisés Vidal no ano de 2009.
} 
dinâmica do bairro se intensificou no início do século $\mathrm{XX}$, principalmente devido a proximidade de jazidas de calcário, da ferrovia, e a instalação da Fábrica de Cimento Portland Perus na década de 1920, o que ocasionou a formação de vilas de trabalhadores existentes até hoje. Segundo Siqueira (2001, p.42)

Em 1933-39, diversas usinas vieram juntar-se à Perus. Por volta de 1940, quase todo o cimento consumido no Brasil era de procedência nacional, situação que perduraria durante a Guerra graças à interrupção de importações. A demanda, porém, continuava crescendo devido a programas de obras do governo e a um boom de construções imobiliárias gerado por facilidades governamentais para financiamentos, caracterizando um quadro de demanda reprimida que, acabada a guerra, seria seguido por um prolongado período de prosperidade.

Segundo o autor, nos anos de 1973 e 1974, a fábrica, a ferrovia e as atividades de mineração sofreram confisco federal devido a dívidas e impostos não pagos. Em 1979, o Sítio Santa Fé, nas proximidades, foi também confiscado pela União e negociado com a Prefeitura de São Paulo que o transformou no Parque Anhanguera.

O surgimento do bairro Perus aconteceu no entorno da ferrovia e da fábrica de cimento, ainda com características rurais. No início dos anos de 1980 houve o declínio das atividades da fábrica até seu encerramento no final da década devido a problemas administrativos e ambientais.

A área de estudo abrange também o bairro Jaraguá, conhecido pelas cavas de mineração de ouro pioneiras mais próximas da capital paulista, encontrada ainda no final do século XVI. De acordo com histórico do Pico do Jaraguá (PARQUE DO JARAGUÁ, 2008) ${ }^{15}$, "O então Governador, Dr. Francisco de Souza, satisfazendo a estabilidade econômica do Rei e dos cortesões da metrópole, explora ao máximo o ouro da região, que por volta de 1670 , começa a escassear." Segundo Carneiro (2002), "o esgotamento gradual e as expressivas descobertas em Minas Gerais deslocaram o foco de interesse dos portugueses”. Carneiro (2002, p.512) salienta "mesmo que as pesquisas estejam interrompidas, os requerimentos de pesquisa mineral registrados junto ao DNPM indicam que a área ainda interessa à mineração." As cavas localizam-se na vila Morro Doce, ás margens da rodovia Anhanguera, hoje encobertas pelo mato, solo e casas. Segundo Carneiro (2002), as cavas "dispõem-se entre

\footnotetext{
${ }^{15}$ Texto disponível em "Histórico" no site "Pico do Jaraguá" recomendado para pesquisa durante trabalho de campo no Parque do Pico do Jaraguá. Disponível em: http://www.picodojaragua.com.br/historico.html. Acesso em 09 jun 2008.
} 
rochas metassedimentares e metavulcânicas do Grupo São Roque. Esta unidade do Proterozóico Superior esconde-se, a oeste, sob sedimentos da Bacia do Paraná, na região de Sorocaba".

Ocupações urbanas dominam atualmente a região das cavas de ouro. A transformação da paisagem foi rápida: em quatro décadas a urbanização vem substituindo em ritmo acelerado sítios e chácaras da zona rural. Cada uma das cavas possui paredes muito inclinadas a subverticais, desprovidas de vegetação e cobertas de material escorregado das encostas. A faixa em que se distribuem as escavações estende-se segundo a direção WNW por aproximadamente $6 \mathrm{~km}$, com menos de $800 \mathrm{~m}$ de largura. Nas áreas não ocupadas a vegetação remanescente é principalmente de eucaliptos e alguns restos descaracterizados de mata nativa.(CARNEIRO, 2002, p. 512) [...] Deve-se advertir que, em breve, tais testemunhos do passado serão sufocados pela expansão urbana. De um lado da Via Anhangüera, eles convivem com os cemitérios; do outro, com a cidade e seus detritos, que logo riscarão do mapa o caminho tortuoso, se nada for feito para conter a "urbanização" mal-planejada. (p. 515)

No início do século XIX, começaram na região, as práticas agrícolas, e no final deste século, a fazenda do Jaraguá foi vendida. Segundo o histórico do Pico do Jaraguá (PARQUE DO JARAGUÁ, 2008), em 1940

A fazenda do Jaraguá passa ao domínio do Patrimônio Público [...] Devido a vegetação precária, o decreto determinava a plantação de jequitibás, jacarandás, ipês, sapucaias, paineiras, canelas, aroeiras, perobas, coqueiros, pau-brasil, guarupus (ficheiros), etc. (quase mil árvores) [...] Foi constituída uma comissão de várias pessoas ligadas à fauna, com a idéia de fazer do local uma grande área de lazer (não funcionou sugestões, não foram concretizadas). A partir disso, a Fazenda ficou exposta a várias investidas como as construções da torre de transmissão da Rádio Bandeirantes e dos postos das polícias militar e civil, alterando a paisagem original.

Em 1961, através do decreto 38391, de 03 de maio, foi criado o Parque Estadual do Jaraguá sob responsabilidade da Secretaria da Agricultura, dez alqueires foram cedidos à Secretaria de Turismo para implantar o complexo turístico na região. Nesse mesmo ano, o governador Ademar Pereira de Barros autorizou a concessão de parte da área para a construção de linhas de transmissão para as redes Bandeirantes, Globo e Cultura de televisão.

Em 1975, paisagistas, historiadores e engenheiros buscaram uma infra-estrutura, adequada e procurando não ferir a paisagem da região. No topo, foi feito uma marquise de $1730 \mathrm{~m}$. com sanitários, lanchonetes, posto de informação, três belvederes (mirantes) e uma grande peça movimentada para ter uma visão panorâmica da cidade. No sopé do morro, existem espaços livres para atividades 
de recreação e permanecia onde há anfiteatro, lanchonetes e conjuntos sanitários. Em 1978, foi pedido o tombamento do Parque Estadual do Jaraguá.

Também é parte da área de estudo a vila Santa Fé, pertencente ao município de Osasco, caracterizada por fragmentos de mata e ocupações residenciais e industriais, principalmente nas proximidades da rodovia Anhanguera.

Osasco é uma cidade emancipada desde 1962 e tornou-se município pertencente à RMSP, segundo o Museu Municipal de Osasco Dimitri Sensaud De Lavaud (OSASCO, 2007). O município de Osasco é servido pela rodovia Castelo Branco, Anhanguera e Raposo Tavares que cruzam com o Rodoanel. O trecho oeste do Rodoanel abrange sete municípios, sendo estes, São Paulo, Embu, Cotia, Barueri, Carapicuíba, Osasco, Santana do Parnaíba16. A área de estudo abrange somente os bairros Perus e Jaraguá, no município de São Paulo, e o bairro Santa Fé no município de Osasco.

\footnotetext{
${ }^{16}$ Dados disponível no Parecer Técnico do Ministério da Fazenda. Disponível em: http://www1.seae.fazenda.gov.br/littera/pdf/08012006786200815.pdf
} 


\section{CAPITULO 3. PROCEDIMENTOS METODÓLOGICOS}

\subsection{Delimitação e escala da área de estudo}

Normalmente, a área de estudo para desenvolvimento de uma pesquisa é definida por seus limites naturais, como o caso de bacias hidrográficas que possuem uma delimitação natural, constituindo um espaço marcante para caracterização que levam aos caminhos mais adequados para um planejamento. No caso das áreas urbanas, não são definidas naturalmente, pois podem ultrapassar os limites de bacias e sub-bacias, como o caso da área metropolitana de São Paulo.

Uma área de estudo modificada ou fortemente modificada pelo homem contém em seu espaço, arranjos de elementos e informações que podem ser capazes de fornecer uma caracterização.

De acordo com Santos (2004, p.43), a área de estudo pode ser definida segundo limite territorial, raios de ação, corredores e unidades homogêneas. Se o planejamento visa à conservação de um território onde são comuns padrões de paisagem e atividades em extensão linear, como estradas [...] então pode-se utilizar como estratégia corredores que abrange uma faixa marginal às atividades e aos padrões de paisagem que se pretende avaliar. É válido ressaltar a importância das informações sobre os elementos presentes na área estudada serem analisados de forma integrada, mesmo que em diferentes escalas, visando resultados adequados ao planejamento urbano e ambiental que requer a união e relação de diversos elementos.

O Rodoanel, trecho oeste, é um corredor com atividades de extensão linear que localiza-se no anel peri-urbano da RMSP. De início, a área estudada abrangia aproximadamente 400 metros no entorno deste eixo viário. Segundo os autores Jorge, Pineda e Férnandez (2004) que estudam o planejamento de estradas e impactos ambientais, "considerando experiências prévias, se sugere um corredor de uns 400 metros de largura ao redor da linha entre a origem e o destino"17 (tradução da autora).

Durante os trabalhos de campo e análise das imagens aéreas, foram observadas que modificações pontuais da paisagem ocorrem em linhas perpendiculares ao eixo viário Rodoanel a mais de 400 metros. Dessa forma, optou-se por aumentar a área de estudo para

\footnotetext{
${ }^{17}$ Considerando experiências prévias se sugiere um corredor de unos $400 \mathrm{~m}$ de anchura alrededor de la línea entre el origem y el destino
} 
aproximadamente $2 \mathrm{~km}$, distância esta, também maior que a utilizada no relatório da empresa DERSA "Rodoanel Mario Covas: análise da evolução das alterações do uso do solo nas imediações do trecho oeste" (SÃO PAULO, 2005).

As escalas são definidas de acordo com os assuntos a serem representados nos mapas, podendo mudar conforme a necessidade de se observar um espaço com maior ou menor nível de detalhamento. Segundo o IBGE (BRASIL, 2004), "a escala representa a relação entre a medida de uma porção territorial representada no papel e sua medida real na superfície terrestre."

A escolha da escala das imagens aéreas faz parte da etapa preliminar da análise. Segundo Lombardo (1995, p.96), "a escala de uma fotografia é a razão entre uma distância fotografia e a correspondente distância do terreno."

Uma escolha adequada da área de estudo e da utilização da escala reflete diretamente nos resultado da pesquisa. Para Queiroz Filho (2005, p.55)

Conforme o caso, o distanciamento pode ser uma estratégia mais apropriada para a compreensão do objeto estudado. Ao ampliar parte de uma fotografia aérea, observa-se melhor os detalhes, mas perde-se a noção do conjunto e de seu relacionamento com as outras entidades. É fundamental selecionar a distância, isto é, a(s) escala (s) adequada(s) para entender um fenômeno.

Para a escolha da escala foi utilizada a tabela de classificação do uso da terra desenvolvido pela Universidade de Michigan (JENSEN, 1983) apud Novo (1995) (Tabela IV).

Tabela IV - Características do sistema de classificação de uso da terra por sensoriamento remoto

\begin{tabular}{|l|l|l|l|l|}
\hline \multicolumn{1}{|c|}{ CRITERIOS } & \multicolumn{1}{|c|}{ NIVEL I } & \multicolumn{1}{|c|}{ NIVEL II } & \multicolumn{1}{|c|}{ NIVEL III } & \multicolumn{1}{|c|}{ NIVEL IV } \\
\hline Utilização principal & Nacional & Nacional & $\begin{array}{l}\text { Estadual } \\
\text { Regional }\end{array}$ & Local \\
\hline Escala de mapeamento & $\begin{array}{l}1: 250.000 \\
1: 1000.000\end{array}$ & $\begin{array}{l}1: 125.000 \\
1: 250.000\end{array}$ & $\begin{array}{l}1: 50.000 \\
1: 125.000\end{array}$ & $\begin{array}{l}\mathbf{1 : 2 5 . 0 0 0} \\
\mathbf{1 : 5 0 . 0 0 0}\end{array}$ \\
\hline Mínima unidade mapeável & $\begin{array}{l}95 \mathrm{ha}- \\
1480 \mathrm{ha}\end{array}$ & $24 \mathrm{ha}-94 \mathrm{ha}$ & $4 \mathrm{ha}-94 \mathrm{ha}$ & $\mathbf{0 , 8 h a}-\mathbf{4 h a}$ \\
\hline Base para classificação & $\begin{array}{l}\text { Cobertura do } \\
\text { solo }\end{array}$ & $\begin{array}{l}\text { Cobertura do } \\
\text { solo }\end{array}$ & $\begin{array}{l}\text { Cobertura } \\
\text { Atividade }\end{array}$ & $\begin{array}{l}\text { Cobertura / } \\
\text { Atividade }\end{array}$ \\
\hline Fonte de dados & $\begin{array}{l}\text { Interpretação } \\
\text { de imagem }\end{array}$ & $\begin{array}{l}\text { Interpretação } \\
\text { de imagem }\end{array}$ & $\begin{array}{l}\text { Interpretação de } \\
\text { imagem e dados } \\
\text { de campo }\end{array}$ & $\begin{array}{l}\text { Interpretação } \\
\text { de imagens e } \\
\text { dados de } \\
\text { campo }\end{array}$ \\
\hline
\end{tabular}

Fonte: Jensen (1983) apud Novo (1988) 
Segundo Luchiari, Kawakubo e Morato (2005,p.46), “o tamanho de um objeto representado numa imagem deve ser considerado em função de suas escala. Um objeto pode ser distinguido pelo seu tamanho em relação a outros que sejam representados na imagem."

Segundo Soeters e Van Westen apud Chao (1998), os mapas de escala média podem ser utilizados para determinação de zonas de ameaças em áreas afetadas por grandes estruturas de engenharia, rodovias e urbanização.

- Escala Nacional $<1: 1.000 .000$

- Regional $<1: 100.000$ a 1:50.000

- Média < 1:25.000 a 1: 50.000

- Grande $<1: 5.000$ a 1:15.000

Dessa forma, as fotografias aéreas são trabalhadas dentro da escala média, possibilitando o estudo em áreas urbanas.

A área estudada abrange os bairros de Perus e Jaraguá no município de São Paulo totalizando uma área de $39,75 \mathrm{~km}^{2}$. Em Osasco, a área de estudo abrange uma vila denominada Jardim Santa Fé, uma parte do "Morro de Jesus" e um trecho da rodovia Anhanguera totalizando uma área de $2,03 \mathrm{~km}^{2}$ (Figura 5). 


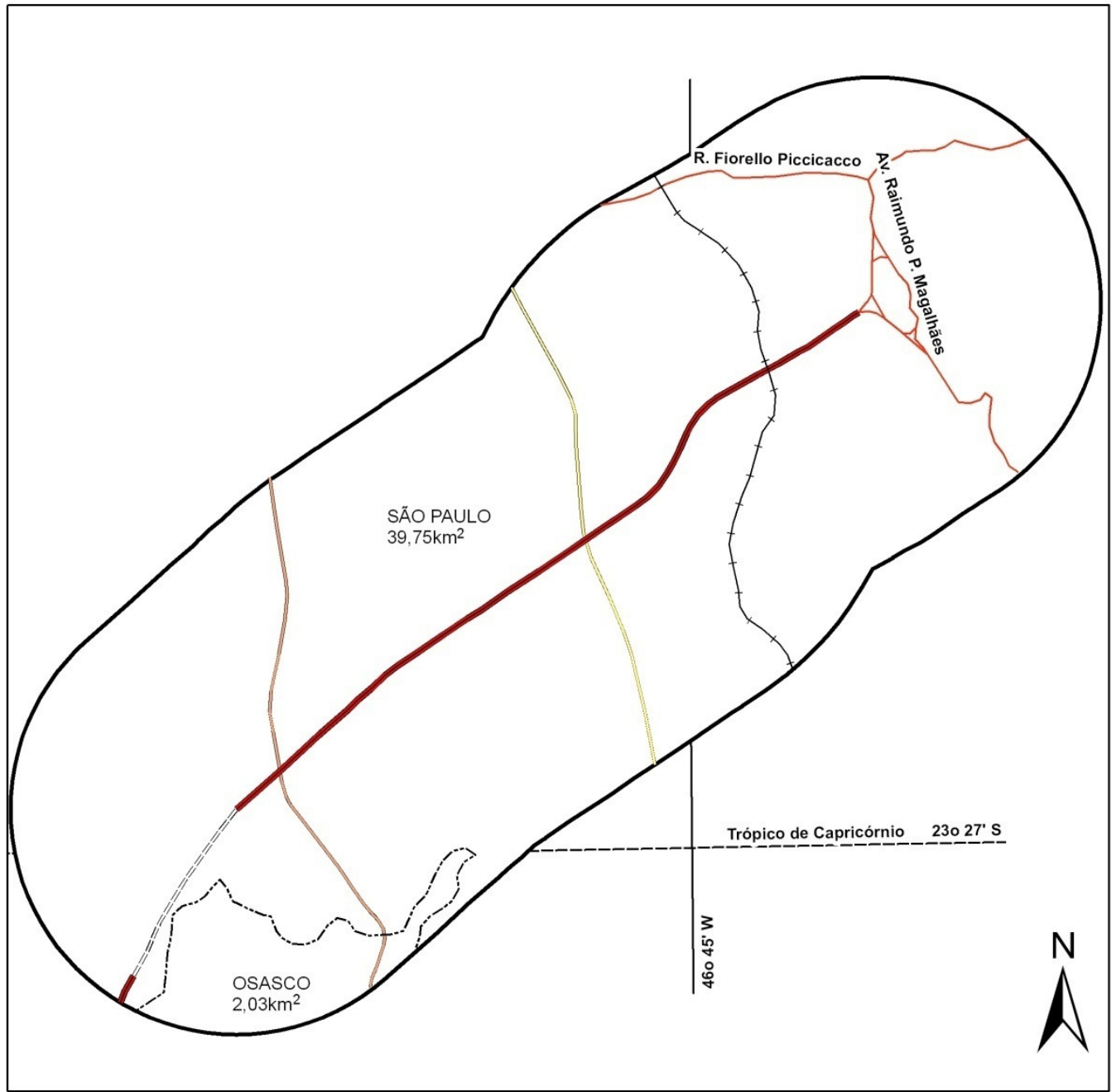

\section{Legenda}

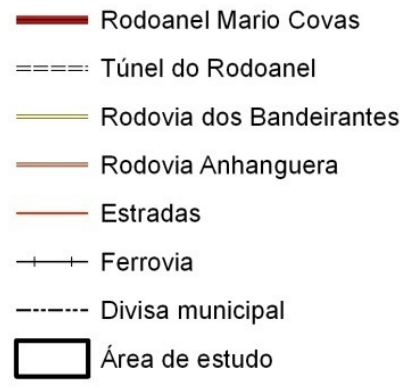

Figura 5: Área de estudo com buffer de 2 km do eixo viário (municípios de São Paulo e Osasco) Elaborado e organizado pela autora

Dados extraídos do IBGE (BRASIL, 1984) 


\subsection{Análise de informações sobre o entorno do Rodoanel Mario Covas}

"As informações com as quais o geógrafo trabalha podem provir de duas fontes principais: documentos cartográficos e estatísticos (fontes secundárias) e de levantamento direto no campo (fonte primária).” (GERARDI e SILVA, 1981, p.11)

Os materiais utilizados foram cartas topográficas do IBGE, Folhas Santana do Parnaíba e Guarulhos com data de edição de 1984, escala 1:50000 e eqüidistância entre as curvas de nível correspondente a 20 metros, fotografias aéreas do ano de $1994^{18}$, imagens de alta resolução IKONOS do ano de $2002^{19}$, documentos cedidos pela empresa DERSA (EIA, AAE), dados disponíveis em documentos públicos (IBGE, SEADE, PDDT) e material referente a revisão bibliográfica.

Os estudos que antecedem a construção de um eixo viário visam obter seu melhor traçado, o que já não ocorre quando sua construção está finalizada. No caso da construção do trecho oeste do Rodoanel Mario Covas, as etapas anteriores à construção para coleta de informações sobre o meio físico como topografia, hidrografia, a fauna, a flora, o solo, bem como coleta de informações de caráter social, foram realizadas pela empresa responsável. Estes estudos resultaram em relatórios como EIA / RIMA que, na análise do entorno do eixo viário já construído, como o Rodoanel Mario Covas, foram estudados como forma de conhecer e obter informações sobre a área. Estes estudos, unidos às informações atualizadas, forneceram base para a caracterização do cenário atual do entorno do eixo viário. Sendo assim, no caso deste trabalho, o ponto de partida para análise da paisagem no entorno do trecho oeste Rodoanel Mario Covas foi o levantamento de informações por meio de entrevista com a empresa responsável (DERSA) e o estudo de documentos cedidos pela própria empresa que apresentam características do uso e ocupação do solo em datas anteriores à construção.

Foram estudados os seguintes documentos para o reconhecimento mais detalhado das alterações decorrentes da implantação do Rodoanel (Tabela V).

\footnotetext{
18 Aerolevantamento 1994. Laboratório de Sensoriamento Remoto e Aerofotogrametria (LASERE), Universidade de São Paulo, Faculdade de Filosofia e Letras e Ciências Humanas. São Paulo, 2006.

${ }^{19}$ Imagem IKONOS 2002. Fundação de Ciência, Aplicações e Tecnologias Espaciais.
} 


\begin{tabular}{|c|c|}
\hline FONTE & $\mathbf{I}$ \\
\hline $\begin{array}{l}\text { Avaliação Ambiental Estratégica - } \\
\text { AAE (DERSA) }\end{array}$ & $\begin{array}{l}\text { Construção do trecho oeste do Rodoanel e ocupação em seu } \\
\text { entorno. }\end{array}$ \\
\hline EIA/RIMA & $\begin{array}{l}\text { Caracterização do entorno do trecho oeste do Rodoanel; } \\
\text { caracterização do trecho oeste do Rodoanel. }\end{array}$ \\
\hline $\begin{array}{l}\text { Análise da evolução das alterações } \\
\text { no uso do solo nas imediações } \\
\text { do trecho oeste do Rodoanel Mario } \\
\text { Covas (Secretaria de Transportes } \\
\text { do Estado de São Paulo) }\end{array}$ & $\begin{array}{l}\text { Evolução do uso e ocupação do solo no entorno do trecho oeste } \\
\text { do Rodoanel Mario Covas: impactos positivos, neutros e } \\
\text { negativos. }\end{array}$ \\
\hline $\begin{array}{l}\text { Análise Temporal da expansão } \\
\text { urbana por imagens LandSat }\end{array}$ & $\begin{array}{l}\text { Crescimento urbano na área de influência do trecho oeste do } \\
\text { Rodoanel Mario Covas }\end{array}$ \\
\hline $\begin{array}{l}\text { Plano Diretor de Desenvolvimento } \\
\text { de Transportes (PDDT) }\end{array}$ & $\begin{array}{l}\text { Rodoanel como política de transportes estadual. } \\
\text { Fluxo de veículos e de cargas no estado de São Paulo. }\end{array}$ \\
\hline $\begin{array}{ll}\begin{array}{l}\text { Agenda } \\
\text { (EMPLASA) }\end{array} & \text { Metropolitana } \\
\end{array}$ & $\begin{array}{l}\text { Diretrizes para ação no território que visam a recuperação de } \\
\text { ações urbanas e correção dos efeitos da ocupação indevida. }\end{array}$ \\
\hline $\begin{array}{l}\text { Atlas Ambiental da RMSP } \\
\text { (Secretaria Municipal do Verde e } \\
\text { do Meio Ambiente da cidade de } \\
\text { São Paulo) }\end{array}$ & Uso e ocupação do solo na RMSP. \\
\hline \begin{tabular}{lll}
\multicolumn{2}{l}{ Plano Diretor } & Municipal da cidade \\
de São & Paulo & (Prefeitura \\
Municipal) & &
\end{tabular} & Diretrizes que estabelecem a organização do território. \\
\hline $\begin{array}{l}\text { Fundação Sistema Estadual de } \\
\text { Análise de Dados (SEADE) }\end{array}$ & $\begin{array}{l}\text { Crescimento populacional; participação nos vínculos } \\
\text { empregatícios na RMSP; extensão territorial de municípios da } \\
\text { RMSP. }\end{array}$ \\
\hline $\begin{array}{l}\text { Instituto Brasileiro de Geografia e } \\
\text { Estatística (IBGE) }\end{array}$ & $\begin{array}{l}\text { Cartas topográficas; dados de crescimento populacional; } \\
\text { características territoriais. }\end{array}$ \\
\hline
\end{tabular}

Para coleta de dados e informações, foi realizada visita e entrevista à empresa DERSA com o Superintendente de Planejamento da Secretaria de Transportes, Milton Xavier, o que permitiu um aprofundamento no que diz respeito à atuação da empresa na dinâmica da rodovia e conhecimento de documentos que reúnem características importantes sobre sua localização e utilização.

Por meio de informações das cartas topográficas de Guarulhos e Santana do Parnaíba IBGE (BRASIL, 1984a, 1984b) foi realizado um levantamento das vilas e bairros localizados na área de estudo: Vila Jaraguá, Recanto dos Humildes, Recanto da Paz, Vila Nova, Vila Sulina, Vila Hungaresa, Jardim Britânia, Jardim Adelfiori, Parque Anhanguera, Vila Sol Nascente, Vila Morada do Sol, Jardim Jaraguá, Vilas Morro Doce I, Morro Doce II, Morro Doce III, Jardim Parque Anhanguera, Vila Santa Cruz; Jardim Ipanema Jardim Esperança, Jardim Itaberaba II, Vila Homero, Jardim Santa Lucrecia, Vila Aurora, Jardim Rincão; Jardim 
Sta Fé. Foi realizado um levantamento sobre os bairros da cidade de São Paulo, Perus e Jaraguá a fim de caracterizar o entorno de $2 \mathrm{~km}$ do trecho oeste do Rodoanel Mario Covas.

As informações advindas das imagens aéreas também é muito importante na decisão do traçado de uma nova rodovia. No caso da rodovia encontrar-se construída e não sendo necessárias novas construções, as imagens aéreas não são mais utilizadas como instrumentos de localização do melhor traçado viário e sim como um instrumento de análise da transformação ocorrida no espaço ocupado e seu monitoramento.

Las imágenes de satélite, com resoluciones espaciales que permiten trabajar a diferentes escalas, no solo añaden información útil em la fase previa a la construcción si no que, además, permiten um seguimiento temporal de la afectación provocada por uma nueva carretera (JORGE, PINEDA, FÉRNADEZ, 2004²0).

A caracterização foi realizada por meio de trabalhos de campo com levantamento fotográfico e entrevistas com moradores; levantamento de informações históricas; análise de documentos públicos já citados anteriormente; análise das cartas topográficas do IBGE (BRASIL,1984); fotografias áreas (1994) e imagem de satélite (IKONOS, 2002).

Foram aplicadas técnicas de sensoriamento remoto e geoprocessamento por meio de um Sistema de Informações Geográficas - SIG, o programa utilizado foi o ArcGis 9.2, para trabalhar com as informações contidas nos documentos, nas imagens aéreas e nas cartas topográficas. As técnicas de georreferenciamento, digitalização e classificação possibilitaram a elaboração de produtos como banco de dados georeferenciados e representações de dados.

Segundo Venturi (2005, p.15),

[...] no processo de produção científica, a escolha das técnicas está, em primeiro lugar, relacionada a natureza do objeto de estudo e sua adequação a ele [...] métodos, técnicas e instrumentos constituem diferentes aspectos de um mesmo processo (científico), ainda que em alguns momentos os separemos para melhor compreender cada uma de suas características e funções. (p.13)

\footnotetext{
${ }^{20}$ As imagens de satélite, com resolução espacial que permite trabalhar com diferentes escalas, não só adiciona informação útil para a fase prévia da construção como permite um acompanhamento temporal do impacto provocado por uma nova estrada (Tradução livre da autora).
} 
Foi possível a interpretação dos elementos do uso e ocupação do solo utilizando técnicas de sensoriamento remoto por meio da imagem IKONOS com resolução de 1 metro ${ }^{21}$ (Figura 6).

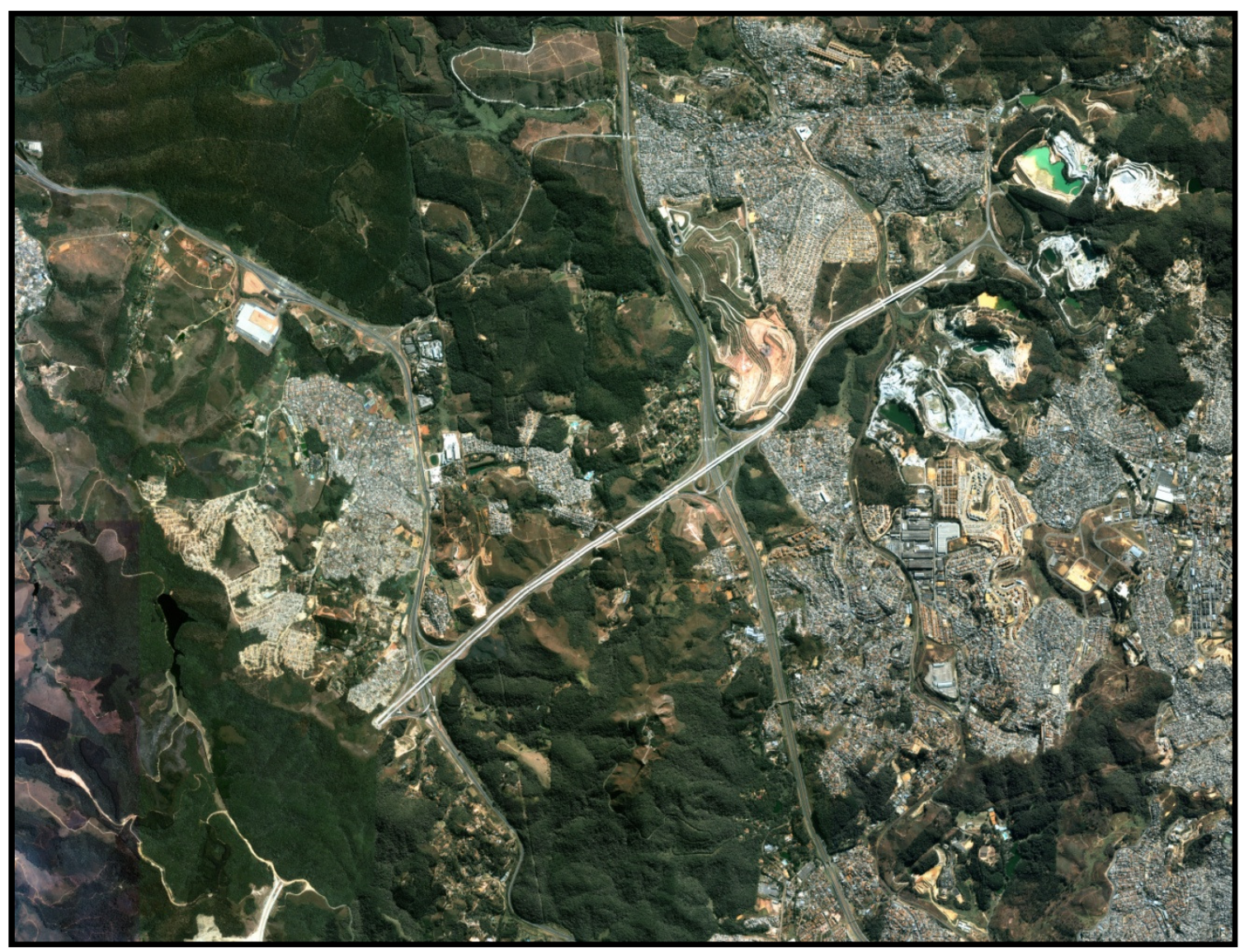

Figura 6: Imagem aérea utilizada para estudo do trecho oeste do rodoanel (municípios de São Paulo e Osasco) Fonte: FUNCATE (2002)

Segundo Bias e Lombardo (2004, p.45) em estudo sobre a imagem IKONOS e precisão cartográfica afirmam que "é possível concluir que as imagens de alta resolução espacial são efetivamente um produto que irá permitir, num futuro próximo, a geração de bases cartográficas em diferentes escalas, atendendo à necessidade de uma infinidade de usuários".

Por meio da imagem IKONOS com data de 2002, foi possível observar ocupações após a construção do trecho oeste do rodoanel. Esta análise foi complementada por trabalhos

\footnotetext{
${ }^{21}$ A resolução espacial mede a separação angular ou linear entre dois objetos (NOVO, 1995).
} 
de campo que permitiram, além de melhor identificar elementos na paisagem, identificar ocupações ainda mais recentes, após o ano de 2002, que não constam na imagem.

As fotografias aéreas utilizadas são datadas de 1994, estão em escala de 1:25.000 e tiveram o objetivo de levantar informações sobre o entorno do Rodoanel nesta data, anterior a construção do Rodoanel. Segundo Moreira (2005,p.213), “as fotografias aéreas podem ser usadas no planejamento de áreas urbanas, no mapeamento dos solos, na cartografia, na identificação de solo etc."

Com a união de produtos de sensoriamento remoto e a utilização do instrumento SIG foi possível obter resultados bem próximos da realidade, complementando de maneira eficaz os dados obtidos nos trabalhos de campo e revisão bibliográfica.

Antes de iniciar o processo de interpretação das imagens, foi realizado o georreferenciamento de acordo com as cartas topográficas do IBGE (BRASIL, 1984) das fotografias aéreas e imagem de alta resolução IKONOS. O programa utilizado foi o ArcGis 9.2 que se mostrou mais adequado para as atividades de armazenar e gerenciar as informações em banco de dados e por possuir bons resultados em seu produto final.

Segundo Glennon et al (2007), o programa ArcGis reduz algumas limitações no processo de elaboração de mapas por meio de banco de dados digital, permitindo o controle sobre como e onde as características em uma base de dados espacial serão descritas em um mapa. Um novo caminho para representação cartográfica foi introduzido, o qual fornece a visualização de dados baseada em regras que define a aparência das características do mapa.

Em um SIG, a análise multitemporal ocorre por meio de sobreposição de imagens, mapas e dados de diferentes datas. Para tanto, numa análise pretérita detalhada foram utilizadas fotografias aéreas do ano de 1994 (figura 7) sobrepostas à imagem IKONOS de 2002 (figura 8). Para a sobreposição foi necessário o georreferenciamento das fotografias aéreas realizada por meio de pontos em comum entre as duas imagens, como edifícios, ruas (esquinas), praças etc., totalizando cerca de 8 a 10 pontos, com margem de erro próximo do valor zero, buscando o ajuste das duas imagens. 


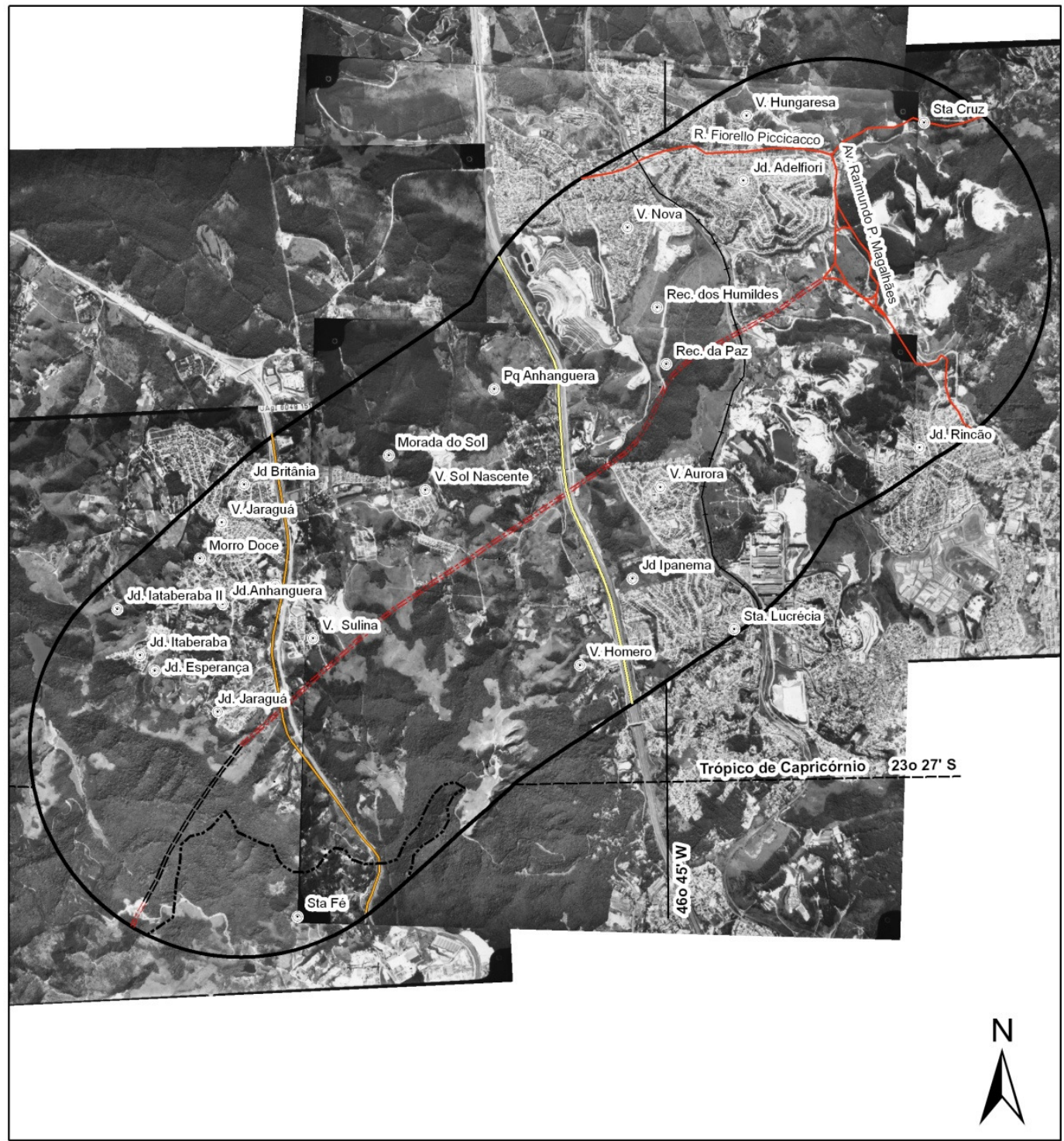

\begin{tabular}{l} 
Legenda \\
$\odot \quad$ Vilas \\
$====$ Traçado do Rodoanel Mario Covas \\
$====$ Traçado do túnel do Rodoanel \\
$\overline{ }$ Rodovia dos Bandeirantes \\
\hline Rodovia Anhanguera \\
\hline Estradas \\
$+\ldots$ Ferrovia \\
$\square$ Divisa municipal \\
\hline Area de estudo
\end{tabular}

Figura 7: Fotos aéreas do ano de 1994 georreferenciadas Elaborado e organizado pela autora Fonte: LASERE (2006) 


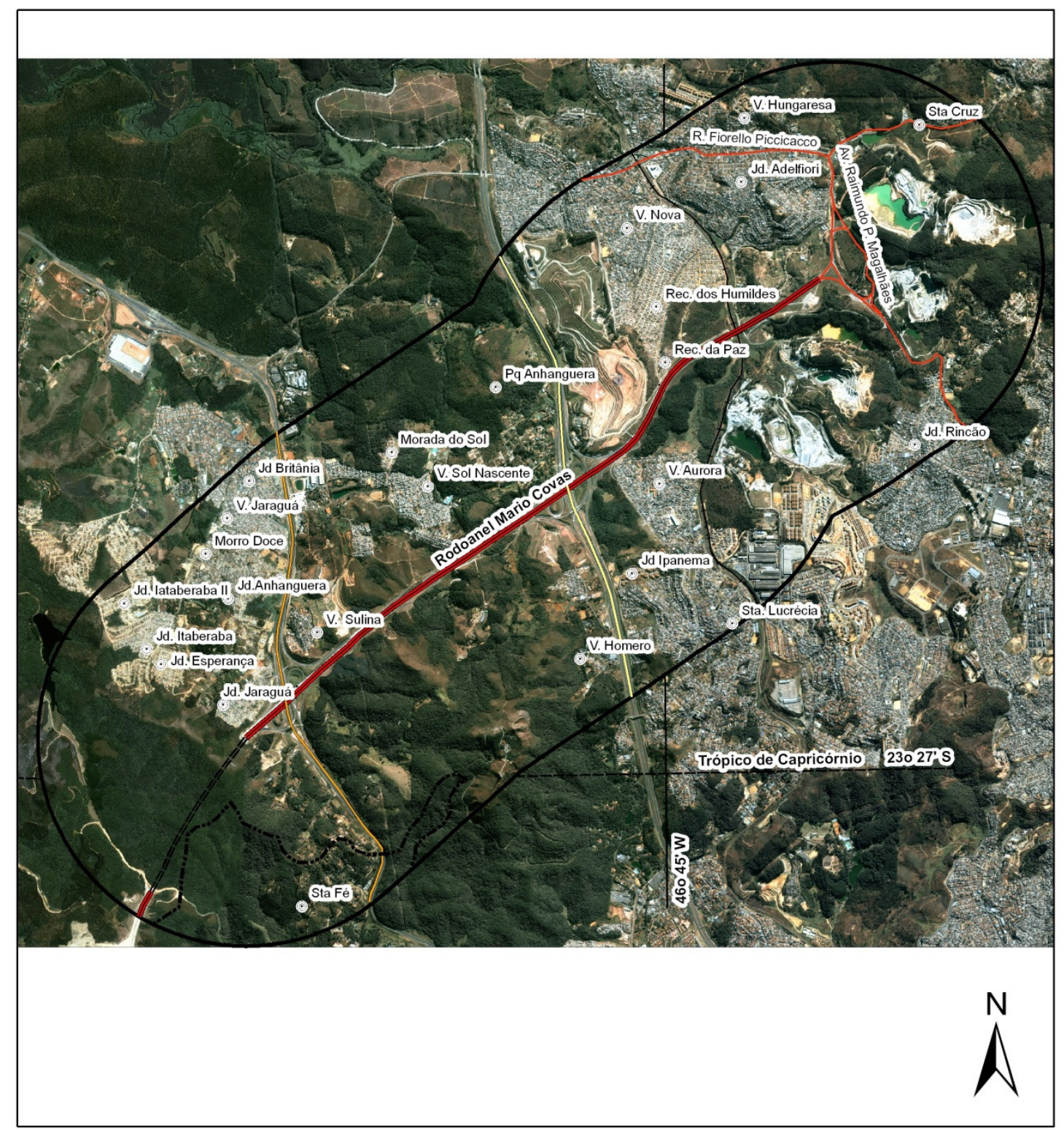

Legenda

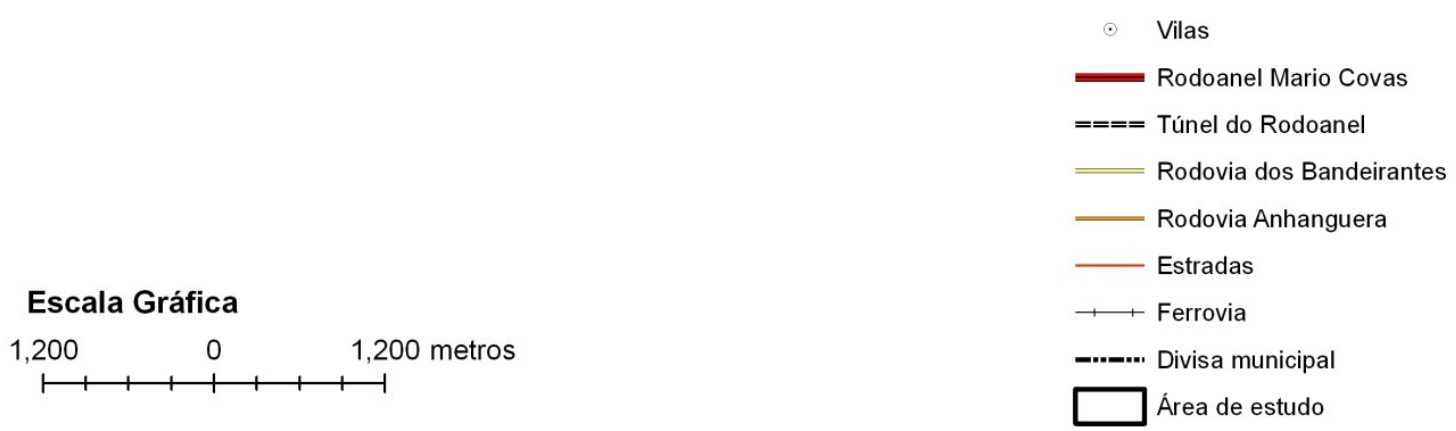

Figura 8: Imagem aérea de alta resolução do ano de 2002 georreferenciada Elaborada e organizada pela autora

Fonte: IKONOS (FUNCATE, 2002) 
As imagens aéreas passaram pelo processo de fotointerpretação, sendo este "o processo em que o intérprete utiliza um raciocínio lógico, dedutivo e indutivo para compreender e explicar o comportamento de cada objeto contido nas fotos" (MOREIRA, 2005, p.214). O processo de interpretação de imagens consiste três fases distintas: a fotoleitura, a foto-análise e a classificação. Segundo Luchiari, Kawakubo e Morato (2005,p.47),

A foto-leitura baseia-se no reconhecimento e no estudo das características de objetos claramente visíveis, representados nas imagens. A segunda fase, a fotoanálise, refere-se às características fundamentais a serem analisadas acerca do tema a se mapeado. A última fase implica a descrição das imagens seguindo uma linha de raciocínio lógico, procurando identificar e delimitar os objetos pelo exame cuidadoso dos elementos.

No processo de foto-leitura, foram analisados os elementos referentes ao uso e ocupação do solo, observando-se na imagem de satélite, arranjos espaciais estudados em trabalho de campo. Para Luchiari, Kawakubo e Morato (2005,p.47)

O padrão caracteriza-se pelo arranjo espacial entre os objetos representados na imagem; a repetição de certas formas é característica de certas paisagens. Dessa forma, o padrão urbano, por exemplo, define-se pelo arruamento, formado por quadras com edificações; nas áreas agrícolas, podem ser edificadas glebas com culturas em diferentes estágios de crescimento e glebas em solo separado.

Após o georreferenciamento foi realizada a foto-leitura e foto-análise das imagens, sendo possível observar as transformações ocorridas, principalmente no entorno das rodovias Anhanguera, Bandeirantes e na área onde foi construído o Rodoanel Mario Covas. Luchiari, Kawakubo e Morato (2005, p.46) afirmam que

A interpretação propriamente dita é realizada com base em elementos constantes em todas as imagens, apesar de, freqüentemente apresentarem-se de forma diferenciada. Os elementos devem ser analisados em conjunto, pois isoladamente não podem traduzir a realidade acuradamente.

Alguns tipos de interpretações citadas por Chuvieco (2002) são: "classificação de coberturas, geração de variáveis ambientais, detecção de transformações" (tradução da autora) $)^{22}$.

22 "Classificación de coberturas; generación de variables ambientales; detección de câmbios classificação de coberturas." 
Após a interpretação e a classificação foi feito o processo de análise temporal com o objetivo de identificar as transformações ocorridas entre 1994 e 2002, sendo que a obra do Rodoanel foi concluída no ano 2000. Segundo Santos (2004, p.54)

A detecção de mudanças se dá pela sobreposição de imagens ou mapas de diferentes datas, nos quais ressaltam-se as diferenças que são reclassificadas para extrair as alterações significativas. Uma maneira de discriminar as mudanças ocorridas entre as imagens é obter uma classificação independente de cada imagem, registrando os resultados e localizando as células que apresentem diferenças. Outra maneira é inscrever as duas imagens no SIG e preparar uma imagem de diferença temporal.

A classificação independente foi realizada nas duas imagens de acordo com a legenda definida de acordo com os dados coletados em trabalhos de campo e pesquisas bibliográficas, e foi criada uma imagem de diferença temporal como sugeriu a autora Santos (2004).

\subsection{Métodos de classificação digital para análise da paisagem urbana no entorno do Rodoanel Mario Covas}

Sendo os produtos de sensoriamento remoto uma representação estática e congelada do espaço, serão as informações sobre o uso e ocupação do solo em diferentes datas que poderão demonstrar, de alguma forma, como ocorreu a dinâmica espacial. Por isso, nas representações gráficas, é muito importante uma análise temporal, isto é, um estudo sobre a transformação ocorrida em uma área em um período.

Existem muitos caminhos de análise a partir da construção de cenários [...] o que se deve destacar é a capacidade de retratar mudanças, seja na estrutura resultante da combinação dos elementos que compõem o meio, seja nas funções e interações desses elementos. É um forte elemento de análise para interpretar os rumos e as velocidades das alterações no espaço, bem como conduzir, tecnicamente, a uma reflexão sobre implicações de projetos e políticas de desenvolvimento (SANTOS, 2004, p.53).

Para a representação do uso e ocupação do solo e análise multitemporal foi necessária a criação de classes buscando envolver "elementos naturais e artificiais" (SANTOS, 1999).

O primeiro processo de classificação foi feito manualmente (classificação analógica), sendo realizado somente com a classe "galpões" na carta topográfica de 1984, e realizado com todas as classes nas fotos aéreas de 1994 e na imagem aérea de 2002. A legenda foi definida 
pelas classes, pelos traçados dos principais eixos viários, corpos d’água e curvas de nível para definição do relevo.

As classes foram utilizadas na análise temporal; os principais eixos viários foram traçados com o objetivos de analisar o uso do solo também em áreas de entroncamentos; os corpos d’água permitem a análise do uso do solo em locais informais e pontos de degradação ambiental; e definição do relevo auxiliaram os trabalhos de campo e a análise do favorecimento do crescimento da mancha urbana por meio do relevo. Todas as informações coletadas e trabalhadas em ambiente SIG foram utilizadas para a geração de produtos como banco de dados georeferenciados e representações gráficas visando o entendimento da dinâmica espacial.

Foi realizada na imagem IKONOS e nas fotografias aéreas, a classificação analógica, onde foi estabelecido o número de classes pelo usuário e atribuída à imagem segundo fotoleitura e foto-análise da imagem (figura 9). As classes criadas foram:

1- Área construída (vilas, casas e galpões)

2- Área verde densa (fragmentos de mata)

3- Gramínea e árvores esparsas (vegetação rasteira e árvores espaçadas)

4- Solo exposto (terrenos ou ruas com solo exposto)

5- Água (lagos e lagoas) 

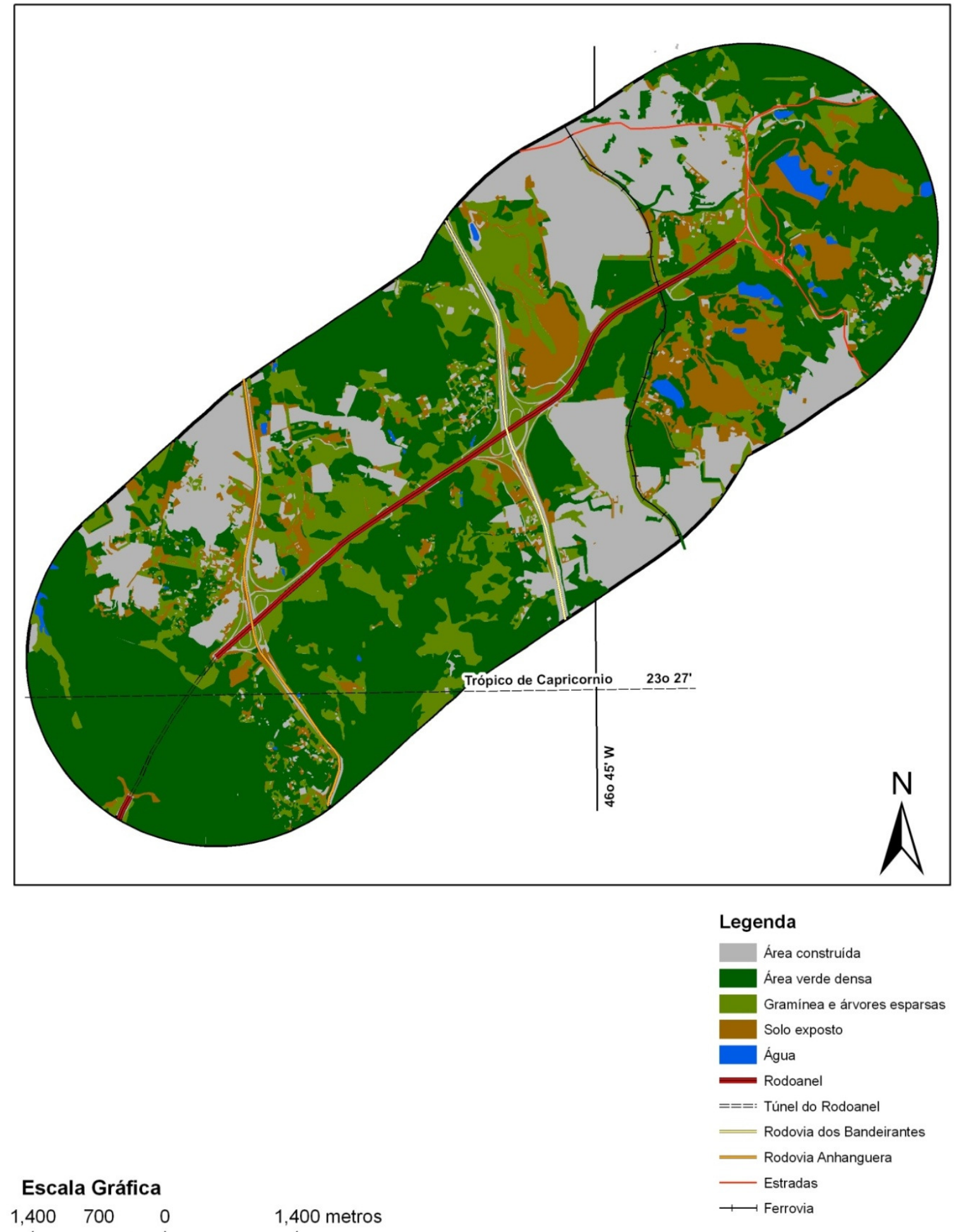

Figura 9: Classificação analógica na imagem IKONOS do ano de 2002 Elaborado e organizado pela autora

Programa ArcGis 9.2 
No processo de elaboração de mapas, um cartógrafo possui a liberdade de escolher o índice, cores, símbolos, escala e características espaciais para relação e comunicação dos mapas propostos. Tradicionalmente, as formalidades do banco de dados espacial digital limitaram a flexibilidade de criar um mapa que combinasse com a visão do cartógrafo"23 (GLENNON, R. e GLENNON, J., 2007, p. 59) (tradução da autora).

Na imagem IKONOS foi feita a classificação automática, onde o SIG atribuiu classes automaticamente à imagem, sem a coleta de amostras pelo usuário (não supervisionada) ou com a coleta de amostras (supervisionada).

As classes criadas na classificação automática sofreram algumas modificações, pois não foi possível a identificação de algumas áreas, como água, por exemplo, por serem muito distintas (ex: água de piscinas tem a cor azul clara; água de lagos tem a cor cinza escura; água de lagoas em áreas de mineração assoreadas possuem cores em tonalidade marrom). Na classificação automática foi possível estabelecer áreas com sombra, o que não foi possível estabelecer no modo analógico por estarem muito próximas às outras classes e não permitirem distinção na visibilidade. As classes definidas na classificação automática foram:

$$
\begin{aligned}
& 1 \text { - Área construída (vilas, casas e galpões) } \\
& 2 \text { - Área verde densa (fragmentos de mata) } \\
& 3 \text { - Área verde esparsa (vegetação rasteira e árvores espaçadas) } \\
& 4 \text { - Solo exposto (terrenos ou ruas com solo exposto) } \\
& 5 \text { - Sombra (sombra de árvores ou construções) } \\
& 6 \text { - Nenhum (nenhuma das classes acima) }
\end{aligned}
$$

Segundo Hamburger e Foresti (1997, p.23-24)

É preciso que um estudo de classes de uso do solo urbano por sensoriamento remoto considere os materiais com características espectrais próprias componentes de cada classe de uso (incluindo-se as sombras) a área ocupada na classe por cada uma destas unidades, sua distribuição espacial e finalmente, que estas informações sejam ponderadas de acordo com a resolução espacial do sensor em questão. No caso nas imagens orbitais surge a necessidade de definir tipos de ocupação com zonas homogêneas e de verificar nas imagens orbitais as feições que as caracterizam.

\footnotetext{
${ }^{23}$ In the mapmaking process, a cartographer has the freedom to choose the content, colors, symbols, scale, and position of spatial features to convey meaning and communicate the map's purpose. Traditionally, the rigid locations and formalities of a digital spatial database have limited flexibility in creating a map that matches the cartographer's vison.
} 
Ao todo foram realizados cinco testes, sendo três classificações supervisionadas e duas classificações não supervisionadas por regiões ${ }^{24}$ (tabela VI).

Tabela VI: Classificadores do programa Spring

\begin{tabular}{|c|c|c|}
\hline Classificador (nome) & Tipo de análise & Tipo de treinamento \\
\hline Isoseg & regiões & Não supervisionado \\
\hline Bhattacharya & regiões & Supervisionado \\
\hline \multicolumn{3}{|c|}{$\begin{array}{c}\text { Fonte: Tutorial SPRING, 2002 } \\
\text { Organizado pela autora }\end{array}$}
\end{tabular}

A área de estudo foi dividida em 5 partes semelhantes e os testes foram feitos em apenas uma destas partes contendo todas as classes necessárias para a avaliação do processo mais adequado. A imagem IKONOS foi tratada com manipulação de contraste antes de iniciar o processo de segmentação e classificação.

A manipulação do contraste de imagem tem como objetivo melhorar a sua qualidade visual sob critérios subjetivos ao olho humano [...] é normalmente utilizada como uma etapa de pré-processamento para sistemas de reconhecimento de padrões (TUTORIAL SPRING, 2002).

A segmentação é um processo anterior a classificação e consiste em agrupar os pixels por regiões. Segundo Instituto Nacional de Pesquisas Espaciais - INPE (2002) "Entende-se por região um conjunto de pixels contíguos, que se espalham bidirecionalmente e que apresentam uniformidade espectral". (figura 10)

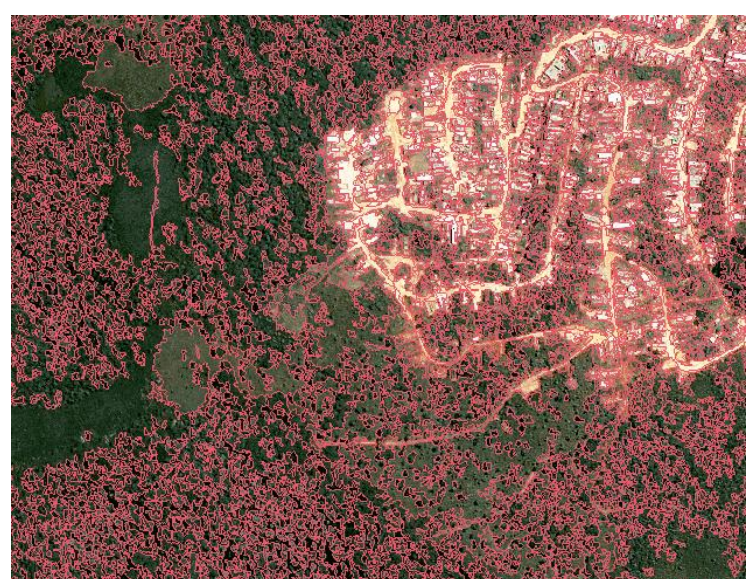

Figura 10: Imagem segmentada (Spring 4.3.3)

Segmentação realizada pela autora

Fonte: FUNCATE (2002)

\footnotetext{
24 “As técnicas de classificação podem ser divididas em classificadores por pixel ou regiões, sendo por pixel a utilização espectral de cada pixel isolados pra achar regiões homogêneas, enquanto que por regiões baseiam-se em um conjunto de pixels vizinhos" (INPE, 2002).
} 
A classificação é o processo de extração de informação em imagens para reconhecer padrões e objetos homogêneos. O resultado final de um processo de classificação é uma imagem onde cada pixel contém a informação de uma classe, ou tema, associada ao ponto de uma cena correspondente (TUTORIAL SPRING, 2002).

Os processos de segmentação e classificação foram realizados no programa Spring 4.3.3 (SPRING, 1996), SIG que mostrou-se adequado para a realização destas atividades. Dos testes executados, foi escolhido o que mais apresentou resultados próximos a fotointerpretação da imagem e aos trabalhos de campo (Tabela VII e Figura 11). Para o processo de classificação foi criada uma categoria no modelo imagem. É uma forma de organizar o banco de dados do SIG, pois a categoria criada é capaz de armazenar dados de imagem (no caso, produtos com extensão TIF).

\begin{tabular}{|c|c|c|c|c|c|}
\hline \multicolumn{6}{|c|}{ Tabela VII: Dados referentes à classificação automática supervisionada } \\
\hline \multicolumn{6}{|c|}{ CATEGORIA CRIADA: IMAGEM } \\
\hline $\begin{array}{c}\text { Imagem } \\
(\mathbf{R}, \mathbf{G}, \mathbf{B})\end{array}$ & Projeção & Classificador & Treinamento & $\begin{array}{l}\text { Limiar de } \\
\text { aceitação }\end{array}$ & Análise \\
\hline Sintética & UTM/WGS84 & Bhattacharya & Supervisionado & $75 \%$ & regiões \\
\hline
\end{tabular}



Figura 11: Exemplo de classificação automática supervisionada por regiões Bhattacharya $75 \%$ Elaborado pela autora

As classes foram pré-definidas antes dos processos de segmentação e classificação, sendo organizadas dentro de uma categoria específica para modelos temáticos. No processo de classificação foram coletadas amostras para o programa classificar a imagem de acordo com os pontos de amostras. Foram criadas 7 classes pelo programa, e foram reduzidas a 6 
classes pela autora. $\mathrm{O}$ banco de dados contendo estas classes foram exportadas para outro SIG (ArcGis 9.2) para a elaboração do mapa temático, sendo feita então, a legenda definitiva (figuras 12 e 13).

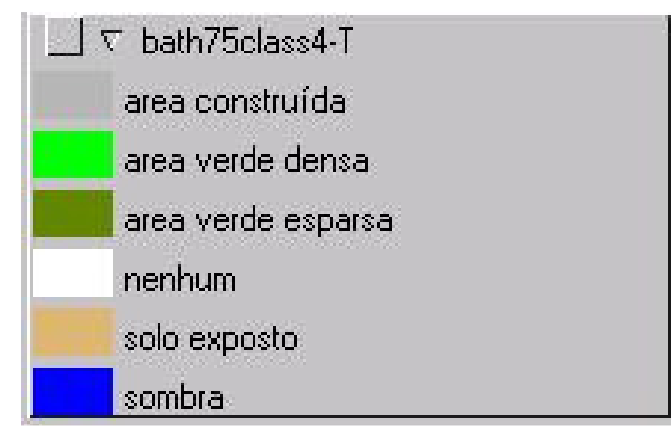

Figura 12: Classes atribuídas pela autora após a classificação automática supervisionada (Spring)

\section{Legenda}

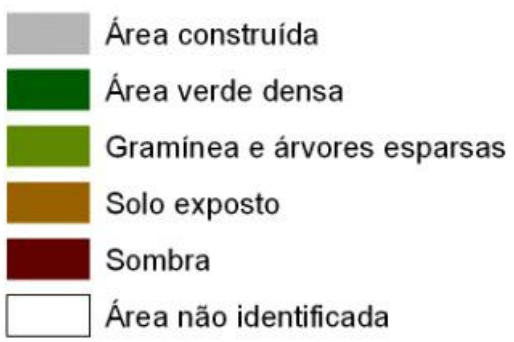

Figura 13: Elaboração da legenda após exportação de dados (ArcGis)

Elaborado e organizado pela autora

Fonte: IKONOS (FUNCATE, 2002)

No caso da classificação automática supervisionada, para se coletar áreas amostrais na imagem visando a criação de classes e da legenda é preciso que o usuário observador tenha conhecimento da área estudada, é o que a autora Pinho (2006) chama de "sistemas baseados em conhecimento".

O funcionamento destes sistemas baseia-se na introdução do conhecimento do analista a respeito da cena, ou seja, é uma formalização da "visão" de um determinado indivíduo sobre uma cena específica. Assim, o resultado da classificação é um reflexo do conhecimento (informações coletadas a priori sobre a área a ser classificada) e da capacidade de compreensão do analista (fortemente influenciada por sua formação profissional e experiência) a respeito de uma determinada cena (PINHO, 2006, p.41)

Posteriormente, as classes são analisadas para se avaliar os erros do processo e são determinadas novas classes pré-definidas pelo usuário substituindo aquelas criadas pelo programa (Figura 14). 


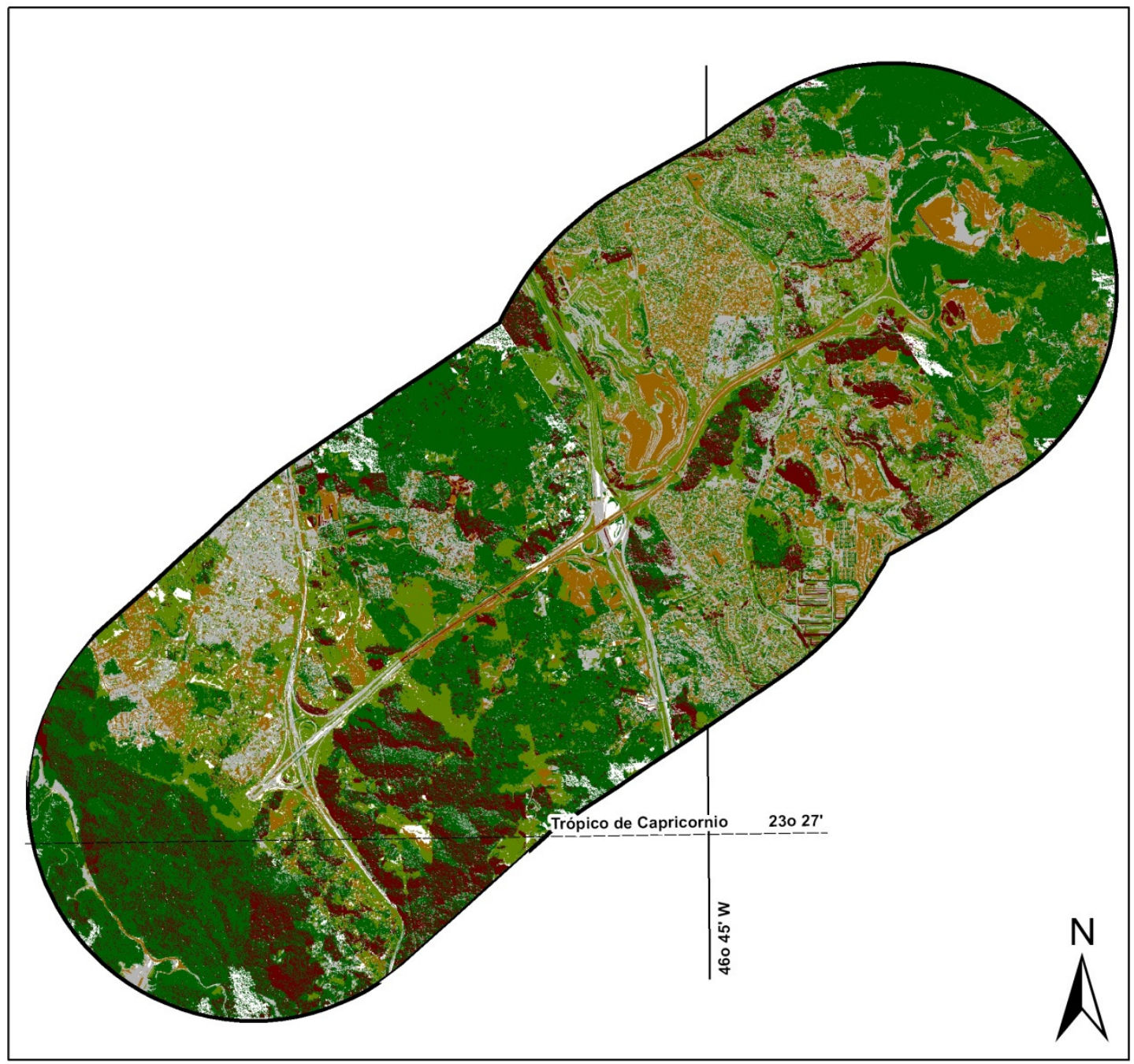

\section{Legenda}

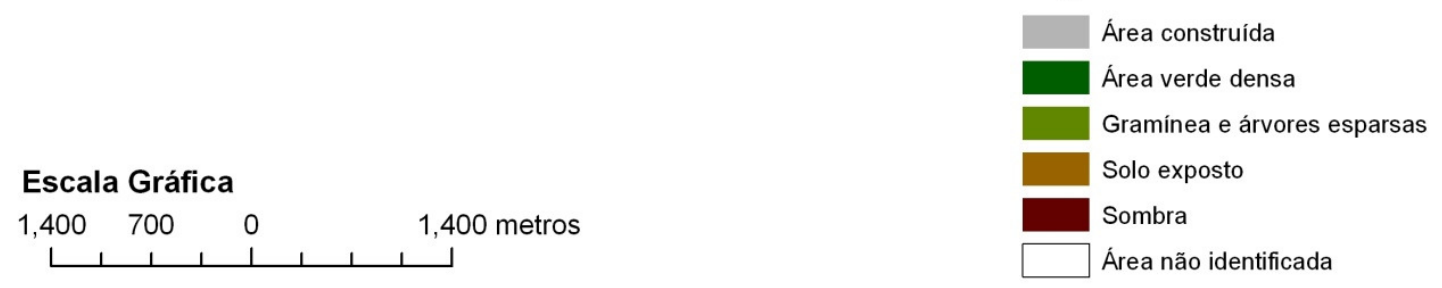

Figura 14: Classificação automática na imagem IKONOS do ano de 2002 Elaborado e organizado pela autora

Programa Spring 4.3.3 
O banco de dados contendo informações sobre a classificação automática supervisionada foi exportado e trabalhado no programa ArcGis 9.2 que mostrou-se mais adequado para esta atividade.

A realização da análise multitemporal foi possível por meio da classificação analógica nos anos de 1994 e 2002. Não foi realizada esta análise por meio de classificação automática, pois não foi possível realizá-las com as fotografias aéreas de 1994 pela baixa resolução da imagem. 


\section{DISCUSSÃO DOS RESULTADOS}

O geógrafo, como todos os cientistas da natureza e da sociedade, lida com informações percebidas concretamente, de natureza qualitativa ou quantitativa. Com o advento da utilização de técnicas estatísticas pela Geografia, a codificação de informações qualitativas em números ou categorias passou a ter importância fundamental e, mesmo aqueles que vêem com restrições a análise quantitativa têm, vez por outra, necessidade de demonstrar suas colocações através de números (brutos, porcentagens, proporções etc.) que, por simples que sejam, não deixam de ser quantificação (entendida aqui como técnica, meio e não como fim em si mesma). (GERARDI e SILVA, 1981, p.11, grifo da autora).

\subsection{Análise temporal da paisagem urbana de 1994 a 2002 por meio de geotecnologias e imagens aéreas}

O banco de dados georeferenciado da classificação analógica do ano de 1994 foi comparado ao banco de dados georeferenciado da classificação analógica do ano de 2002, resultando nos mapas temáticos de análise temporal:

- Áreas Verdes Densas: presença de fragmentos de mata no ano de 1994, no ano de 2002 e as áreas existentes nas duas datas (Figura 15). Caracterizam-se normalmente por fragmentos de mata e áreas de proteção como o Parque do Pico do Jaraguá.

- Gramínea e Árvores Esparsas (Figura 16): presença de vegetação rasteira e árvores espaçadas no ano de 1994, no ano de 2002 e as áreas existentes nas duas datas;

- Solo Exposto (Figura 17): presença de solo exposto nos anos de 1994, no ano de 2002 e as áreas existentes nas duas datas. As maiores áreas de solo exposto são as cavas de mineração, seguidas de ruas não asfaltadas em vilas carentes e terrenos erodidos.

- Áreas Construídas: presença de construções no ano de 1994, no ano de 2002 e as áreas existentes nas duas datas (Figura 18). Caracterizam-se principalmente pelas vilas residenciais;

- Galpões: presença de galpões nos anos de 1984, 1994 e 2002 (Figura 19). Vale ressaltar que o mapeamento de 1984 foi possível devido a detecção da presença de galpões nas cartas topográficas do IBGE (BRASIL, 1984). Trata-se, na maioria dos casos, de galpões industriais, mas há também escolas e supermercados.

Estes resultados foram obtidos devido ao gerenciamento de dados georeferenciados em ambiente SIG. 

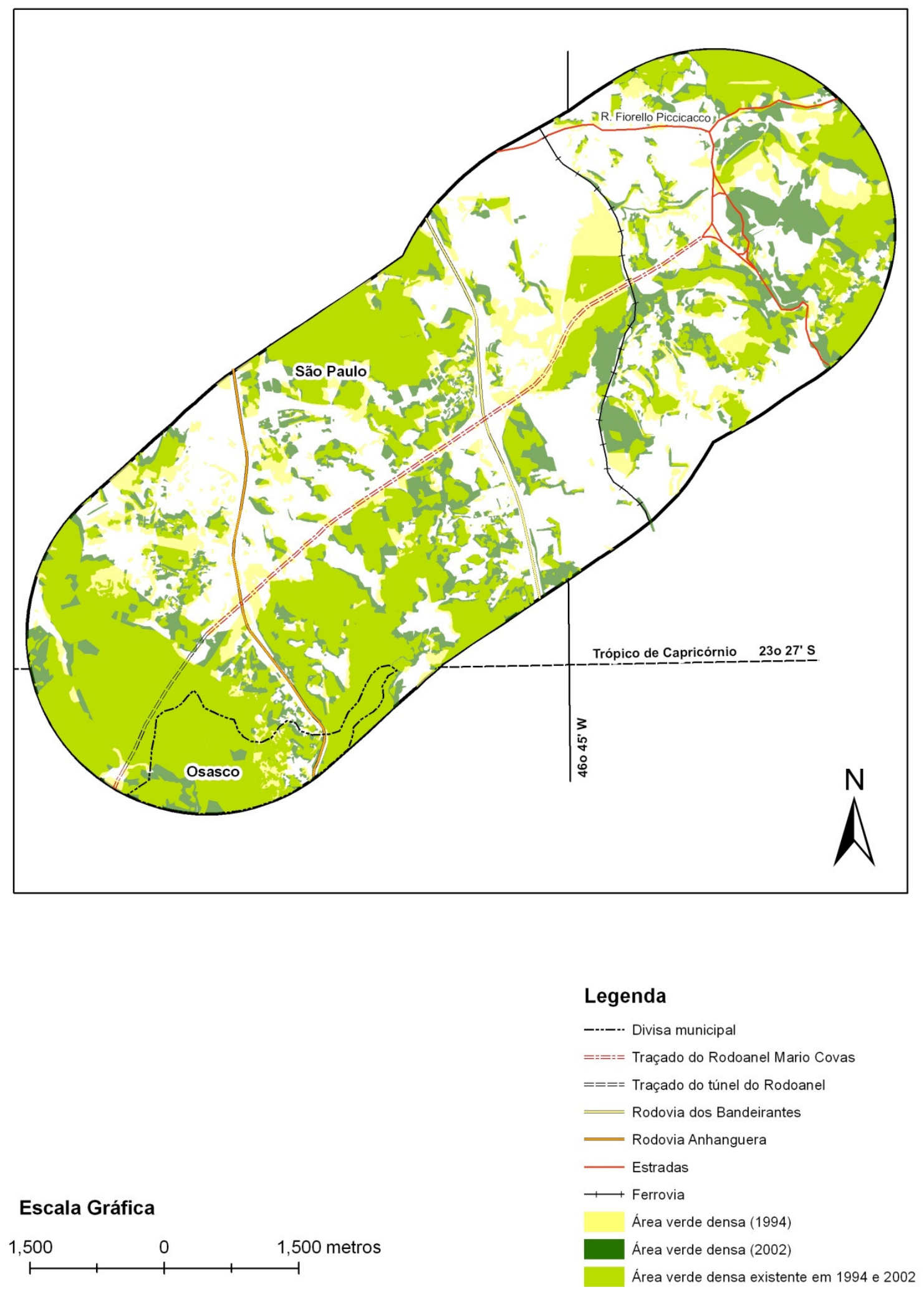

Figura 15: Presença de área verde densa em 1994 e 2002

Organizado e elaborado pela autora

Fonte: LASERE (1994) e FUNCATE (2002)

São Paulo 




\section{Legenda}

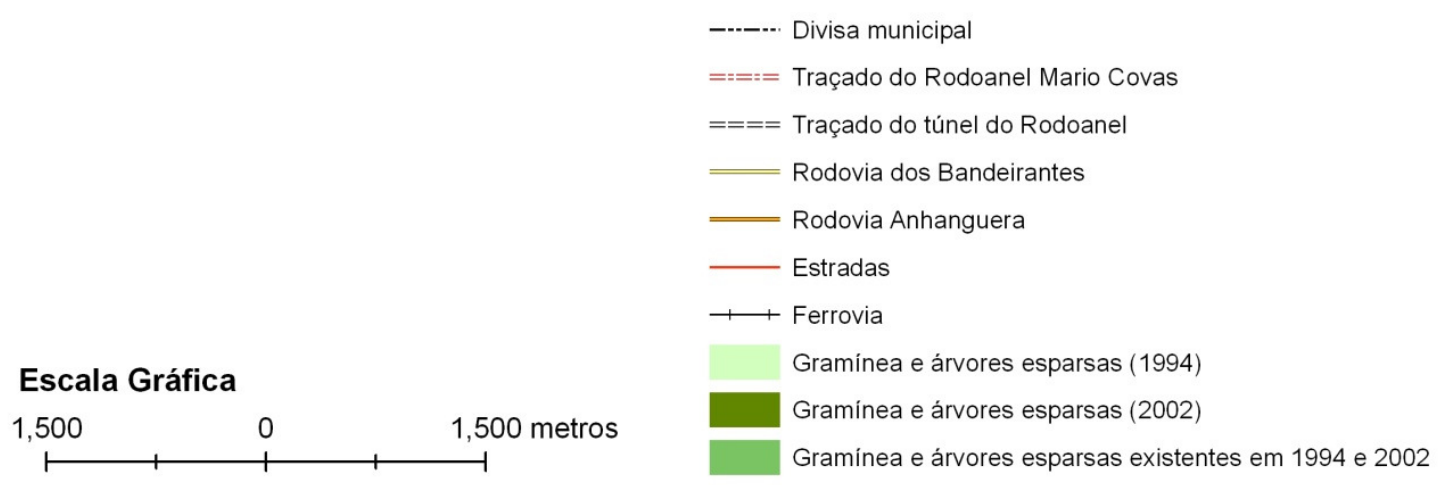

Figura 16: Presença de gramíneas e árvores esparsas em 1994 e 2002

Organizado e elaborado pela autora

Fonte: LASERE (1994) e FUNCATE (2002) 


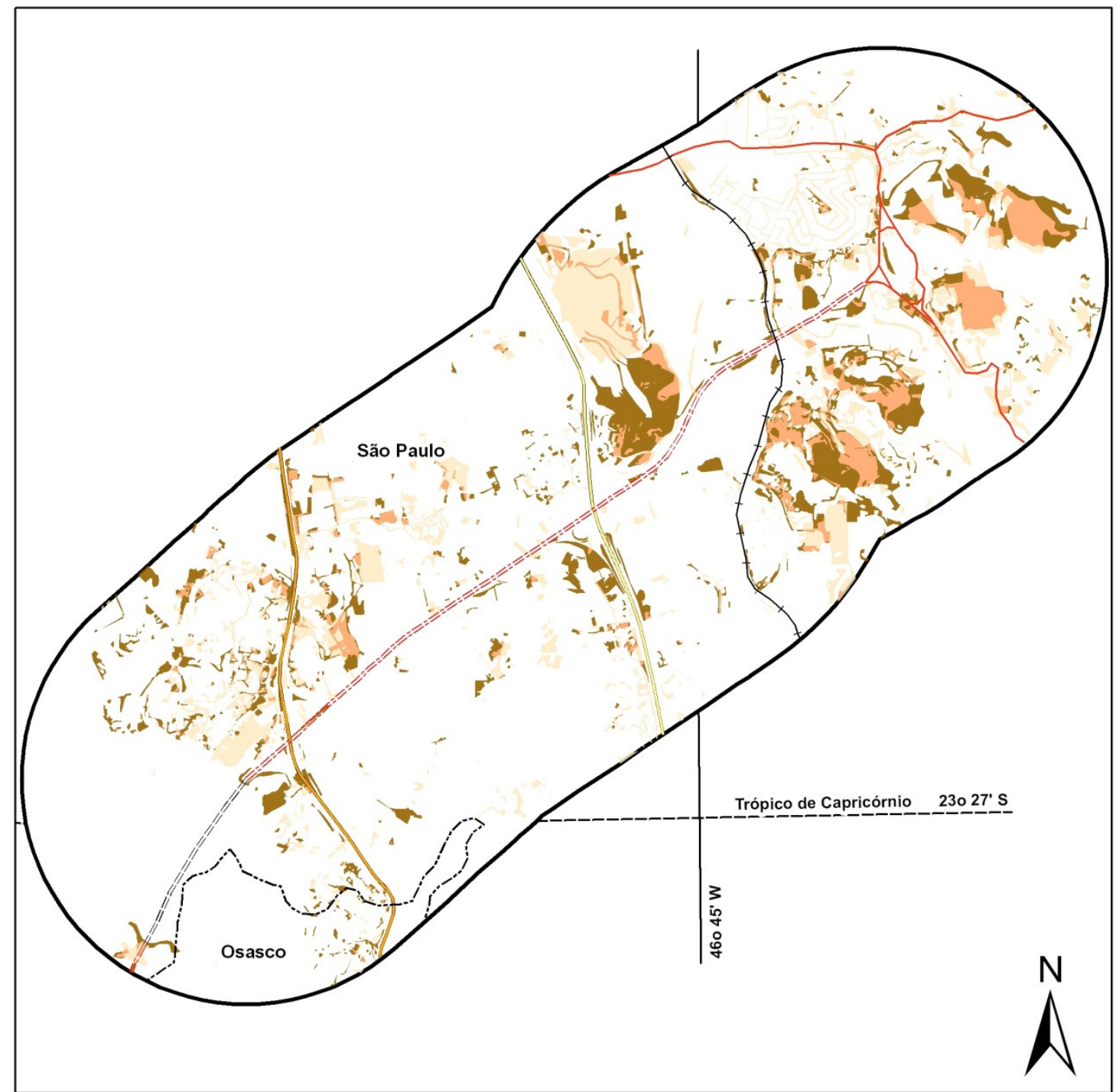

\section{Legenda}

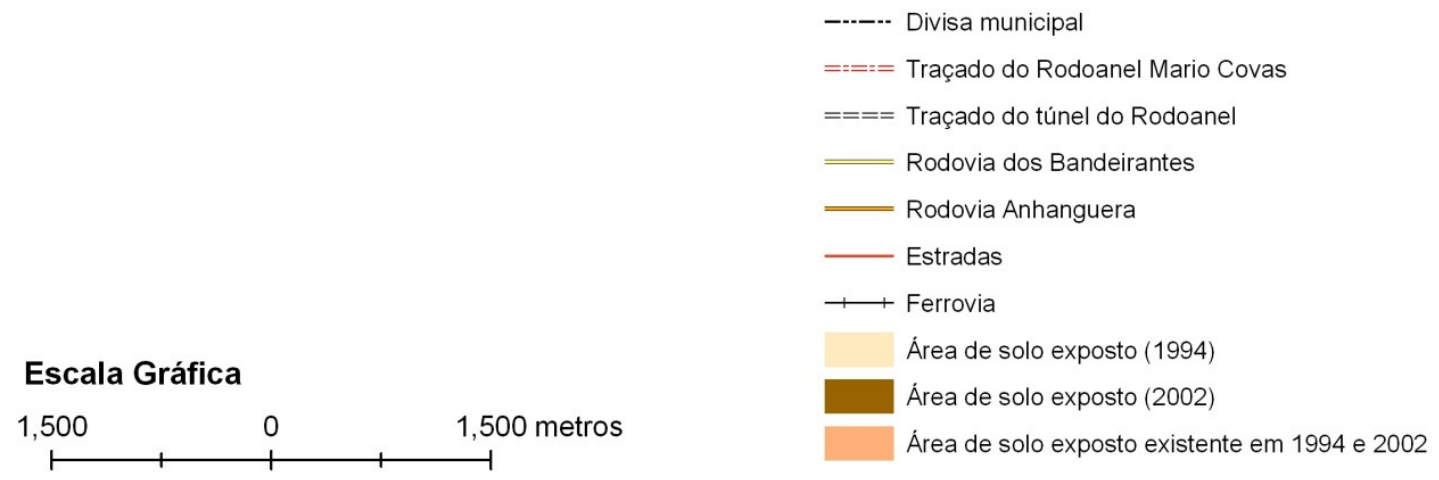

Figura 17: Presença de solo exposto em 1994 e 2002

Organizado e elaborado pela autora

Fonte: LASERE (1994) e FUNCATE (2002) 


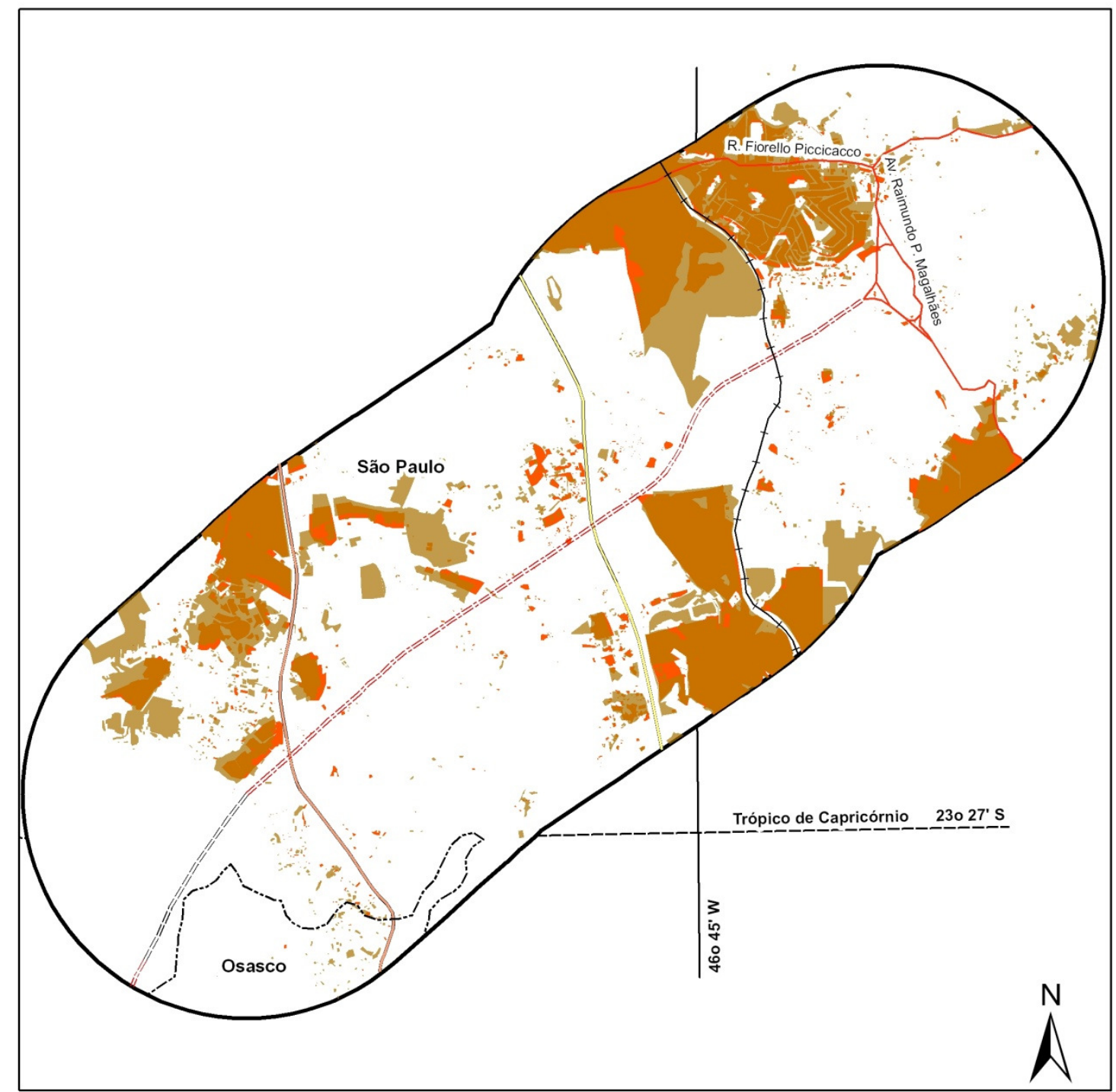

\section{Legenda}

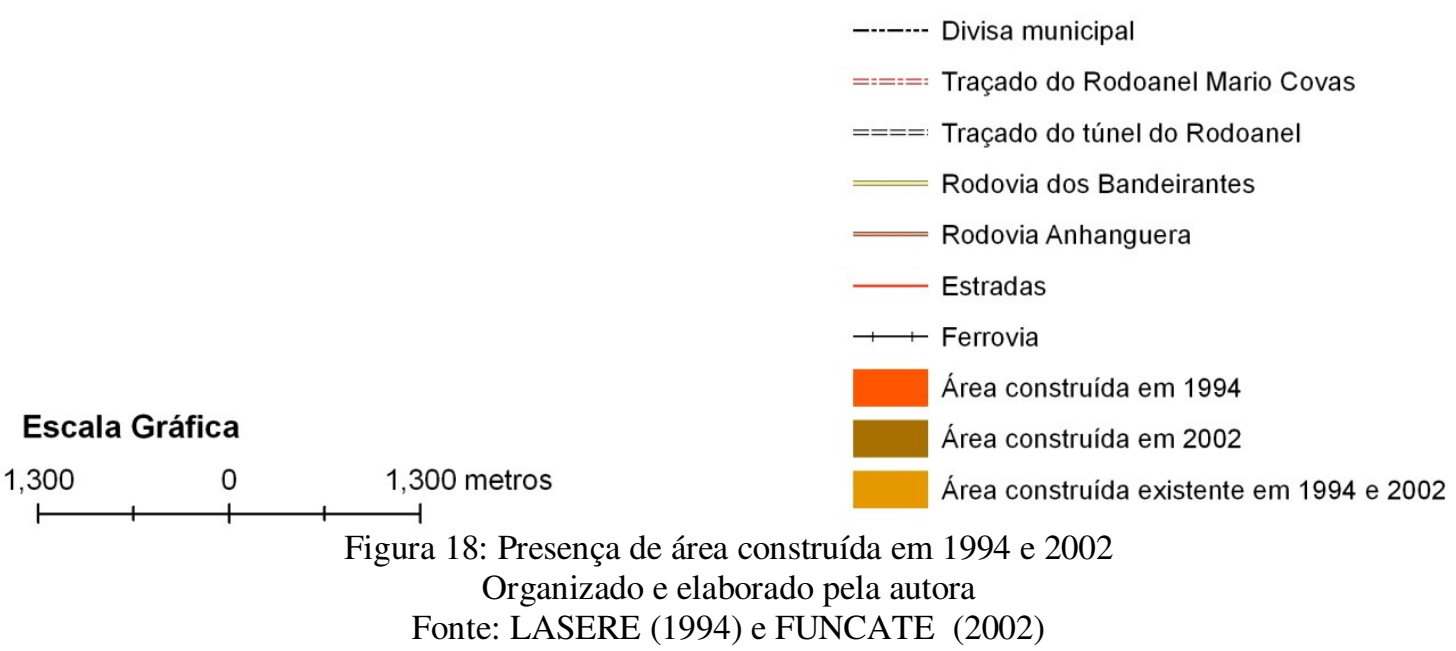

São Paulo 

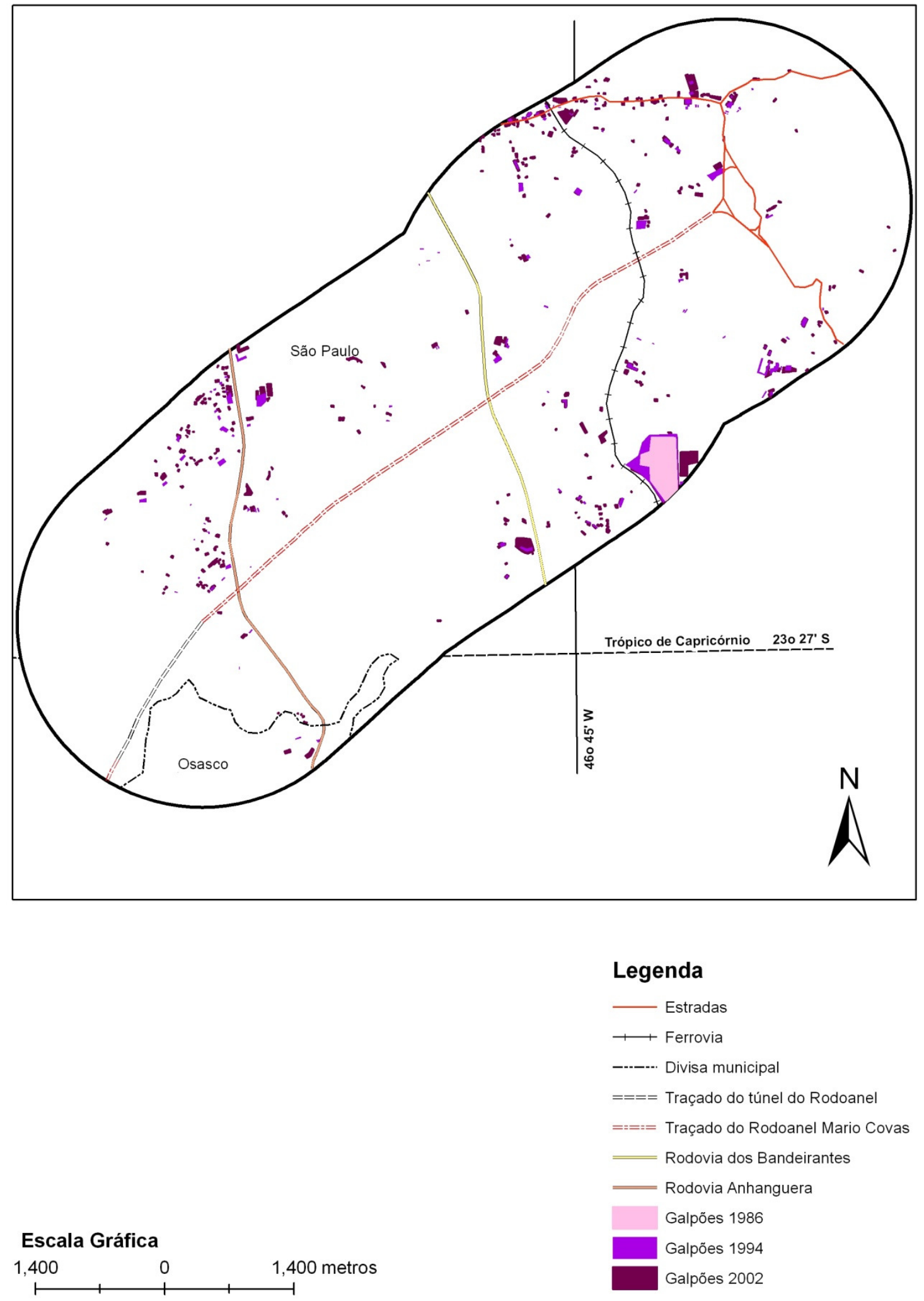

Figura 19: Presença de galpões em 1994 e 2002

Organizado e elaborado pela autora

Fonte: LASERE (1994), FUNCATE (2002), IBGE (BRASIL, 1984) 
A visualização torna-se mais nítida na classificação analógica por se tratar de áreas menos detalhadas, isto é, não considera pequenas regiões. Segundo Pereira et al (2005)

A classificação automática apresenta menor números de variáveis na separação dos alvos quando comparada com a manual que considera maior quantidade de elementos na separação das classes de uso, tais como: tamanho, cor, forma, localização e relações dos alvos com os arredores.

$\mathrm{Na}$ análise temporal, resultante da classificação analógica em uma área de estudo de 41.787.861 $\mathrm{m}^{2}$, foram levantadas as seguintes informações:

A área verde densa cobria cerca de 47,33\% da área de estudo em 1994 e passou a cobrir cerca de 51,46\% no ano de 2002 (Gráfico IV).

Gráfico IV: Quantidade em $\mathrm{m}^{2}$ de área verde densa na área de estudo

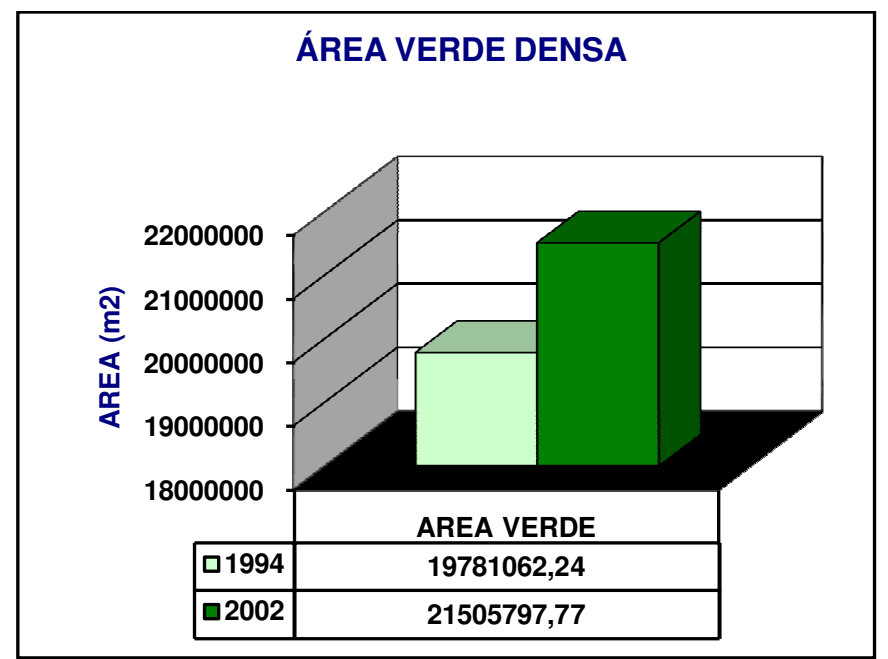

Elaborado e organizado pela autora

Este aumento de área verde densa deve-se a baixa nitidez das fotografias aéreas de 1994 em algumas áreas. Sobretudo, nota-se que, em alguns trechos, como por exemplo, no entorno da linha férrea, onde havia vegetação rasteira (gramínea e árvores esparsas) (Figura 20), no ano de 2002 foi verificado o real aumento de árvores e vegetação mais alta (Figura 21); nas proximidades do entroncamento do Rodoanel com a rodovia dos Bandeirantes também há áreas onde, no ano de 1994, não havia vegetação alta e árvores (Figura 22) e no ano de 2002 foi verificada esta mudança (Figura 23). 




Figura 20: Gramínea e árvores esparsas na fotografia aérea do ano de 1994 ao lado da linha férrea

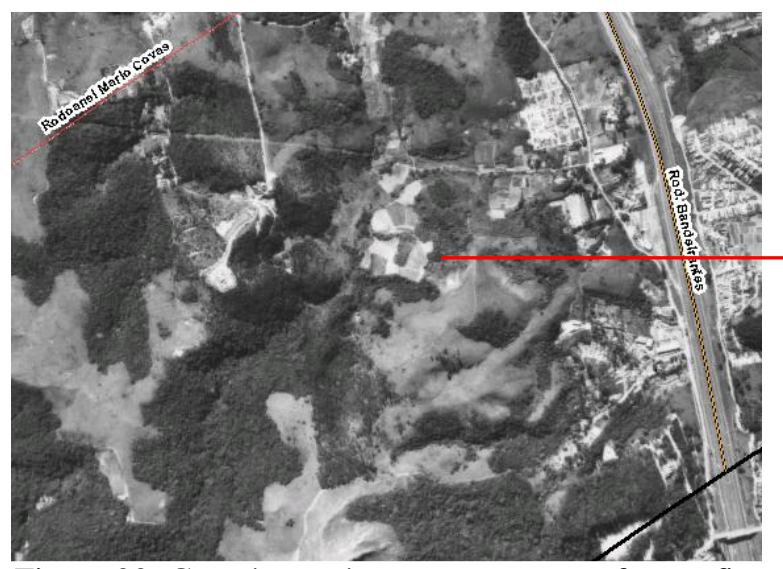

Figura 22: Gramínea e árvores esparsas na fotografia aérea do ano de 1994 próxima a Rodovia dos Bandeirantes

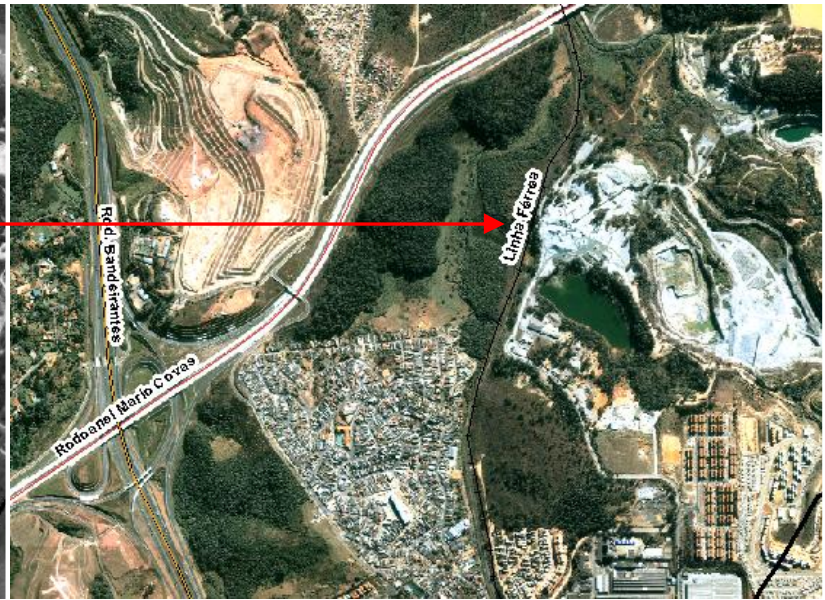

Figura 21: Árvores e vegetação alta na imagem do ano de 2002 ao lado da linha férrea

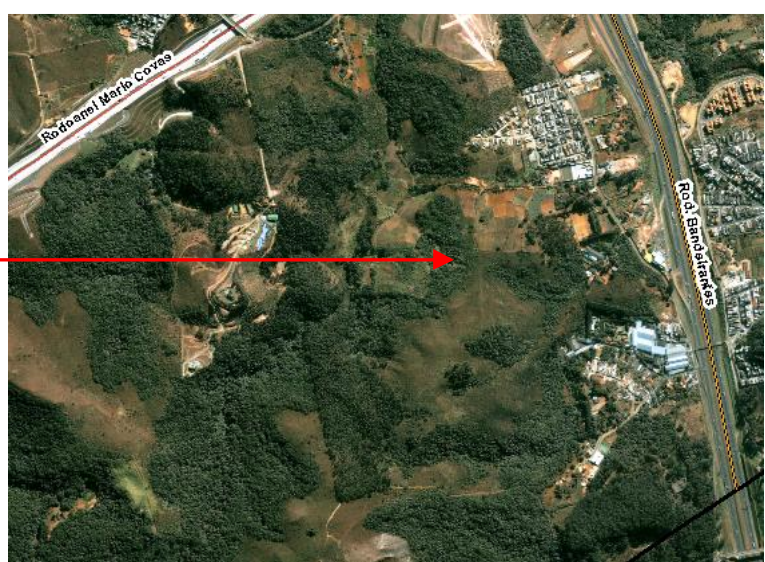

Figura 23: Árvores e vegetação alta na imagem do ano de 2002 próxima a rodovia dos Bandeirantes

Organização da autora

Fonte: LASERE (1994) e FUNCATE (2002)

Devido a fatores como estes, foi registrado um aumento no que aqui denomina-se áreas verdes densas.

A área de gramínea e árvores esparsas ocupava cerca de $28,83 \%$ da área no ano de 1994, diminuindo para 17,29\% no ano de 2002 (Gráfico V). 
Gráfico V: Quantidade em $\mathrm{m}^{2}$ de gramínea e árvores esparsas na área de estudo

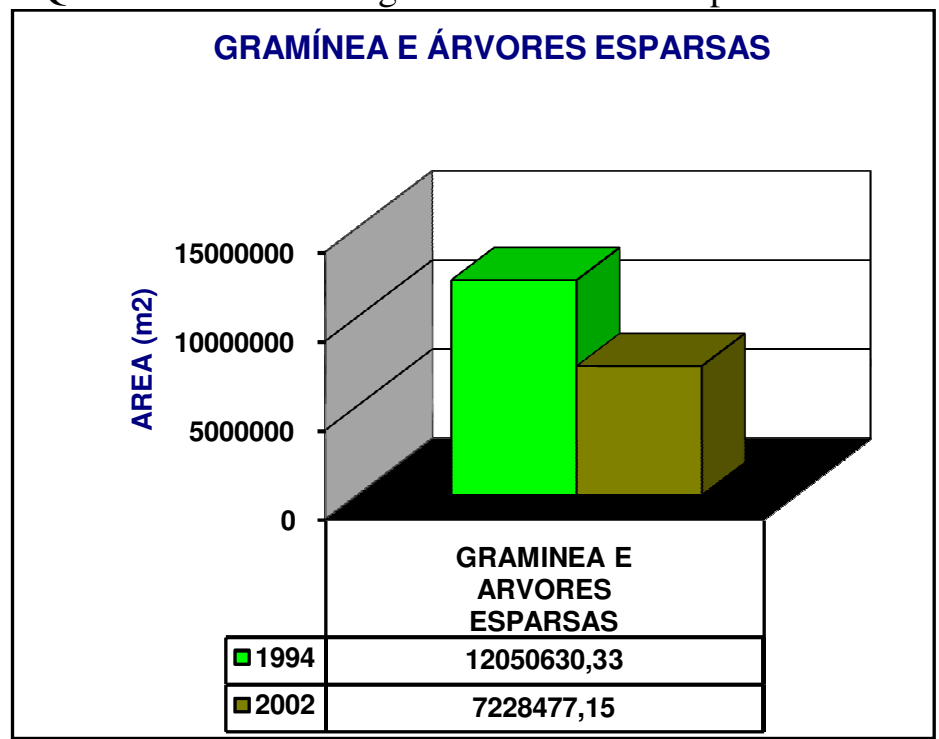

Elaborado e organizado pela autora

A área de gramínea e árvores esparsas foi ocupada, na maioria das vezes, por construções residenciais (figuras 24 e 25).

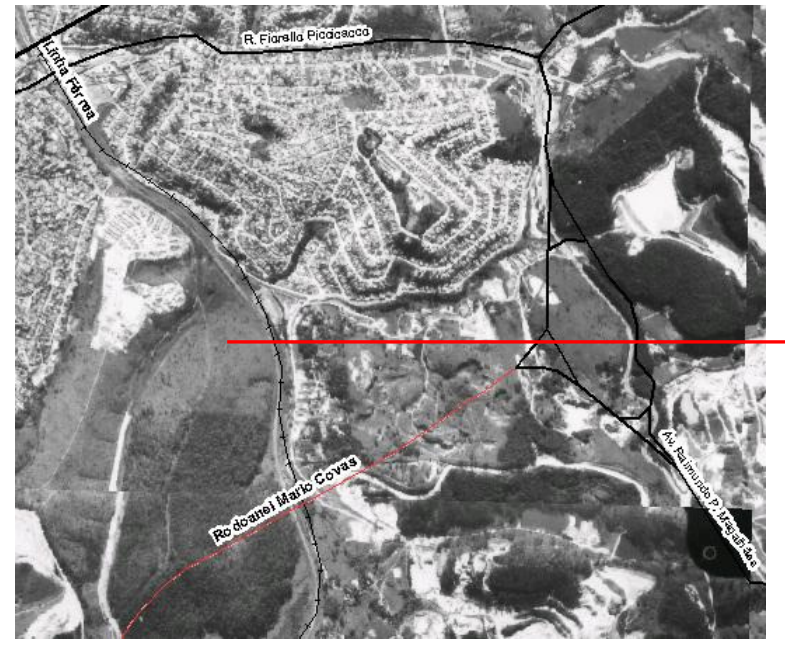

A

Figura 24: Gramínea na fotografia aérea do ano de 1994 próxima a linha férrea e ao futuro traçado do Rodoanel



Figura 25: Área construída na imagem do ano de 2002 próxima a linha férrea e ao Rodoanel.

Elaborado e organizado pela autora

Fonte: LASERE (1994) e FUNCATE (2002) 
A área de solo exposto ocupava cerca de 10,42\% da área no ano de 1994, diminuindo para 9,39\% em 2002 (Gráfico VI).

Gráfico VI: Quantidade em $\mathrm{m}^{2}$ de solo exposto na área de estudo



Elaborado e organizado pela autora

A diminuição da área de solo exposto deve-se à ocupação residencial como a expansão de vilas residenciais (Figura 26a) e também casos de readequação ambiental como o ocorrido em parte do aterro sanitário de Perus (Figura 26b).

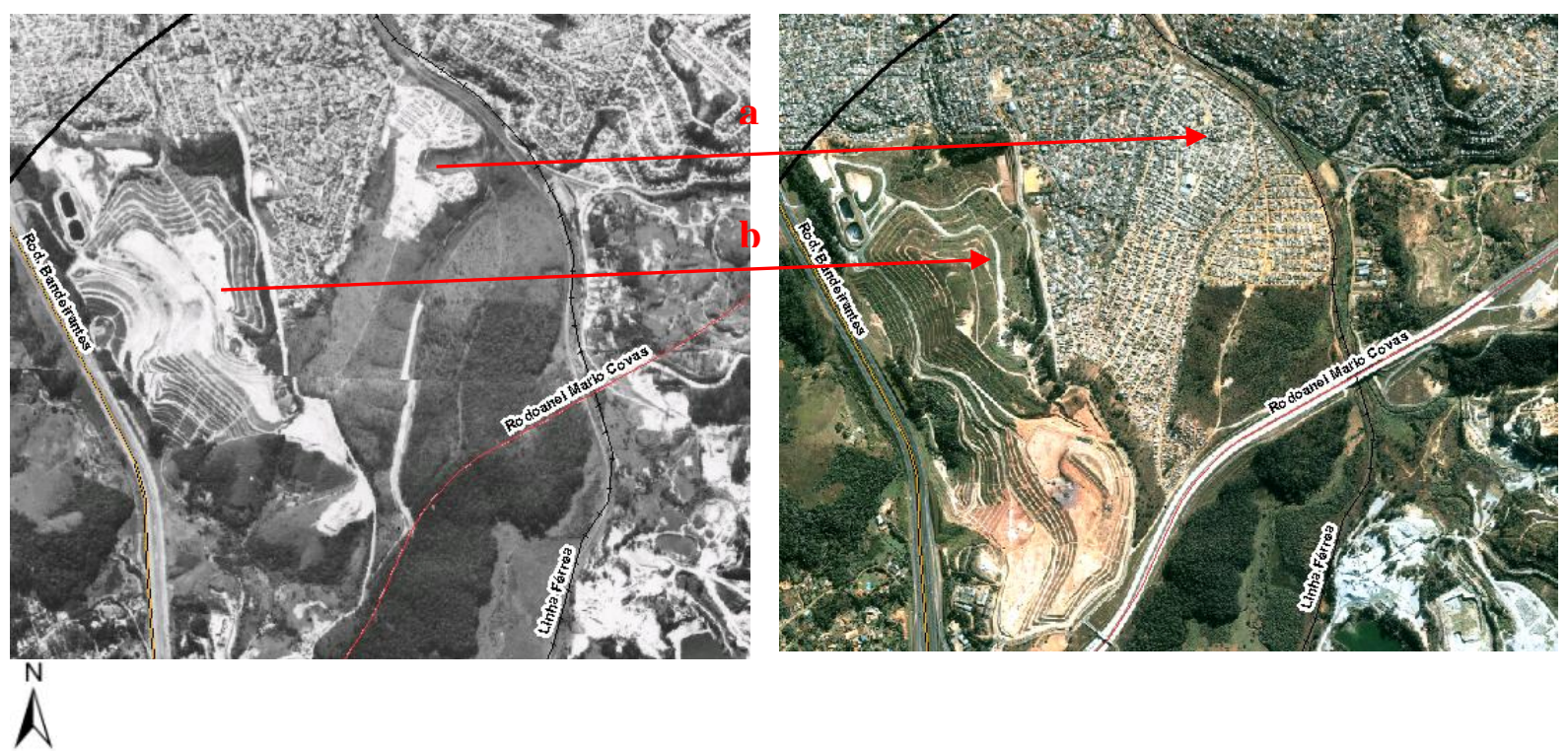

Figura 26 (a): Área de solo exposto ocupada por residências

Figura 26 (b): Área de solo exposto ocupada por vegetação em processo de readequação Organizado pela autora

Fonte: LASERE (1994) e FUNCATE (2002) 
A área construída ocupava cerca de 13,97\% da área no ano de 1994, aumentando para 19,97\% em 2002 (Gráfico VII).

Gráfico VII: Quantidade em $\mathrm{m}^{2}$ de área construída na área de estudo

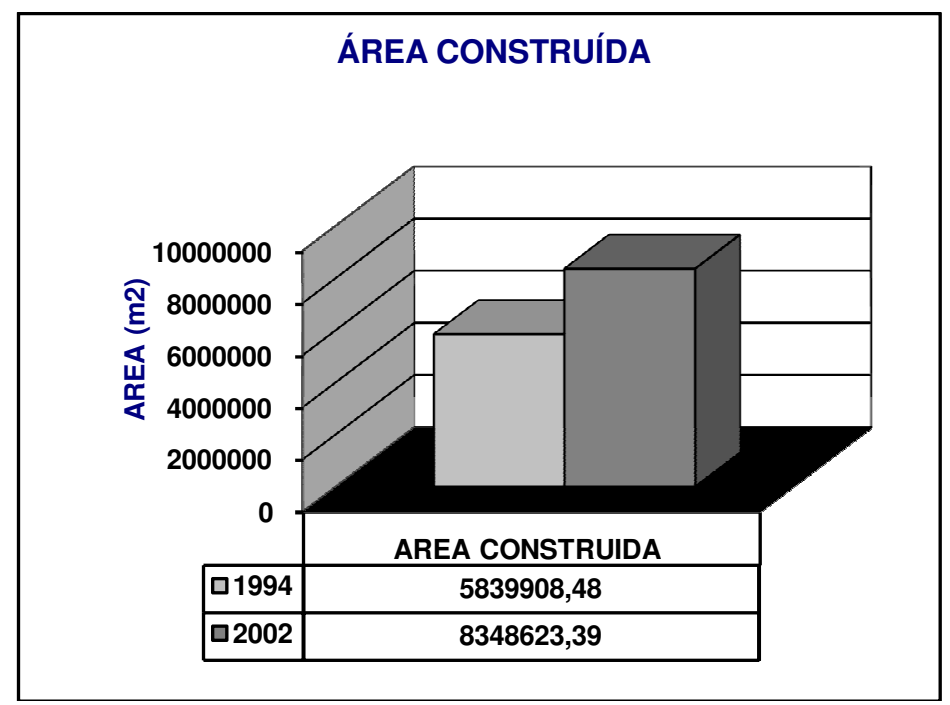

Elaboração e organização da autora

Pode-se citar como exemplo, a Vila Nova no bairro de Perus. Há uma ocupação residencial e uma área de gramínea próximas a linha férrea no ano de 1994 (figura 27). A Vila Nova se expandiu sobre a área de gramínea e em direção ao Rodoanel, formando o Recanto dos Humildes.

Segundo entrevistas com moradores e análise das imagens aéreas, após a construção do Rodoanel, esta vila teve uma segunda fase de expansão, em suas margens, formando uma favela (Recanto da Paz), com acessos para pedestres a rodovia. (Figura 28). 

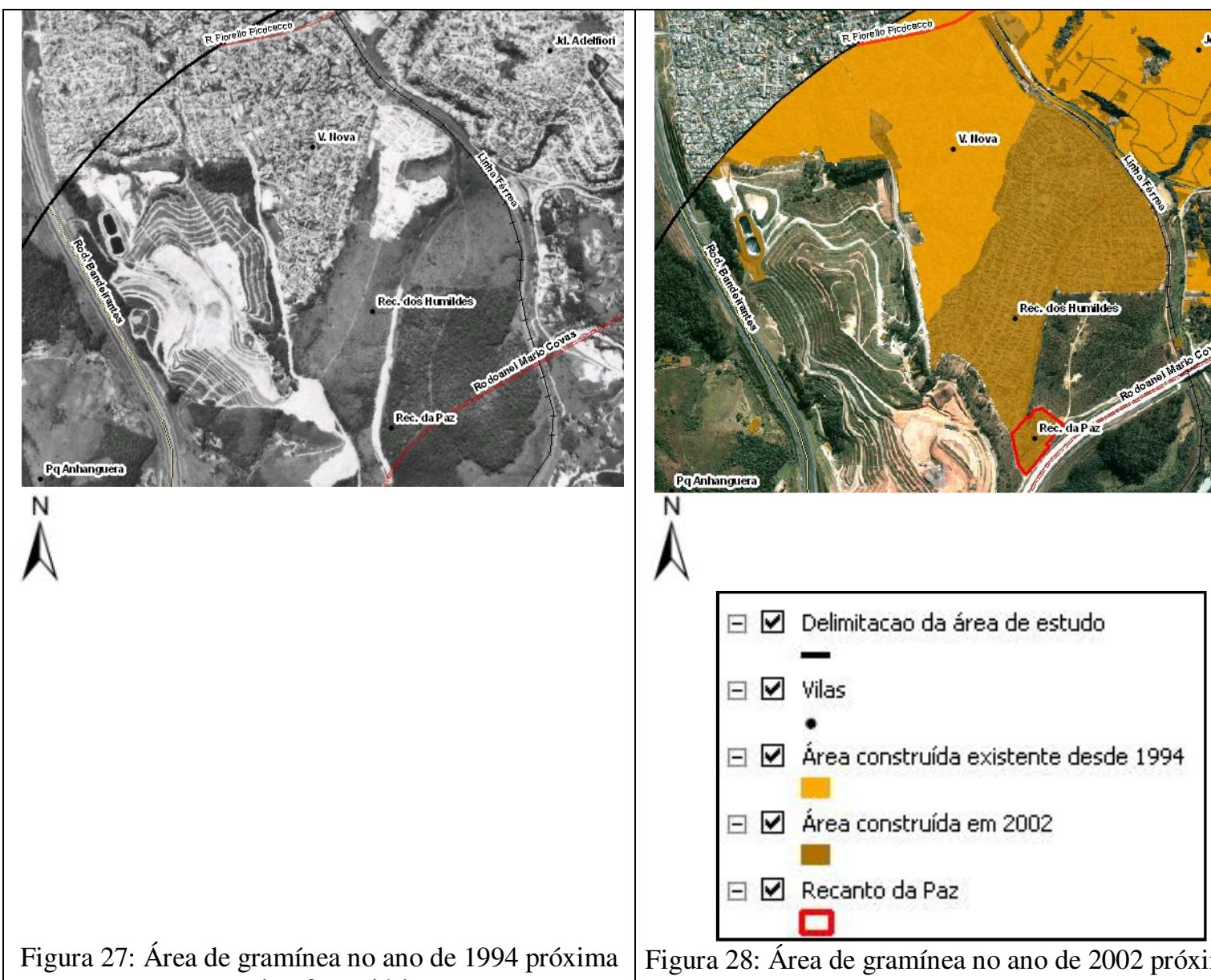
ao eixo ferroviário

Figura 28: Área de gramínea no ano de 2002 próxima ao eixo ferroviário e ao Rodoanel

Elaborado e organizado pela autora

Fonte: LASERE (1994) e FUNCATE (2002)

Entende-se por galpões aquelas construções identificadas primeiramente na interpretação da imagem aérea, podendo ser indústrias, depósitos ou prédios institucionais com características de galpões (forma, tamanho do prédio e tonalidade do telhado).

No ano de 1994, a área total de galpões totalizava 1,07\% da área de estudo e, no ano de 2002 este número aumentou para 1,40\% (Gráfico VIII). 
Gráfico VIII: Quantidade em $\mathrm{m}^{2}$ de área construída na área de estudo

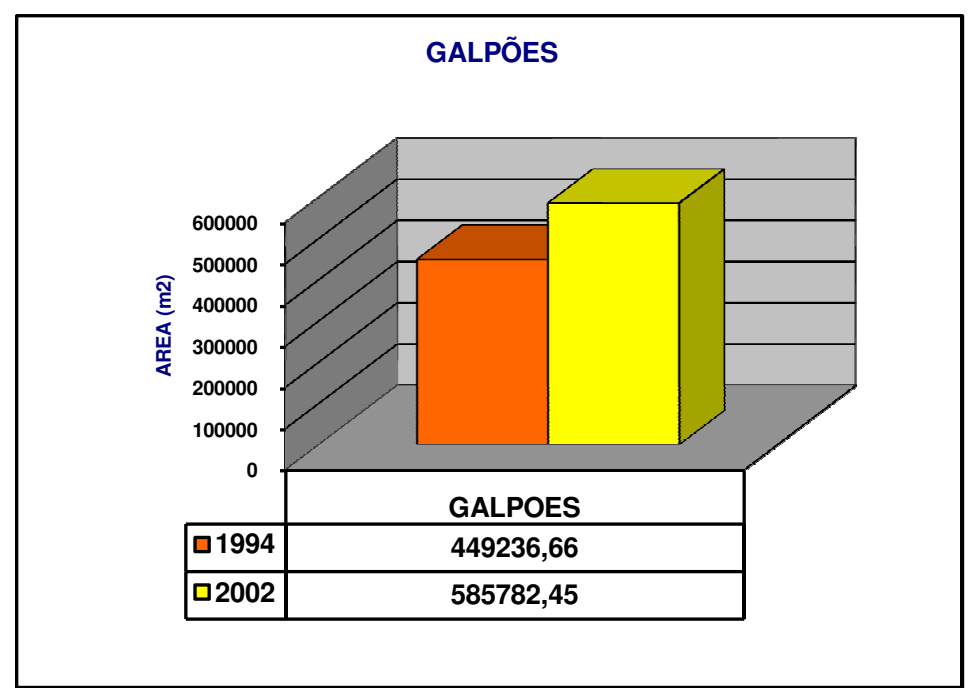

Elaborado e organizado pela autora

Este aumento ocorreu não somente pelo crescimento das unidades industriais e escolas nas vilas, como também a ampliação das áreas das unidades já construídas que passaram por reformas (Figura 29).

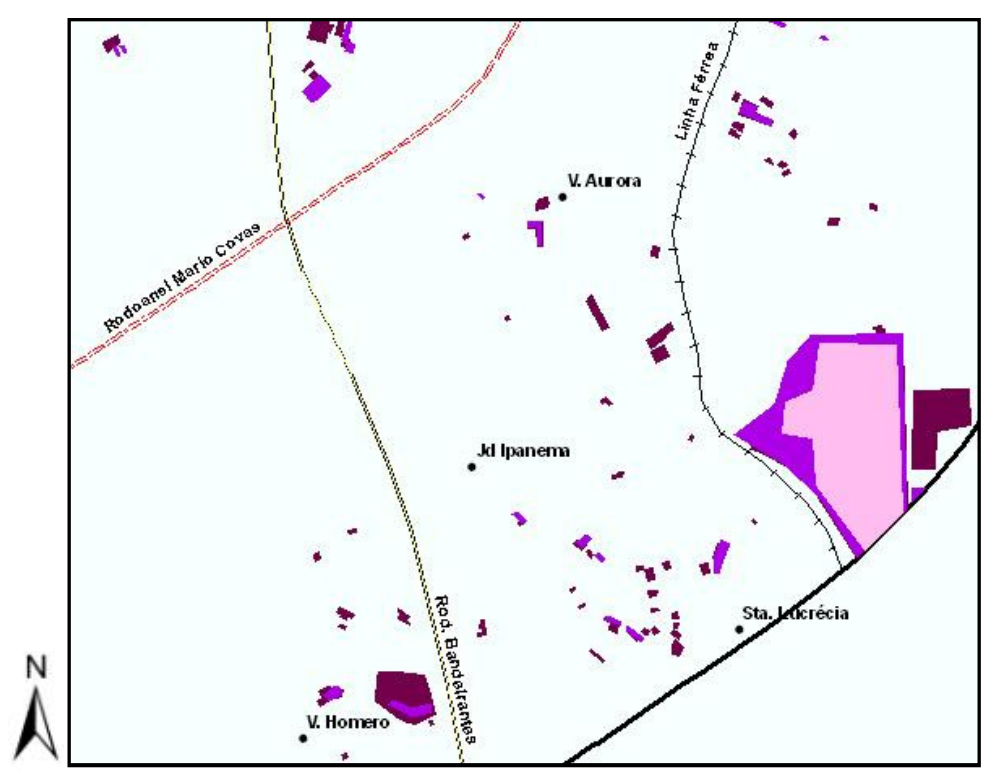




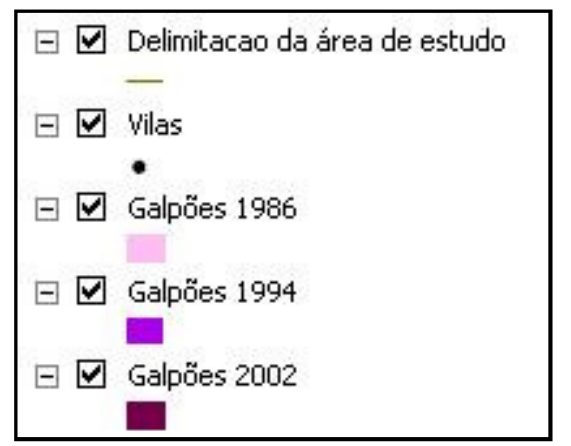

Figura 29: Localização e situação dos galpões nos anos de 1984, 1994 e 2002

Elaborado e organizado pela autora

Fonte: LASERE (1994) e FUNCATE (2002); IBGE (BRASIL,1984)

O SIG foi utilizado para a análise do uso e ocupação do solo no entorno do Rodoanel Mario Covas, mostrando-se capaz de auxiliar levantamentos quantitativos que são muito importantes no estudo da ocupação do solo. Por meio do SIG é possível a organização e o gerenciamento de informações por meio de banco de dados que possui o diferencial de trabalhar com os dados georeferenciados. O SIG também possibilita a visualização das informações de maneira organizada e de fácil compreensão.

O SIG permitiu a comparação dos resultados da classificação analógica e classificação automática, indicando qual a melhor forma de se utilizar estas técnicas em uma imagem de alta resolução, neste caso, a IKONOS, para se obter resultados mais próximos da realidade.

Analisando-se os resultados das duas classificações (analógica e automática), pode-se dizer que a classificação automática atende bem aos objetivos do presente trabalho, sendo a mais adequada a classificação automática por regiões supervisionada (Battacharya com limiar de aceitação de $\mathbf{7 5 \%}$ ) das opções testadas na imagem de alta resolução IKONOS. Isso não quer dizer que este método não ofereceu erros, mas na comparação com os outros testes, este foi o que se mostrou mais próximo da interpretação visual da imagem e da realidade dos trabalhos de campo.

\subsection{Análise comparativa das técnicas de classificação do uso e ocupação do solo}

A classificação automática supervisionada foi feita na imagem IKONOS. A área verde densa apresentou forte diminuição na classificação automática em relação a analógica no ano de 2002. Isto ocorre porque o método analógico agrupa as áreas verdes com suas sombras na maior parte das vezes, pois não é possível o olho do observador detectar todos os pequenos detalhes, considerar regiões muitas vezes imperceptíveis a olho nu na imagem. Já o método 
automático detecta tais regiões com mais facilidade, distinguindo áreas que parecem ser iguais na interpretação visual.

Em trabalho de campo e na interpretação visual foi visto que, algumas áreas onde havia vegetação rasteira (classe gramínea e árvores esparsas) foi coberta por mato alto e árvores. Então, esta informação contradiz o que os dados mostram, se compararmos a classificação analógica de 1994 com a classificação automática do ano de 2002, onde a área verde densa diminui. Seria inclusive, mais plausível, que estas áreas verdes realmente diminuíssem devido à expansão de áreas residenciais. Portanto, esta informação pode iludir, quando fazemos a seguinte análise:

A classificação analógica das fotografias aéreas, como da imagem IKONOS, também oferece erros, principalmente por possuir resolução espacial e espectral ainda mais baixa. As áreas de sombras ou áreas mais escuras a olho nu são vistas, muitas vezes, de maneira unida na interpretação visual enquanto que, na classificação automática elas são em grande parte separadas por pequenos detalhes heterogêneos. Sendo assim, caso a área verde densa fosse classificada em uma imagem de alta resolução do ano de 1994 automaticamente, esta poderia mostrar também considerável diminuição, como ocorreu com a imagem IKONOS (Gráfico IX)

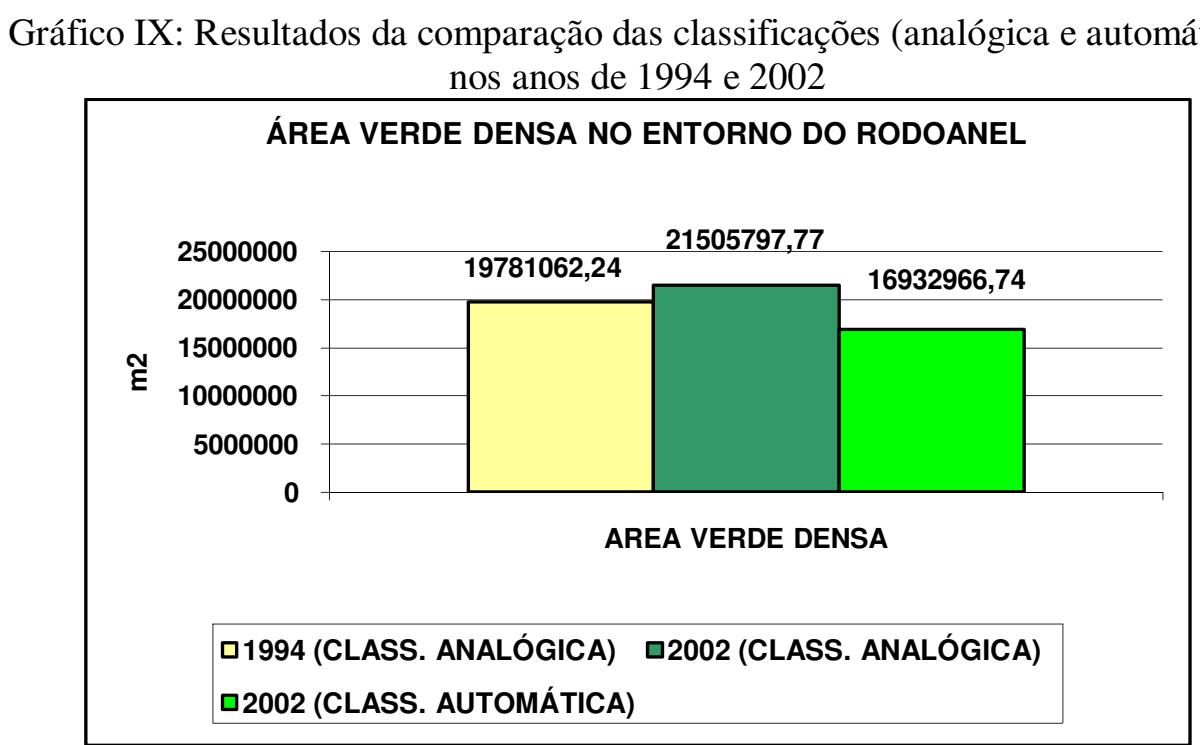

Elaborado e organizado pela autora

As classificações (analógica e automática) das áreas de gramínea e árvores esparsas apresentaram resultados mais próximos entre si na análise da imagem de 2002. Isto ocorreu 
porque são áreas mais fáceis do observador interpretar visualmente, pois não possuem tonalidades que provoquem muita confusão como no caso das áreas verdes densas (Gráfico $\mathrm{X})$.

Gráfico X: Resultados da comparação das classificações (analógica e automática) nos anos de 1994 e 2002

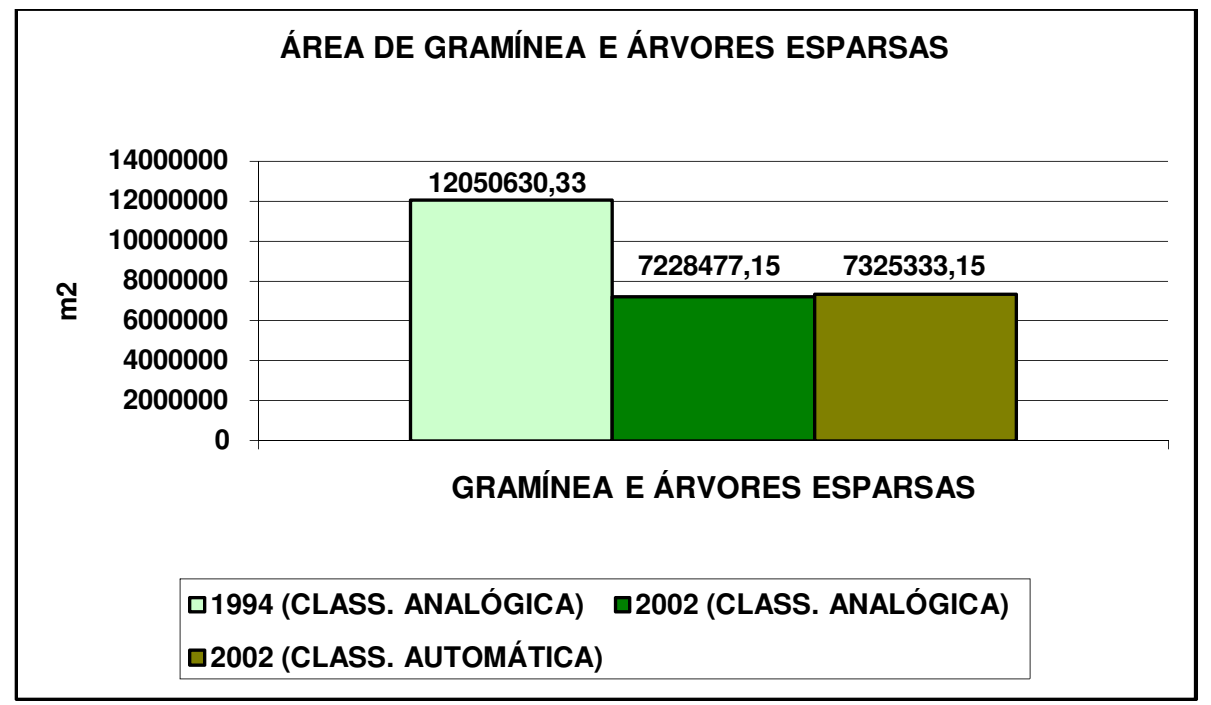

Elaborado e organizado pela autora

A área de solo exposto apresentou uma diferença maior nos resultados das duas classificações na imagem de 2002. Isto ocorreu devido ao reconhecimento pela classificação automática de pequenas áreas como terrenos e ruas não asfaltadas nas vilas. Na classificação analógica, muitas vezes, não é possível a separação de pequenas regiões das demais como, por exemplo, pequenas ruas atravessando conjunto denso de casas.

Do ano de 1994 para o ano de 2002, a área de solo exposto diminuiu nos resultados da classificação analógica. Já em relação a classificação automática esta área aumentou. Isso ocorreu porque, como foi dito acima, o método analógico realizado nas fotografias aéreas de 1994 não consideram ruas e pequenas áreas de solo exposto. Normalmente, neste método, estas pequenas áreas confundem-se com a classe "área construída". Se as fotografias aéreas de 1994 tivessem alta resolução, pelo processo de classificação automática, estas pequenas áreas de solo exposto teriam mais chances de ser consideradas devido a maior precisão deste método. Provavelmente o resultado final para classificação automática de 1994 seria um número mais alto. Assim, na classificação automática, a área de solo exposto seria maior em 1994 e poderia ser menor no ano de 2002, tendo diferença semelhante a apresentada na classificação analógica de 1994 e 2002. (Gráfico XI). 
Gráfico XI: Resultados da comparação das classificações (analógica e automática) nos anos de 1994 e 2002

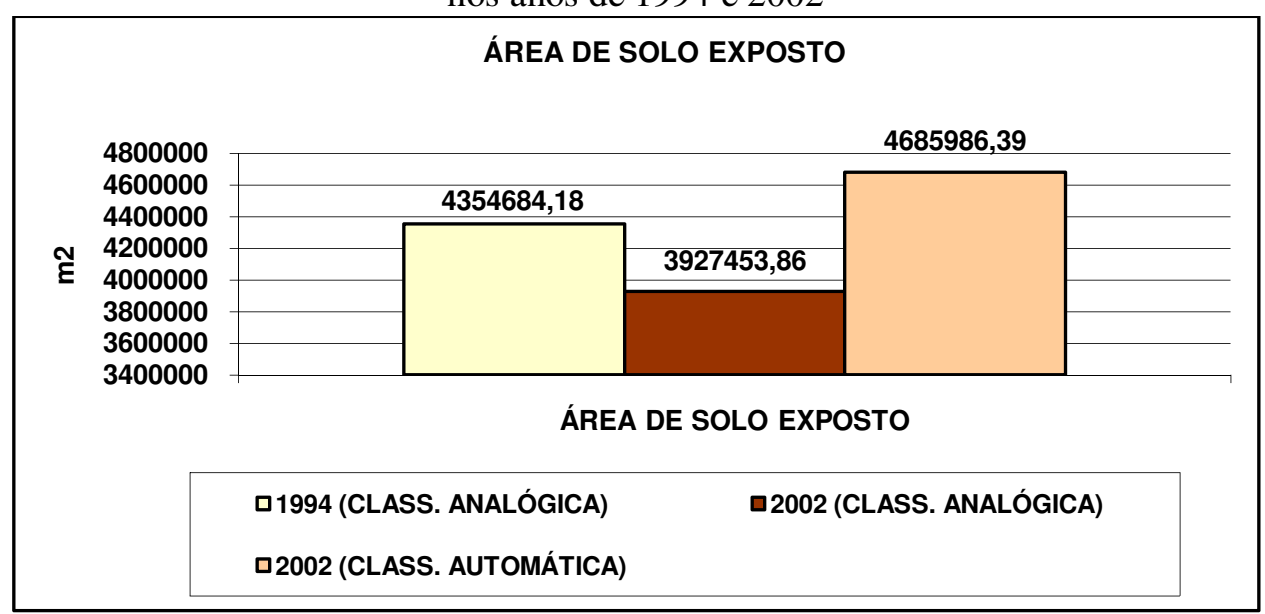

Elaborado e organizado pela autora

A classificação analógica da "área construída" na imagem de 2002 apresentou um resultado maior que a classificação automática, pois no método analógico, a interpretação visual considera pequenas regiões de solo exposto parte das vilas por apresentarem confusão, principalmente com telhados de tonalidade clara. Se estas áreas ficam inseridas junto às áreas construídas, logo esta área aumenta. Já na classificação automática, pequenas regiões de solo exposto são consideradas outra classe, diminuindo assim, a área construída. Caso as imagens de 1994 fossem de alta resolução, permitindo a classificação automática, a área poderia também diminuir, por subtrair desta, as áreas referentes a classe solo exposto (Gráfico XII).

Gráfico XII: Resultados da comparação das classificações (analógica e automática) nos anos de 1994 e 2002

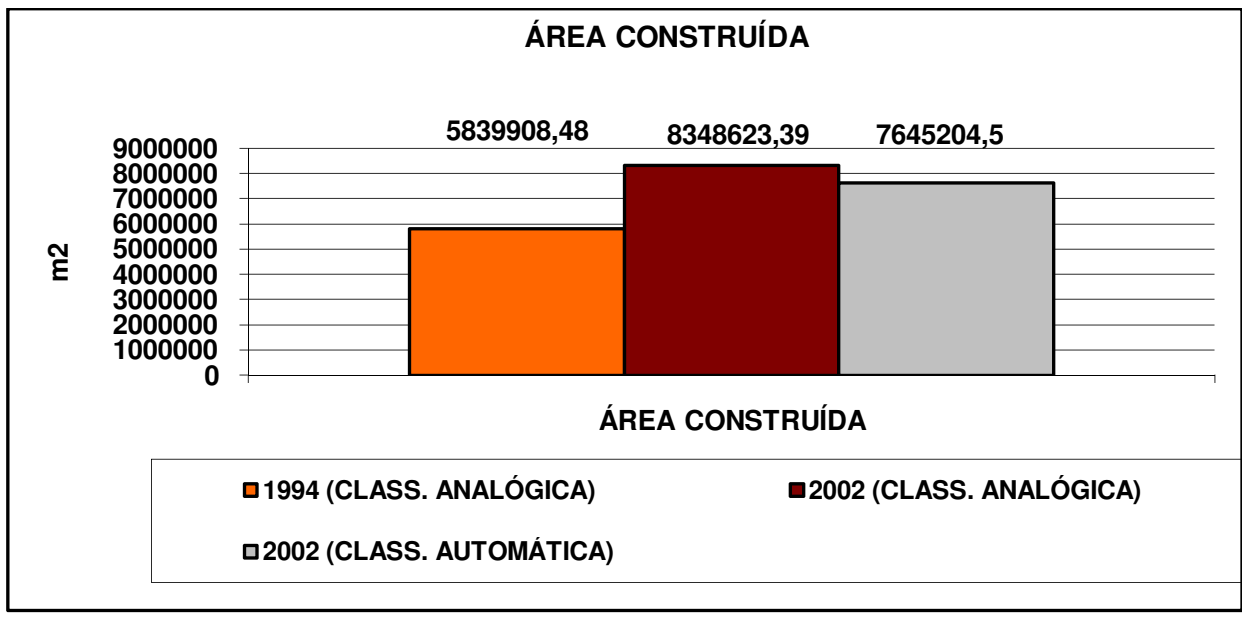

Elaborado e organizado pela autora 


\subsection{Caracterização e análise temporal por meio de imagens aéreas e trabalhos de campo} (1994 - 2009)

Em trabalhos de campo foi possível observar que existem mais áreas de proteção ambiental na área de estudo do que no restante do trecho oeste do Rodoanel Mario Covas.

As Zonas de Proteção Ambiental estão concentradas no município de São Paulo, ocupando, no município, mais de $50 \%$ do território englobado pelos 5 $\mathrm{km}$ em estudo (Parque do Jaraguá, Parque Anhanguera Perus, Parque das Nascentes do Carapicuíba, Parque Ipê, entre outros), e no município de Embu. Em Osasco essas áreas estão restritas às margens de corpos d'água e em Barueri, nas proximidades da lagoa de Carapicuíba. (FAUUSP, 2005, p.89)

Em trabalhos de campo, do ano de 2006 ao ano de 2009 observou-se a construção informal de marginais (foto 4) e acessos para pedestres (fotos 5, 6 e 7), mesmo com cercas que separam a rodovia das ocupações. No caso de acesso para carros, a maioria estão interditados (fotos 8 e 9).

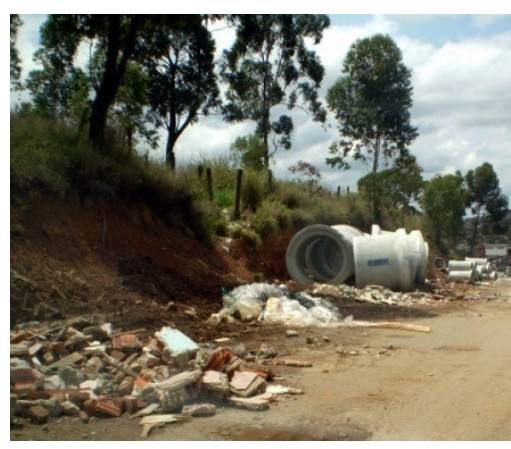

Foto 4: Marginal do Rodoanel

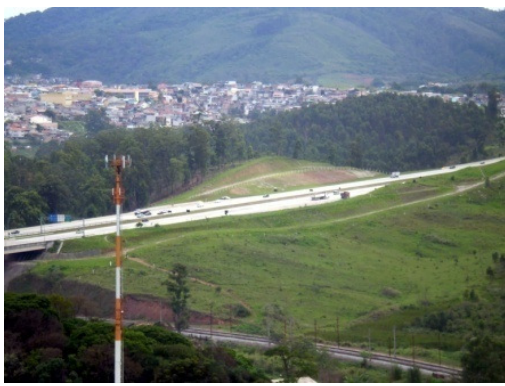

Foto 7: Via de acesso - Rodoanel e linha férrea

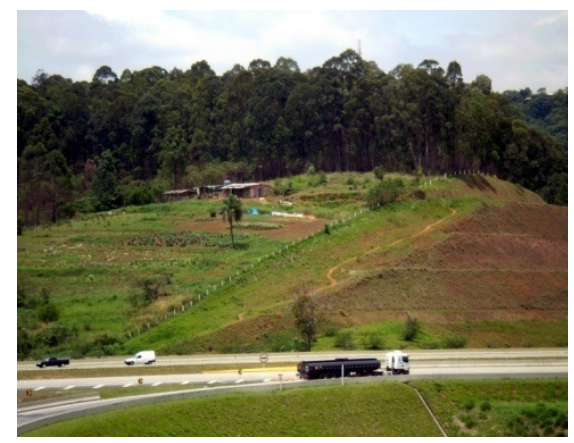

Foto 5: Via de acesso informal para pedestres

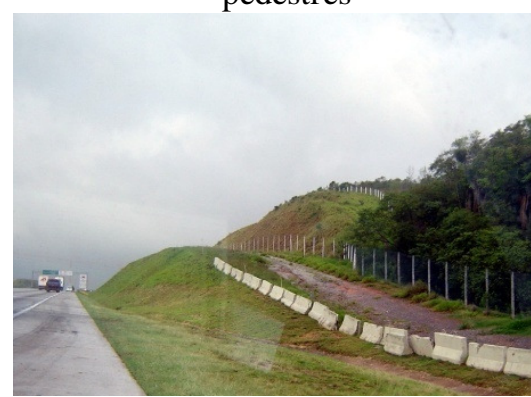

Foto 8: Acesso para carros interditado Fotos da autora

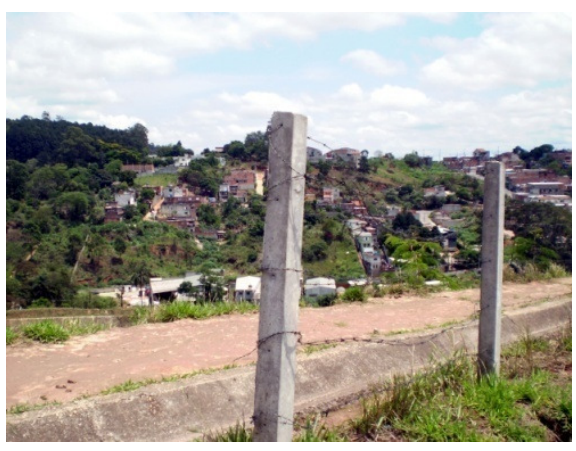

Foto 6: Via de acesso informal para pedestres



Foto 9: Acesso para carros interditado 


\subsubsection{Perus}

O Recanto da Paz (ou Recanto Paraíso) e Recanto dos Humildes são ocupações mais recentes e carentes no bairro de Perus. Segundo entrevistas com moradores, estas vilas possuem infra-estrutura muito deficiente ou não possuem, as construções são de baixa qualidade e são poucos os transportes públicos que atendem a demanda para o centro urbano da cidade de São Paulo. O Recanto dos Humildes surgiu da expansão da Vila Nova, e logo depois o Recanto da Paz se expandiu em direção ao Rodoanel após sua construção.

Com a implantação do Rodoanel, aumentaram as ligações com a rodovia de maneira informal como passagens para pedestres trilhadas pelos próprios moradores como forma de acesso para bairros e empresas próximas. As passagens para automóveis foram abertas, mas atualmente encontram-se interditadas, o que mostra uma resistência a este tipo de acesso informal para as vilas; o mesmo não ocorre com passagens para pedestres. Mesmo o acesso até as passarelas construídas para que as pessoas não utilizem o Rodoanel a pé, são precários, afirmam alguns moradores. Há necessidade de mais transportes públicos para áreas centrais da cidade ou mesmo para bairros próximos, bem como a necessidade de mais empregos na região e infra-estrutura para as vilas. A população destas vilas permanece isolada fisicamente, como já retratava o relatório elaborado pela FAUUSP em 2005.

De modo geral, foi levantado nesta pesquisa que a maior parte dos assentamentos humanos existentes no entorno imediato do Rodoanel já existiam antes da sua construção e estavam vinculados ao sistema viário local, às ferrovias e rodovias pré-existentes (FAUUSP, 2005, p. 62).

Segundo documento elaborado pela Dersa (SÃO PAULO, 2005a, p. 11), com relação ao Recanto da Paz, "cabe notar que a expansão da favela se deu junto ao Aterro Sanitário Bandeirantes, que proporciona sustento às famílias de "catadores' que trabalham no local."

Segundo moradores, há possibilidade de remoção das famílias do Recanto da Paz, mas a relocação e indenizações ainda é assunto discutido, por isso a ocupação continua no limite da faixa de domínio da DERSA.

Neste contexto, levanta-se a hipótese de que a possibilidade de indenização ou de reassentamento habitacional para os moradores da área tenha impulsionado a expansão e o adensamento do núcleo nos últimos anos, principalmente em áreas próximas ao Rodoanel, evidentemente além do aumento da acessibilidade a locais de emprego próximos (FAUUSP, 2005, p.65) 
Em análise a imagens aéreas de 1994 percebe-se que não há ocupação onde atualmente encontra-se o Recanto dos Humildes e Recanto da Paz. A ocupação residencial mais próxima é a Vila Nova, já consolidada e com infra-estrutura no início da década de 1990, segundo moradores do local e análise da fotografia aérea de 1994 (Figura 30). A Vila Nova ainda estava em expansão e tinha como principal meio de transporte a estação de trens de Perus. No início da década de 1990, a mancha urbana da vila se expandia e a população contava com ruas asfaltadas, escola, praça e pequenos comércios. Uma reclamação dos moradores muito comum na época era o mau cheiro vindo do aterro sanitário, muito próximo à vila, problema este que seguiu por muitos anos e que ainda hoje incomoda, mesmo em menor escala, devido ao uso de tecnologias mais modernas no tratamento do lixo. É possível notar nitidamente que o crescimento da mancha urbana da Vila Nova fez com que surgisse o Recanto dos Humildes (Figura 31). Atualmente, a vila continua sem infra-estrutura suficiente e o crescimento da mancha urbana do Recanto dos Humildes (Foto 10) fez com que surgisse uma nova ocupação próxima ao Rodoanel, o Recanto da Paz (Foto 11).

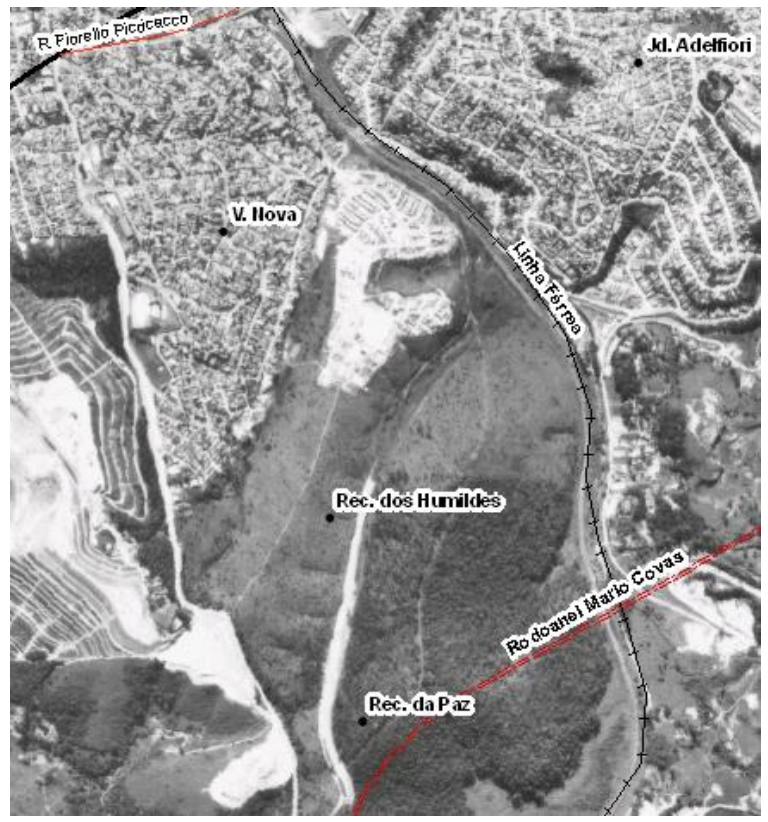

Figura 30: Vila Nova, Recantos dos Humildes e Recanto da Paz em 1994

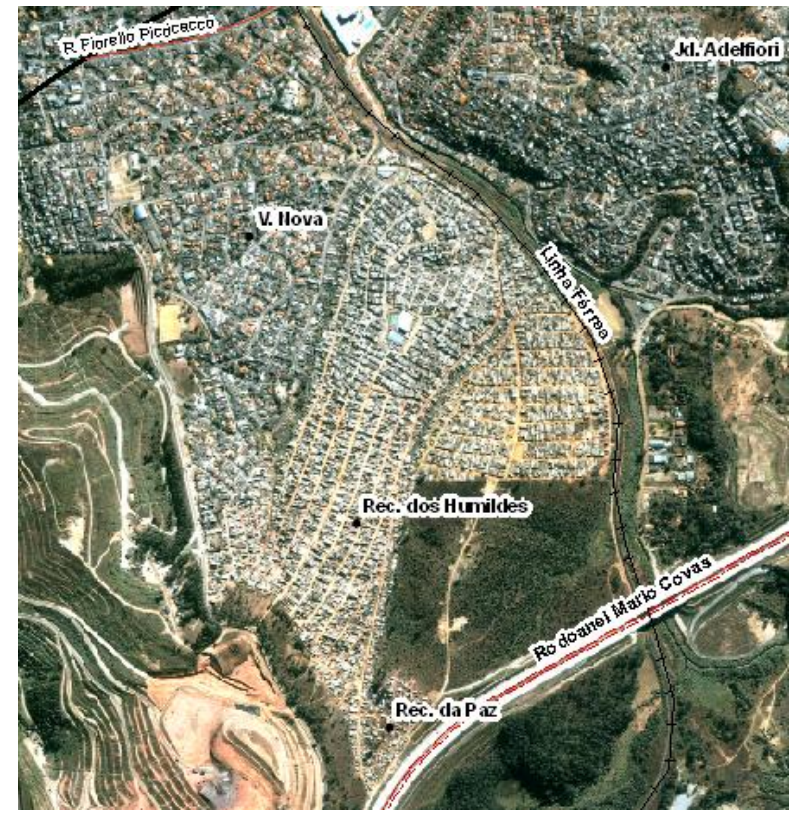

Figura 31: Vila Nova, Recantos dos Humildes e Recanto da Paz em 2002

Organizado pela autora

Fonte: LASERE (1994) e FUNCATE (2002) 
Segundo relatório elaborado pela FAUUSP (2005, p.65), "Verifica-se primeiramente que no ano de 1998 o núcleo já se apresentava como consolidado e vinculado à mancha urbana da RMSP, se expandindo prioritariamente ao longo da Linha A da CPTM, em área próxima à estação Perus."

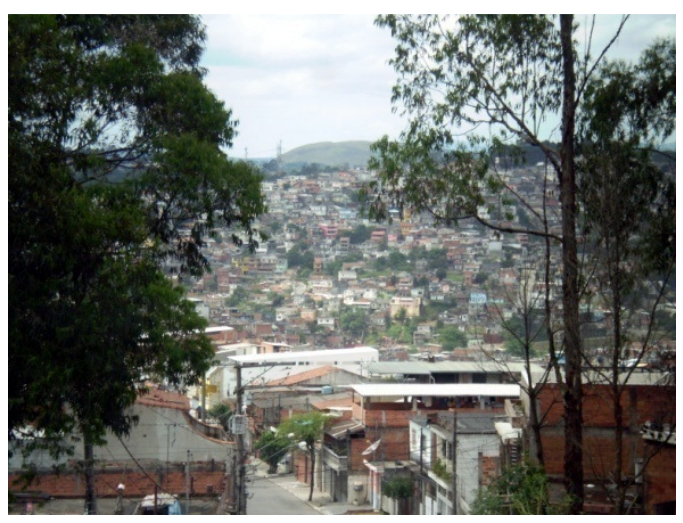

Foto 10: Recanto dos Humildes



Foto 11: Recanto da Paz

Fotos da autora

Na Vila Sulina (Foto 12), a ocupação residencial precária pertencente ao bairro de Perus já existia no início da década de 1990, de acordo com moradores do bairro de Perus e análise da imagem aérea de 1994 (Figura 32). Em comparação com as imagens aéreas de 1994 e 2002, observa-se que a Vila Sulina se expandiu principalmente em direção à rodovia Anhanguera (Figura 33).

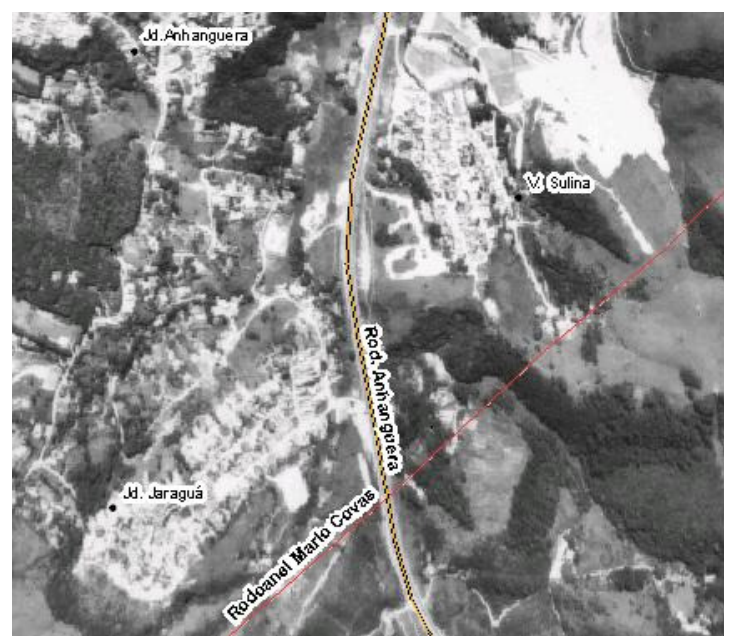

Figura 32: Jardim Anhanguera, Jardim Jaraguá e Vila Sulina em 1994

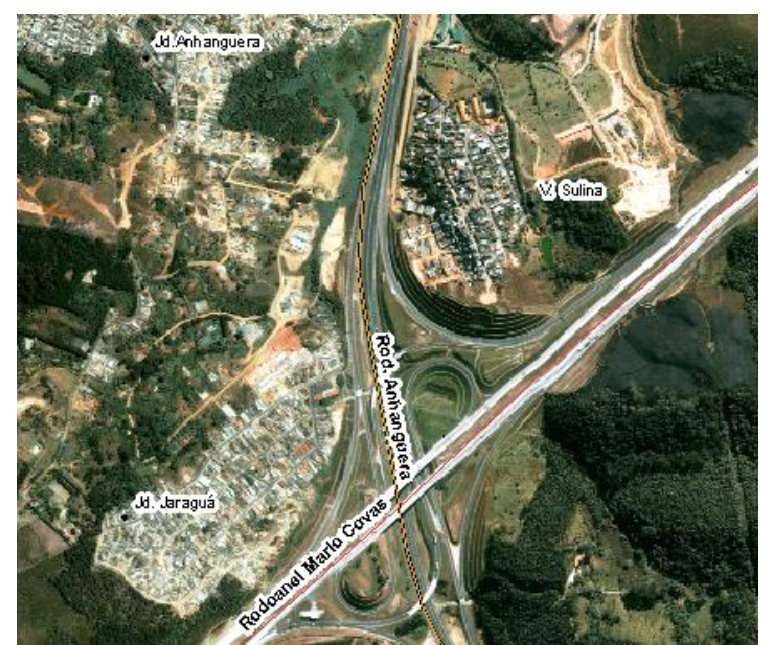

Figura 33: Jardim Anhanguera, Jardim Jaraguá e Vila Sulina em 2002

Organizado pela autora

Fonte: LASERE (1994) e FUNCATE (2002) 
Na direção do Rodoanel foi realizada uma estabilização de talude e desmatamento de uma área para a construção da rodovia e das alças de acesso. Grande parte da área ocupada é de construções de baixa qualidade e carente de infra-estrutura como asfalto e iluminação pública, mas já existem construções de alvenaria, com acabamento, mostrando algumas melhorias na qualidade de vida da vila. As vias de acesso formais também ocorrem em direção à rodovia Anhanguera e acessos informais para pedestres ocorrem tanto na direção da rodovia Anhanguera, como do Rodoanel, mesmo com as cercas separando a rodovia da vila (Foto 13).

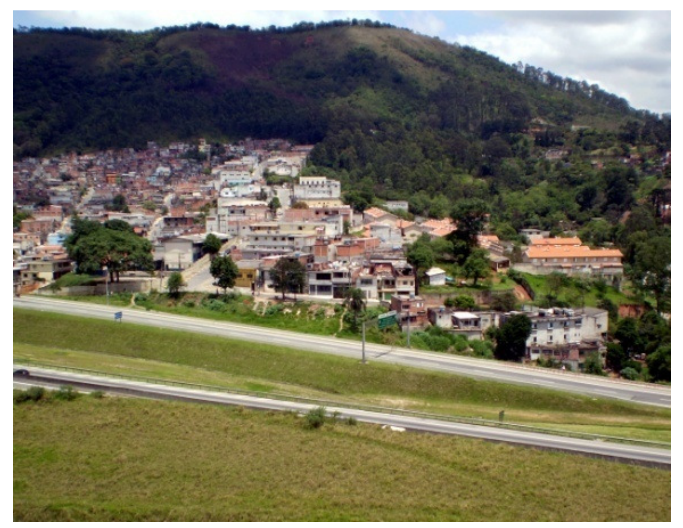

Foto 12: Vila sulina

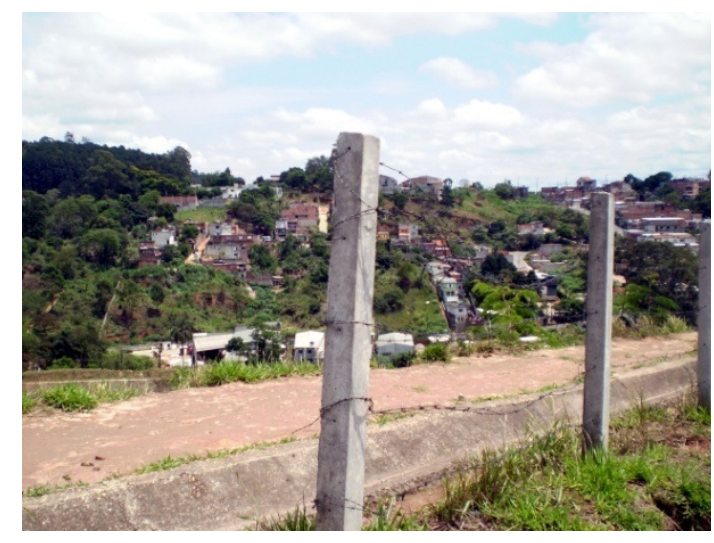

Foto 13: Vila sulina e passagem informal para pedestres

Fotos da autora

A Vila Hungaresa é uma ocupação que teve início entre 1920 e 1930 devido ao surgimento de vilas operárias no entorno da fábrica de cimento Portland Perus. Embora a Vila Hungaresa esteja fora do perímetro da fábrica, ainda era considerada vila operária por iniciativa dos trabalhadores do setor de sacaria, segundo Siqueira (2001, p.34). A vila se expandiu mesmo após o fechamento da fábrica de cimento, principalmente pela sua localização favorável.

Em 1994 ainda não havia os conjuntos populacionais e uma escola pública que atualmente existe (Figuras 34 e 35; Foto 14). 


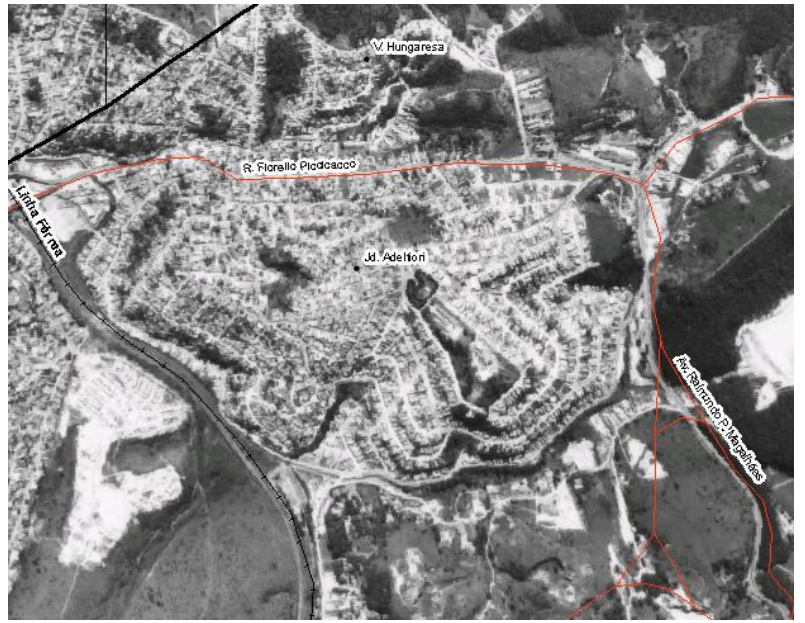

Figura 34: Jardim Adelfiori e Vila Hungaresa em 1994 Figura 35: Jardim Adelfiori e Vila Hungaresa em 1994 Organizado pela autora Fonte: LASERE (1994) e FUNCATE (2002)

A vila vem passando por melhorias como infra-estrutura e construções de instituições públicas.



Foto 14: Vila Hungaresa no bairro de Perus (2009) Foto da autora

O Jardim. Britânia era uma vila consolidada no ano de 1994 de acordo com imagens aéreas da época (Figura 36). A vila segue até as margens da rodovia Anhanguera com vias de acessos formais. As indústrias instaladas nas proximidades da rodovia Anhanguera impulsionaram o crescimento do Jardim Britânia (Foto 15), assim como a Vila Jaraguá (Figura 37). 


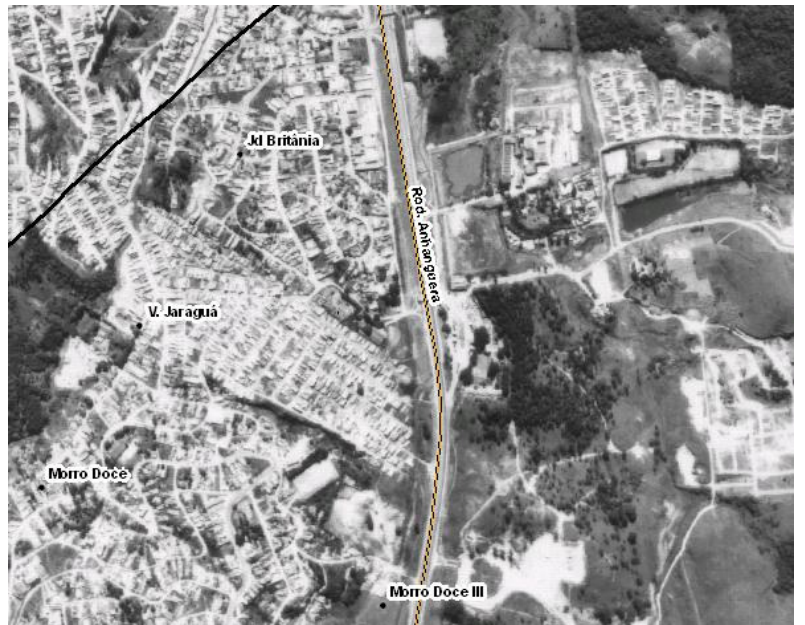

Figura 36: Jardim Britânia, Vila Jaraguá e Morro Doce em 1994

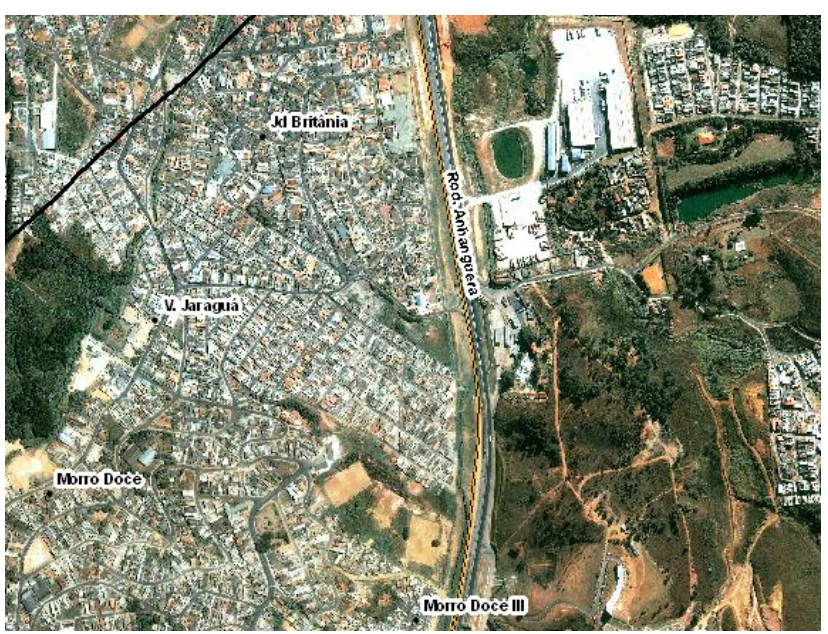

Figura 37: Jardim Britânia, Vila Jaraguá e Morro Doce em 2002

Organizado pela autora

Fonte: LASERE (1994) e FUNCATE (2002)

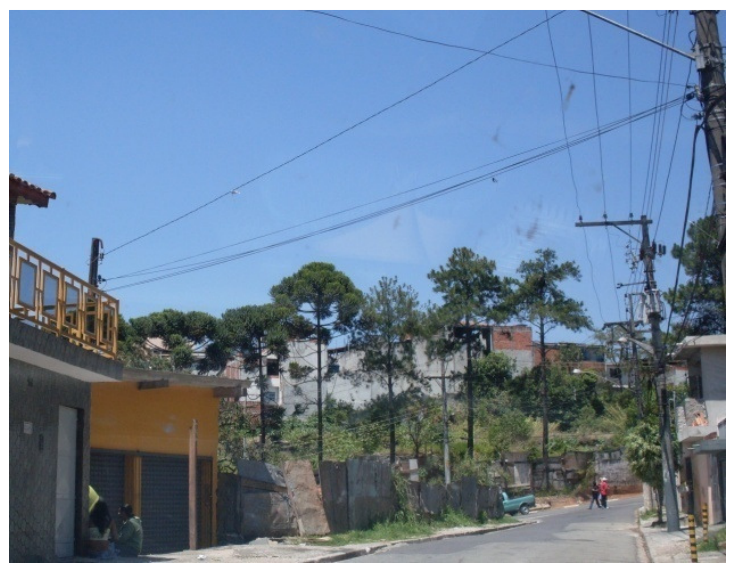

Foto 15: Jardim Britânia

Foto da autora

O Morro Doce é uma ocupação proveniente de um crescimento destas vilas, sendo também pertencente a subprefeitura de Perus e dividido em Morro Doce I, II e III. A proximidade destas ocupações causam confusão mesmo entre os moradores. O Jardim Parque Anhanguera é uma ocupação mais antiga proveniente da construção da rodovia Anhanguera e as empresas que ali se instalaram. A Vila Morro Doce é mais recente e se diferencia pelas casas com materiais de baixa qualidade e carência de infra-estrutura.

O Jardim Parque Anhanguera apresenta-se como uma vila também carente, mas por ser uma vila consolidada há décadas, possui melhor infra-estrutura como asfalto e iluminação pública; e casas de alvenaria e reformadas (Figuras 38 e 39). 
A Favela Jardim Jaraguá é outra ocupação muito próxima à rodovia Anhanguera existente antes da construção do Rodoanel, que sofreu desapropriação para a construção de uma das alças de acesso entre o Rodoanel e a rodovia Anhanguera, segundo moradores. Tratase de uma vila sem infra-estrutura, com construções de baixa qualidade, que cresceu sem planejamento adequado. Em 1994, o local já era ocupado com as mesmas características atuais, porém, havia menos construções. Comparando as imagens aéreas de 1994 e 2002, percebe-se uma expansão da mancha urbana, principalmente nas proximidades do Rodoanel, nos limites da faixa de domínio da DERSA (Figuras 40 e 41). São barracos estão encostados no Rodoanel e nas alças da rodovia Anhanguera. Os acessos formais localizam-se na rodovia Anhanguera, já no Rodoanel existem apenas acessos informais para pedestres em forma de trilhas. Estes acessos não estão diretamente ligados ao Rodoanel, embora não haja dificuldades em alcançar a rodovia. Normalmente, os acessos estão ligados às alças que interligam o Rodoanel a rodovia Anhanguera.

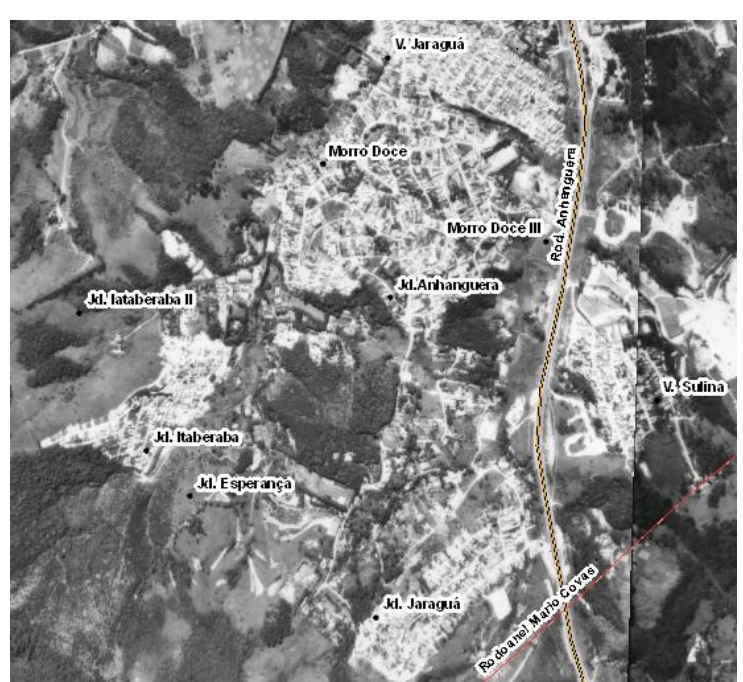

Figura 38: Vila Jaraguá, Morro Doce, Morro Doce III, Jardim Anhanguera, Jardim Itaberaba, Jardim Itaberaba II, Jardim Esperança, Jardim Jaraguá e Vila Sulina em 1994

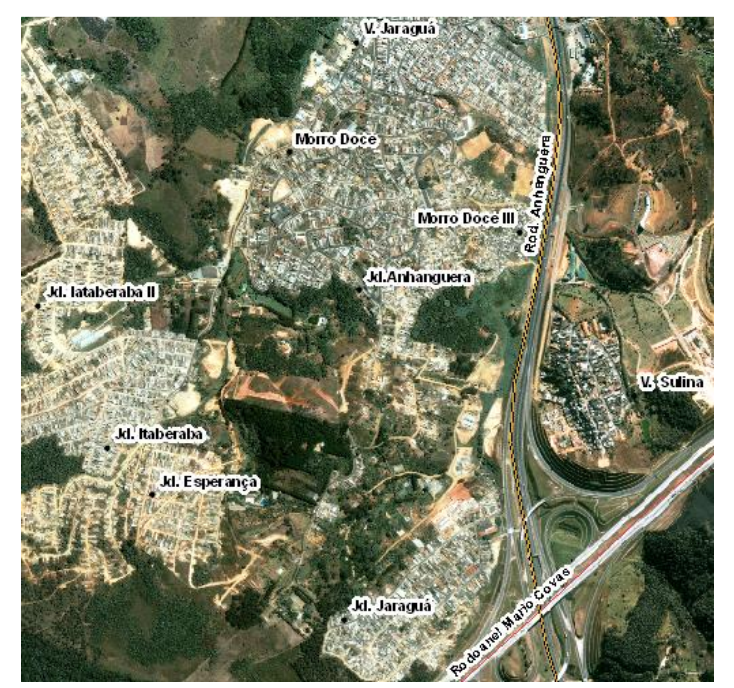

Figura 39: Vila Jaraguá, Morro Doce, Morro Doce III, Jardim Anhanguera, Jardim Itaberaba, Jardim Itaberaba II, Jardim Esperança, Jardim Jaraguá e Vila Sulina em 2002

Organizado pela autora

Fonte: LASERE (1994) e FUNCATE (2002)

Os moradores dizem que não há transportes públicos suficientes para áreas centrais da cidade de São Paulo e na vila não há empregos, apenas pequenos comércios, o que não é suficiente para atender a demanda de trabalhadores. Os moradores observam que o Rodoanel é útil para pessoas que possuem carro, e que na vila muitos deles dependem de transportes 
públicos e não de condução própria. Na imagem aérea de 1994 observa-se ruas de terra, o que indica a falta de infra-estrutura no local. Atualmente, a situação não é muito diferente, mas existem muitas ruas já asfaltadas e casas de alvenaria (Fotos 16 e 17). A ocupação continua a se expandir sem infra-estrutura adequada para a população.


Fotos 16 e 17: Favela Jardim Jaraguá

Fotos da autora

A Vila Sol Nascente mostrava indícios de ocupação em 1994, próximo de onde atualmente passa o Rodoanel (Figura 40). O acesso que hoje passa por cima do Rodoanel já existia, mas antes era uma rua de terra que cortava uma área com vegetação rasteira e árvores. Mais ao norte desta escassa ocupação em 1994, observa-se na imagem aérea de 1994, traçados de ruas de terra indicando um novo loteamento em forma de "V", unido a outra ocupação próxima a rodovia Anhanguera e às indústrias ali presentes na área. Desde a década de 1990 estas vilas vêm se expandindo e tornando-se mais densas, visto o surgimento de uma nova "gleba"(assim denominada pelos moradores) chamada Morada do Sol (Figura 41).
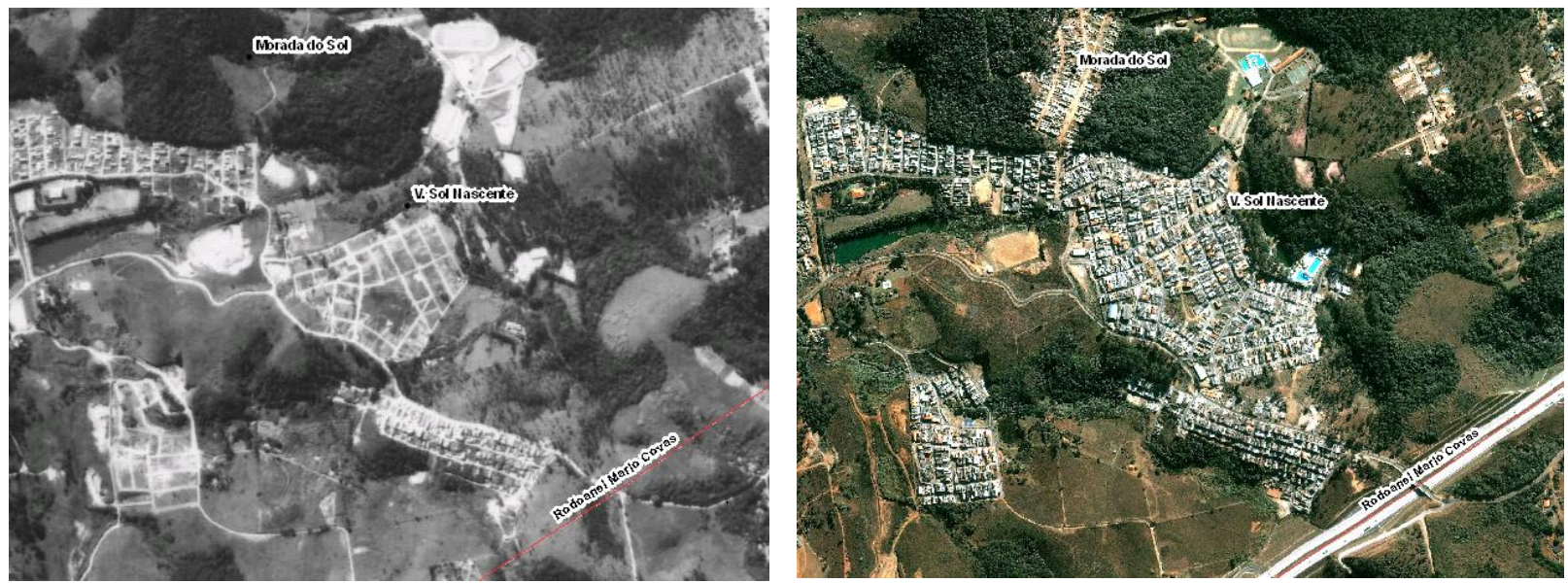

Figura 40: Morada do Sol e Vila Sol Nascente em 1994 Figura 41: Morada do Sol e Vila Sol Nascente em 2002 Organizado pela autora Fonte: LASERE (1994) e FUNCATE (2002) 
Estas vilas vêm sendo dotadas de melhorias como praças (Foto 18), infra-estrutura (Foto 19) para a população, as casas estão sendo reformadas com acabamentos melhores (Figuras 42 e 43) e a subprefeitura de Perus vem agindo com programas de conscientização sobre ocupações irregulares.

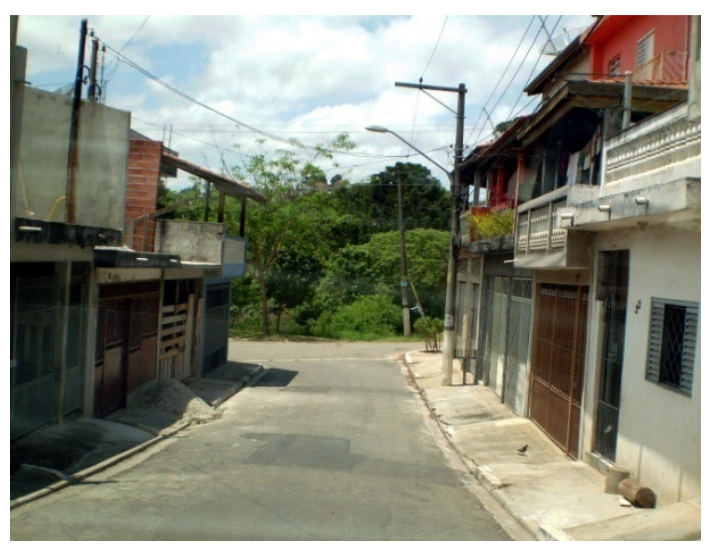

Foto 18: Morada do Sol

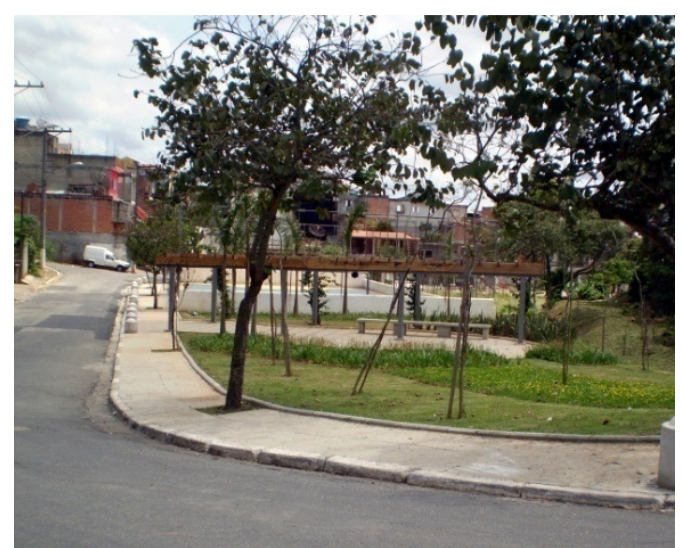

Foto 19: Nova praça na Vila Morada do Sol

Fotos da autora



\begin{tabular}{|c|}
\hline $\begin{array}{l}\text { Santos, } \\
\text { Sorada } \\
\text { n } \\
\text { ria: as } \\
\text { dos } \\
\text { Jardim }\end{array}$ \\
\hline
\end{tabular}

Figuras 42 e 43: Informes sobre melhorias nas Vilas Morada do Sol e Sol Nascente em Perus (São Paulo- SP)

Fonte: Boletim informativo Aqui Perus. Prefeitura de São Paulo. Perus, janeiro de 2009.

Uma Instituição pertencente ao Colégio Batista Brasileiro é responsável por projetos sociais com crianças da vila, mas não tem capacidade de atender toda demanda. Embora estas vilas estejam passando por algumas melhorias, não é suficiente para atender todas as necessidades da população e o crescimento não planejado da mancha urbana. Segundo entrevista, muitos moradores dependem de um precário sistema de transporte público para 
chegar aos seus locais de trabalho, em sua maioria nas vilas vizinhas. Quando se questionou a utilização do Rodoanel, os moradores dizem não ter muito acesso a esta rodovia, pois não possuem carro.

A Vila Santa Cruz é uma ocupação localizada próxima a galpões da antiga Fábrica de Cimento Perus, à área de mineração e próxima a Avenida Raimundo P. de Magalhães que dá acesso a uma área industrializada. Na década de 1990 esta vila já existia e uma alteração possível de se observar em análise comparativa entre as imagens aéreas dos anos de 1994 e 2002, é o avanço da área de mineração em direção à vila (Figuras 44 e 45).
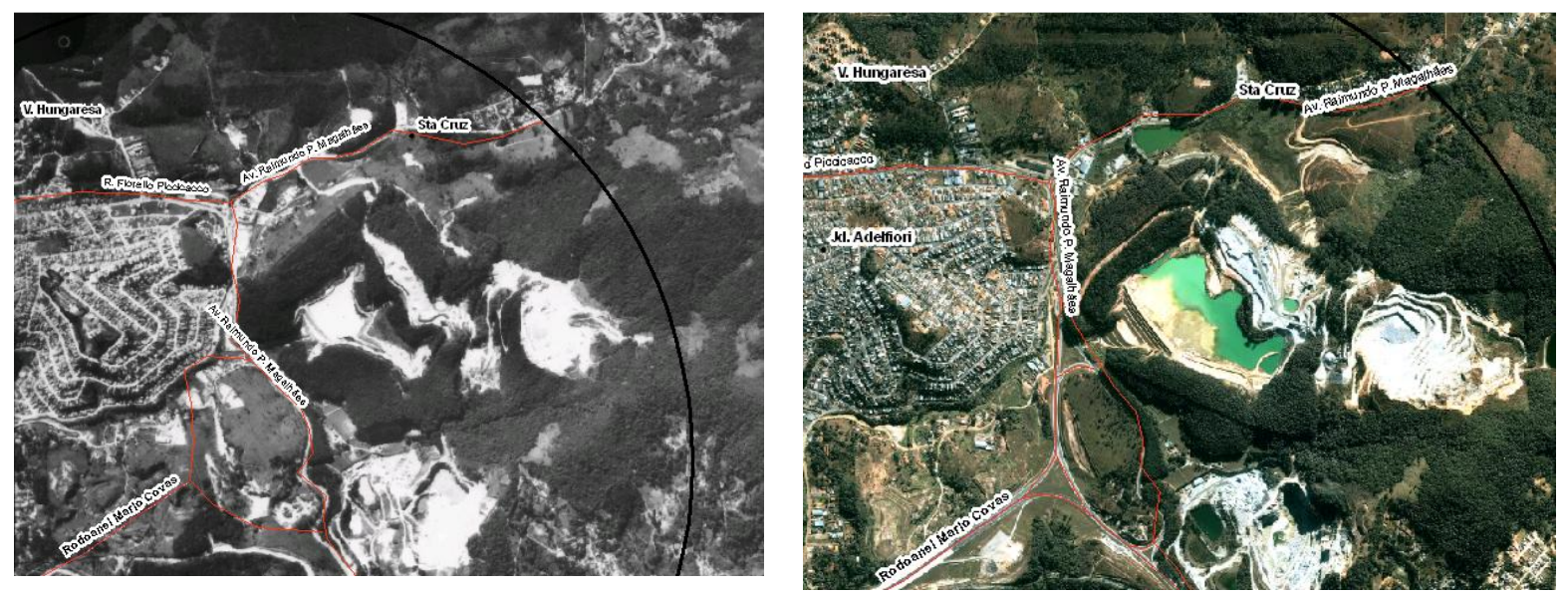

Figura 44: Vila Hungaresa, Jardim Santa Cruz em 1994 Figura 45: Vila Hungaresa, Jardim Santa Cruz em 2002 Organizado pela autora

Fonte: LASERE (1994) e FUNCATE (2002)

\subsubsection{Jaraguá}

No bairro Jaraguá também existem vilas que cresceram a partir da dinâmica ferroviária e, posteriormente, das rodovias.

A estação foi aberta em 1891 com o nome de Taipas, e era conhecida como Parada de Taipas. Em meados dos anos 40, teve o nome alterado para Jaraguá, que era o nome de um posto telegráfico situado um quilômetro antes, sentido Capital-Jundiaí. O seu prédio ainda é antigo (provavelmente não o da inauguração). Em 28/10/83, um incêndio provocado pelos usuários descontentes com os atrasos do trem de subúrbio danificou seriamente a estação, assim como a de Caieiras. No início de 1984, começou a ser restaurada. O prédio hoje mantém as suas características originais e atende aos trens metropolitanos da CPTM (HAHMANN et al, 2004) 
O Jardim Ipanema é um exemplo que se pode citar, tendo sua origem a partir da ferrovia e suas atividades. Atualmente, é uma vila consolidada, com infra-estrutura básica, as casas são de alvenaria, em sua maioria reformadas.

Existem algumas áreas de expansão da vila que são mais carentes, como a área localizada em frente a Vila Homero (Foto 20), ocupada mais recentemente. Outra área de ocupação recente é aquela situada ao norte, onde atualmente existem conjuntos residenciais verticais, próximo a Rodovia dos Bandeirantes (Figuras 46 e 47).

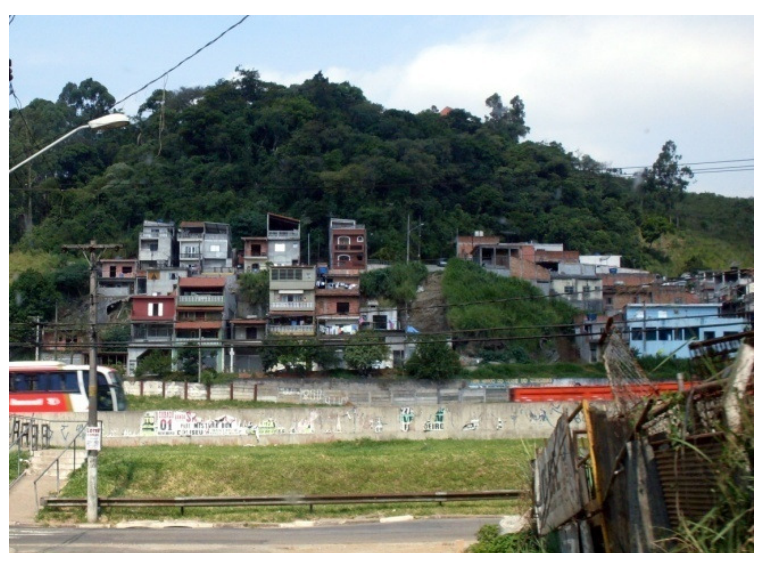

Foto 20: Jardim Ipanema visto da Vila Homero Foto da autora

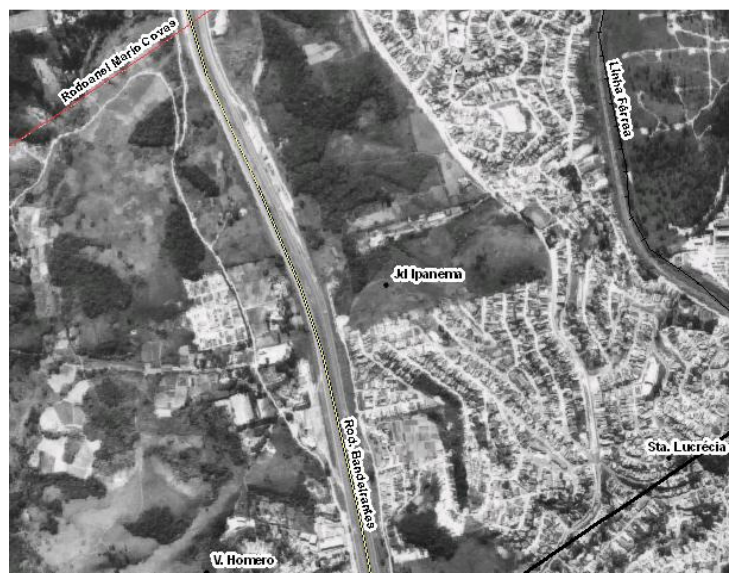

Figura 46: Jardim Ipanema e Vila Homero em 1994

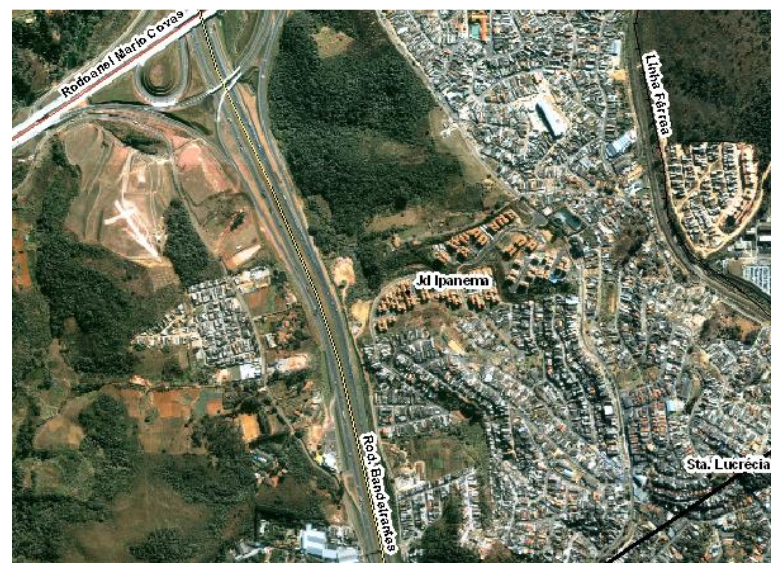

Figura 47: Jardim Ipanema e Vila Homero em 2002 Organizado pela autora Fonte: LASERE (1994) e FUNCATE (2002)

A ocupação do Jardim Itaberaba já havia iniciado em 1994, ao norte iniciou posteriormente o Jardim Itaberaba II, e ao sul ao Jardim Esperança (Figuras 48 e 49). 


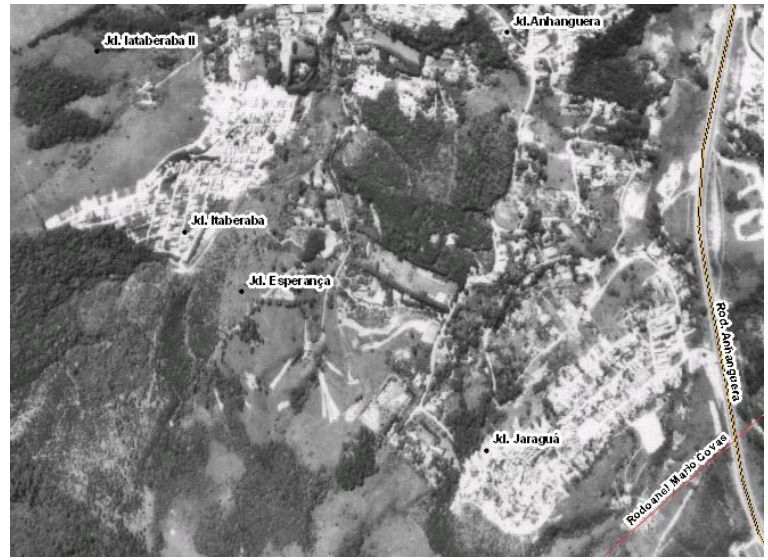

Figura 48: Jardim Itaberaba, Jardim Itaberaba II, Jardim Anhanguera, Jardim Esperança, Jardim Jaraguá em 1994

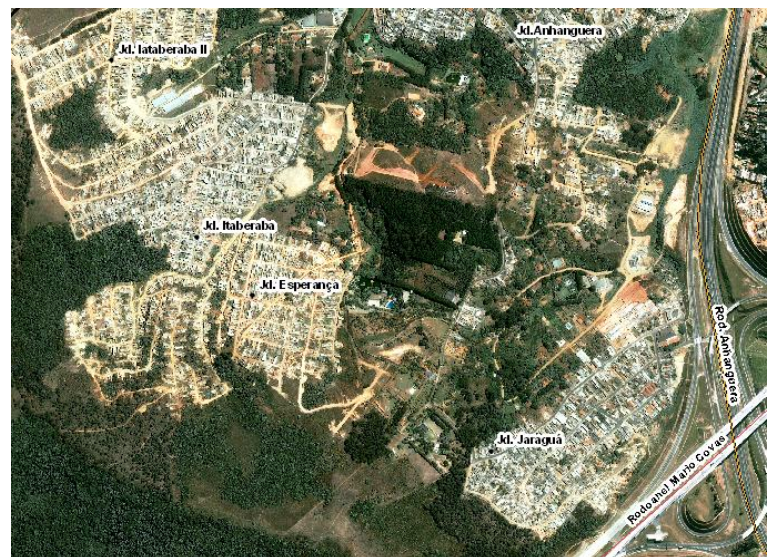

Figura 49: Jardim Itaberaba, Jardim Itaberaba II, Jardim Anhanguera, Jardim Esperança, Jardim Jaraguá em 2002

Organizado pela autora

Fonte: LASERE (1994) e FUNCATE (2002)

As duas vilas cresceram em terrenos acidentados, desprovidas de planejamento, e atualmente são vilas carentes de infra-estrutura, áreas densamente ocupadas por casas com materiais de baixa qualidade (embora seja de alvenaria), escassez de espaços de lazer e equipamentos de serviços públicos. Existem fragmentos de mata, mas não são considerados áreas de lazer, pois a população do local os vê como empecilhos, locais para descarte de lixo, que contribuem para ações de assaltantes. Nas duas vilas (Fotos 21 e 22), é nítido o avanço da ocupação residencial em direção a estes fragmentos de mata.

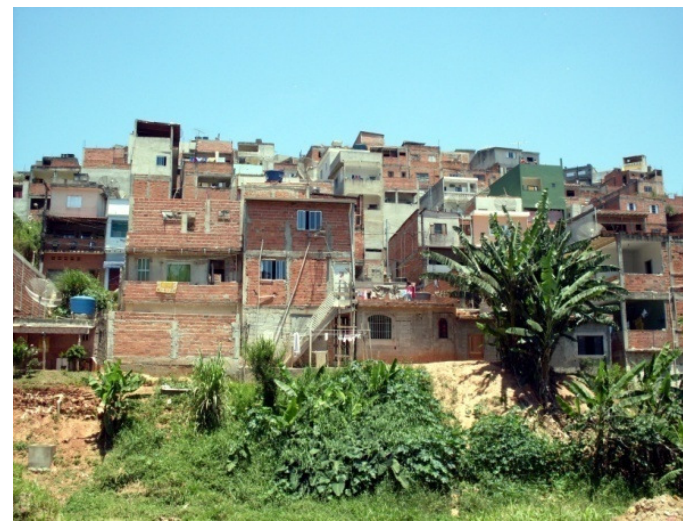

Foto 21: Jardim Esperança



Foto 22: Jardim Itaberaba II

Fotos da autora

A Vila Homero (Foto 23) é uma ocupação residencial com casas de materiais de baixa qualidade, uma vila dotada de alguma infra-estrutura com asfalto e iluminação pública. É uma ocupação muito próxima a rodovia dos Bandeirantes, tendo acesso formal para automóveis e 
passarela para pedestres. Nesta vila, observa-se residência e galpões na marginal da rodovia dos Bandeirantes e espaços sem ocupação. Trata-se um terreno acidentado, mas a ocupação ocorre em lugares mais planos perto da rodovia, é também uma vila muito próxima ao Parque do Pico do Jaraguá (Área de Proteção Ambiental).

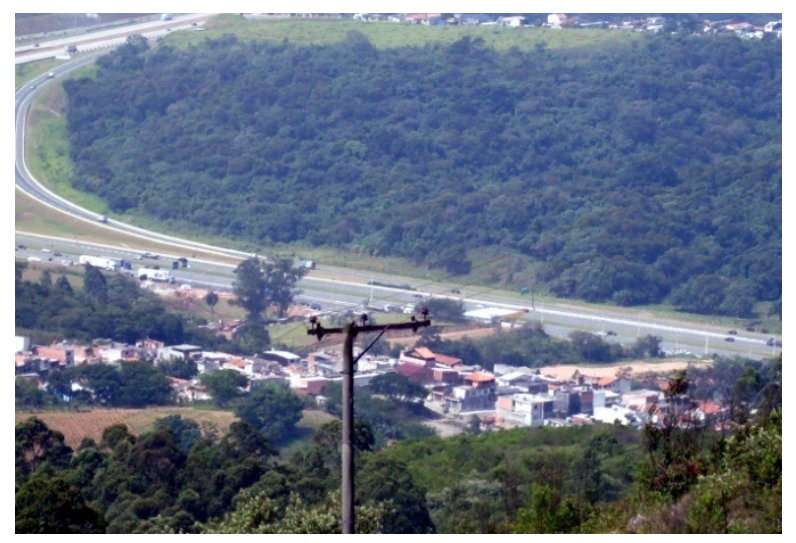

Foto 23: Vila Homero

Foto da autora

Em análise às imagens aéreas de 1994 e 2002 e em trabalhos de campo nos últimos quatro anos não foram registradas significantes alterações ou expansão da vila (Figuras 50 e $51)$.

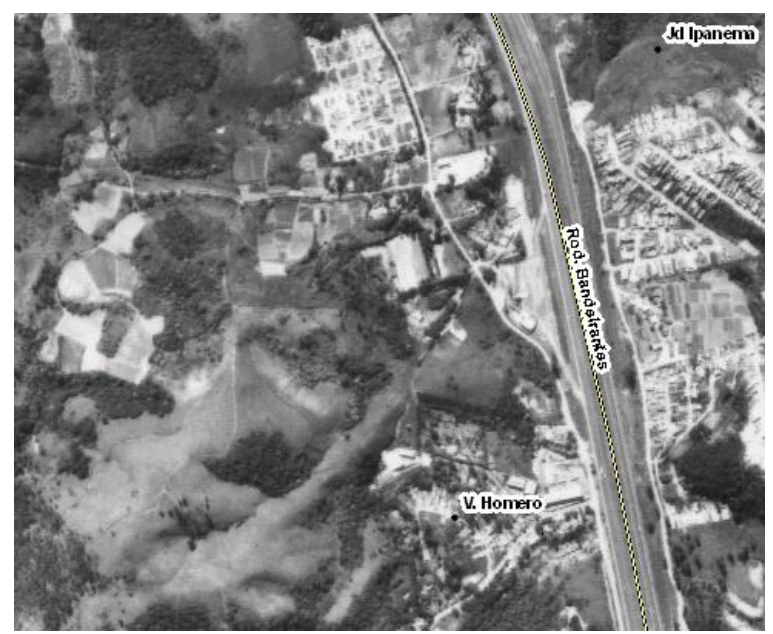

Figura 50: Jardim Ipanema em 1994

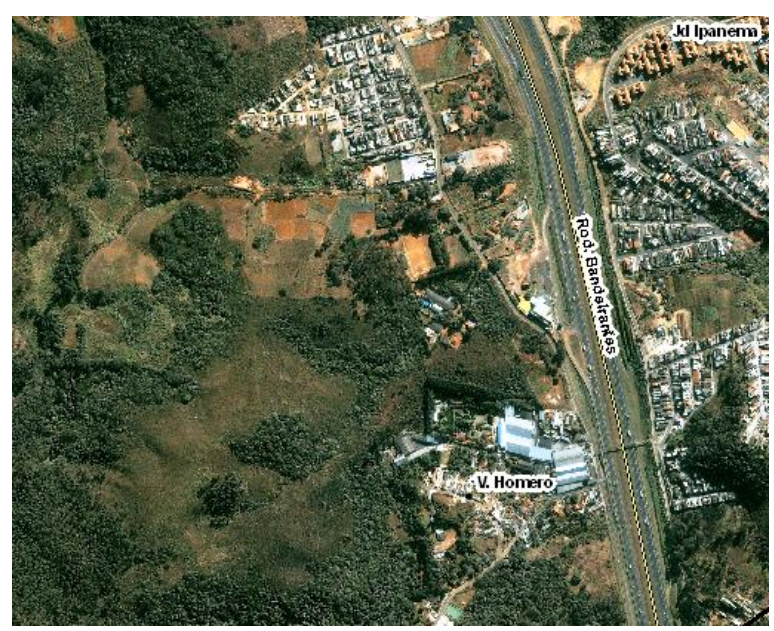

Figura 51: Jardim Ipanema em 2002

Organizado pela autora

Fonte: LASERE (1994) e FUNCATE (2002) 
O Jardim Sta Lucrecia é uma ocupação residencial densamente ocupada, uma vila já consolidada que se originou a partir das atividades da ferrovia e das indústrias presentes em suas proximidades.

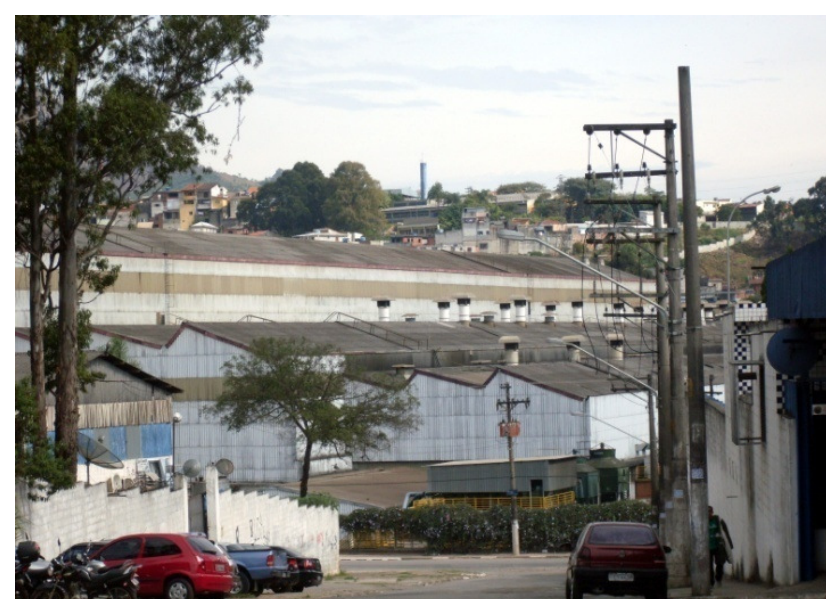

Foto 24: Indústria e ocupação residencial no entorno (Jardim Ipanema e Jardim Sta Lucrecia) Foto da autora

Logo após o declínio das atividades ferroviárias, a construção da rodovia Bandeirantes continuou a atrair empresas e movimentar a dinâmica das vilas como Jardim Santa Lucrecia, Jardim Ipanema e Vila Aurora. Em 1994, a área nas proximidades da indústria metalúrgica que atualmente é ocupada por conjunto de prédios (Figura 52) era antes sem ocupação (Figura 53).

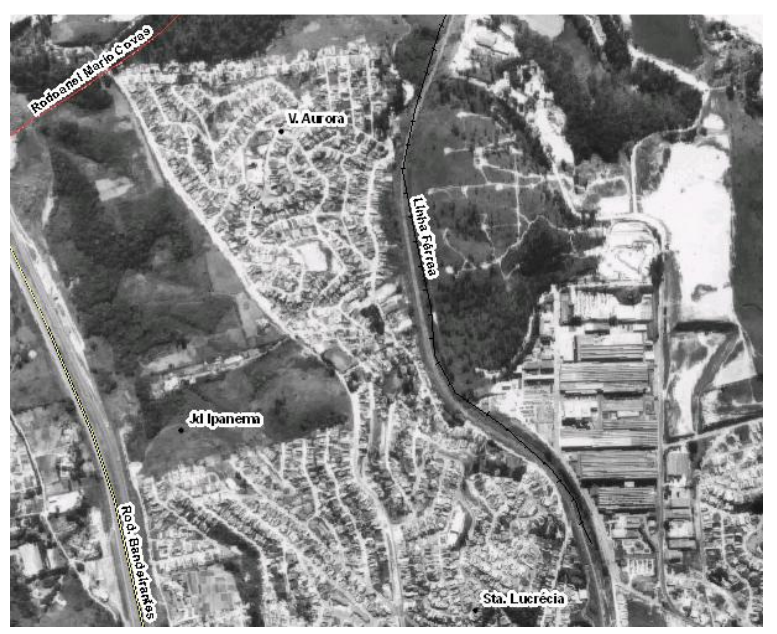

Figura 52: Jardim Ipanema, Vila Aurora, Vila Santa Lucrecia em 1994



Figura 53: Jardim Ipanema, Vila Aurora, Vila Santa Lucrecia em 2002

Organizado pela autora

Fonte: LASERE (1994) e FUNCATE (2002) 
O Jardim Rincão é uma vila consolidada desde a década de 1990, próximo a Avenida Raimundo Pereira de Magalhães, acesso a antiga Estrada Velha de Campinas, muito utilizada no trajeto São Paulo a Campinas antes da construção das rodovias Anhanguera e Bandeirantes; próximo também ao bairro Parada de Taipas, um bairro consolidado, existente a mais de 100 anos. Em 1994, o Jardim Rincão mostrava-se consolidado, com presença de galpões industriais (Figura 54).

Nas proximidades do bairro, entorno de uma indústria metalúrgica, ao lado da linha férrea da CPTM, é visto que houve grande modificações no espaço como a construção de conjuntos residenciais (Foto 25) onde antes havia área com solo exposto e gramínea (Figura 55), e o surgimento de uma nova ocupação entre uma indústria metalúrgica e a linha férrea, onde antes havia densa área verde (Foto 26).

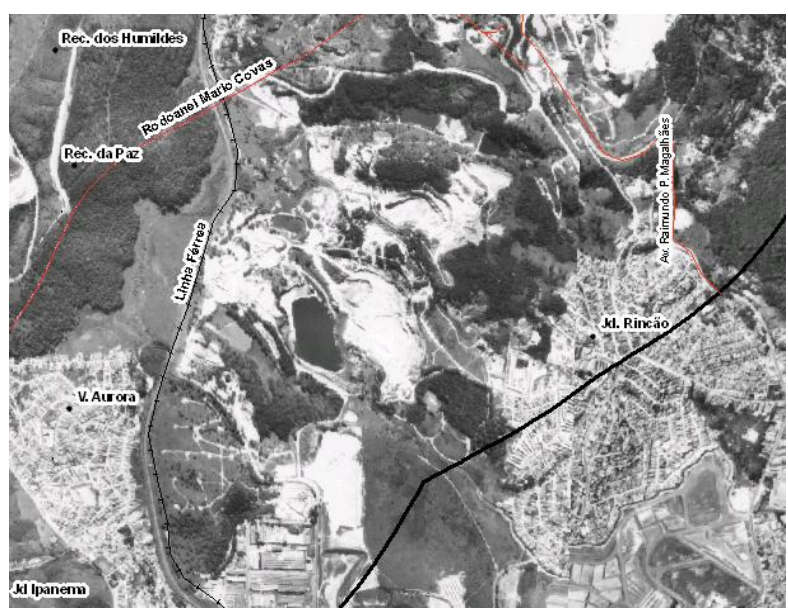

Figura 54: Jardim Rincão, Recanto da Paz, Recanto dos Humildes e Jardim Ipanema em 1994



Figura 55: Jardim Rincão, Recanto da Paz, Recanto dos Humildes e Jardim Ipanema em 2002

Organizado pela autora

Fonte: LASERE (1994) e FUNCATE (2002)

Em trabalho de campo foi visto que esta nova ocupação é recente, desprovida de planejamento e carente de infra-estrutura. 


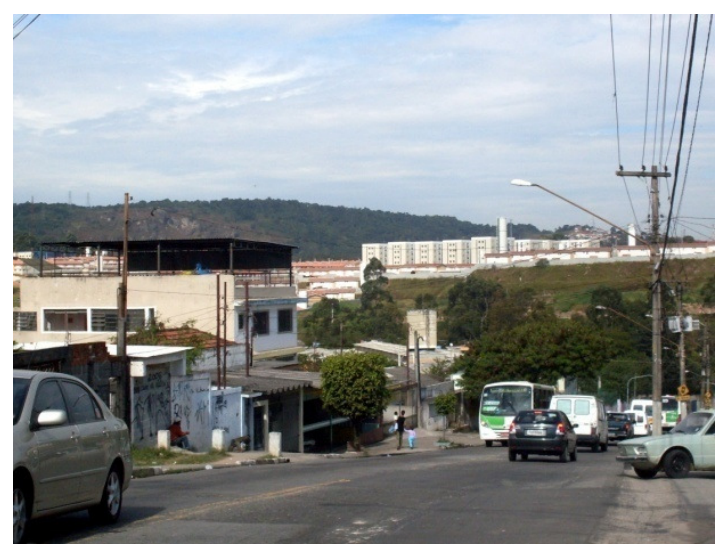

Foto 25: Jardim Rincão (prédios ao fundo)

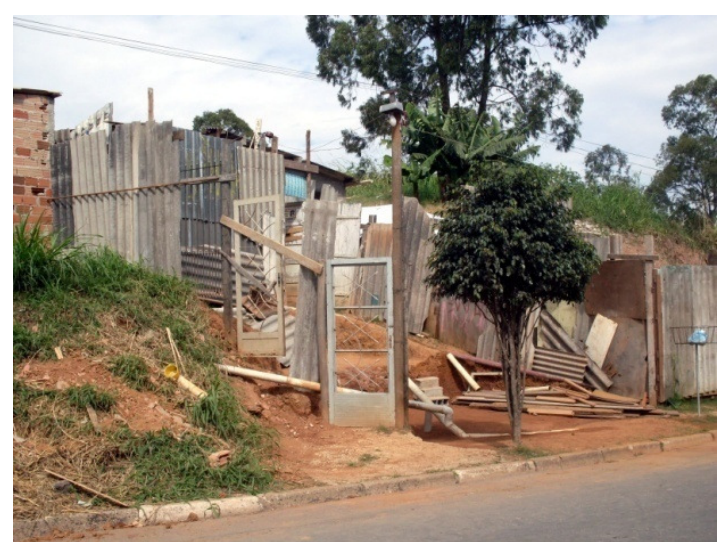

Foto 26: Ocupação irregular

Fotos da autora

\subsubsection{Osasco}

O Jardim Santa Fé, embora a área estudada ainda esteja antes do final do túnel de acesso a Osasco, já pertence a este município. Trata-se de uma área densamente ocupada por indústrias e empresas segundo análise de imagens aéreas do ano de 2002 e entrevistas com moradores do local. A rodovia Anhanguera e a proximidade com a rodovia Castello Branco foram os fatores relevantes para as indústrias se instalarem em suas proximidades; e também o fato de Osasco ser um município de características industriais, como visto anteriormente. $\mathrm{Na}$ década de 1990 observa-se uma ocupação industrial menos densa, de acordo com análise de imagens aéreas da época.

O Jardim Santa Fé em 1994 ainda não era muito ocupado, embora haja indícios de ruas, terrenos e algumas construções (Figura 56). Em 2002 observa-se maior ocupação industrial, principalmente próxima a rodovia Anhanguera, e casas (Figura 57). Em trabalho de campo foi observada a presença de chácaras e galpões industrias em meio a fragmentos de mata. 




Figura 56: Jardim Santa Fé no município de Osasco em 1994

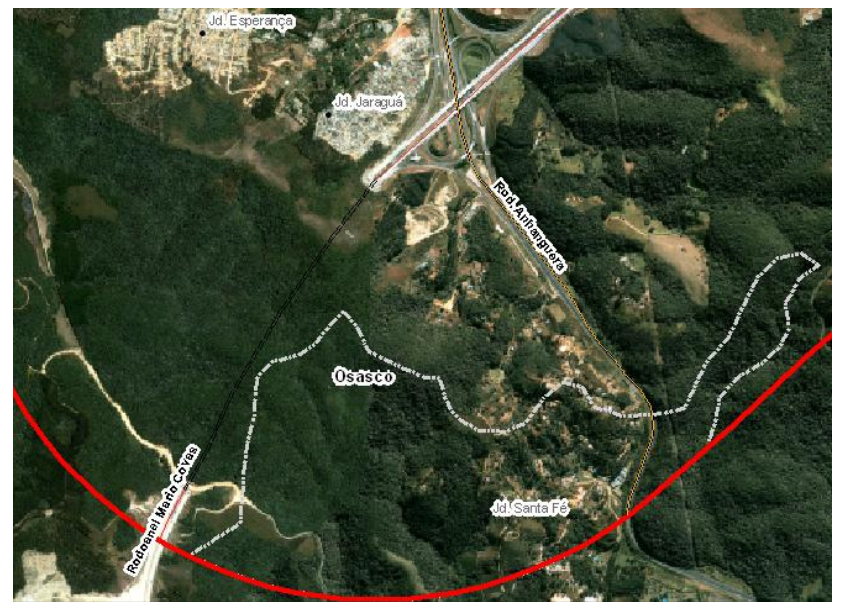

Figura 57: Jardim Santa Fé no município de Osasco em 2002

Organizado pela autora

Fonte: LASERE (1994) e FUNCATE (2002)

A seguir são apresentadas as fotos referentes às informações coletadas em trabalhos de campo nos anos de 2006, 2007, 2008 e 2009 em uma área de 2 km no entorno do eixo viário Rodoanel Mario Covas (Foto 30 a Foto 179).

As imagens aéreas dos ano de 1994 e 2002 foram utilizadas a fim de analisar as transformações ocorridas neste intervalo e também para mostrar a localização dos locais visitados. Também foi possível observar transformações ocorridas desde 2002 até os últimos trabalhos de campo, mesmo com duas fontes distintas (dados de imagem aérea e trabalho de campo). Os pontos de referências nas imagens (Figuras 58 e 59) são os locais visitados durante os trabalhos de campo e, em cada ponto, foi considerado um buffer de 100 metros para análise do uso e ocupação do solo nesta área.

Os pontos foram escolhidos por apresentarem características distintas em diferentes vilas, segundo os primeiros trabalhos de campo investigativos realizados no ano de 2006. Aqueles pontos que apresentaram muita proximidade devido ao buffer de 100 metros foram retirados posteriormente, sendo assim, está ausente a numeração de alguns pontos. 


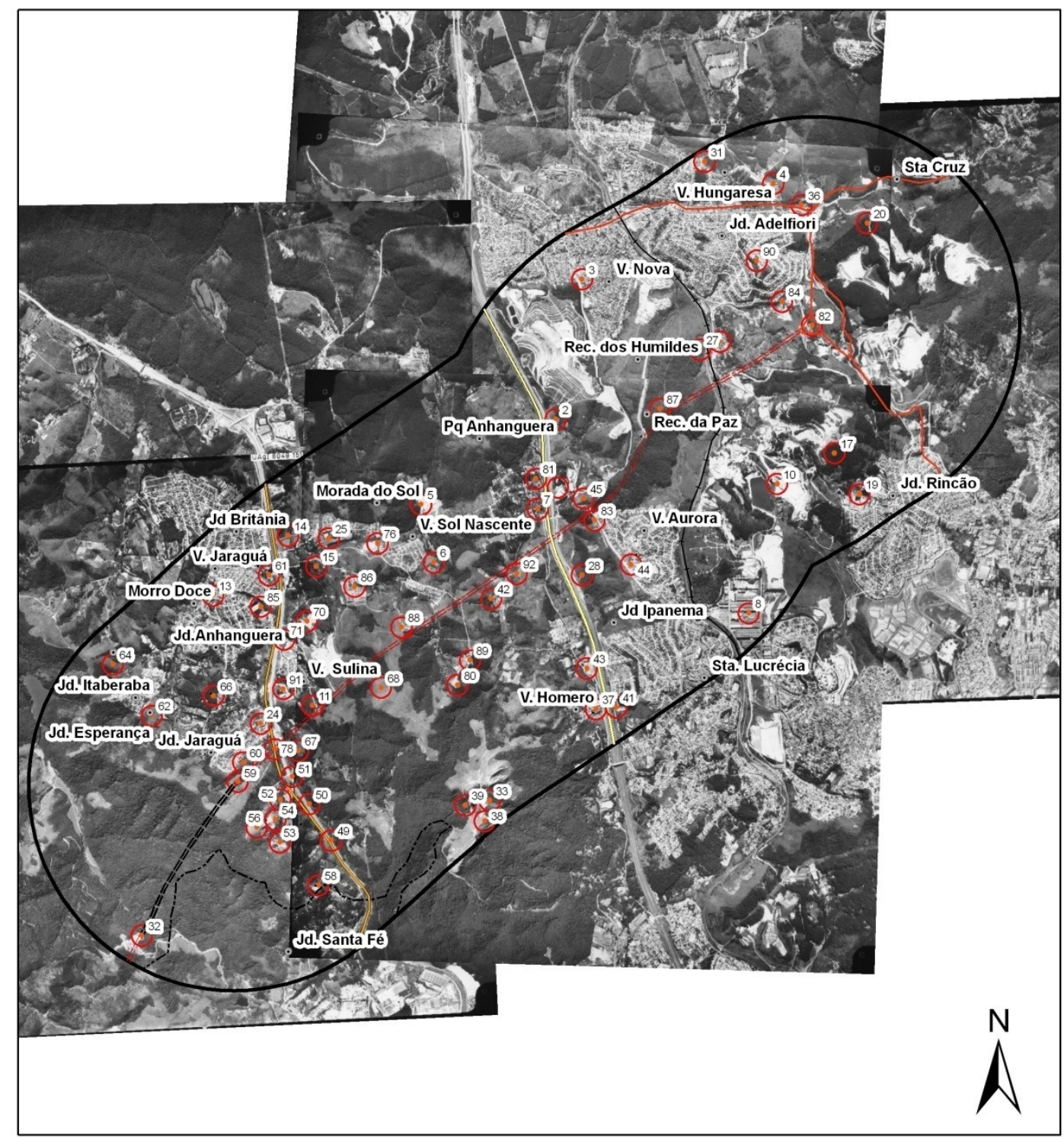

\section{Legenda}

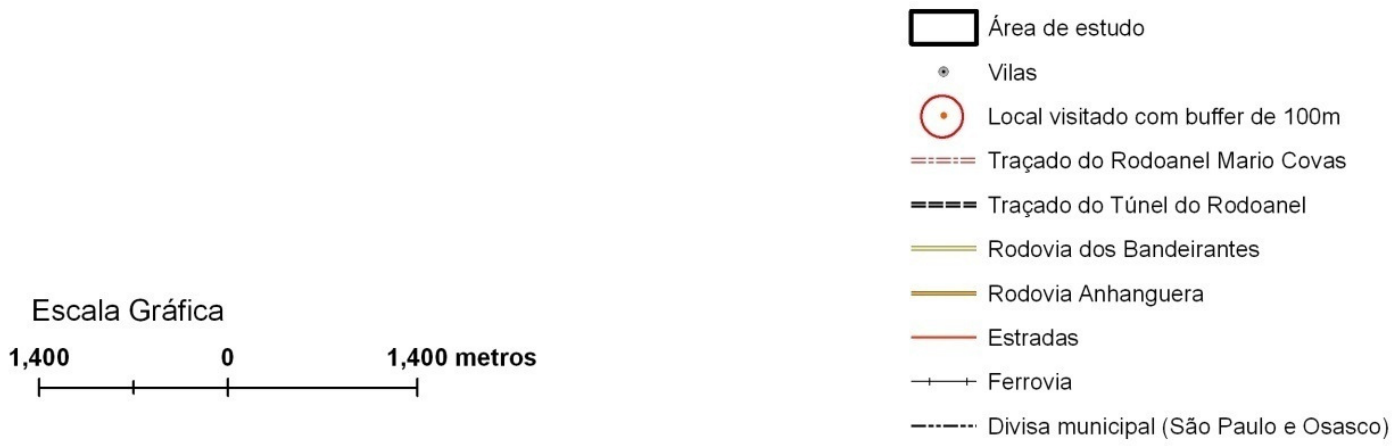

Figura 58: Pontos de referência na fotografia aérea de 1994

Elaborado e organizado pela autora

Fonte: LASERE (1994) 


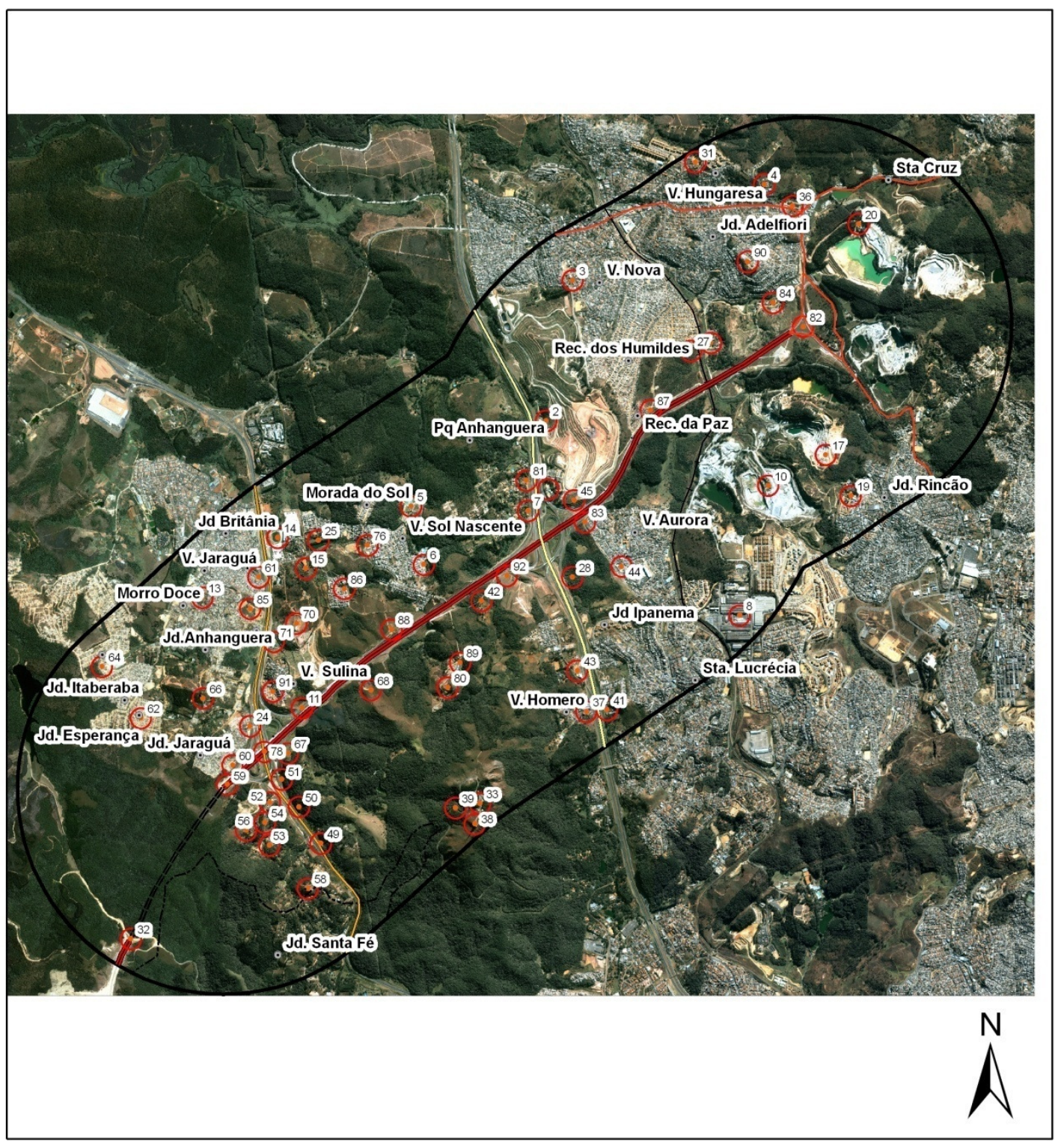

\section{Legenda}

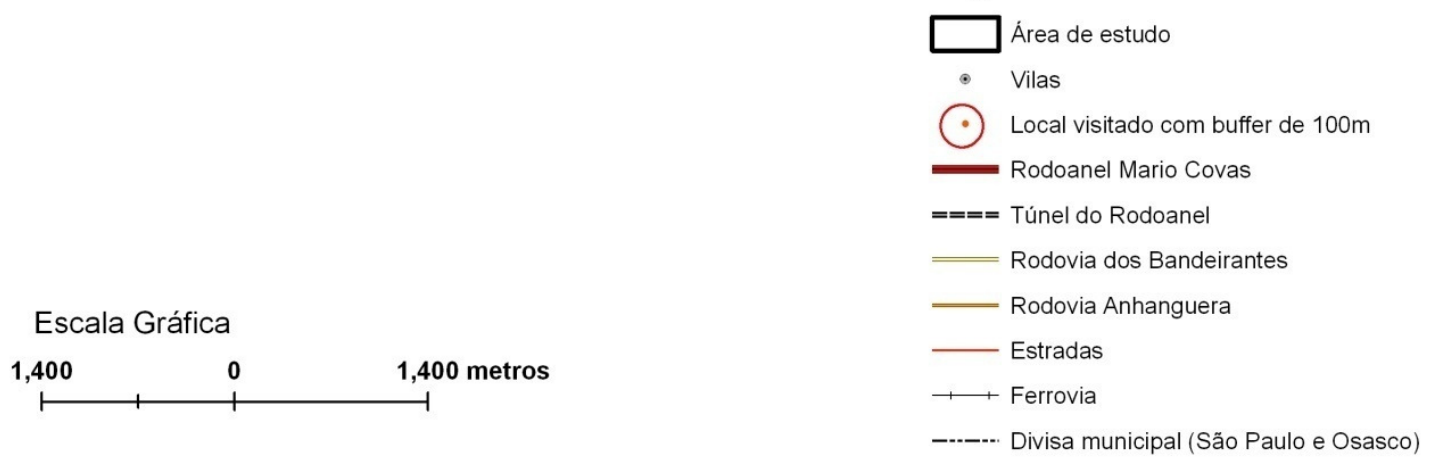

Figura 59: Pontos de referência na imagem IKONOS 2002

Elaborado e organizado pela autora

Fonte: FUNCATE (2002) 


\section{ANÁLISE NO ENTORNO DO RODOANEL MARIO COVAS TRECHO OESTE : BAIRROS DE PERUS E JARAGUÁ}

\begin{tabular}{|c|c|c|c|c|}
\hline Ano & 2006 & 2007 & 2008 & 2009 \\
\hline Referência & \multicolumn{4}{|c|}{ PONTO 2 - Aterro Sanitário - Perus } \\
\hline Fotos & Não há foto & (1) & $B=$ & Não há foto \\
\hline $\begin{array}{l}\text { Descrição das } \\
\text { fotos }\end{array}$ & & $\begin{array}{l}\text { Aterro sanitário visto de } \\
\text { uma via no bairro de Perus }\end{array}$ & $\begin{array}{l}\text { Aterro sanitário visto do } \\
\text { Rodoanel }\end{array}$ & \\
\hline Números & & Foto 27 & Foto 28 & \\
\hline $\begin{array}{l}\text { Análise da } \\
\text { imagem IKONOS } \\
2002\end{array}$ & \multicolumn{4}{|c|}{ Aterro sanitário formando um talude e uma via de acesso interna. } \\
\hline Análise de campo & \multicolumn{4}{|c|}{$\begin{array}{l}\text { Não houve transformação significativa desde } 2002 \text {, a não ser pequenas modificações operacionais ocorridas } \\
\text { dentro da própria área do aterro, ainda hoje em funcionamento. No geral, o uso e ocupação do solo atual } \\
\text { condiz com o observado em } 1994 \text { e } 2002 \text { pela imagem aérea. }\end{array}$} \\
\hline $\begin{array}{l}\text { Informações } \\
\text { complementares }\end{array}$ & \multicolumn{4}{|c|}{$\begin{array}{l}\text { A área com gramínea corresponde a uma área já utilizada e que atualmente não está mais em atividade. A } \\
\text { área com solo exposto corresponde a área utilizada em } 2002 \text { pelo aterro sanitário. }\end{array}$} \\
\hline
\end{tabular}




\begin{tabular}{|c|c|c|c|c|}
\hline Ano & 2006 & 2007 & 2008 & 2009 \\
\hline Referência & \multicolumn{4}{|c|}{ PONTO 3 - Vila Nova - Perus } \\
\hline Fotos & Não há fotc & & & \\
\hline $\begin{array}{l}\text { Descrição das } \\
\text { fotos }\end{array}$ & & $\begin{array}{l}\text { Ocupação residencial e } \\
\text { comércios }\end{array}$ & Escola Pública & $\begin{array}{l}\text { Ocupação residencial e } \\
\text { comércios }\end{array}$ \\
\hline Números & & Foto 29 & Foto 30 & Foto 31 \\
\hline $\begin{array}{c}\text { Análise da } \\
\text { imagem IKONOS } \\
2002\end{array}$ & \multicolumn{4}{|c|}{ Galpão (Escola Pública), ocupação residencial densa em seu entorno, fragmento de mata. } \\
\hline $\begin{array}{c}\text { Análise da } \\
\text { imagem aérea } \\
1994\end{array}$ & \multicolumn{4}{|c|}{ Galpão (Escola Pública) e ocupação residencial densa em seu entorno, fragmento de mata. } \\
\hline Análise de campo & \multicolumn{4}{|c|}{$\begin{array}{l}\text { Vila consolidada. Não houve transformação significativa desde 2002, mas houve crescimento da ocupação } \\
\text { residencial desde } 1994 \text { e implantação de infra-estrutura. }\end{array}$} \\
\hline $\begin{array}{c}\text { Informações } \\
\text { complementares }\end{array}$ & \multicolumn{4}{|c|}{ Foto 30: Escola Pública Manoel Bandeira } \\
\hline
\end{tabular}




\begin{tabular}{|c|c|c|c|c|}
\hline Ano & 2006 & 2007 & 2008 & 2009 \\
\hline Referência & \multicolumn{4}{|c|}{ PONTO 4 - Vila Jardim Adelfiori - Perus } \\
\hline Fotos & Não há foto & vão há fo & & \\
\hline $\begin{array}{l}\text { Descrição das } \\
\text { fotos }\end{array}$ & & & Delegacia de Polícia & Escola pública \\
\hline Números & & & Foto 32 & Foto 33 \\
\hline $\begin{array}{l}\text { Análise da } \\
\text { imagem IKONOS } \\
2002 \\
\end{array}$ & \multicolumn{4}{|c|}{ Galpões (escolas, delegacia e outros prédios públicos), fragmento de mata. } \\
\hline $\begin{array}{l}\text { Análise da } \\
\text { imagem aérea } \\
1994\end{array}$ & \multicolumn{4}{|c|}{ Galpões (escolas, delegacia e outros prédios públicos), fragmento de mata. } \\
\hline Análise de campo & \multicolumn{4}{|c|}{$\begin{array}{l}\text { Galpões destinados a serviços para a população (delegacia e escolas) que atendem o bairro de Perus, } \\
\text { fragmento de mata. Houve aumento na ocupação residencial e na infra-estrutura desde 1994, mas ainda } \\
\text { assim, é uma vila carente. }\end{array}$} \\
\hline $\begin{array}{c}\text { Informações } \\
\text { complementares }\end{array}$ & \multicolumn{4}{|c|}{ Foto 33: Escola Pública Julio de Oliveira } \\
\hline
\end{tabular}




\begin{tabular}{|c|c|c|c|c|}
\hline Ano & 2006 & 2007 & 2008 & 2009 \\
\hline Referências & \multicolumn{4}{|c|}{ PONTO 5 - Vila Sol Nascente $\left(12^{\circ}\right.$ Gleba $)$ - Perus } \\
\hline Fotos & Não há foto & Não há foto & Não há foto & \\
\hline $\begin{array}{l}\text { Descrição das } \\
\text { fotos }\end{array}$ & & & & $\begin{array}{l}\text { Centro Educacional, } \\
\text { Social e Esportivo } \\
\text { (CESE) do Colégio } \\
\text { Batista Brasileiro }\end{array}$ \\
\hline $\begin{array}{l}\text { Números das } \\
\text { fotos }\end{array}$ & & & & Foto $34^{25}$ \\
\hline $\begin{array}{c}\text { Análise da } \\
\text { imagem IKONOS } \\
2002\end{array}$ & \multicolumn{4}{|c|}{ Terreno, construções (CESE) e fragmento de mata. } \\
\hline $\begin{array}{c}\text { Análise da } \\
\text { imagem aérea } \\
1994\end{array}$ & \multicolumn{4}{|c|}{ Galpões (Colégio), gramínea e fragmento de mata.. } \\
\hline Análise de campo & \multicolumn{4}{|c|}{$\begin{array}{l}\text { O Centro (CESE) desenvolve projetos sociais coma as crianças da vila Sol Nascente e é mantido pelo } \\
\text { Colégio Batista Brasileiro. O colégio já existia em } 1994 \text { e passou por algumas reformas e reestruturações } \\
\text { para atender a população, segundo a coordenadora. Não houve transformação significativa desde } 2002 .\end{array}$} \\
\hline $\begin{array}{c}\text { Informações } \\
\text { complementares }\end{array}$ & \multicolumn{4}{|c|}{ Foi realizada entrevista com a coordenadora do Centro e visita ao local em 2009.} \\
\hline
\end{tabular}

\footnotetext{
${ }^{25}$ Foto do site do CESE indicado pela coordenadora do Centro Larissa. Disponível em: http://www.batistabrasileiro.com.br/portal/institucional_cese.asp. Acesso em 02 jun
} 2009. 


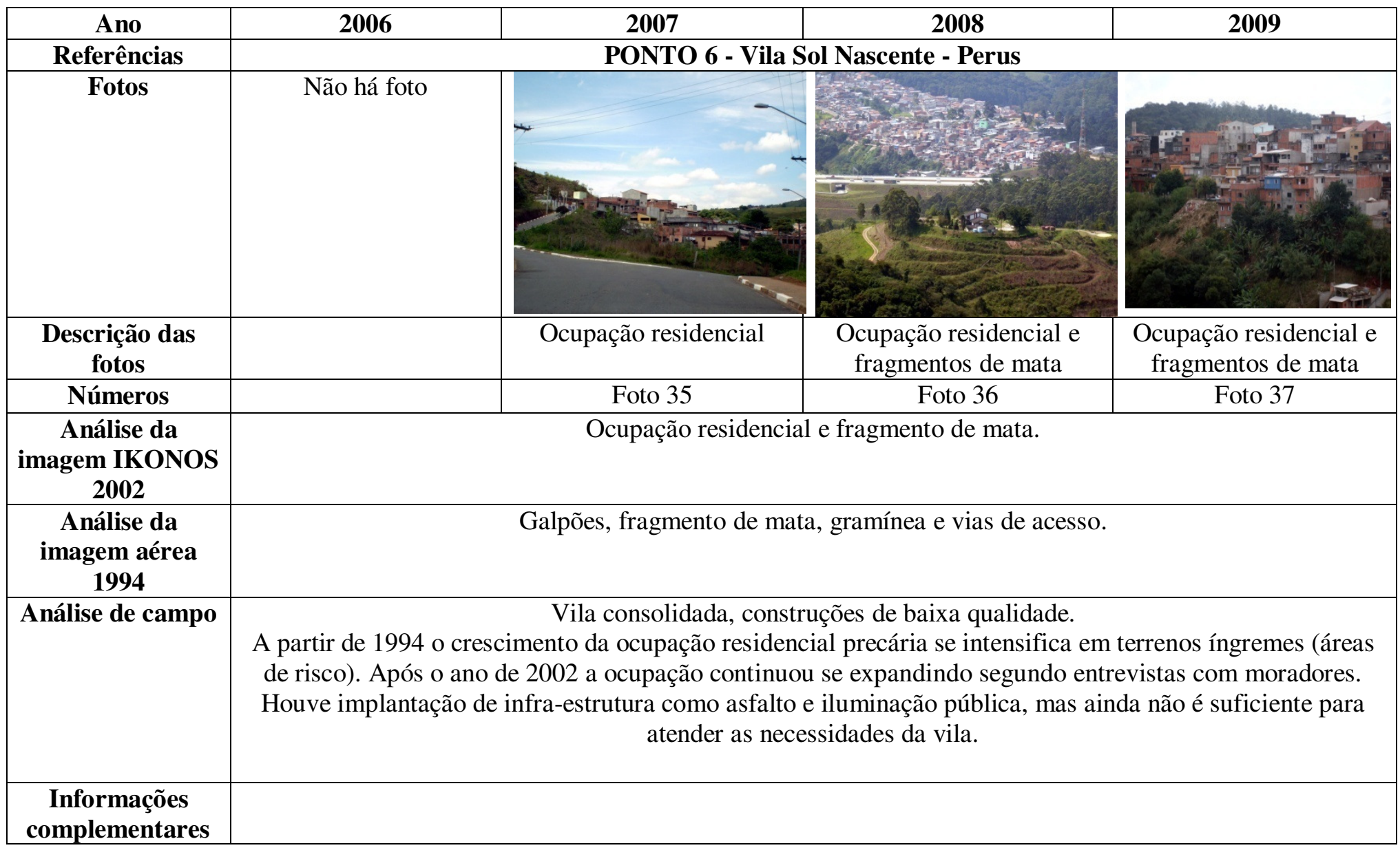




\begin{tabular}{|c|c|c|c|c|}
\hline Ano & 2006 & 2007 & 2008 & 2009 \\
\hline Descrição & \multicolumn{4}{|c|}{ PONTO 7 - Condomínios e casas de alto padrão - Perus } \\
\hline Fotos & Não há foto & & & \\
\hline $\begin{array}{l}\text { Descrição das } \\
\text { fotos }\end{array}$ & & $\begin{array}{l}\text { Casas de alto padrão e } \\
\text { fragmento de mata }\end{array}$ & $\begin{array}{l}\text { Casas de alto padrão e } \\
\text { fragmento de mata }\end{array}$ & $\begin{array}{l}\text { Casas de alto padrão e } \\
\text { fragmento de mata }\end{array}$ \\
\hline Números & & Foto 38 & Foto 39 & Foto 40 \\
\hline Fotos & Não há foto & & & \\
\hline $\begin{array}{l}\text { Descrição das } \\
\text { fotos }\end{array}$ & & & $\begin{array}{l}\text { Corpo d'água ao lado da } \\
\text { via de acesso local }\end{array}$ & Casas, árvores \\
\hline Números & & & Foto 41 & Foto 42 \\
\hline $\begin{array}{l}\text { Análise da } \\
\text { imagem IKONOS } \\
2002\end{array}$ & \multicolumn{4}{|c|}{$\begin{array}{l}\text { Rodovia (Bandeirantes) com via de acesso formal , ocupação residencial com casas esparsas de alto padrão, } \\
\text { fragmento de mata no entorno das casas. }\end{array}$} \\
\hline $\begin{array}{l}\text { Análise da } \\
\text { imagem aérea } \\
1994\end{array}$ & \multicolumn{4}{|c|}{ Casas, árvores, rodovia (Bandeirantes) e via de acesso formal para a rodovia. } \\
\hline Análise de campo & \multicolumn{4}{|c|}{$\begin{array}{l}\text { Casas de alto padrão, fragmento de mata, condomínios e vias de acesso locais não asfaltadas. } \\
\text { Houve crescimento na construção de casas desde 1994, mas não houve transformação significativa desde } \\
2002 \text {. }\end{array}$} \\
\hline $\begin{array}{c}\text { Informações } \\
\text { complementares }\end{array}$ & & & & \\
\hline
\end{tabular}

São Paulo 


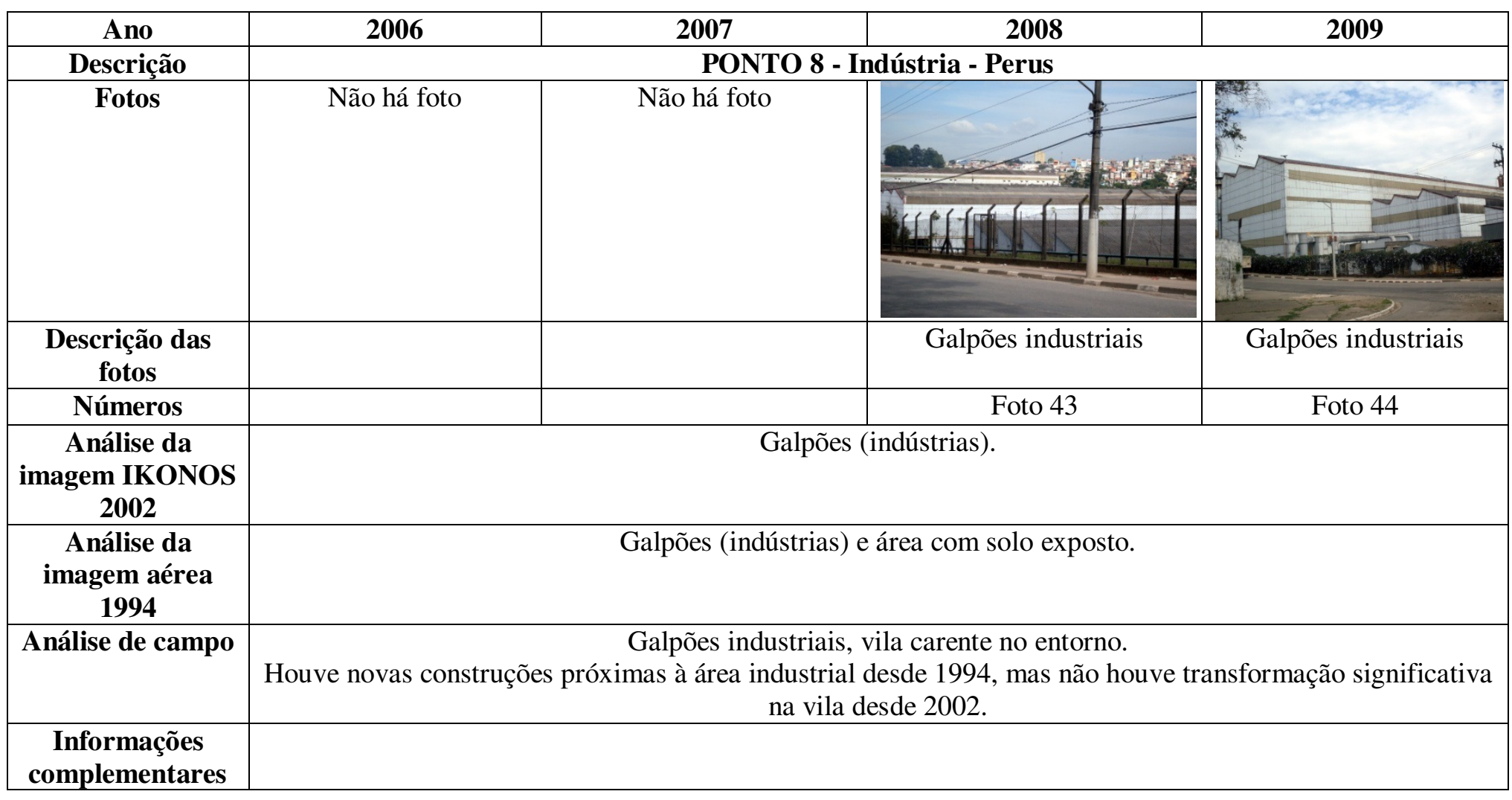




\begin{tabular}{|c|c|c|c|c|}
\hline Ano & 2006 & 2007 & 2008 & 2009 \\
\hline Descrição & \multicolumn{4}{|c|}{ PONTO 10 - Áreas de mineração - Perus } \\
\hline Fotos & & & & Não há foto \\
\hline $\begin{array}{l}\text { Descrição das } \\
\text { fotos }\end{array}$ & Cava de mineração & Cava de mineração & Cava de mineração & \\
\hline Números & Foto 45 & Foto 46 & Foto 47 & \\
\hline $\begin{array}{c}\text { Análise da } \\
\text { imagem } \\
\text { IKONOS 2002 }\end{array}$ & \multicolumn{4}{|c|}{ Cava de mineração. } \\
\hline $\begin{array}{c}\text { Análise da } \\
\text { imagem aérea } \\
1994\end{array}$ & \multicolumn{4}{|c|}{ Cava de mineração. } \\
\hline Análise de campo & \multicolumn{4}{|c|}{ Pedreira em atividade. Não houve transformação significativa desde 1994.} \\
\hline $\begin{array}{c}\text { Informações } \\
\text { complementares }\end{array}$ & & & & \\
\hline
\end{tabular}




\begin{tabular}{|c|c|c|c|c|}
\hline Ano & 2006 & 2007 & 2008 & 2009 \\
\hline Descrição & \multicolumn{4}{|c|}{ PONTO 11 - Perus } \\
\hline Fotos & Não há foto & Não há foto & & \\
\hline $\begin{array}{l}\text { Descrição das } \\
\text { fotos }\end{array}$ & & & $\begin{array}{l}\text { Início de construção da } \\
\text { praça de pedágio }\end{array}$ & $\begin{array}{l}\text { Praça de pedágio em } \\
\text { atividade }\end{array}$ \\
\hline Números & & & Foto 48 & Foto 49 \\
\hline Fotos & Não há foto & Não há foto & & Não há foto \\
\hline & & & $\begin{array}{l}\text { Praça de pedágio } \\
\text { construída }\end{array}$ & \\
\hline Números & & & Foto 50 & \\
\hline
\end{tabular}




\begin{tabular}{|c|c|c|c|c|}
\hline Ano & 2006 & 2007 & 2008 & 2009 \\
\hline Descrição & \multicolumn{4}{|c|}{ PONTO 11 - Perus } \\
\hline \multicolumn{5}{|l|}{ Fotos } \\
\hline $\begin{array}{l}\text { Descrição das } \\
\text { fotos }\end{array}$ & & & Rodoan & \\
\hline Números & & & Foto 5 & \\
\hline $\begin{array}{c}\text { Análise da } \\
\text { imagem } \\
\text { IKONOS 2002 }\end{array}$ & \multicolumn{4}{|c|}{ Rodovia (Rodoanel), alças de acesso à rodovia (Anhanguera) e taludes. } \\
\hline $\begin{array}{c}\text { Análise da } \\
\text { imagem aérea } \\
1994\end{array}$ & \multicolumn{4}{|c|}{ Construções, vias de acesso, árvores. } \\
\hline Análise de campo & \multicolumn{4}{|c|}{$\begin{array}{l}\text { A construção da praça de pedágio do Rodoanel para a rodovia Anhanguera teve início no ano de 2008. A } \\
\text { construção da rodovia Rodoanel Mario Covas e suas alças de acesso ocorreram após } 1994 .\end{array}$} \\
\hline $\begin{array}{l}\text { Informações } \\
\text { complementares }\end{array}$ & \multicolumn{4}{|c|}{$\begin{array}{l}\text { A vila avistada a frente nas fotos } 48,49 \text { e } 50 \text { chama-se Jardim Jaraguá. A foto } 51 \text { foi registrada logo na saída } \\
\text { do túnel vindo de Osasco. }\end{array}$} \\
\hline
\end{tabular}




\begin{tabular}{|c|c|c|c|c|}
\hline Ano & 2006 & 2007 & 2008 & 2009 \\
\hline Descrição & \multicolumn{4}{|c|}{ PONTO 13 - Vila Jaraguá - Jaraguá } \\
\hline Fotos & Não há foto & Não há foto & Não há foto & \\
\hline $\begin{array}{c}\text { Descrição das } \\
\text { fotos }\end{array}$ & & & & Escola pública \\
\hline Números & & & & Foto 52 \\
\hline $\begin{array}{l}\text { Análise da } \\
\text { imagem IKONOS } \\
2002\end{array}$ & \multicolumn{4}{|c|}{ Galpão (escola), árvores e ocupação residencial densa. } \\
\hline $\begin{array}{l}\text { Análise da } \\
\text { imagem aérea } \\
1994\end{array}$ & \multicolumn{4}{|c|}{ Galpão (escola), árvores e ocupação residencial densa, solo exposto. } \\
\hline Análise de campo & \multicolumn{4}{|c|}{$\begin{array}{l}\text { Escola Pública, árvores e ocupação residencial com construções de baixa qualidade no entorno. A ocupação } \\
\text { residencial se expandiu sem infra-estrutura adequada desde 1994, mas não houve transformação significativa } \\
\text { desde } 2002 .\end{array}$} \\
\hline $\begin{array}{c}\text { Informações } \\
\text { complementares }\end{array}$ & \multicolumn{4}{|c|}{ Foto 52: Escola Pública S. Q. Gusmão. } \\
\hline
\end{tabular}




\begin{tabular}{|c|c|c|c|c|}
\hline Ano & 2006 & 2007 & 2008 & 2009 \\
\hline Descrição & \multicolumn{4}{|c|}{ PONTO 14 - Extensão da Vila Sol Nascente - Perus } \\
\hline Fotos & Não há foto & Não há foto & Não há foto & \\
\hline Descrição das fotos & & & & Galpões industriais \\
\hline Números & & & & Foto 53 \\
\hline $\begin{array}{l}\text { Análise da imagem } \\
\text { IKONOS } 2002\end{array}$ & \multicolumn{4}{|c|}{ Predominância de galpões (indústrias), lago e estacionamento. } \\
\hline $\begin{array}{l}\text { Análise da imagem } \\
\text { aérea } 1994\end{array}$ & \multicolumn{4}{|c|}{ Predominância de galpões (indústrias), lago e árvores. } \\
\hline Análise de campo & \multicolumn{4}{|c|}{$\begin{array}{l}\text { Galpões industriais em funcionamento. Houve aumento na área de construções próximas aos galpões desde 1994, } \\
\text { mas não houve transformações significativa desde 2002. Em visita ao local, o lago não foi avistado. }\end{array}$} \\
\hline $\begin{array}{c}\text { Informações } \\
\text { complementares }\end{array}$ & & & & \\
\hline
\end{tabular}




\begin{tabular}{|c|c|c|c|c|}
\hline Ano & 2006 & 2007 & 2008 & 2009 \\
\hline Descrição & \multicolumn{4}{|c|}{ PONTO 15 - Vila Sol Nascente (Gleba 12) - Perus } \\
\hline Fotos & Não há foto & Não há foto & Não há foto & \\
\hline Descrição das fotos & & & & Propriedade particular \\
\hline Números & & & & Foto 54 \\
\hline Fotos & & & & \\
\hline Descrição das fotos & & & & Galpão em construcão \\
\hline Números & & & & Foto 55 \\
\hline $\begin{array}{l}\text { Análise da imagem } \\
\text { IKONOS } 2002\end{array}$ & \multicolumn{4}{|c|}{ Galpões, árvores, terreno com solo exposto, ruas asfaltadas. } \\
\hline $\begin{array}{l}\text { Análise da imagem } \\
\text { aérea } 1994\end{array}$ & \multicolumn{4}{|c|}{ Fragmento de mata e solo exposto. } \\
\hline Análise de campo & \multicolumn{4}{|c|}{$\begin{array}{l}\text { Houve crescimento na ocupação residencial desde 1994. Segundo entrevista com moradores, a infra- } \\
\text { estrutura da vila vem melhorando desde 2002. Onde havia terreno com solo exposto em } 2002 \text { na área de } \\
\text { observação, atualmente há ocupação residencial. Na saída da vila, onde antes havia gramínea, atualmente há } \\
\text { um prédio em construção. }\end{array}$} \\
\hline $\begin{array}{c}\text { Informações } \\
\text { complementares }\end{array}$ & \multicolumn{4}{|c|}{ Foto 54: Portão indicando acesso restrito para propriedade privada, ocupação residencial, ruas asfaltadas. } \\
\hline
\end{tabular}




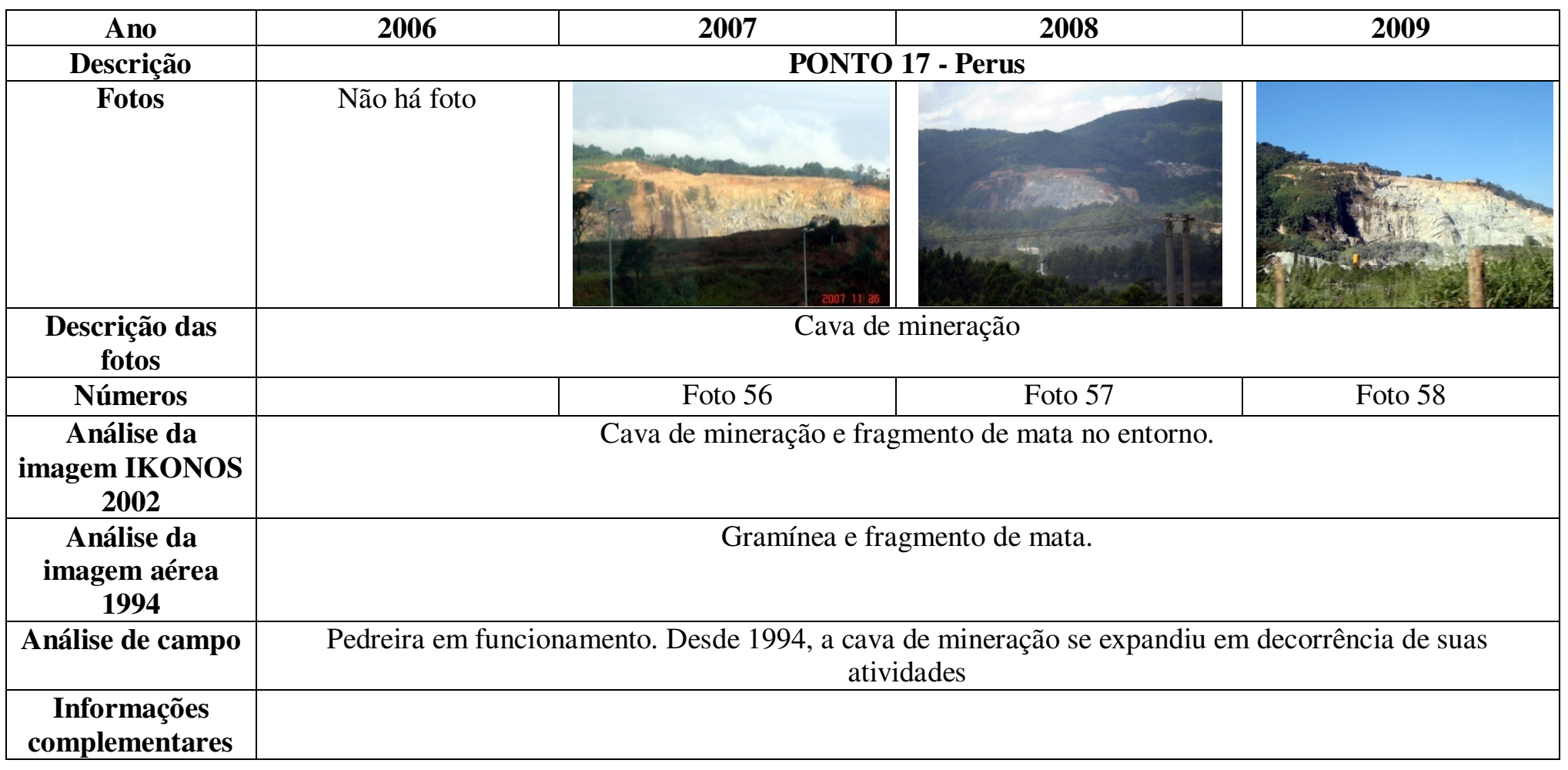




\begin{tabular}{|c|c|c|c|c|}
\hline Ano & 2006 & 2007 & 2008 & 2009 \\
\hline Descrição & \multicolumn{4}{|c|}{ PONTO 19 - Jardim Rincão - Perus } \\
\hline Fotos & Não há foto & Não há foto & Não há foto & \\
\hline $\begin{array}{l}\text { Descrição das } \\
\text { fotos }\end{array}$ & & & & $\begin{array}{l}\text { Casas, comércio, rua } \\
\text { asfaltada }\end{array}$ \\
\hline Números & & & & Foto 59 \\
\hline $\begin{array}{c}\text { Análise da } \\
\text { imagem IKONOS } \\
2002\end{array}$ & \multicolumn{4}{|c|}{ Ocupação residencial (casas e prédios), árvores e galpões. } \\
\hline $\begin{array}{c}\text { Análise da } \\
\text { imagem aérea } \\
1994\end{array}$ & \multicolumn{4}{|c|}{ Ocupação residencial, galpões e fragmentos de mata. } \\
\hline Análise de campo & \multicolumn{4}{|c|}{$\begin{array}{l}\text { Vila consolidada, árvores, comércio, infra-estrutura. Houve crescimento da ocupação residencial e na infra- } \\
\text { estrutura desde 1994, mas não houve transformação significativa desde } 2002 .\end{array}$} \\
\hline $\begin{array}{c}\text { Informações } \\
\text { complementares }\end{array}$ & & & & \\
\hline
\end{tabular}




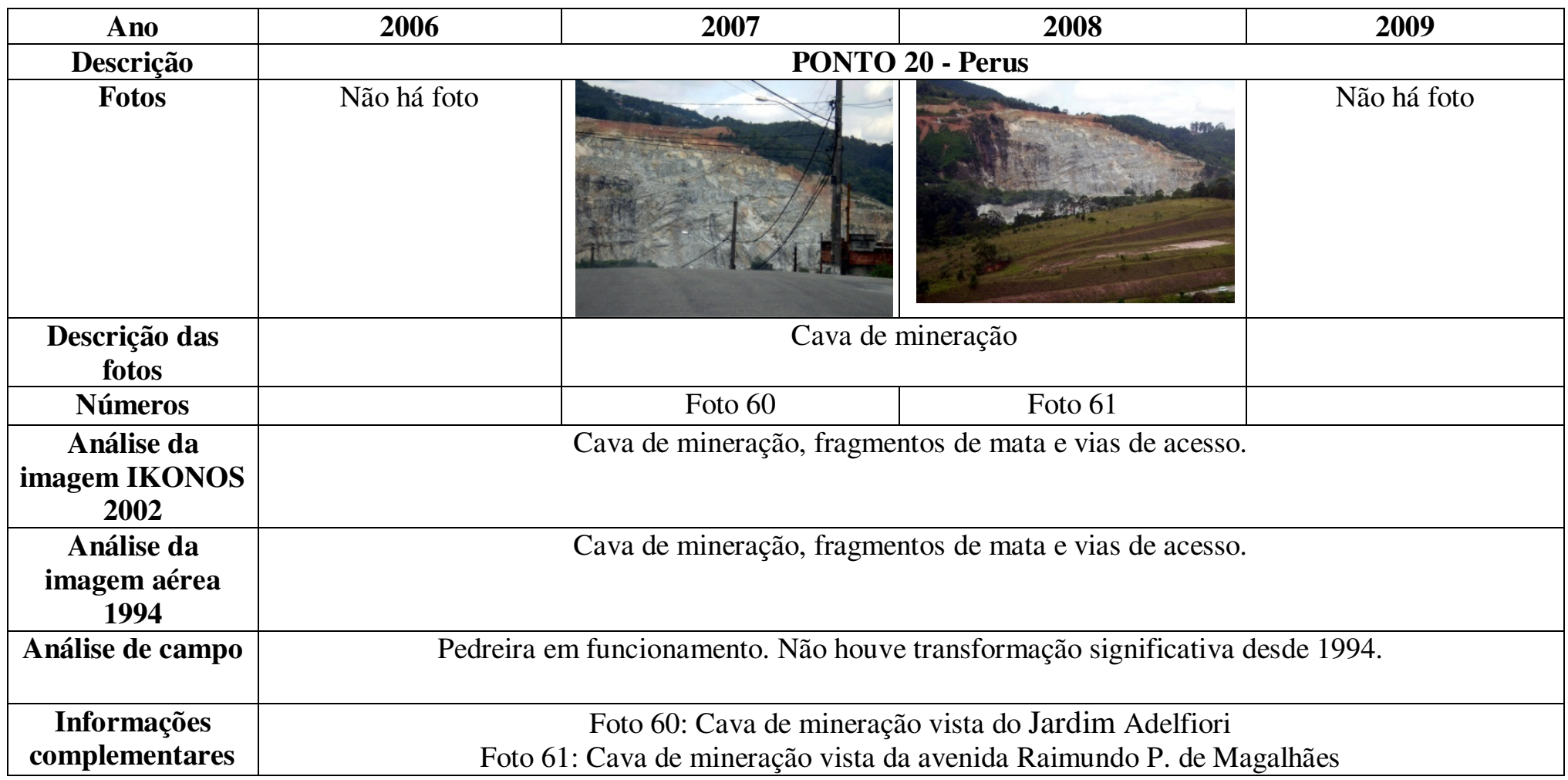




\begin{tabular}{|c|c|c|c|c|}
\hline Ano & 2006 & 2007 & 2008 & 2009 \\
\hline Descrição & \multicolumn{4}{|c|}{ PONTO 23 - Perus } \\
\hline Fotos & Não há foto & Não há foto & Não há foto & \\
\hline Descrição das Fotos & & & & Galpões, casas e árvores \\
\hline Números & & & & Foto 62 \\
\hline Fotos & & Não há foto & Não há foto & \\
\hline Descrição das Fotos & Linha férrea & & & $\begin{array}{l}\text { Linha férrea, córrego, } \\
\text { vila ao fundo }\end{array}$ \\
\hline Números & Foto 63 & & & Foto 64 \\
\hline $\begin{array}{l}\text { Análise da imagem } \\
\text { IKONOS } 2002\end{array}$ & \multicolumn{4}{|c|}{ Galpões (indústrias), linha férrea, solo exposto. } \\
\hline $\begin{array}{l}\text { Análise da imagem } \\
\text { aérea } 1994\end{array}$ & \multicolumn{4}{|c|}{ Galpões (indústrias), linha férrea, solo exposto. } \\
\hline Análise de campo & \multicolumn{4}{|c|}{$\begin{array}{l}\text { Indústrias em funcionamento, ocupação residencial do outro lado da linha férrea (Recanto dos Humildes), } \\
\text { predominância de solo exposto e ruas de terra. Desde } 1994 \text { houve o crescimento da ocupação residencial } \\
\text { precária e galpões industriais. Não houve transformações significativas desde o ano de } 2002 \text { onde } \\
\text { localizam-se os galpões. Na vila Recanto dos Humildes houve a construção de uma escola pública após o } \\
\text { ano de } 2002 \text {. } \\
\text { As fotos foram registradas do ponto onde a linha férrea cruza com o Rodoanel. }\end{array}$} \\
\hline $\begin{array}{c}\text { Informações } \\
\text { complementares }\end{array}$ & \multicolumn{4}{|c|}{$\begin{array}{l}\text { Foto 63: A Ferrovia recebeu inicialmente o nome de Companhia Industrial Estrada de Ferro Perus- } \\
\text { Pirapora, em } 1914 \text { (CIEFP), depois Estrada de Ferro Perus-Pirapora (EFPP). (SIQUEIRA, 2001) }\end{array}$} \\
\hline
\end{tabular}

São Paulo 


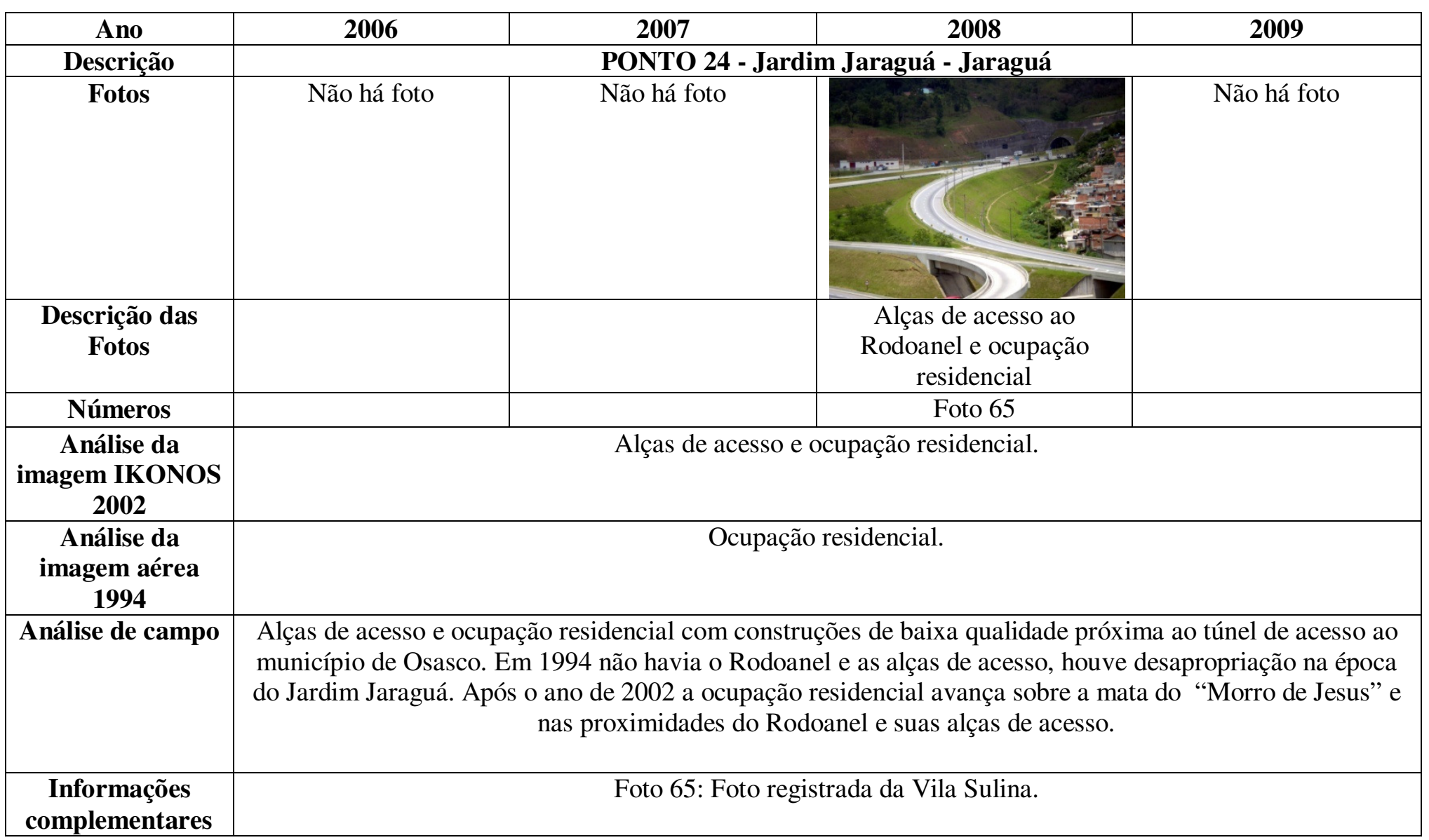




\begin{tabular}{|c|c|c|c|c|}
\hline Ano & 2006 & 2007 & 2008 & 2009 \\
\hline Descrição & \multicolumn{4}{|c|}{ PONTO 25 - Vila Sol Nascente - Perus } \\
\hline Fotos & Não há foto & Não há foto & Não há fo & \\
\hline Descrição das fotos & & & & Lago \\
\hline Números & & & & Foto 66 \\
\hline Fotos & Não há foto & Não há foto & Não há fo & \\
\hline Descrição das fotos & & & & Portão da chácara \\
\hline Números & & & & Foto 67 \\
\hline $\begin{array}{l}\text { Análise da imagem } \\
\text { IKONOS } 2002\end{array}$ & \multicolumn{4}{|c|}{ Casa, lago, árvores. } \\
\hline $\begin{array}{l}\text { Análise da imagem } \\
\text { aérea } 1994\end{array}$ & \multicolumn{4}{|c|}{ Casa, lago, árvores. } \\
\hline Análise de campo & \multicolumn{4}{|c|}{$\begin{array}{l}\text { Casa e lago cercados por árvores, terreno delimitado com cercas. Propriedade particular. Não houve } \\
\text { transformação significativa desde o ano de } 1994 .\end{array}$} \\
\hline $\begin{array}{c}\text { Informações } \\
\text { complementares }\end{array}$ & & & & \\
\hline
\end{tabular}




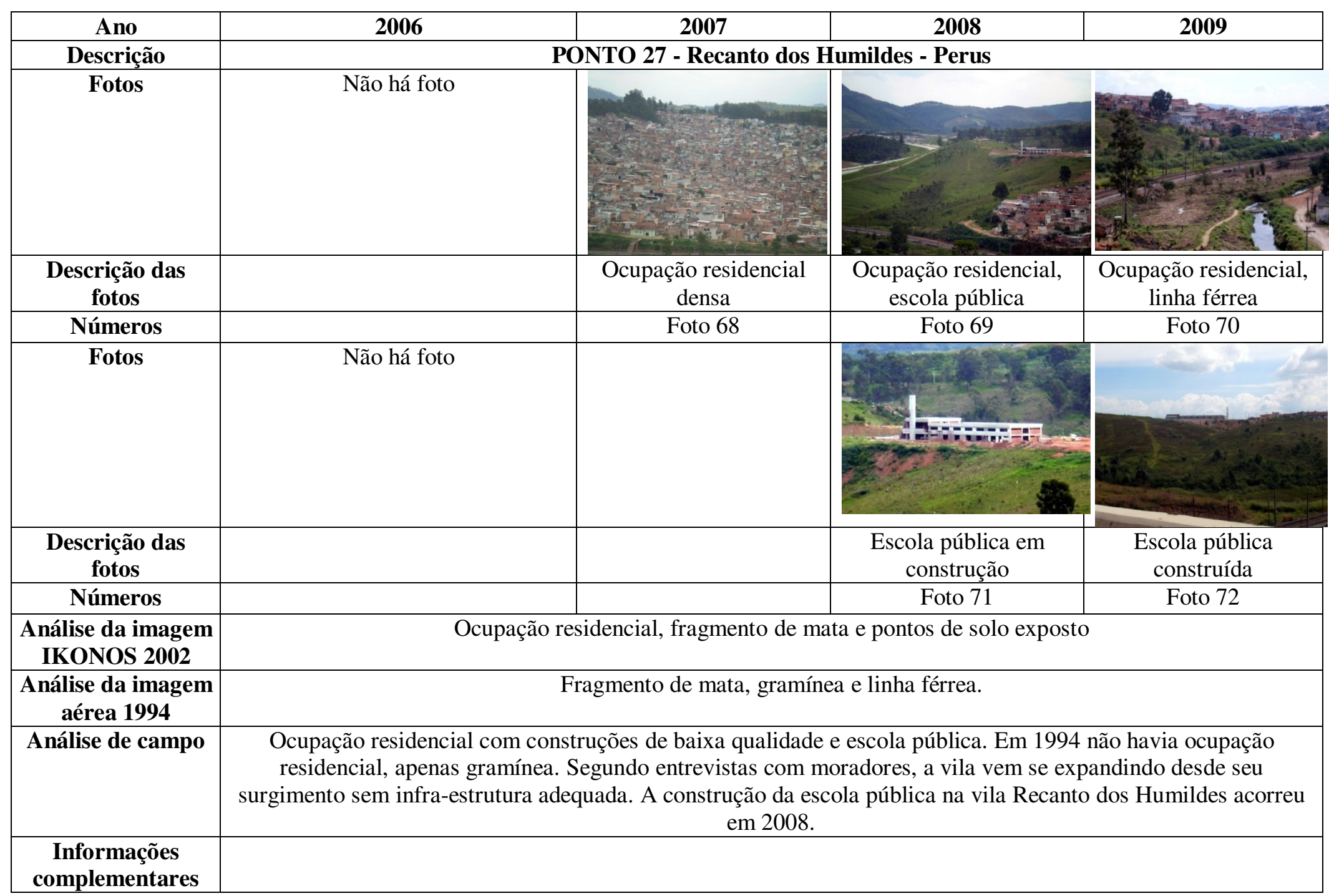




\begin{tabular}{|c|c|c|c|c|}
\hline Ano & 2006 & 2007 & 2008 & 2009 \\
\hline Descrição & \multicolumn{4}{|c|}{ PONTO 28 - Jaraguá } \\
\hline Fotos & Não há foto & Não há foto & 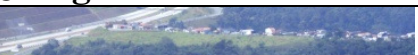 & Não há foto \\
\hline $\begin{array}{l}\text { Descrição das } \\
\text { fotos }\end{array}$ & & & $\begin{array}{l}\text { Rodovia, fragmento de } \\
\text { mata e ocupação } \\
\text { residencial }\end{array}$ & \\
\hline Números & & & Foto 73 & \\
\hline $\begin{array}{c}\text { Análise da } \\
\text { imagem IKONOS } \\
2002 \\
\end{array}$ & \multicolumn{4}{|c|}{ Fragmento de mata e alças de acesso. } \\
\hline $\begin{array}{c}\text { Análise da } \\
\text { imagem aérea } \\
1994\end{array}$ & \multicolumn{4}{|c|}{ Fragmento de mata e solo exposto. } \\
\hline Análise de campo & \multicolumn{4}{|c|}{$\begin{array}{l}\text { Fragmento de mata ao lado da rodovia Bandeirantes e das alças de acesso ao Rodoanel. Não houve } \\
\text { transformação significativa desde o ano } 1994 \text { no fragmento de mata. }\end{array}$} \\
\hline $\begin{array}{c}\text { Informações } \\
\text { complementares }\end{array}$ & \multicolumn{4}{|c|}{ A frente Vila Homero e ao fundo Vila Aurora (Jaraguá) } \\
\hline
\end{tabular}




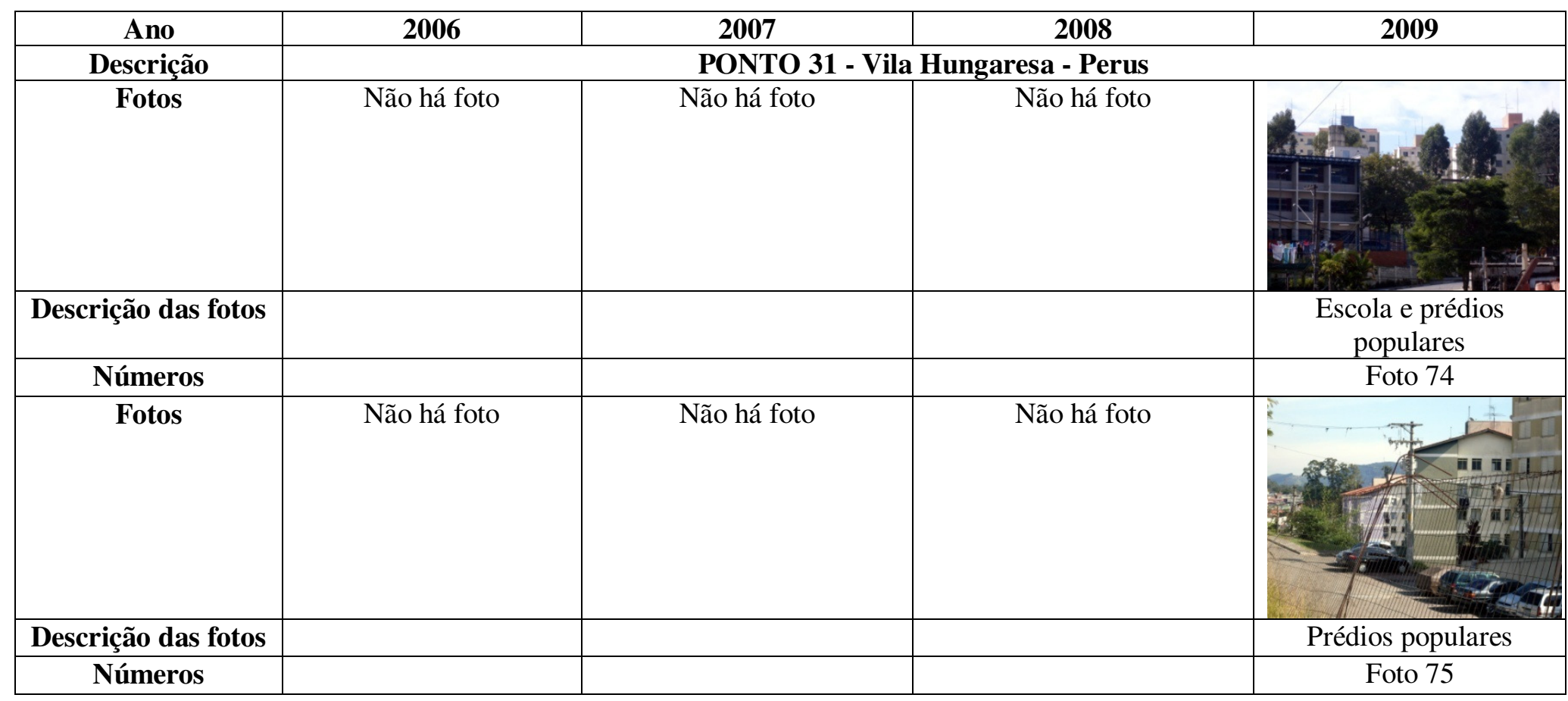




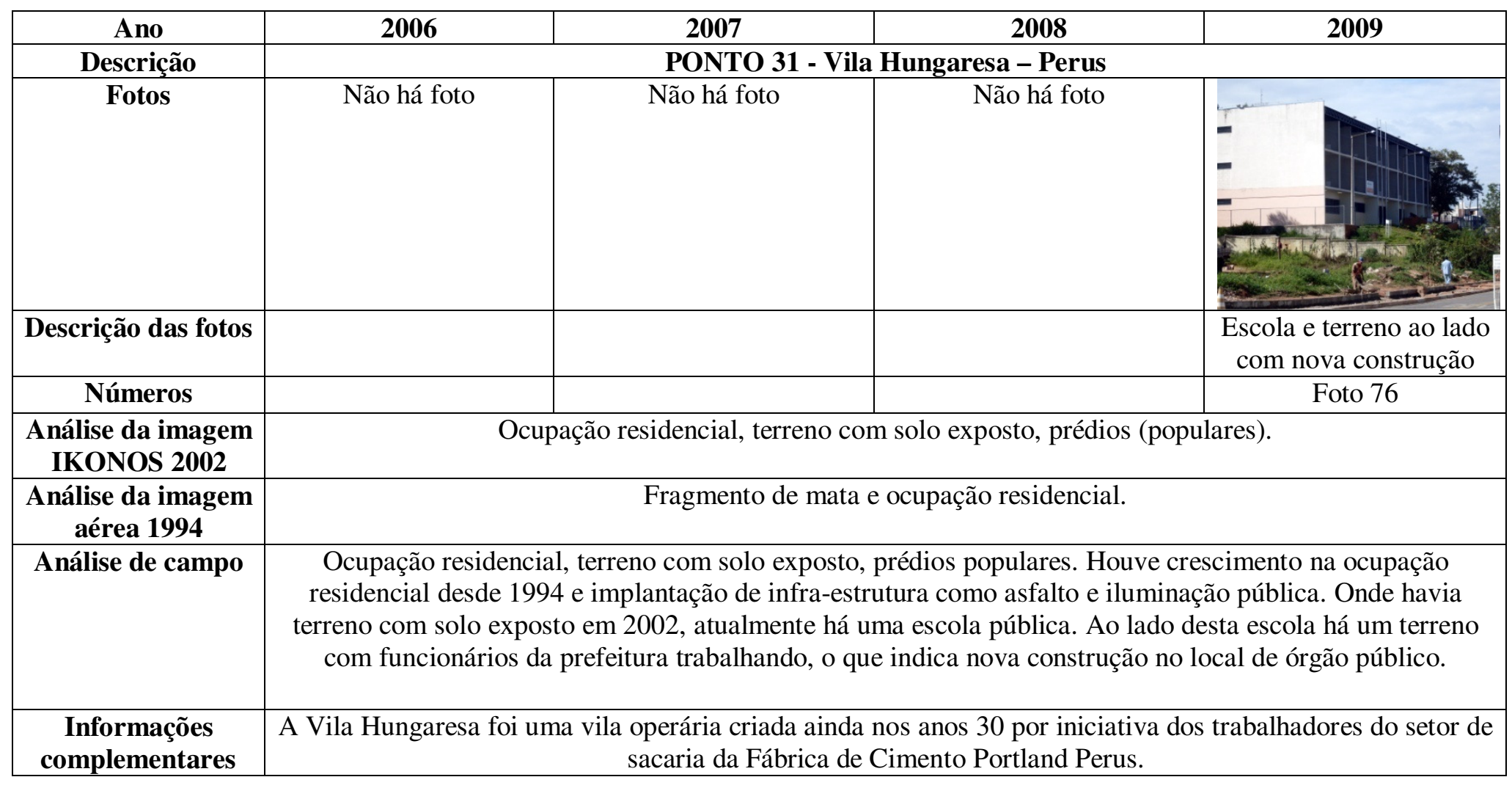




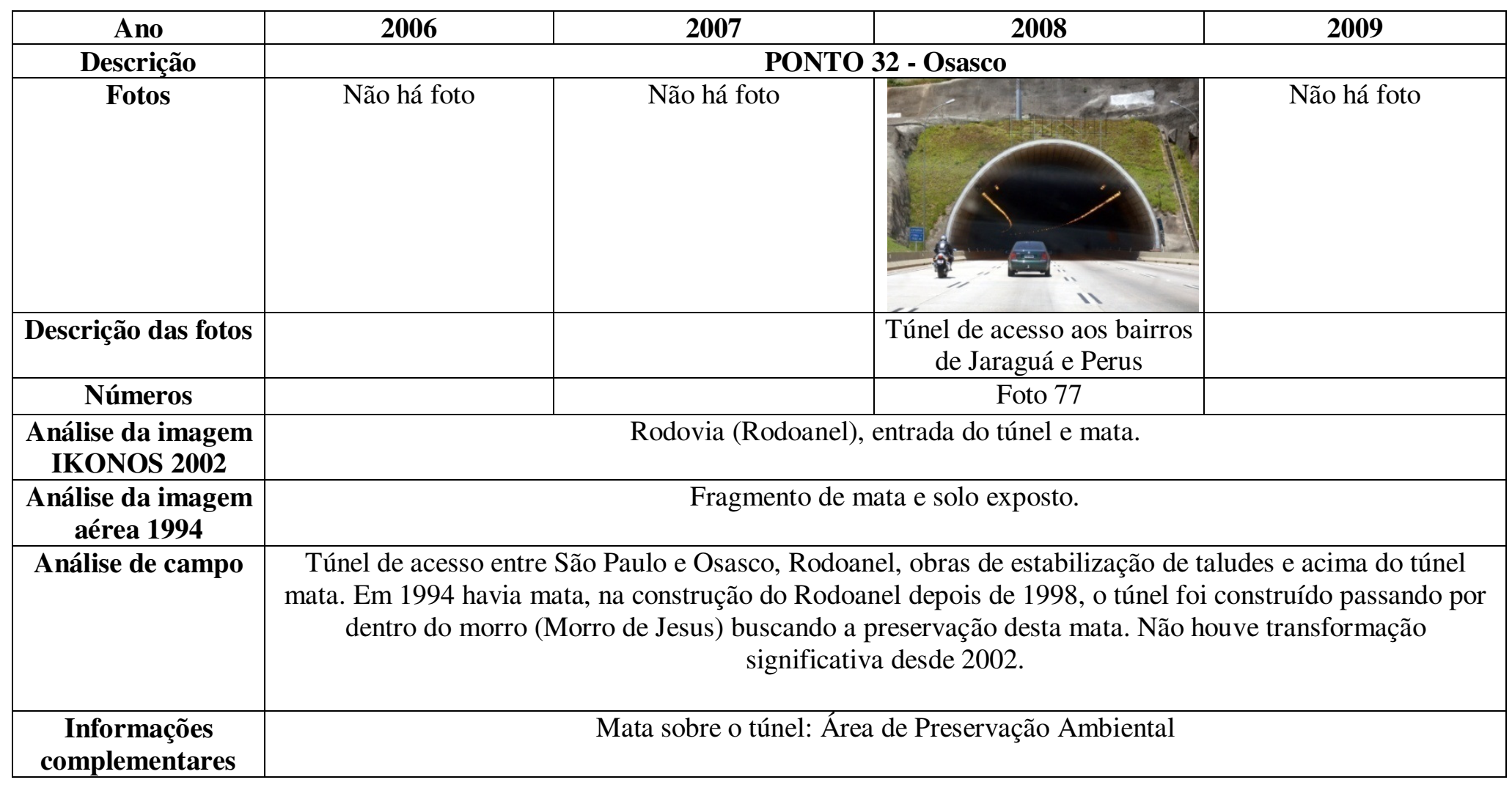




\begin{tabular}{|c|c|c|c|c|}
\hline Ano & 2006 & 2007 & 2008 & 2009 \\
\hline Descrição & \multicolumn{4}{|c|}{ PONTO 33 - Parque do Pico do Jaraguá - Jaraguá } \\
\hline Fotos & Não há foto & Não há fot & & Não há foto \\
\hline Descrição das fotos & & & $\begin{array}{r}\text { Construção, } 1 \\
\text { estacionam }\end{array}$ & \\
\hline Números & & & Foto 78 & \\
\hline $\begin{array}{l}\text { Análise da imagem } \\
\text { IKONOS 2002 }\end{array}$ & \multicolumn{4}{|c|}{ Mata, construção, estacionamento. } \\
\hline $\begin{array}{c}\text { Análise da imagem } \\
\text { aérea } 1994\end{array}$ & \multicolumn{4}{|c|}{ Mata, construção, solo exposto, gramínea. } \\
\hline Análise de campo & \multicolumn{4}{|c|}{$\begin{array}{l}\text { Lanchonete, mata do parque, estacionamento e playground. Não houve transformação significativa desde } \\
1994 \text {, apenas alguns projetos reforma para melhoria do Parque. }\end{array}$} \\
\hline $\begin{array}{c}\text { Informações } \\
\text { complementares }\end{array}$ & \multicolumn{4}{|c|}{ Parque do Pico do Jaraguá: Área de Proteção Ambiental } \\
\hline
\end{tabular}




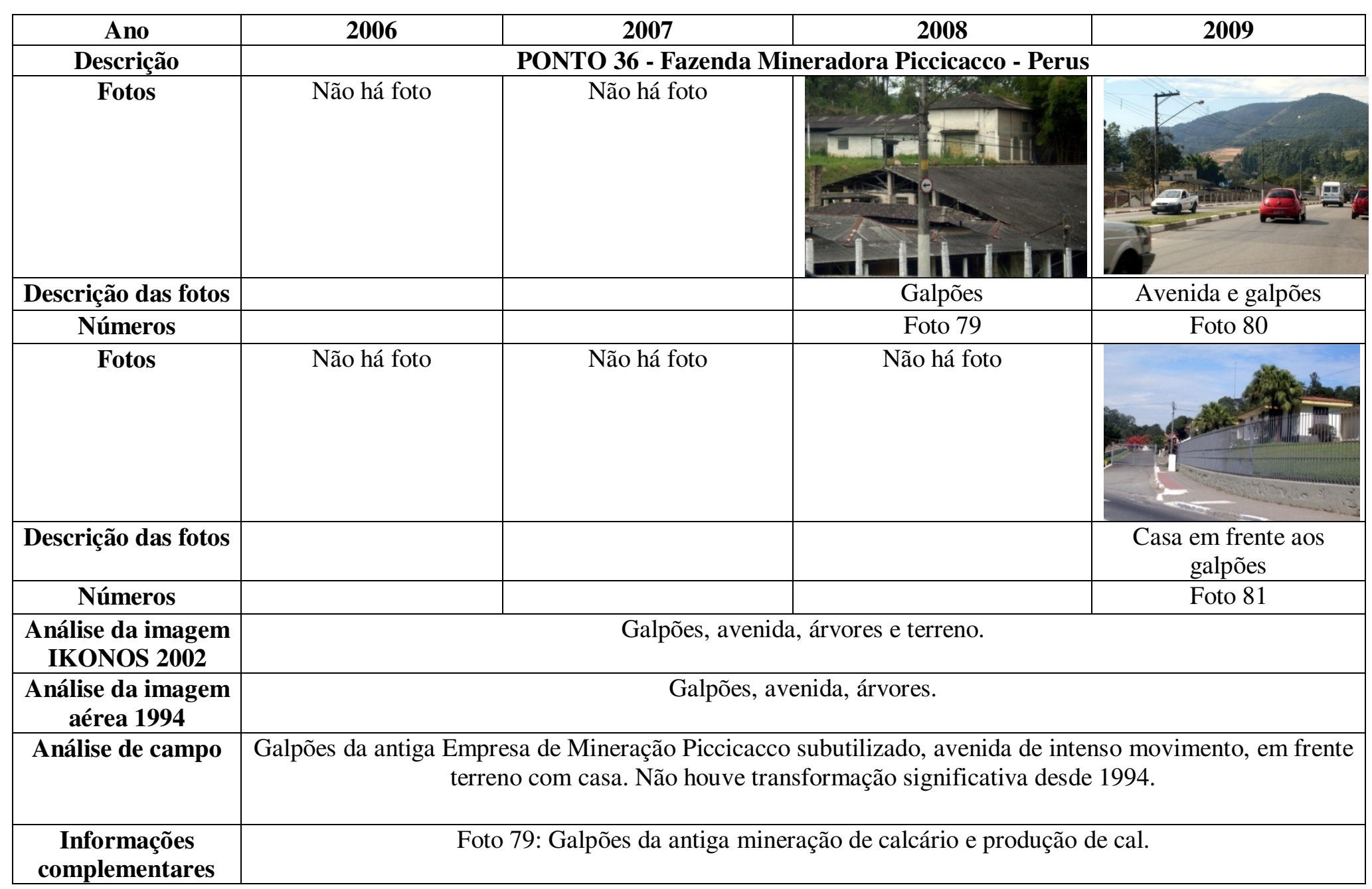




\begin{tabular}{|c|c|c|c|c|}
\hline Ano & 2006 & 2007 & 2008 & 2009 \\
\hline Descrição & \multicolumn{4}{|c|}{ PONTO 37 - Vila Homero - Perus } \\
\hline Fotos & Não há foto & Não há foto & 9 & Não há foto \\
\hline $\begin{array}{l}\text { Descrição das } \\
\text { fotos }\end{array}$ & & & $\begin{array}{l}\text { Via asfaltada, ocupação } \\
\text { residencial, galpão a direita }\end{array}$ & \\
\hline Números & & & Foto 82 & \\
\hline Fotos & Não há foto & Não há foto & & Não há foto \\
\hline $\begin{array}{l}\text { Descrição das } \\
\text { fotos }\end{array}$ & & & $\begin{array}{l}\text { Galpão e ocupação } \\
\text { residencial }\end{array}$ & \\
\hline Números & & & Foto 83 & \\
\hline $\begin{array}{c}\text { Análise da } \\
\text { imagem IKONOS } \\
2002\end{array}$ & \multicolumn{4}{|c|}{ Galpões, marginal (rodovia Bandeirantes) e ocupação residencial. } \\
\hline $\begin{array}{c}\text { Análise da } \\
\text { imagem aérea } \\
1994\end{array}$ & \multicolumn{4}{|c|}{ Galpões, casas, árvores, vias de acesso. } \\
\hline Análise de campo & \multicolumn{4}{|c|}{$\begin{array}{c}\text { Ocupação residencial densa com construções de baixa qualidade, rua asfaltada, iluminação pública, galpões } \\
\text { industriais. Novas casas e galpões foram construídos desde 1994, especialmente na marginal da rodovia } \\
\text { Bandeirantes. }\end{array}$} \\
\hline $\begin{array}{c}\text { Informações } \\
\text { complementares }\end{array}$ & & & & \\
\hline
\end{tabular}




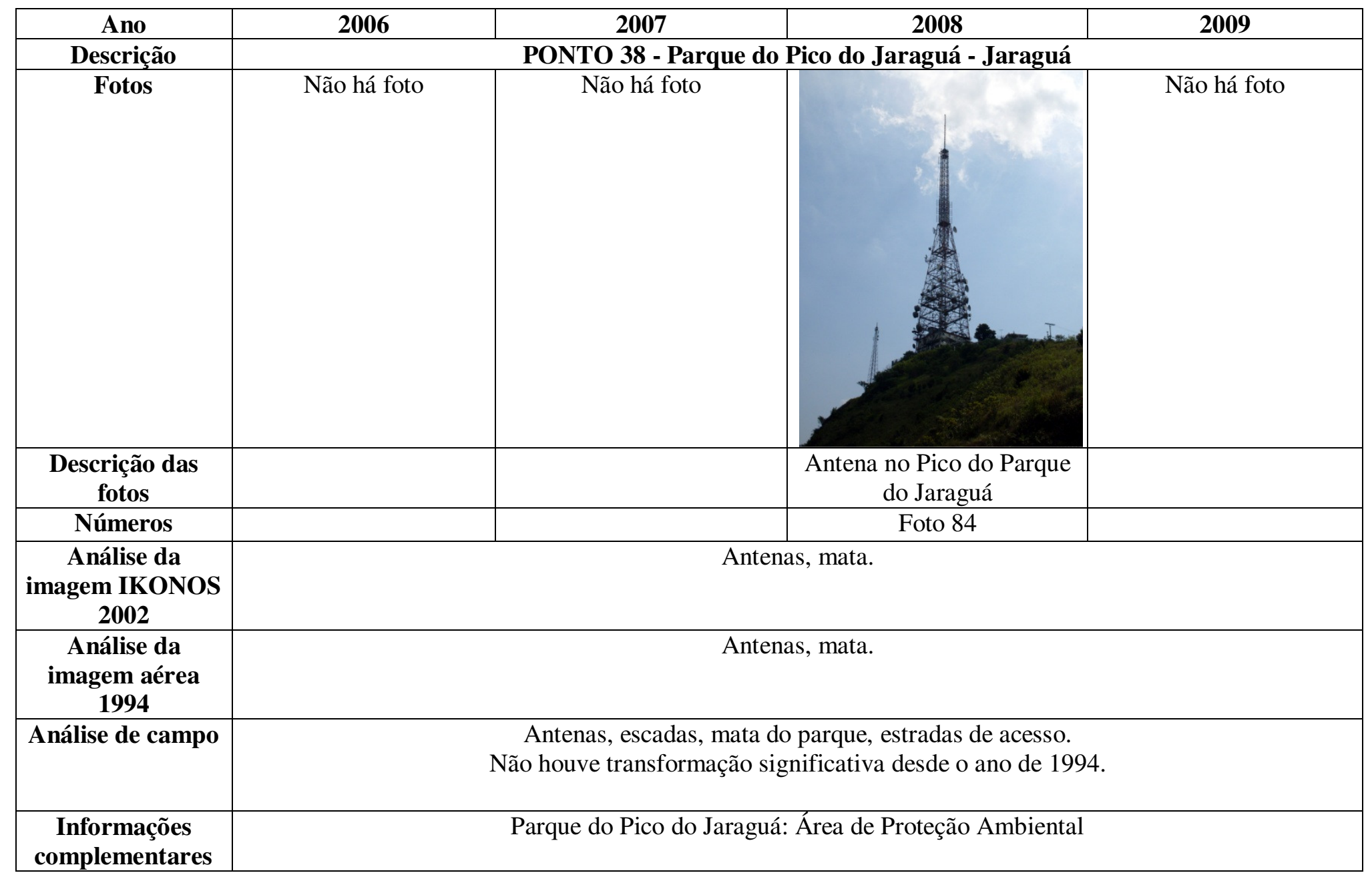




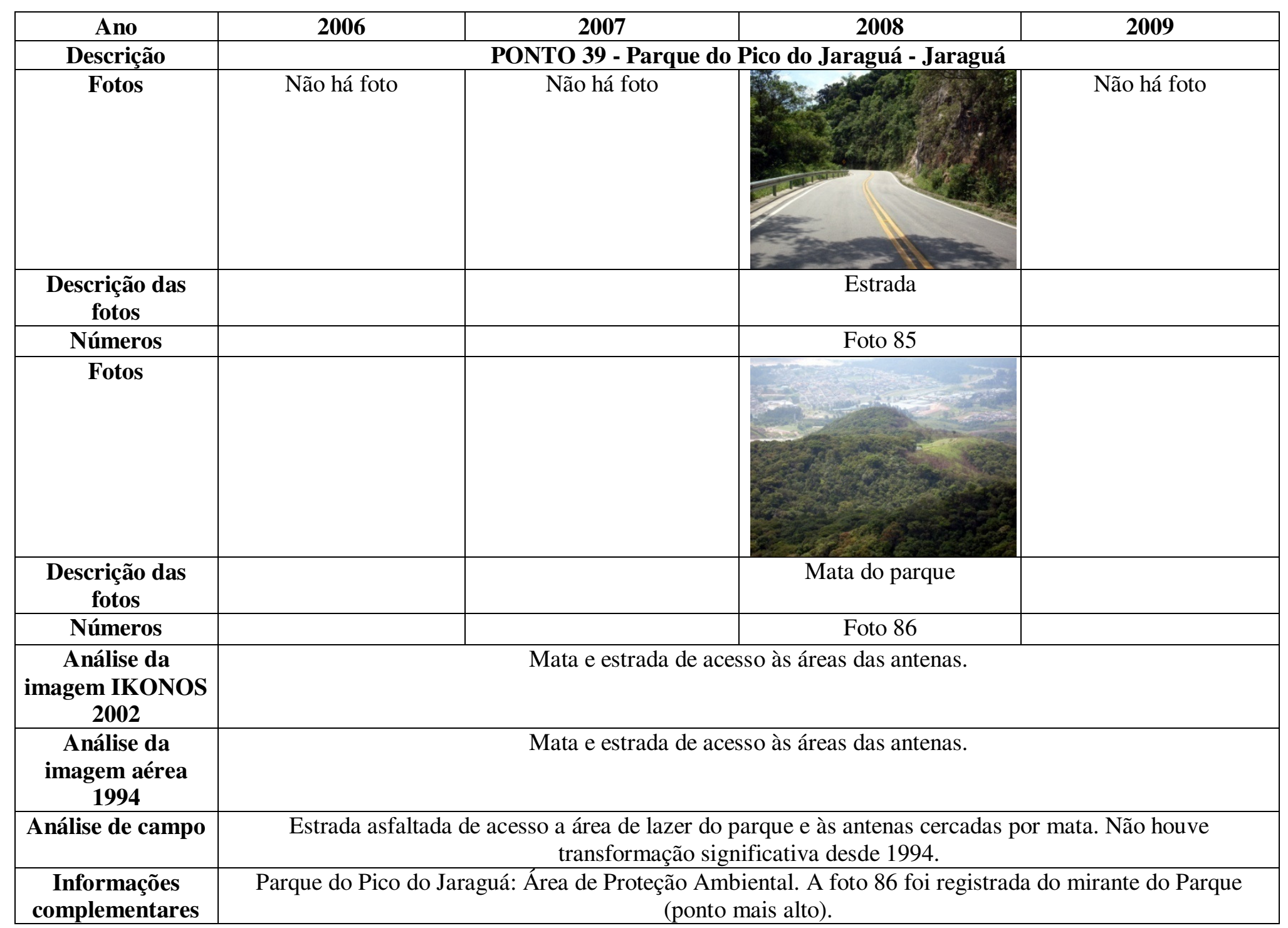




\begin{tabular}{|c|c|c|c|c|}
\hline Ano & 2006 & 2007 & 2008 & 2009 \\
\hline Descrição & \multicolumn{4}{|c|}{ PONTO 41 - Jardim Ipanema - Perus } \\
\hline Fotos & Não há foto & Não há foto & & Não há foto \\
\hline $\begin{array}{c}\text { Descrição das } \\
\text { fotos }\end{array}$ & & & $\begin{array}{r}\text { Ocupação resi } \\
\text { rodovi }\end{array}$ & \\
\hline Números & & & Foto 8 & \\
\hline $\begin{array}{c}\text { Análise da } \\
\text { imagem IKONOS } \\
2002\end{array}$ & \multicolumn{4}{|c|}{ Rodovia (Bandeirantes), ocupação residencial } \\
\hline $\begin{array}{c}\text { Análise da } \\
\text { imagem aérea } \\
1994\end{array}$ & \multicolumn{4}{|c|}{ Solo exposto, fragmento de mata, rodovia (Bandeirantes), construções. } \\
\hline Análise de campo & \multicolumn{4}{|c|}{$\begin{array}{l}\text { Rodovia Bandeirantes e ocupação residencial com construçães de baixa qualidade em terreno íngreme em } \\
\text { meio a fragmento de mata. Não havia ocupação residencial em 1994. Não houve transformação significativa } \\
\text { desde } 2002 .\end{array}$} \\
\hline $\begin{array}{c}\text { Informações } \\
\text { complementares }\end{array}$ & \multicolumn{4}{|c|}{ A foto 87 foi registrada da vila em frente, Vila Homero. } \\
\hline
\end{tabular}









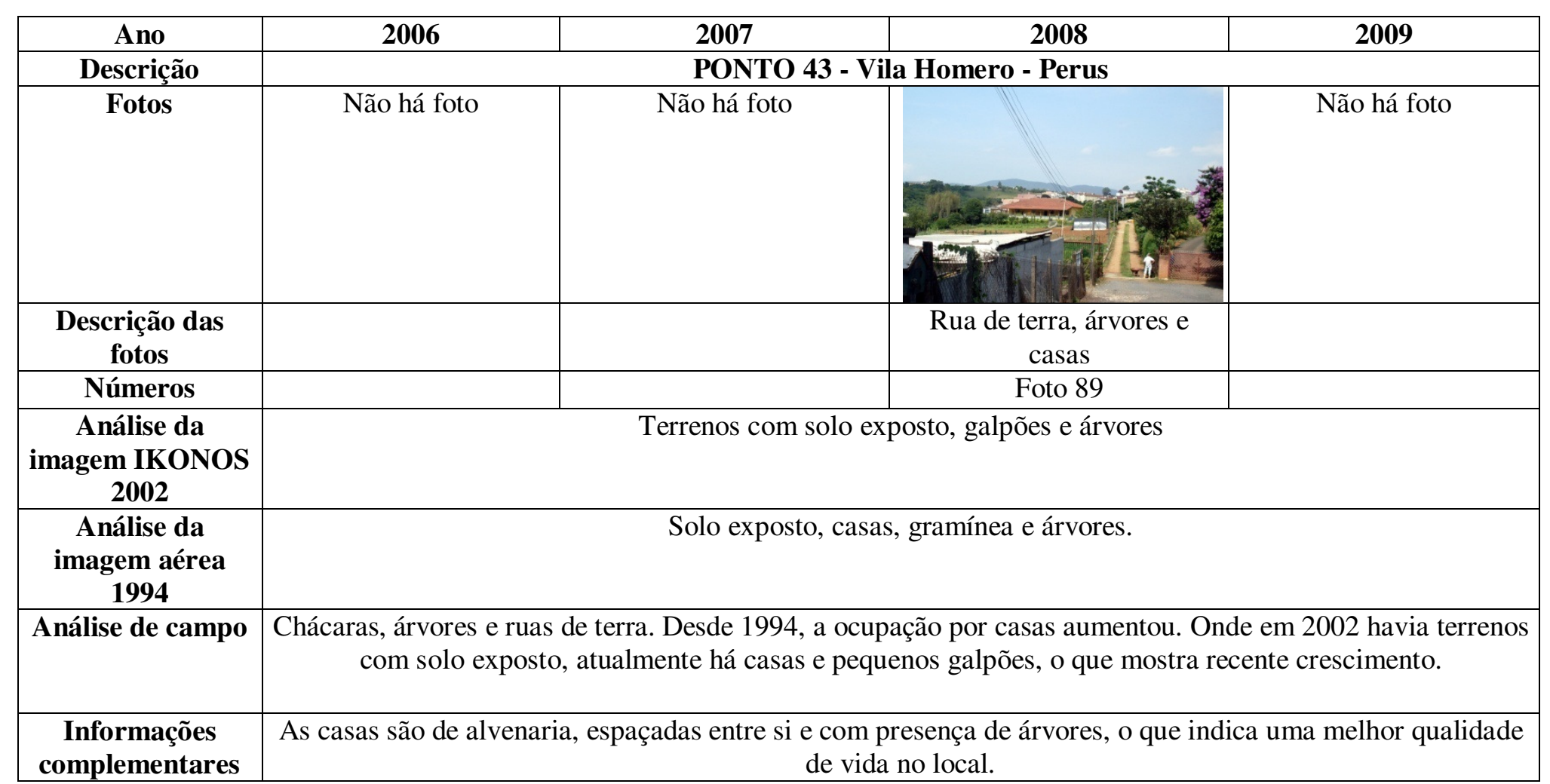




\begin{tabular}{|c|c|c|c|c|}
\hline Ano & 2006 & 2007 & 2008 & 2009 \\
\hline Descrição & \multicolumn{4}{|c|}{ PONTO 44 - Vila Aurora - Jaraguá } \\
\hline Fotos & & Não há foto & & Não há foto \\
\hline $\begin{array}{l}\text { Descrição das } \\
\text { fotos }\end{array}$ & $\begin{array}{c}\text { Ocupação residencial } \\
\text { densa vista da rodovia } \\
\text { Bandeirantes }\end{array}$ & & Ocupação residencial densa & \\
\hline Números & Foto 90 & & Foto 91 & \\
\hline $\begin{array}{l}\text { Análise da } \\
\text { imagem IKONOS } \\
2002\end{array}$ & \multicolumn{4}{|c|}{ Ocupação residencial densa em terrenos íngremes. } \\
\hline $\begin{array}{l}\text { Análise da } \\
\text { imagem aérea } \\
1994\end{array}$ & \multicolumn{4}{|c|}{ Ocupação residencial densa em terrenos íngremes. } \\
\hline Análise de campo & \multicolumn{4}{|c|}{$\begin{array}{c}\text { Ocupação residencial densa em terrenos íngremes, próxima ao Rodoanel, com vias de acesso formais. Em } \\
1994 \text { houve desapropriação para construção de alças de acesso ao Rodoanel. A vila encontra-se em } \\
\text { crescimento sem infra-estrutura adequada para a demanda da vila. }\end{array}$} \\
\hline $\begin{array}{c}\text { Informações } \\
\text { complementares }\end{array}$ & \multicolumn{4}{|c|}{ Foto: Vila Aurora vista da rodovia Bandeirantes } \\
\hline
\end{tabular}




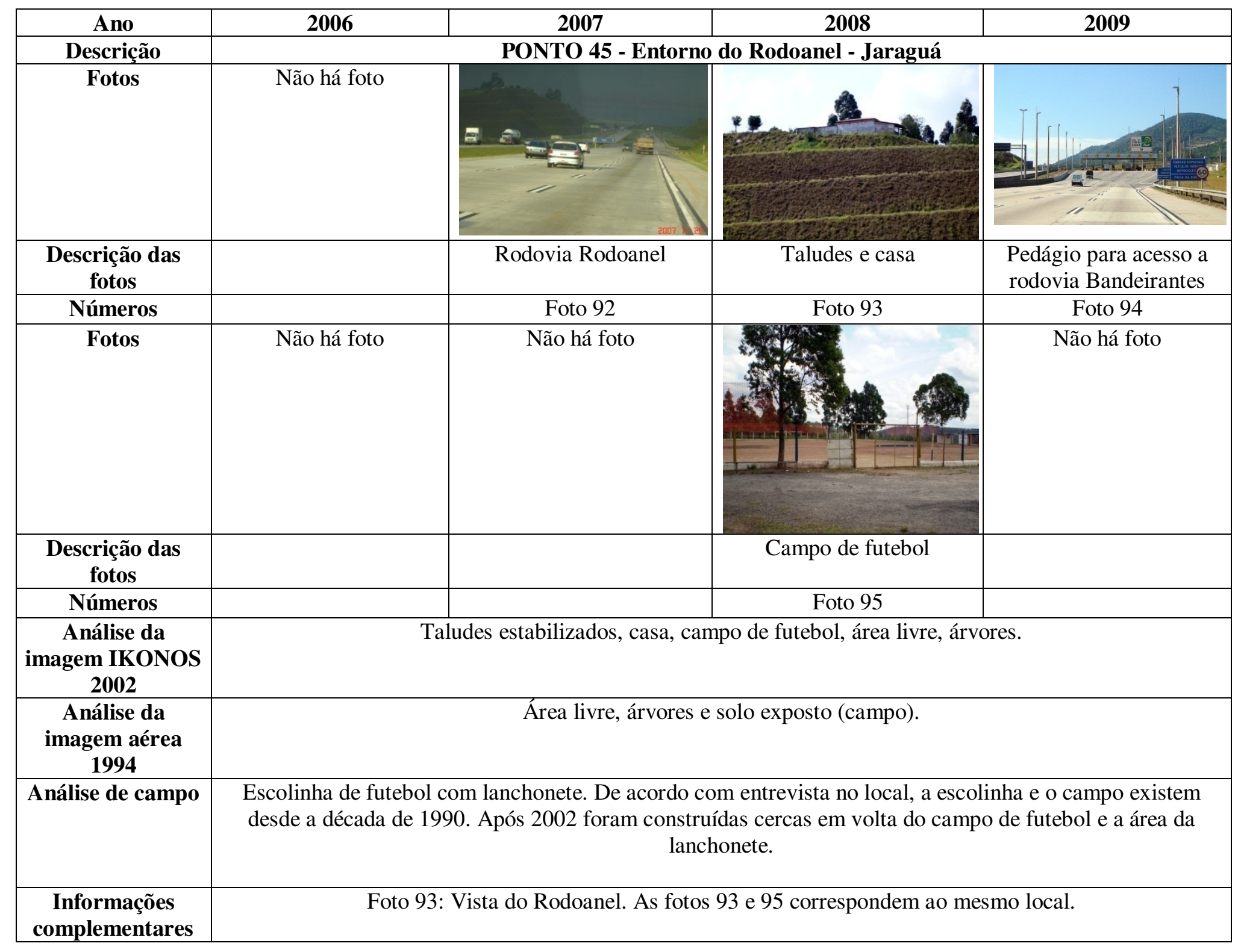

São Paulo 


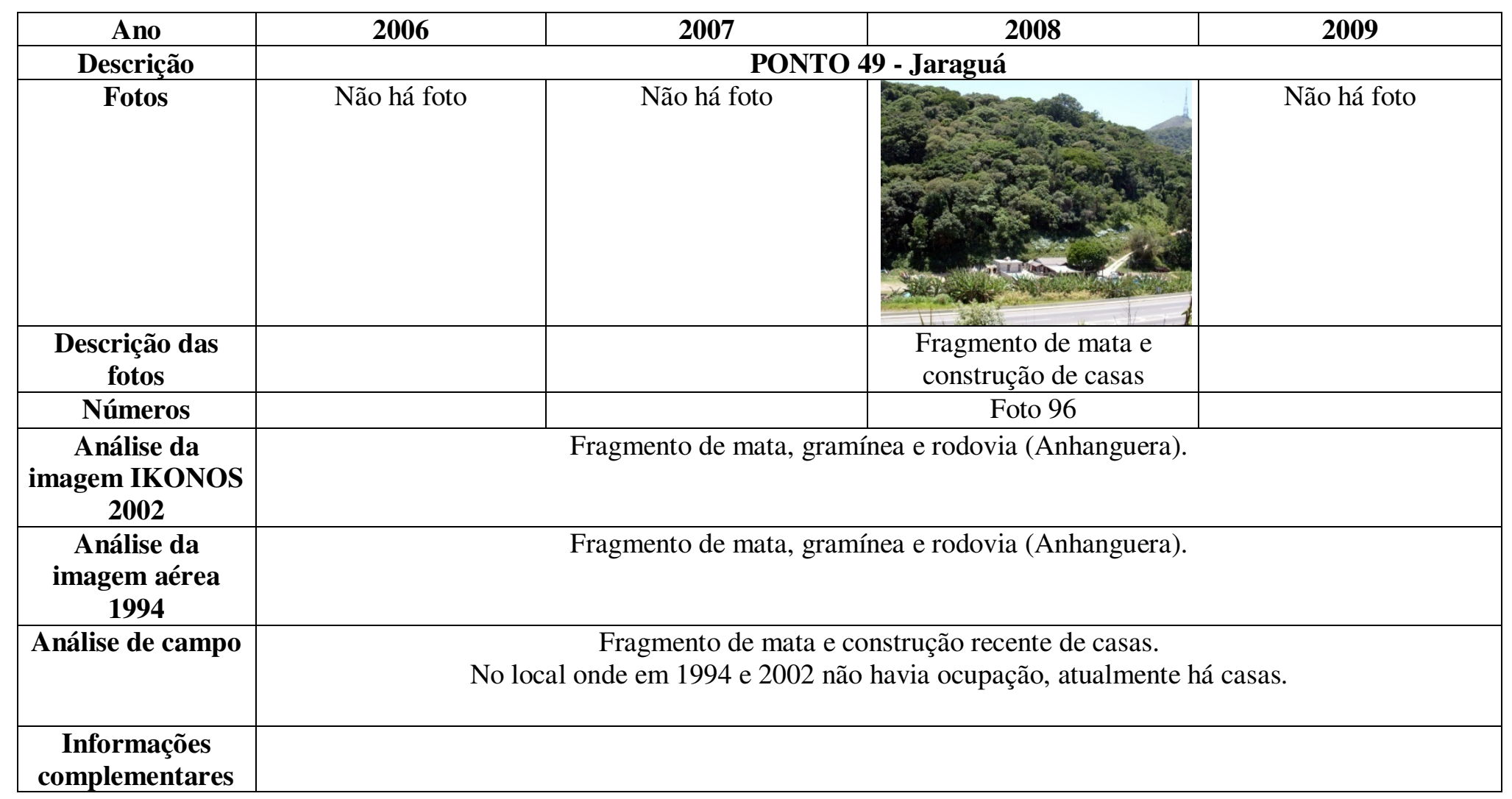




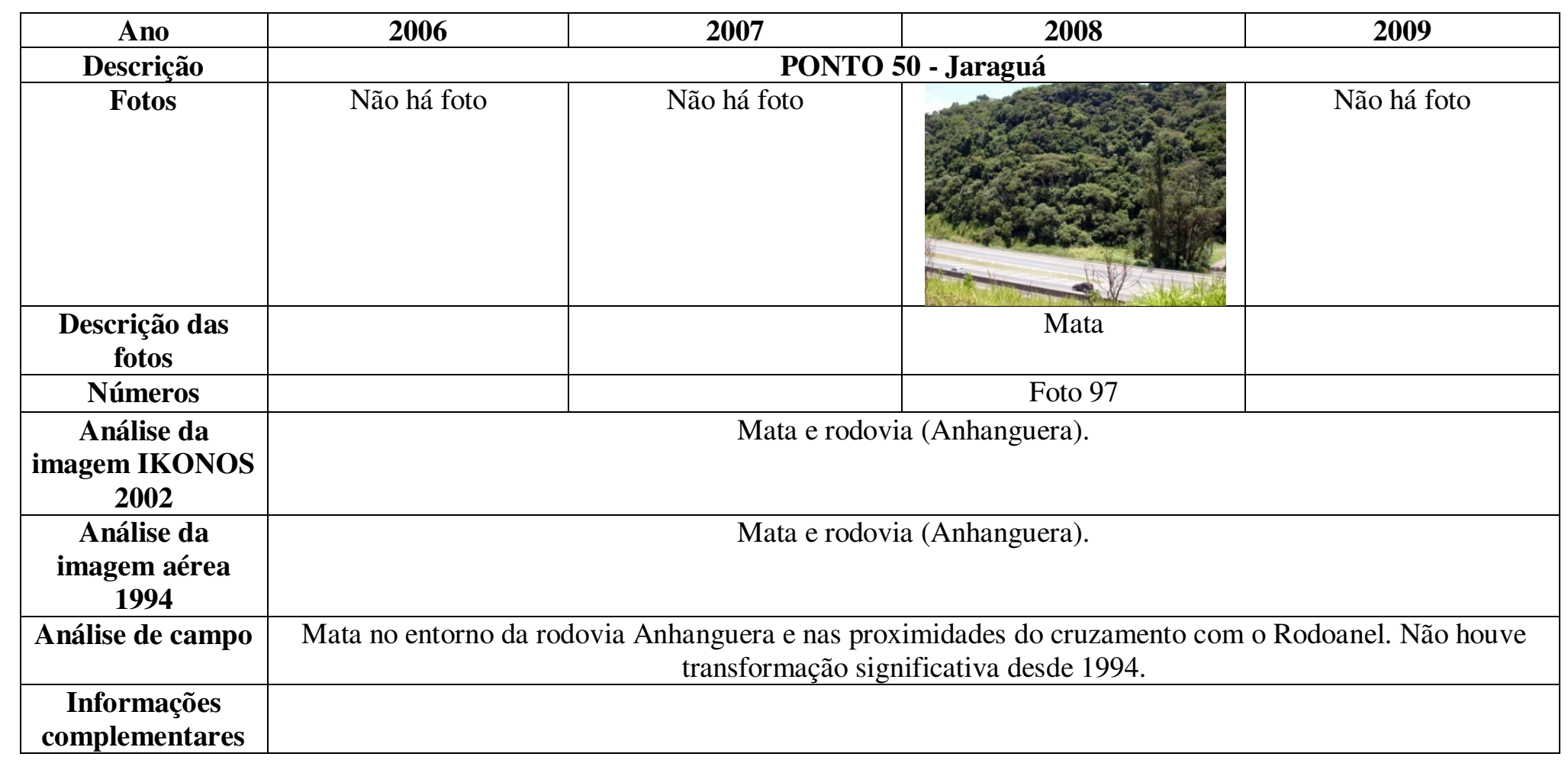




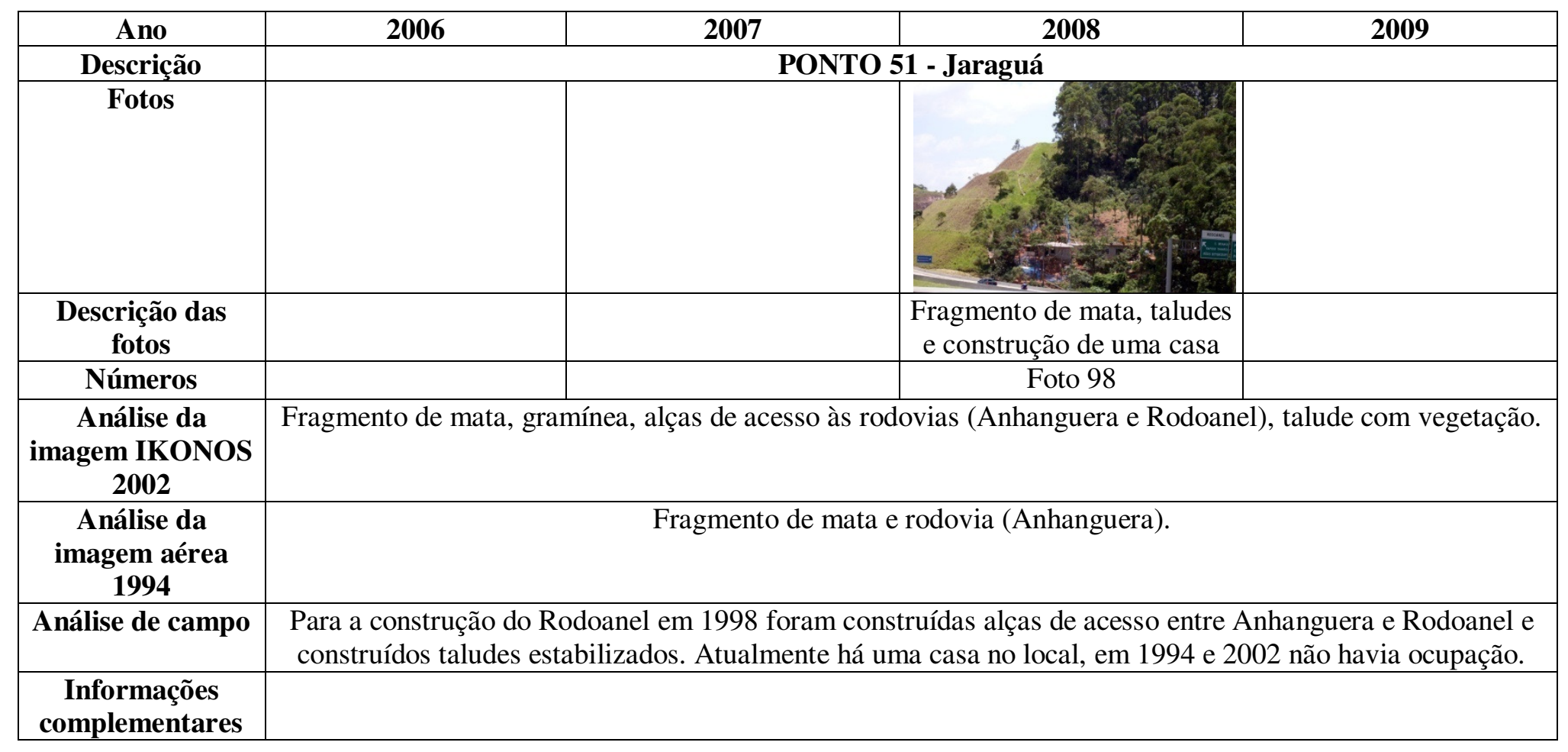




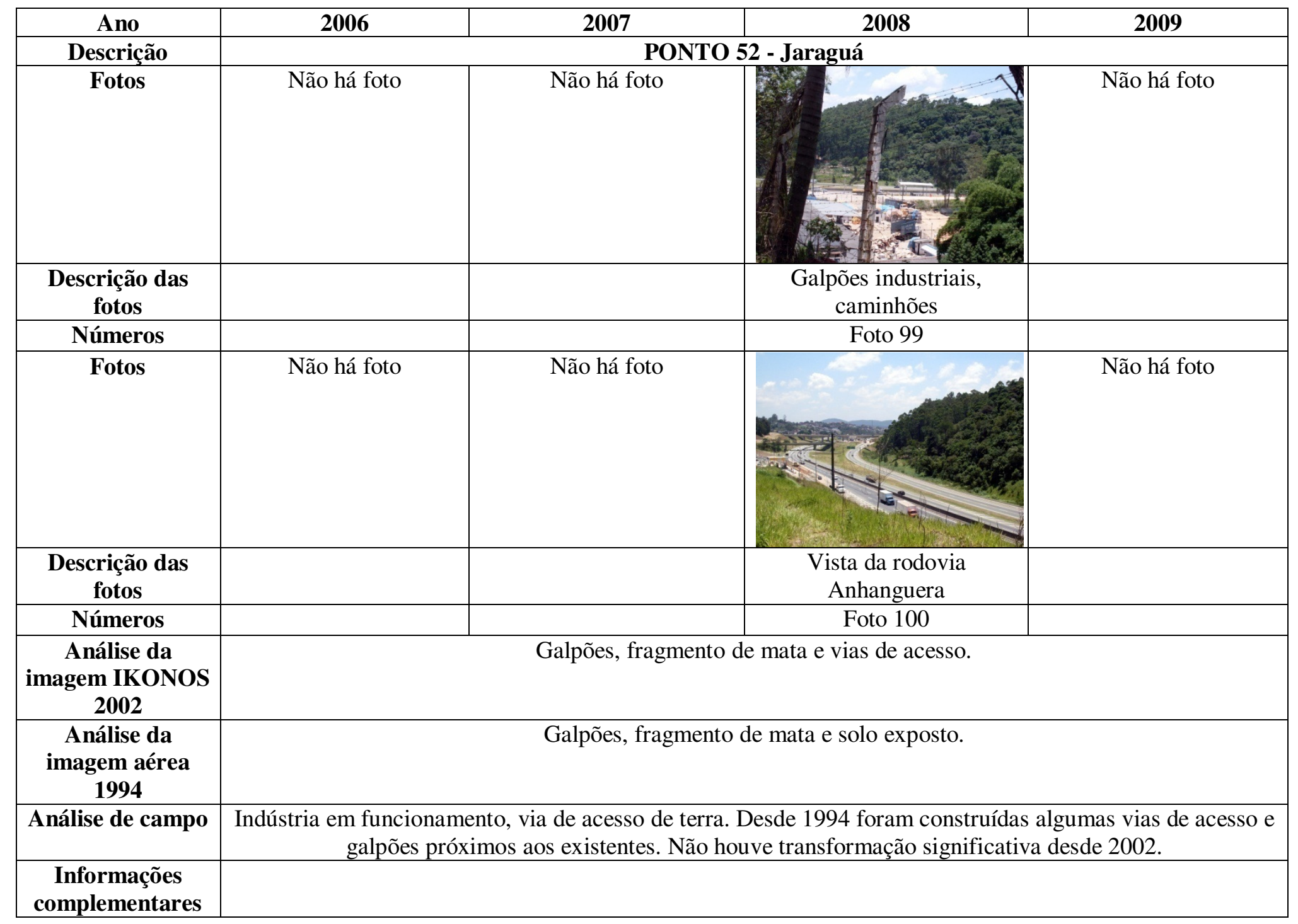




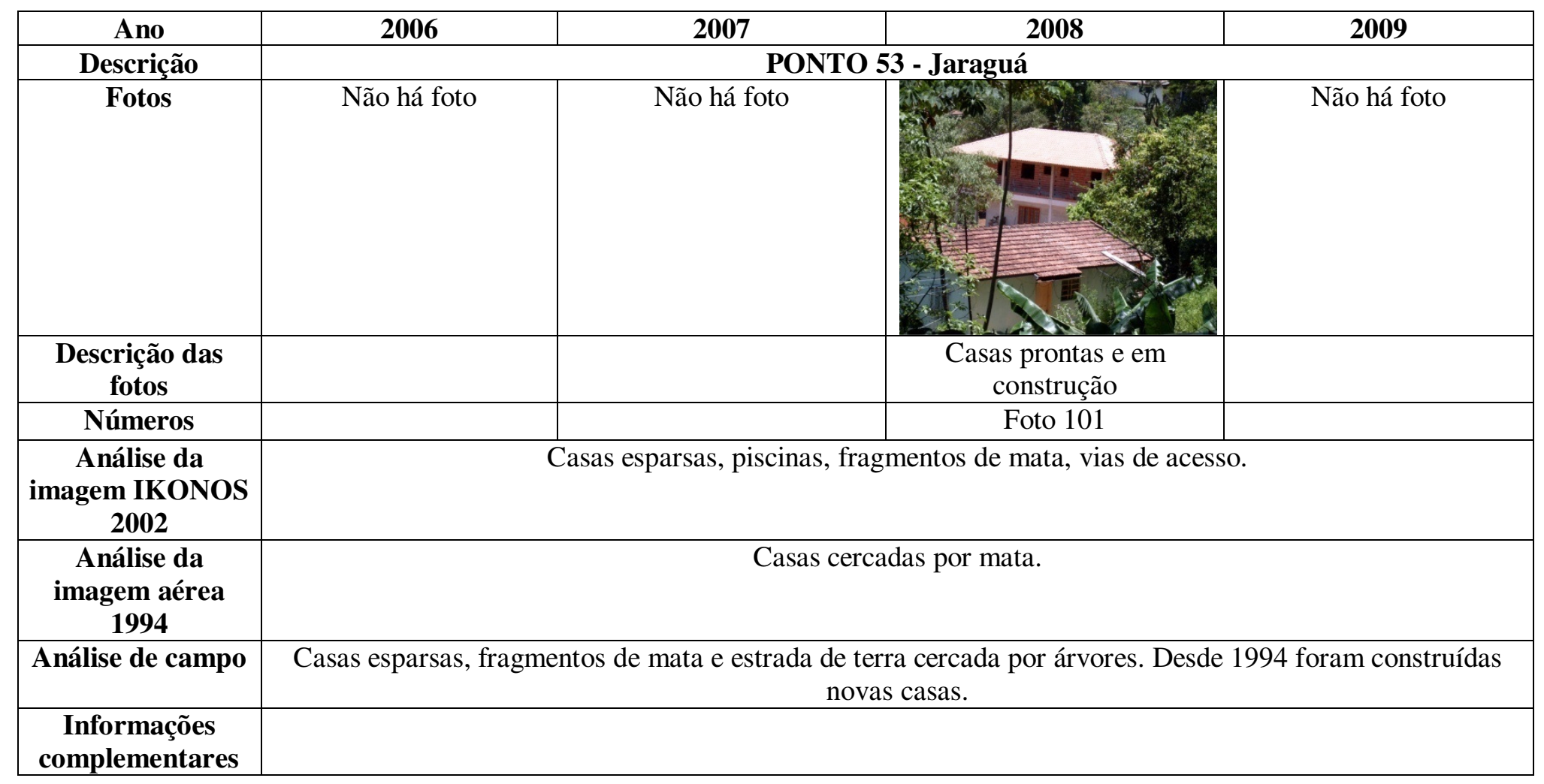




\begin{tabular}{|c|c|c|c|c|}
\hline Ano & 2006 & 2007 & 2008 & 2009 \\
\hline Descrição & \multicolumn{4}{|c|}{ PONTO 54 - Jaraguá } \\
\hline Fotos & Não há foto & Não há foto & & Não há foto \\
\hline $\begin{array}{l}\text { Descrição das } \\
\text { fotos }\end{array}$ & & & $\begin{array}{r}\text { Estrada de terra } \\
\text { por árvor }\end{array}$ & \\
\hline Números & & & Foto 10 & \\
\hline $\begin{array}{c}\text { Análise da } \\
\text { imagem IKONOS } \\
2002\end{array}$ & \multicolumn{4}{|c|}{ Fragmento de mata e estrada. } \\
\hline $\begin{array}{c}\text { Análise da } \\
\text { imagem aérea } \\
1994\end{array}$ & \multicolumn{4}{|c|}{ Fragmento de mata e estrada. } \\
\hline Análise de campo & \multicolumn{4}{|c|}{$\begin{array}{c}\text { Estrada de terra cercada por mata, algumas casas no entorno. Desde } 1994 \text { foram construídas novas casas e } \\
\text { abertas mais vias de acesso. }\end{array}$} \\
\hline $\begin{array}{c}\text { Informações } \\
\text { complementares }\end{array}$ & \multicolumn{4}{|c|}{ Foto 102: Estrada do café } \\
\hline
\end{tabular}




\begin{tabular}{|c|c|c|c|c|}
\hline Ano & 2006 & 2007 & 2008 & 2009 \\
\hline Descrição & \multicolumn{4}{|c|}{$\begin{array}{l}\text { PONTO } 56 \text { - Jaraguá } \\
\end{array}$} \\
\hline Fotos & Não há foto & Não há foto & & Não há foto \\
\hline $\begin{array}{l}\text { Descrição das } \\
\text { fotos }\end{array}$ & & & Fragmento de mata, casas & \\
\hline Números & & & Foto 103 & \\
\hline $\begin{array}{c}\text { Análise da } \\
\text { imagem IKONOS } \\
2002\end{array}$ & \multicolumn{4}{|c|}{ Fragmento de mata e casas. } \\
\hline $\begin{array}{c}\text { Análise da } \\
\text { imagem aérea } \\
1994\end{array}$ & \multicolumn{4}{|c|}{ Gramínea e fragmento de mata. } \\
\hline Análise de campo & \multicolumn{4}{|c|}{$\begin{array}{l}\text { Mata e casas esparsas de alto padrão. Após } 1994 \text { foram construídas casas de alta qualidade em meio ao } \\
\text { fragmento de mata. }\end{array}$} \\
\hline $\begin{array}{c}\text { Informações } \\
\text { complementares }\end{array}$ & & & & \\
\hline
\end{tabular}




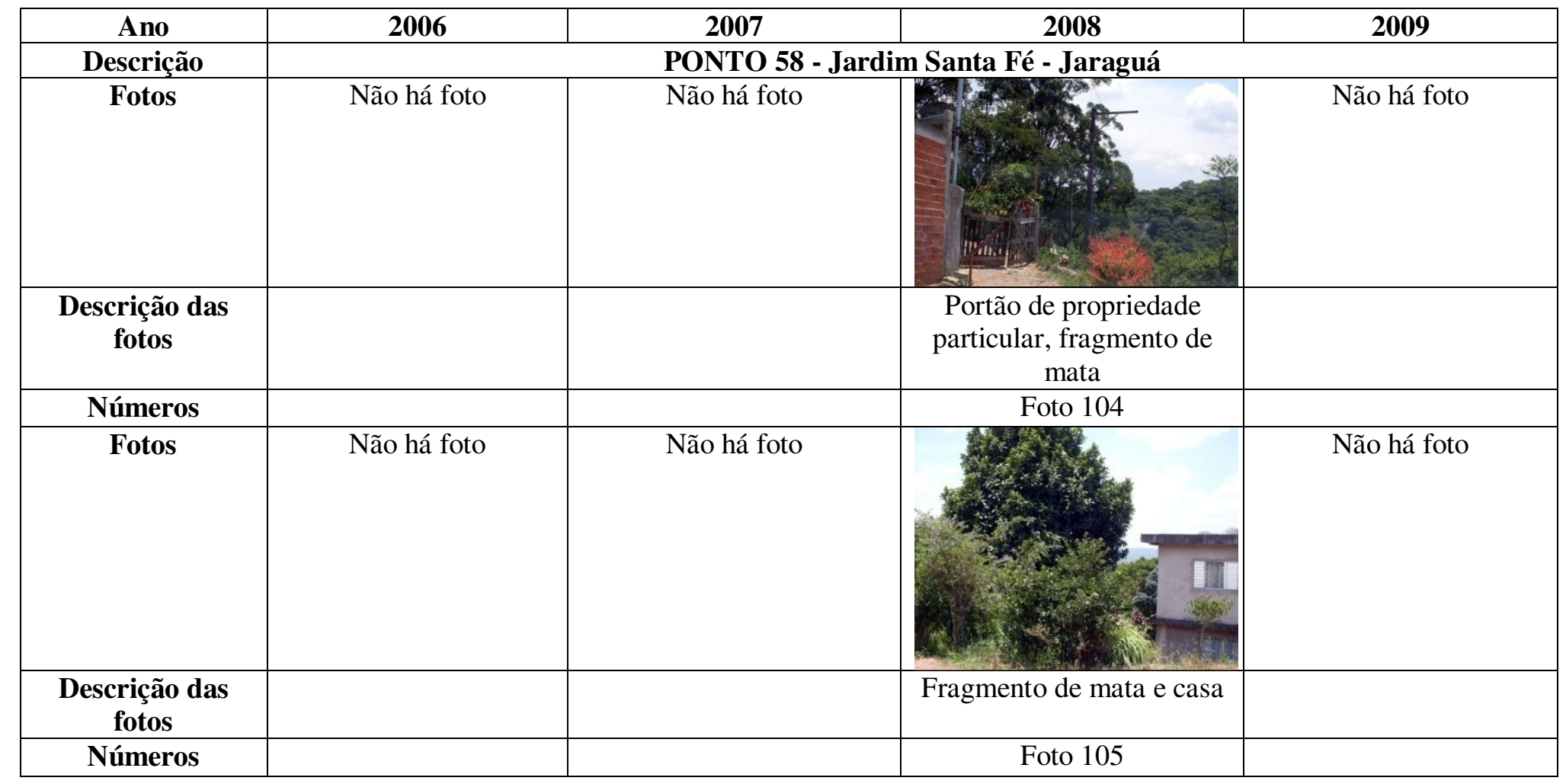




\begin{tabular}{|c|c|c|c|c|}
\hline Ano & 2006 & 2007 & 2008 & 2009 \\
\hline Descrição & \multicolumn{4}{|c|}{ PONTO 58 - Jardim Santa Fé - Jaraguá } \\
\hline Fotos & Não há foto & Não há foto & & Não há foto \\
\hline $\begin{array}{l}\text { Descrição das } \\
\text { fotos }\end{array}$ & & & $\begin{array}{l}\text { Solo exposto e fragmento } \\
\text { de mata }\end{array}$ & \\
\hline Números & & & Foto 106 & \\
\hline $\begin{array}{c}\text { Análise da } \\
\text { imagem IKONOS } \\
2002 \\
\end{array}$ & \multicolumn{4}{|c|}{ Fragmento de mata, solo exposto e casas. } \\
\hline $\begin{array}{c}\text { Análise da } \\
\text { imagem aérea } \\
1994\end{array}$ & \multicolumn{4}{|c|}{ Fragmento de mata, solo exposto. } \\
\hline Análise de campo & \multicolumn{4}{|c|}{$\begin{array}{l}\text { Mata, terreno com solo exposto, casas. Onde inicia a mata não há mais ocupação. Atualmente há casa onde } \\
\text { em } 1994 \text { e } 2002 \text { havia solo exposto, mas não há infra-estrutura adequada no local. }\end{array}$} \\
\hline $\begin{array}{c}\text { Informações } \\
\text { complementares }\end{array}$ & & & & \\
\hline
\end{tabular}




\begin{tabular}{|c|c|c|c|c|}
\hline Ano & Anterior a 2006 & 2007 & 2008 & 2009 \\
\hline Descrição & \multicolumn{4}{|c|}{ PONTO 59 - Túnel de acesso a Osasco - Jaraguá } \\
\hline Fotos & & & & Não há foto \\
\hline $\begin{array}{l}\text { Descrição das } \\
\text { fotos }\end{array}$ & $\begin{array}{l}\text { Mata sobre o túnel, } \\
\text { Rodoanel }\end{array}$ & $\begin{array}{l}\text { Mata sobre o túnel, } \\
\text { Rodoanel, ocupação } \\
\text { residencial densa a direita }\end{array}$ & $\begin{array}{l}\text { Mata sobre o túnel, } \\
\text { Rodoanel, ocupação } \\
\text { residencial densa a direita }\end{array}$ & \\
\hline Números & $\begin{array}{l}\text { Foto } 107 \\
\text { Fonte: André Bonacin }{ }^{26}\end{array}$ & Foto 108 & Foto 109 & \\
\hline $\begin{array}{l}\text { Análise da } \\
\text { imagem IKONOS } \\
2002 \\
\end{array}$ & \multicolumn{4}{|c|}{$\begin{array}{l}\text { Rodovia (Rodoanel), alças de acesso para a outra rodovia (Anhanguera) e mata sobre o túnel } \\
\text { (Morro de Jesus). }\end{array}$} \\
\hline $\begin{array}{l}\text { Análise da } \\
\text { imagem aérea } \\
1994\end{array}$ & \multicolumn{4}{|c|}{ Mata e gramínea. } \\
\hline Análise de campo & \multicolumn{4}{|c|}{$\begin{array}{l}\text { Rodovia, mata, ocupação residencial densa com construções de baixa qualidade a direita da entrada do túnel } \\
\text { e ocupação residencial esparsa a esquerda da entrada do túnel. Após } 1994 \text { foi construído o Rodoanel e o } \\
\text { túnel de acesso a Osasco. }\end{array}$} \\
\hline $\begin{array}{l}\text { Informações } \\
\text { complementares }\end{array}$ & & & & \\
\hline
\end{tabular}

\footnotetext{
${ }^{26}$ Rodoanel Mario Covas. Disponível em: <http://www.panoramio.com/photo/230903. Acesso em 28 set 2007.
} 


\begin{tabular}{|c|c|c|c|c|}
\hline Ano & Anterior a 2006 & 2007 & 2008 & 2009 \\
\hline Descrição & \multicolumn{4}{|c|}{ PONTO 60 - Jardim Jaraguá - Jaraguá } \\
\hline Fotos & & & & \\
\hline $\begin{array}{l}\text { Descriçãa das } \\
\text { fotos }\end{array}$ & $\begin{array}{l}\text { Entrada do túnel e } \\
\text { ocupação residencial } \\
\text { densa a direita, } \\
\text { Rodoanel }\end{array}$ & $\begin{array}{l}\text { Ocupação avançando na } \\
\text { mata do morro }\end{array}$ & $\begin{array}{l}\text { Entrada do túnel e } \\
\text { ocupação residencial densa } \\
\text { a direita, Rodoanel }\end{array}$ & $\begin{array}{c}\text { Entrada do túnel e } \\
\text { ocupação residencial } \\
\text { densa a direita, } \\
\text { Rodoanel, casa e posto } \\
\text { da DERSA a esquerda }\end{array}$ \\
\hline Números & $\begin{array}{c}\text { Foto } 110 \\
\text { Fonte: André Bonacin }{ }^{27}\end{array}$ & Foto 111 & Foto 112 & Foto 113 \\
\hline Fotos & 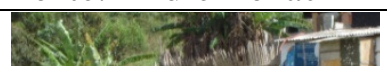 & Não há foto & & Não há foto \\
\hline $\begin{array}{l}\text { Descrição das } \\
\text { fotos }\end{array}$ & $\begin{array}{l}\text { Ocupação e rodovia } \\
\text { (Rodoanel) }\end{array}$ & & $\begin{array}{l}\text { Morro em cima do túnel, } \\
\text { ocupação residencial densa }\end{array}$ & \\
\hline Números & Foto 114 & & Foto 115 & \\
\hline
\end{tabular}

\footnotetext{
${ }^{27}$ Rodoanel Mario Covas. Disponível em: <http://www.panoramio.com/photo/230903. Acesso em 28 set 2007.
} 


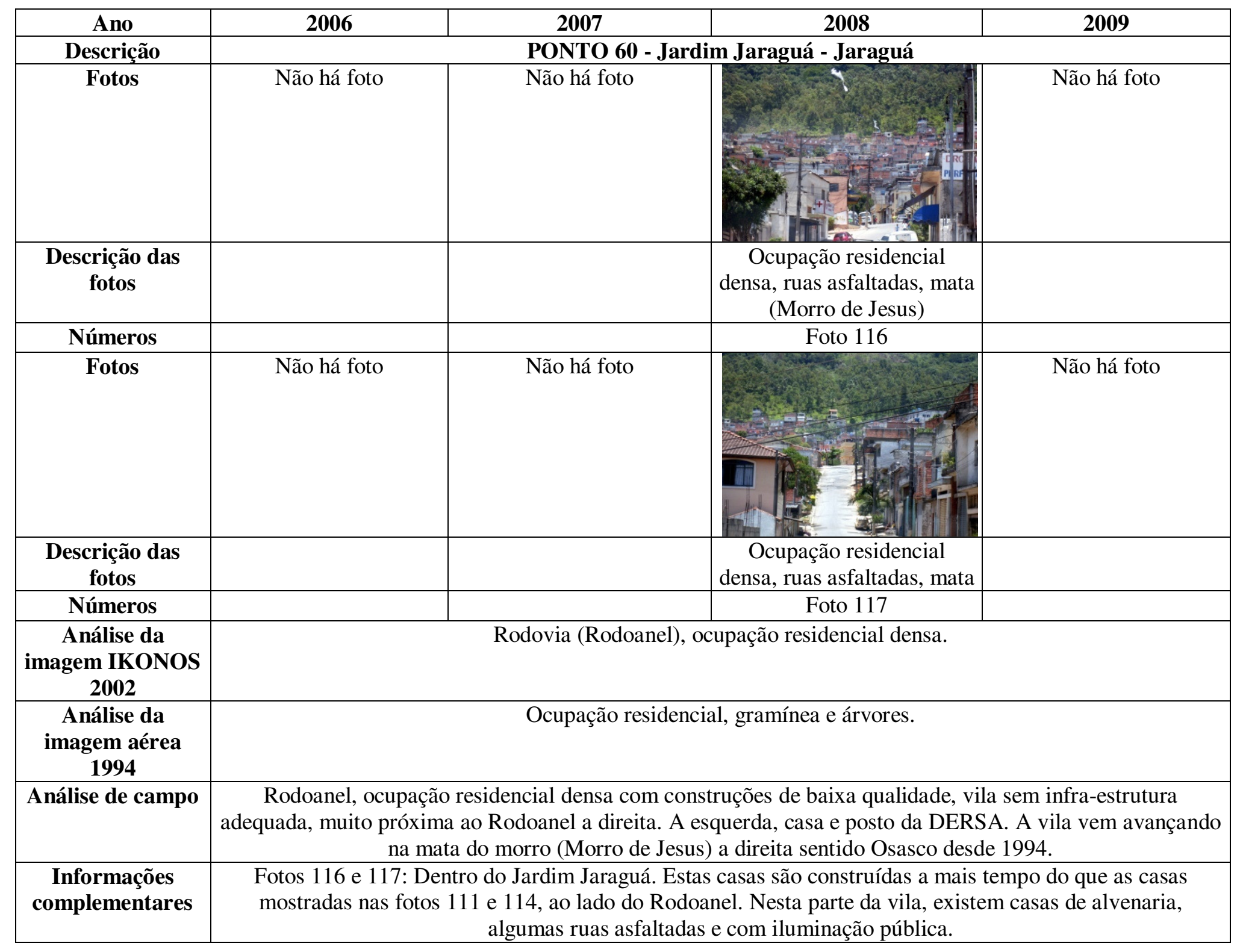

São Paulo 


\begin{tabular}{|c|c|c|c|c|}
\hline Ano & 2006 & 2007 & 2008 & 2009 \\
\hline Descrição & \multicolumn{4}{|c|}{ PONTO 61 - Vila Jaraguá - Jaraguá } \\
\hline Fotos & Não há foto & Não há foto & & trat \\
\hline $\begin{array}{l}\text { Descrição das } \\
\text { fotos }\end{array}$ & & & $\begin{array}{c}\text { Vila consolidada, ruas } \\
\text { asfaltadas }\end{array}$ & Galpões \\
\hline Números & & & Foto 118 & Foto 119 \\
\hline Fotos & Não há foto & Não há foto & & Não há foto \\
\hline $\begin{array}{c}\text { Descrição das } \\
\text { fotos }\end{array}$ & & & $\begin{array}{c}\text { Vila consolidada, ruas } \\
\text { asfaltadas }\end{array}$ & \\
\hline Números & & & Foto 120 & \\
\hline $\begin{array}{c}\text { Análise da } \\
\text { imagem IKONOS } \\
2002 \\
\end{array}$ & \multicolumn{4}{|c|}{ Ocupação residencial densa, rodovia (Anhanguera), passarela, galpão. } \\
\hline $\begin{array}{c}\text { Análise da } \\
\text { imagem aérea } \\
1994\end{array}$ & \multicolumn{4}{|c|}{ Ocupação residencial densa, rodovia (Anhanguera), passarela, galpão, gramínea e solo exposto. } \\
\hline Análise de campo & \multicolumn{4}{|c|}{$\begin{array}{c}\text { Ocupação residencial densa com construções de baixa qualidade, ruas asfaltadas. Vila muito próxima a } \\
\text { rodovia Anhanguera com acessos formais. Desde } 1994 \text { a ocupação residencial aumentou. Houve a } \\
\text { demolição de um galpão e a construção ainda não terminada de um prédio comercial do outro lado da } \\
\text { rodovia Anhanguera desde } 2002 .\end{array}$} \\
\hline
\end{tabular}

São Paulo 


\begin{tabular}{|c|c|c|c|c|}
\hline Ano & 2006 & 2007 & 2008 & 2009 \\
\hline Descrição & \multicolumn{4}{|c|}{ PONTO 62 - Jardim Esperança - Jaraguá } \\
\hline Fotos & Não há foto & Não há foto & & Não há foto \\
\hline $\begin{array}{l}\text { Descrição das } \\
\text { fotos }\end{array}$ & & & $\begin{array}{c}\text { Ocupação residencial densa } \\
\text { em terreno íngreme }\end{array}$ & \\
\hline Números & & & Foto 121 & \\
\hline $\begin{array}{l}\text { Análise da } \\
\text { imagem IKONOS } \\
2002\end{array}$ & \multicolumn{4}{|c|}{ Ocupação residencial densa, árvores. } \\
\hline $\begin{array}{l}\text { Análise da } \\
\text { imagem aérea } \\
1994\end{array}$ & \multicolumn{4}{|c|}{ Gramínea e árvores. } \\
\hline Análise de campo & \multicolumn{4}{|c|}{$\begin{array}{l}\text { Ocupação residencial densa com construções de baixa qualidade, ruas de terra. Em } 1994 \text { não havia ocupação } \\
\text { residencial. De acordo com entrevistas com moradores a ocupação residencial no local vem se expandindo } \\
\text { sem infra-estrutura adequada, principalmente em terrenos acidentados. }\end{array}$} \\
\hline $\begin{array}{c}\text { Informações } \\
\text { complementares }\end{array}$ & & & & \\
\hline
\end{tabular}









\begin{tabular}{|c|c|c|c|c|}
\hline Ano & 2006 & 2007 & 2008 & 2009 \\
\hline Descrição & \multicolumn{4}{|c|}{ PONTO 64 - Jardim Itaberaba II - Jaraguá } \\
\hline Fotos & Não há foto & Não há foto & & Não há foto \\
\hline Descrição das fotos & & & $\begin{array}{r}\text { Ocupação resi } \\
\text { fragmento d }\end{array}$ & \\
\hline Números & & & Foto 12 & \\
\hline $\begin{array}{l}\text { Análise da imagem } \\
\text { IKONOS } 2002\end{array}$ & \multicolumn{4}{|c|}{ Ocupação residencial, fragmento de mata e gramínea. } \\
\hline $\begin{array}{c}\text { Análise da imagem } \\
\text { aérea } 1994\end{array}$ & \multicolumn{4}{|c|}{ Fragmento de mata e gramínea. } \\
\hline Análise de campo & \multicolumn{4}{|c|}{$\begin{array}{l}\text { Ocupação residencial com construções recentes, de baixa qualidade, vila carente de infra-estrutura, em } \\
\text { crescimento. Em } 1994 \text { não havia ocupação residencial. A ocupação residencial avança no sentido do } \\
\text { fragmento de mata sem infra-estrutura adequada. Vila em constante crescimento de acordo com os } \\
\text { moradores. }\end{array}$} \\
\hline $\begin{array}{c}\text { Informações } \\
\text { complementares }\end{array}$ & & & & \\
\hline
\end{tabular}




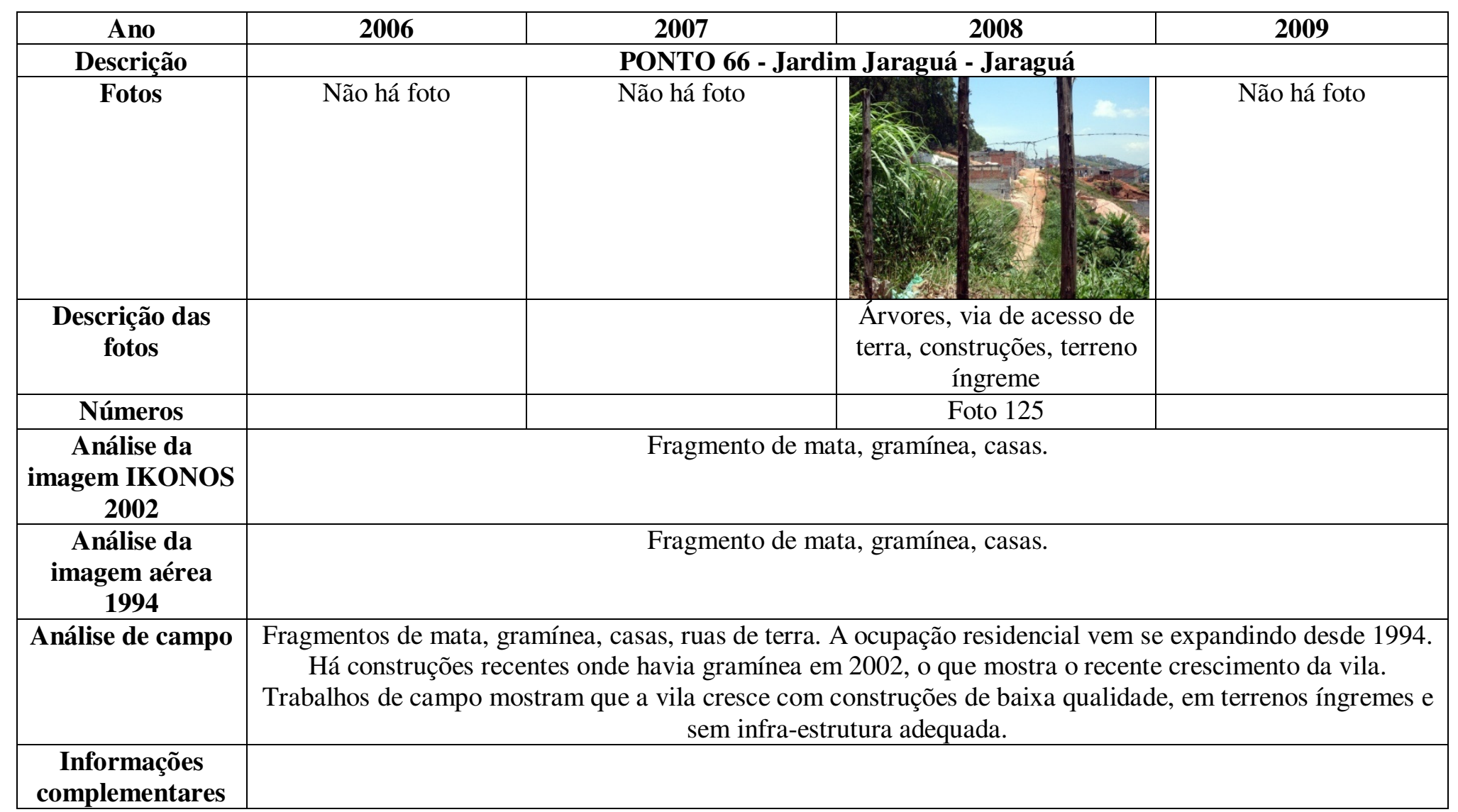




\begin{tabular}{|c|c|c|c|c|}
\hline Ano & 2006 & 2007 & 2008 & 2009 \\
\hline Descrição & \multicolumn{4}{|c|}{ PONTO 67 - Jaraguá } \\
\hline Fotos & Não há foto & Jão há fot & & Não há foto \\
\hline $\begin{array}{l}\text { Descrição das } \\
\text { fotos }\end{array}$ & & & $\begin{array}{l}\text { Fragmento de } n \\
\text { exposto e }\end{array}$ & \\
\hline Números & & & Foto 12 & \\
\hline $\begin{array}{c}\text { Análise da } \\
\text { imagem IKONOS } \\
2002\end{array}$ & \multicolumn{4}{|c|}{ Fragmento de mata e gramínea. } \\
\hline $\begin{array}{c}\text { Análise da } \\
\text { imagem aérea } \\
1994\end{array}$ & \multicolumn{4}{|c|}{ Fragmento de mata e gramínea. } \\
\hline Análise de campo & \multicolumn{4}{|c|}{$\begin{array}{l}\text { Fragmento de mata, gramínea, solo exposto,via de acesso informal e casa. Onde havia gramínea em } 1994 \text { e } \\
\text { 2002, há uma casa e área de solo exposto. }\end{array}$} \\
\hline $\begin{array}{c}\text { Informações } \\
\text { complementares }\end{array}$ & & & & \\
\hline
\end{tabular}




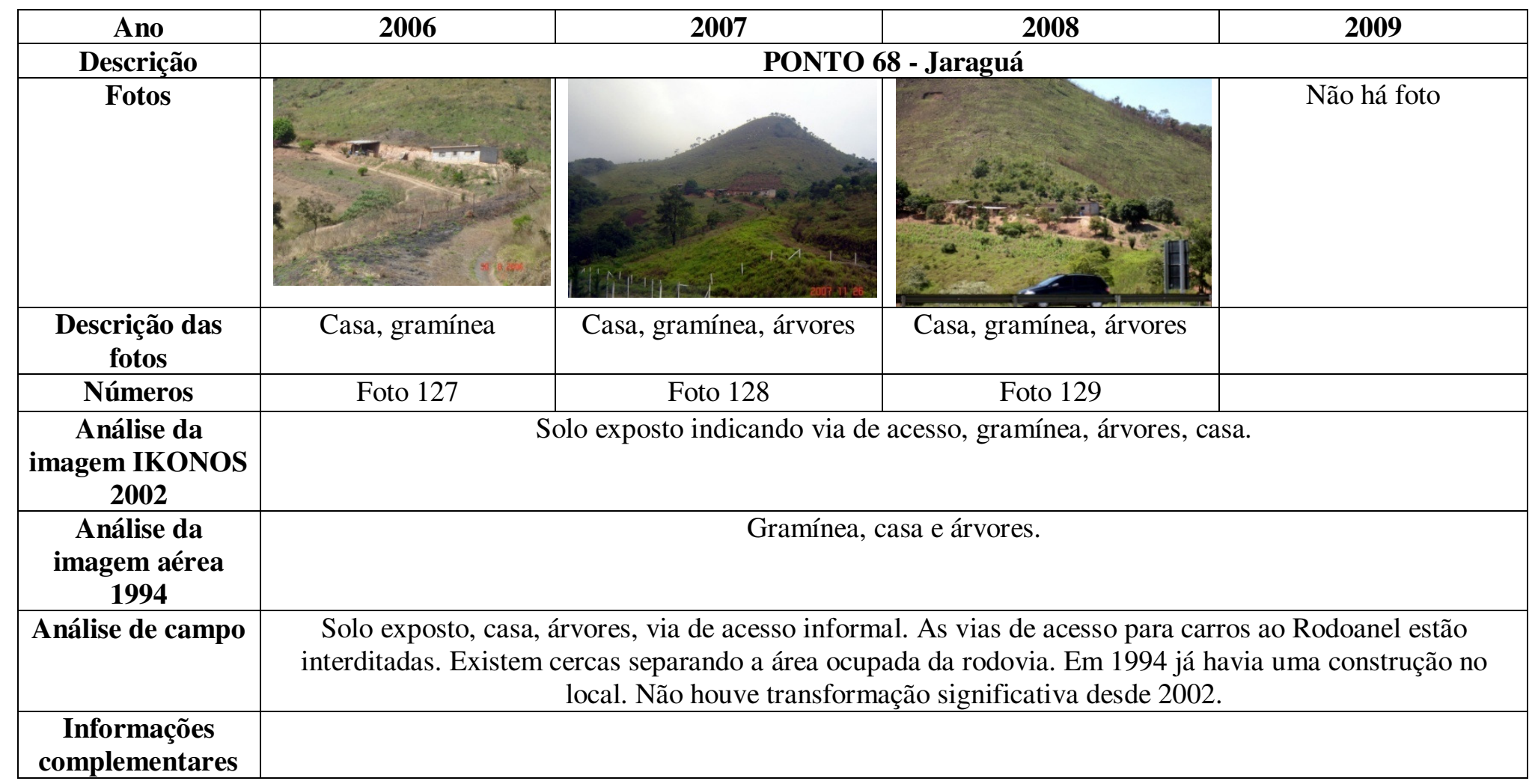




\begin{tabular}{|c|c|c|c|c|}
\hline Ano & 2006 & 2007 & 2008 & 2009 \\
\hline Descrição & \multicolumn{4}{|c|}{ PONTO 70 - Cemitério - Jaraguá } \\
\hline Fotos & Não há foto & Não há foto & & \\
\hline $\begin{array}{c}\begin{array}{c}\text { Descrição das } \\
\text { fotos }\end{array} \\
\end{array}$ & & & Terreno do cemitério & Terreno do cemitério \\
\hline Números & & & Foto 130 & Foto 131 \\
\hline Fotos & Não há foto & Não há foto & Não há foto & \\
\hline $\begin{array}{c}\begin{array}{c}\text { Descrição das } \\
\text { fotos }\end{array} \\
\end{array}$ & & & & Velório do cemitério \\
\hline Números & & & & Foto 132 \\
\hline $\begin{array}{c}\text { Análise da } \\
\text { imagem IKONOS } \\
2002 \\
\end{array}$ & \multicolumn{4}{|c|}{ Construção (velório) e gramínea (terreno do cemitério). } \\
\hline $\begin{array}{c}\text { Análise da } \\
\text { imagem aérea } \\
1994\end{array}$ & \multicolumn{4}{|c|}{ Solo exposto, galpão e fragmento de mata. } \\
\hline Análise de campo & \multicolumn{4}{|c|}{$\begin{array}{l}\text { Construção para velório e terreno para enterros vistos da rodovia Anhanguera. Em } 1994 \text { ainda não havia o } \\
\text { velório e o cemitério. Não houve transformação significativa desde } 2002 .\end{array}$} \\
\hline $\begin{array}{l}\text { Informações } \\
\text { complementares }\end{array}$ & \multicolumn{4}{|c|}{ Cemitério Gethsemani } \\
\hline
\end{tabular}




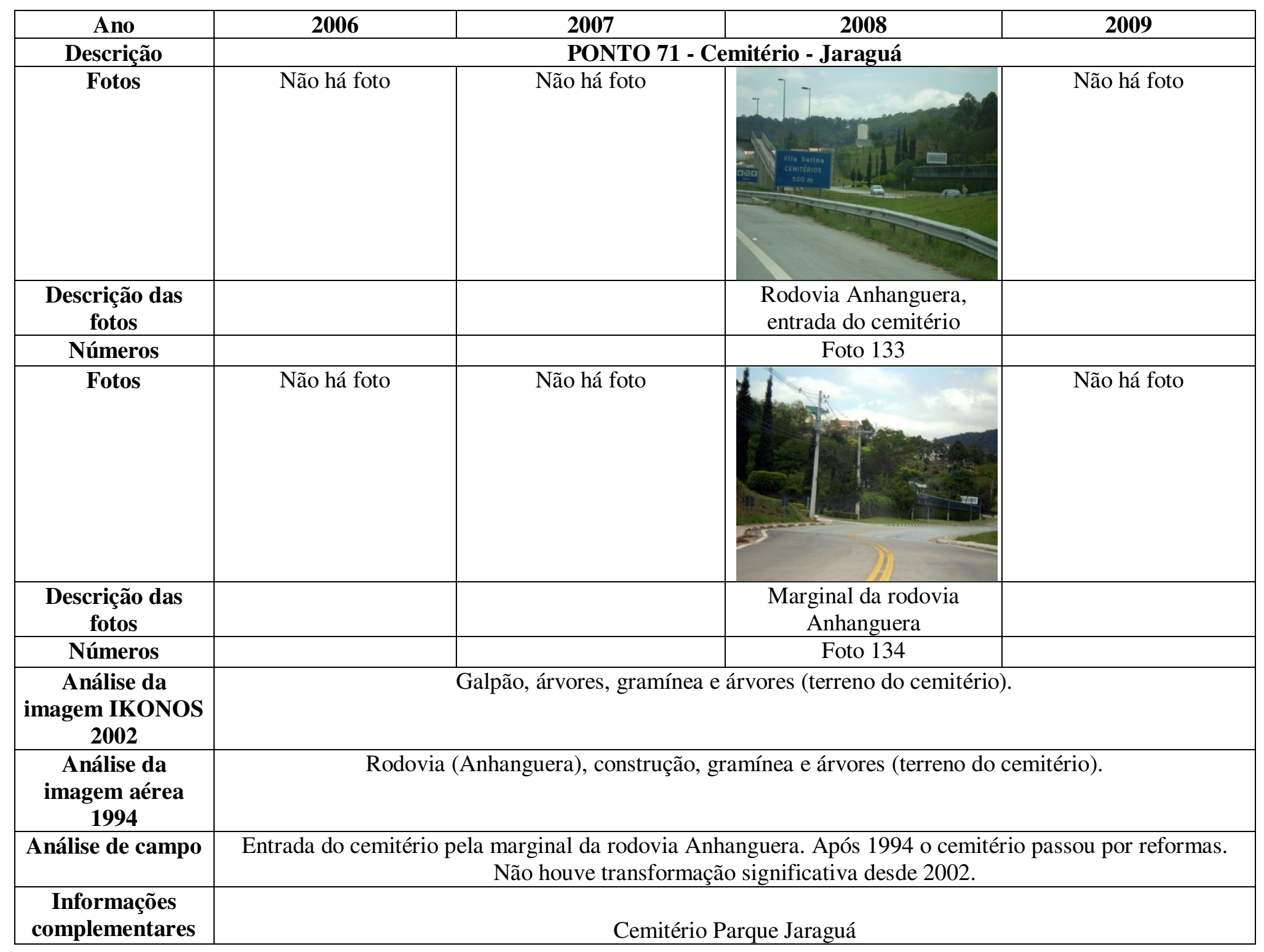

São Paulo 


\begin{tabular}{|c|c|c|c|c|}
\hline Ano & 2006 & 2007 & 2008 & 2009 \\
\hline Descrição & \multicolumn{4}{|c|}{ PONTO 76 - Vila Sol Nascente - Perus } \\
\hline \multicolumn{5}{|l|}{ Fotos } \\
\hline $\begin{array}{l}\text { Descrição das } \\
\text { fotos }\end{array}$ & & & $\begin{array}{l}\text { Ocupação residencial } \\
\text { densa, árvores esparsas, } \\
\text { terreno íngreme }\end{array}$ & $\begin{array}{l}\text { Ocupação residencial } \\
\text { densa, árvores esparsas, } \\
\text { terreno íngreme }\end{array}$ \\
\hline Números & & & Foto 135 & Foto 136 \\
\hline $\begin{array}{l}\text { Análise da } \\
\text { imagem IKONOS } \\
2002 \\
\end{array}$ & \multicolumn{4}{|c|}{ Ocupação residencial densa, árvores. } \\
\hline $\begin{array}{l}\text { Análise da } \\
\text { imagem aérea } \\
1994\end{array}$ & \multicolumn{4}{|c|}{ Solo exposto, ocupação residencial, árvores. } \\
\hline Análise de campo & \multicolumn{4}{|c|}{$\begin{array}{l}\text { Ocupação residencial densa, fragmento de mata, ruas de terra, áreas de risco (moradias em terrenos } \\
\text { íngremes, solo exposto, pontos de erosão e escorregamento). A ocupação residencial se intensificou após } \\
\text { 1994. Segundo moradores, a vila vem crescendo desde } 2002 \text {, sem infra-estrutura adequada. }\end{array}$} \\
\hline $\begin{array}{c}\text { Informações } \\
\text { complementares }\end{array}$ & & & & \\
\hline
\end{tabular}




\begin{tabular}{|c|c|c|c|c|}
\hline Ano & 2006 & 2007 & 2008 & 2009 \\
\hline Descrição & \multicolumn{4}{|c|}{ PONTO 78 - Jaraguá } \\
\hline Fotos & Não há foto & Não há foto & & Não há foto \\
\hline $\begin{array}{l}\text { Descrição das } \\
\text { fotos }\end{array}$ & & & $\begin{array}{l}\text { Cruzamento das rodovias } \\
\text { Anhanguera e Rodoanel, } \\
\text { vila }\end{array}$ & \\
\hline Números & & & Foto 137 & \\
\hline $\begin{array}{l}\text { Análise da } \\
\text { imagem IKONOS } \\
2002\end{array}$ & \multicolumn{4}{|c|}{ Cruzamento das rodovias (Anhanguera e Rodoanel). } \\
\hline $\begin{array}{l}\text { Análise da } \\
\text { imagem aérea } \\
1994\end{array}$ & \multicolumn{4}{|c|}{ Rodovia (Anhanguera) e árvores. } \\
\hline Análise de campo & \multicolumn{4}{|c|}{$\begin{array}{l}\text { Cruzamento das rodovias Anhanguera e Rodoanel. Túnel de acesso a Osasco e ocupação residencial } \\
\text { (Jardim Jaraguá). Após } 1998 \text { foi construído o Rodoanel e alças de acesso a rodovia Anhanguera. Próximo ao } \\
\text { cruzamento foi construído um posto da DERSA. Não houve transformação significativa desde } 2002 .\end{array}$} \\
\hline $\begin{array}{c}\text { Informações } \\
\text { complementares }\end{array}$ & & 37 & n Jaraguá, ao fundo. & \\
\hline
\end{tabular}




\begin{tabular}{|c|c|c|c|c|}
\hline Ano & 2006 & 2007 & 2008 & 2009 \\
\hline Descrição & \multicolumn{4}{|c|}{ PONTO 80 - Jaraguá } \\
\hline Fotos & Não há foto & Não há foto & & Não há foto \\
\hline $\begin{array}{l}\text { Descrição das } \\
\text { fotos }\end{array}$ & & & Casa, talude e vila ao fundo & \\
\hline Números & & & Foto 138 & \\
\hline $\begin{array}{c}\text { Análise da } \\
\text { imagem IKONOS } \\
2002\end{array}$ & \multicolumn{4}{|c|}{ Casa e taludes estabilizados com gramínea. } \\
\hline $\begin{array}{c}\text { Análise da } \\
\text { imagem aérea } \\
1994\end{array}$ & \multicolumn{4}{|c|}{ Casa solo exposto e fragmento de mata. } \\
\hline Análise de campo & \multicolumn{4}{|c|}{$\begin{array}{l}\text { Casa, taludes estabilizados, Rodoanel. Após } 1994 \text { foi construído o Rodoanel. Não houve transformação } \\
\text { significativa desde } 2002 .\end{array}$} \\
\hline $\begin{array}{l}\text { Informações } \\
\text { complementares }\end{array}$ & \multicolumn{4}{|c|}{ Foto 138: Ocupação residencial densa com construções de baixa qualidade (Vila Sol Nascente) ao fundo. } \\
\hline
\end{tabular}




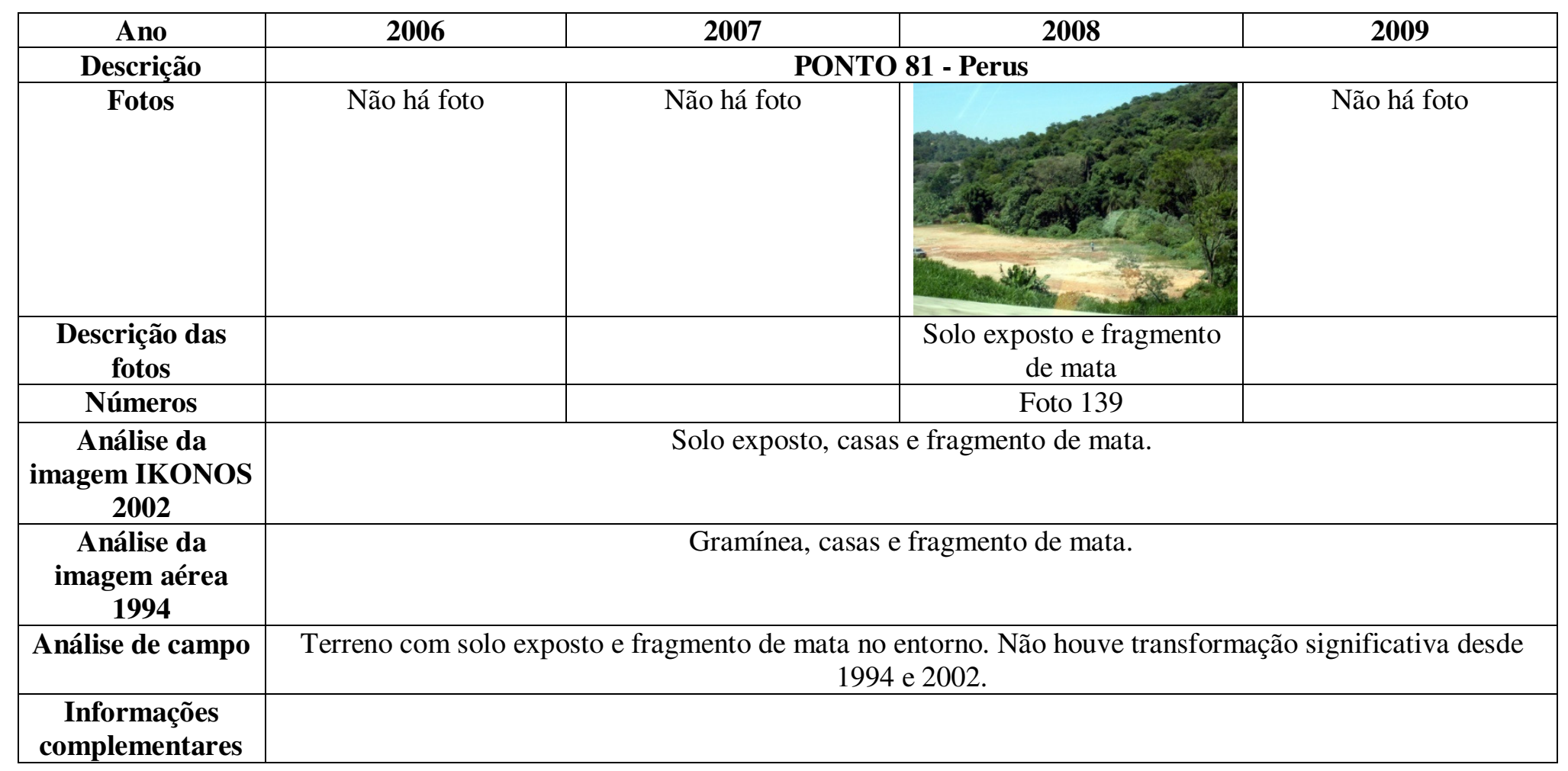




\begin{tabular}{|c|c|c|c|c|}
\hline Ano & 2006 & 2007 & 2008 & 2009 \\
\hline Descrição & \multicolumn{4}{|c|}{ PONTO 82 - Perus } \\
\hline Fotos & Não há foto & Não há foto & & Não há foto \\
\hline $\begin{array}{l}\text { Descrição das } \\
\text { fotos }\end{array}$ & & & Rodoanel e alças & \\
\hline Números & & & Foto 14 & \\
\hline $\begin{array}{c}\text { Análise da } \\
\text { imagem IKONOS } \\
2002\end{array}$ & \multicolumn{4}{|c|}{ Final da rodovia (Rodoanel), alças de acesso para avenida (Raimundo P. de Magalhães). } \\
\hline $\begin{array}{c}\text { Análise da } \\
\text { imagem aérea } \\
1994\end{array}$ & \multicolumn{4}{|c|}{ Vias de acesso. } \\
\hline Análise de campo & \multicolumn{4}{|c|}{$\begin{array}{l}\text { Após } 1994 \text { foi construído o Rodoanel e alças de acesso para a avenida Raimundo P. de Magalhães e para a } \\
\text { antiga Estrada Velha de Campinas. Não houve transformação significativa desde } 2002 .\end{array}$} \\
\hline $\begin{array}{c}\text { Informações } \\
\text { complementares }\end{array}$ & \multicolumn{4}{|c|}{ Avenida Raimundo P. de Magalhães é acesso a Antiga Estrada Velha de Campinas (SP-332). } \\
\hline
\end{tabular}




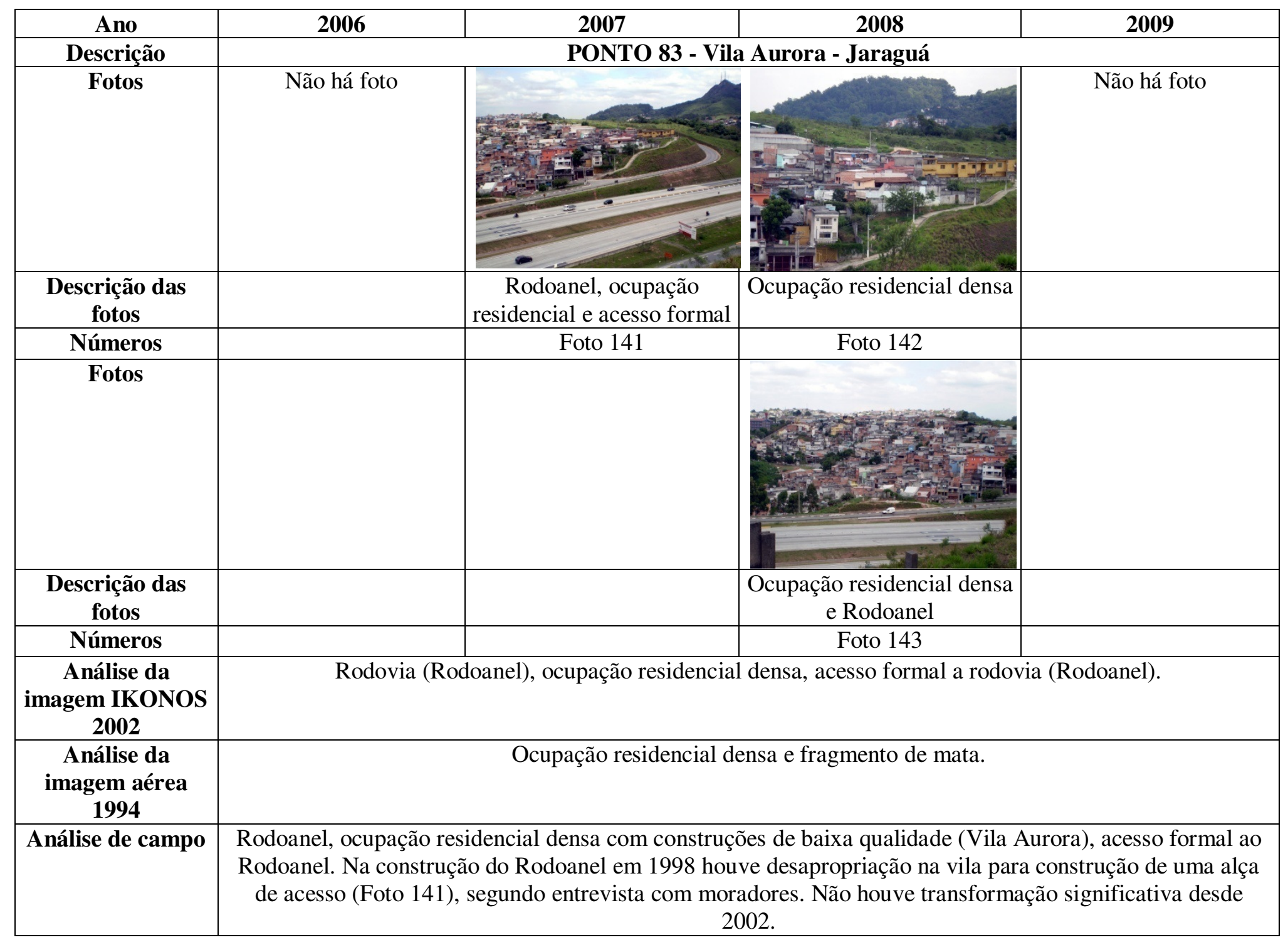




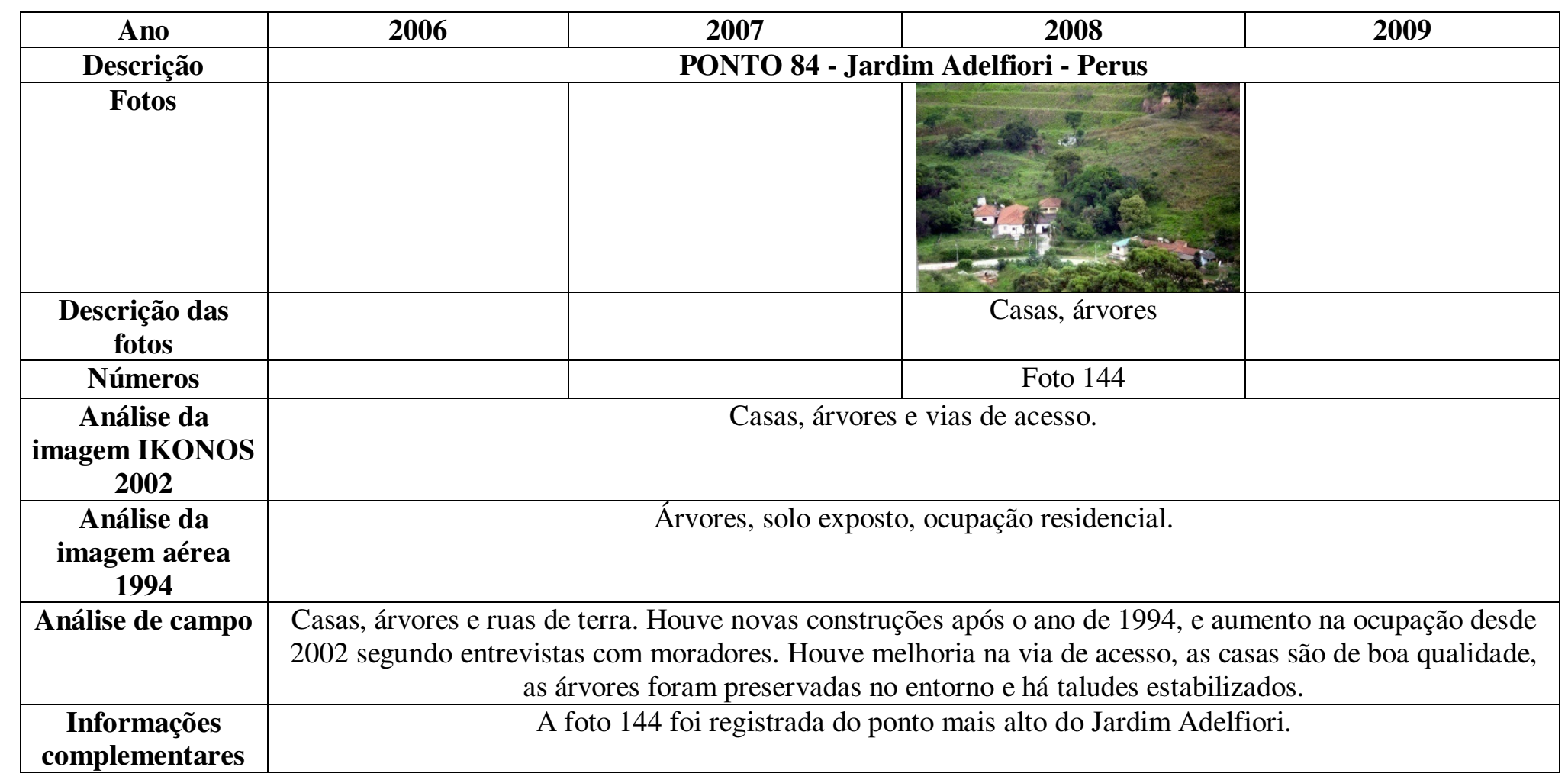




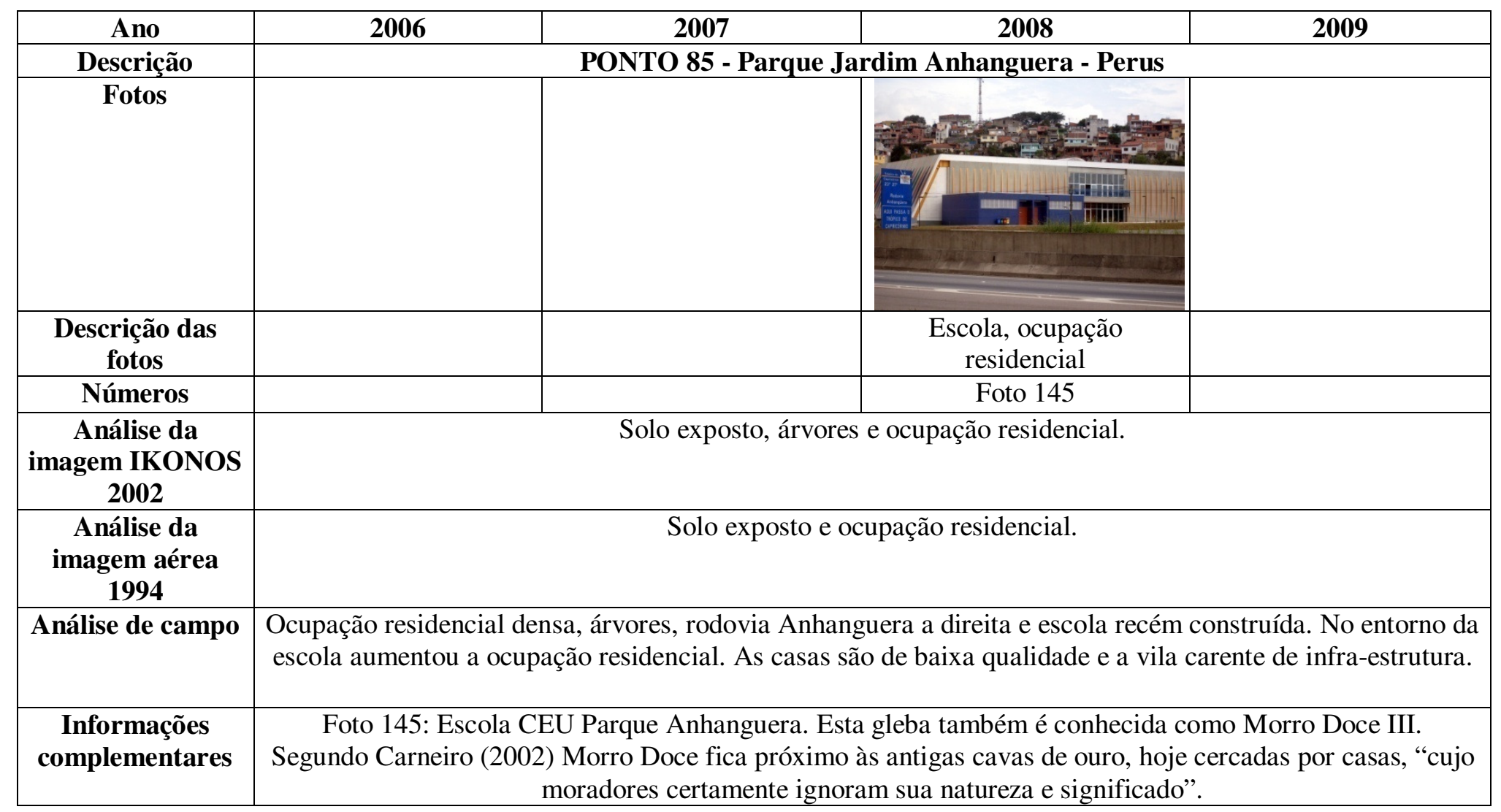




\begin{tabular}{|c|c|c|c|c|}
\hline Ano & 2006 & 2007 & 2008 & 2009 \\
\hline Descrição & \multicolumn{4}{|c|}{ PONTO 86 - Vila Sol Nascente - Perus } \\
\hline \multicolumn{5}{|l|}{ Fotos } \\
\hline $\begin{array}{l}\text { Descrição das } \\
\text { fotos }\end{array}$ & & $\begin{array}{c}\text { Ocupação residencial e } \\
\text { árvores }\end{array}$ & $\begin{array}{l}\text { Rua asfaltada, terrenos com } \\
\text { árvores a esquerda e } \\
\text { construções a direita }\end{array}$ & \\
\hline Números & & Foto 146 & Foto 147 & \\
\hline \multicolumn{5}{|l|}{ Fotos } \\
\hline $\begin{array}{l}\text { Descrição das } \\
\text { fotos }\end{array}$ & & & Praça da vila & \\
\hline Números & & & Foto 148 & \\
\hline $\begin{array}{l}\text { Análise da } \\
\text { imagem IKONOS } \\
2002 \\
\end{array}$ & \multicolumn{4}{|c|}{ Ocupação residencial densa, árvores, praça. } \\
\hline $\begin{array}{l}\text { Análise da } \\
\text { imagem aérea } \\
1994\end{array}$ & \multicolumn{4}{|c|}{ Solo exposto. } \\
\hline Análise de campo & \multicolumn{4}{|c|}{$\begin{array}{l}\text { Ocupação residencial densa, árvores, praça e ruas de terra. A ocupação residencial ocorreu após } 1994 . \\
\text { Houve aumento no número de construções desde } 2002 \text { e também na infra-estrutura, segundo entrevista com } \\
\text { moradores. A partir de } 2007 \text { há atuação da Prefeitura buscando informar e evitar a construção de moradias }\end{array}$} \\
\hline
\end{tabular}




\begin{tabular}{|c|c|c|c|c|}
\hline & \multicolumn{4}{|c|}{ novas em lugares irregulares. } \\
\hline Informações & \multicolumn{4}{|c|}{ Em trabalho de campo foram observadas diversas placas com avisos de restrições sobre as novas ocupações. } \\
\hline Ano & 2006 & 2007 & 2008 & 2009 \\
\hline Descrição & \multicolumn{4}{|c|}{ PONTO 87 - Recanto da Paz - Perus } \\
\hline Fotos & & & & \\
\hline $\begin{array}{l}\text { Descrição das } \\
\text { fotos }\end{array}$ & $\begin{array}{l}\text { Acesso informal para } \\
\text { carros interditado }\end{array}$ & & $\begin{array}{c}\text { Rodoanel e acesso a favela } \\
\text { na marginal }\end{array}$ & \\
\hline Números & Foto 149 & & Foto 150 & \\
\hline Fotos & & & & \\
\hline $\begin{array}{l}\text { Descrição das } \\
\text { fotos }\end{array}$ & $\begin{array}{c}\text { Acesso para pedestres } \\
\text { informal }\end{array}$ & & Favela e acessos informais & \\
\hline Números & Foto 151 & & Foto 152 & \\
\hline
\end{tabular}




\begin{tabular}{|c|c|c|c|c|}
\hline Ano & 2006 & 2007 & 2008 & 2009 \\
\hline \multicolumn{5}{|c|}{ PONTO 87 - Recanto da Paz - Perus } \\
\hline Fotos & 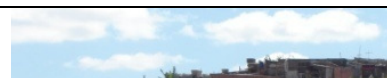 & & & \\
\hline $\begin{array}{c}\text { Descrição das } \\
\text { fotos } \\
\end{array}$ & $\begin{array}{c}\text { Favelização com acesso } \\
\text { informal ao Rodoanel }\end{array}$ & & Favela, campinho de lazer & $\begin{array}{c}\text { Favelização com acesso } \\
\text { informal ao Rodoanel }\end{array}$ \\
\hline Números & Foto 153 & & Foto 154 & Foto 155 \\
\hline \multicolumn{5}{|l|}{ Fotos } \\
\hline $\begin{array}{l}\text { Descrição das } \\
\text { fotos }\end{array}$ & $\begin{array}{c}\text { Acesso informal para } \\
\text { pedestres }\end{array}$ & $\begin{array}{c}\text { Acesso informal para } \\
\text { pedestres }\end{array}$ & $\begin{array}{l}\text { Acesso informal para } \\
\text { pedestres }\end{array}$ & \\
\hline Números & Foto 156 & Foto 157 & Foto 158 & \\
\hline $\begin{array}{l}\text { Análise da } \\
\text { imagem IKONOS } \\
2002\end{array}$ & \multicolumn{4}{|c|}{ Acesso informal a favela (Recanto da Paz e a vila Recanto dos Humildes), favela, rodovia (Rodoanel). } \\
\hline $\begin{array}{l}\text { Análise da } \\
\text { imagem aérea } \\
1994\end{array}$ & \multicolumn{4}{|c|}{ Fragmento de mata. } \\
\hline Análise de campo & \multicolumn{4}{|c|}{$\begin{array}{l}\text { Acesso informal a favela Recanto da Paz e a vila Recanto dos Humildes, favela, Rodoanel. Em } 1994 \text { não } \\
\text { havia a favela, nem a vila, não havia acessos e o Rodoanel. Segundo moradores do local, a favela está em } \\
\text { crescimento desde } 2002 \text { e os acessos ao Rodoanel vem sendo utilizado por pedestres. }\end{array}$} \\
\hline
\end{tabular}

São Paulo 


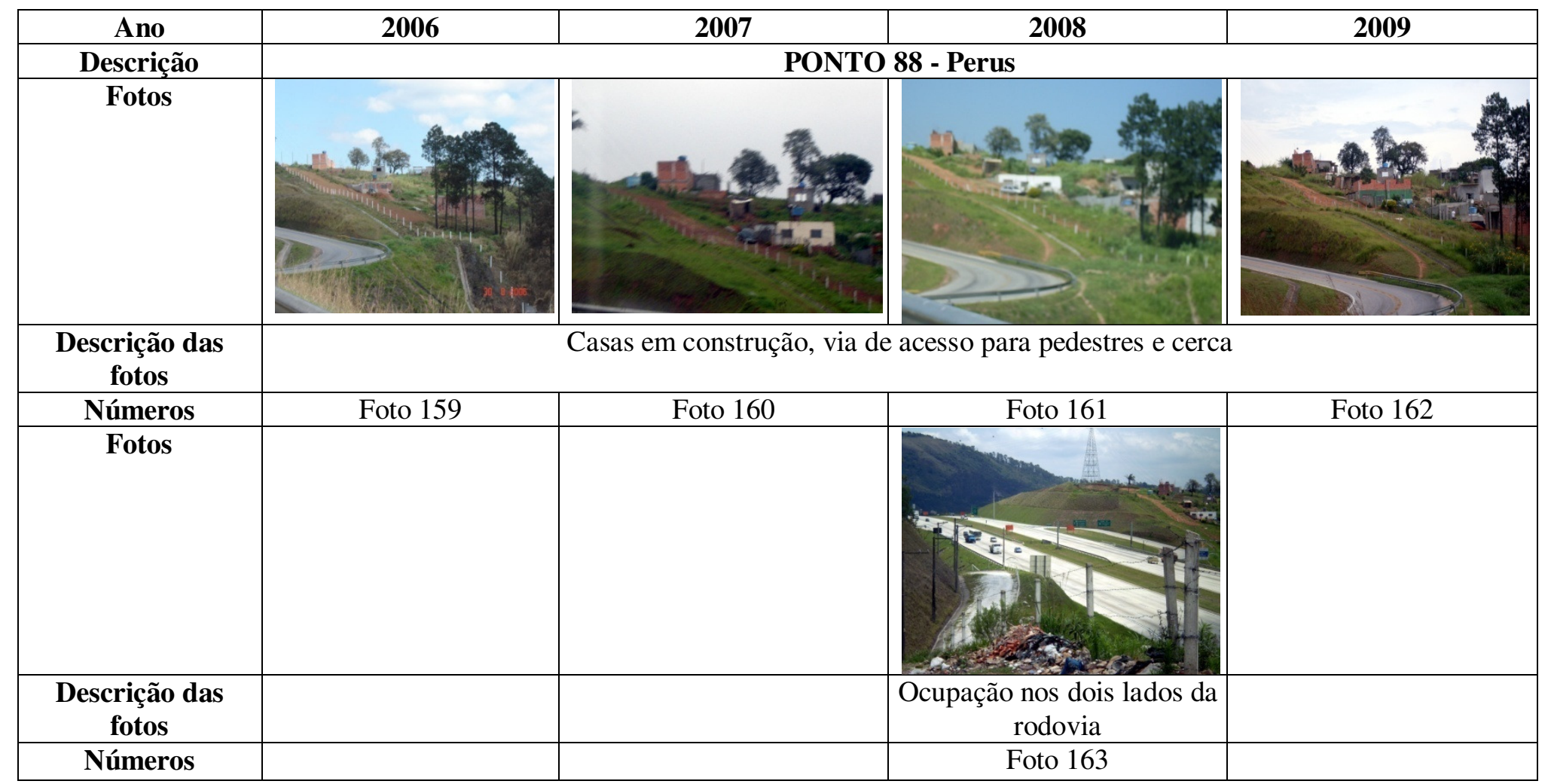




\begin{tabular}{|c|c|c|c|c|}
\hline Ano & 2006 & 2007 & 2008 & 2009 \\
\hline \multicolumn{5}{|c|}{ PONTO 88 - Perus } \\
\hline Fotos & & & 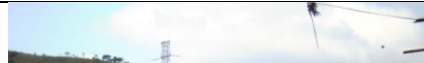 & \\
\hline $\begin{array}{l}\text { Descrição das } \\
\text { fotos }\end{array}$ & & & $\begin{array}{c}\text { Alças de retorno passando } \\
\text { por baixo do Rodoanel }\end{array}$ & \\
\hline Números & & & Foto 164 & \\
\hline $\begin{array}{l}\text { Análise da } \\
\text { imagem IKONOS } \\
2002\end{array}$ & \multicolumn{4}{|c|}{ Alças de retorno da rodovia (Rodoanel), solo exposto, gramínea, ocupação, via de acesso de terra } \\
\hline $\begin{array}{l}\text { Análise da } \\
\text { imagem aérea } \\
1994\end{array}$ & \multicolumn{4}{|c|}{ Casa (ou galpão) e solo exposto. } \\
\hline Análise de campo & \multicolumn{4}{|c|}{$\begin{array}{c}\text { Cerca que separa a rodovia das casas, vias de acesso de terra para pedestres, não há via de acesso para carros } \\
\text { unida diretamente a rodovia, gramínea. Havia uma construção em } 1994 \text {. Posteriormente foi construído o } \\
\text { Rodoanel e alças de retorno. Algumas outras casas foram sendo construídas desde } 2002 \text {, mas percebe-se que } \\
\text { o crescimento é muito lento nesta área. }\end{array}$} \\
\hline $\begin{array}{c}\text { Informações } \\
\text { complementares }\end{array}$ & \multicolumn{4}{|c|}{ A foto 163 mostra a ocupação vista do outro lado da rodovia. } \\
\hline
\end{tabular}




\begin{tabular}{|c|c|c|c|c|}
\hline Ano & 2006 & 2007 & 2008 & 2009 \\
\hline Descrição & \multicolumn{4}{|c|}{ PONTO 89 - Jaraguá } \\
\hline \multicolumn{5}{|l|}{ Fotos } \\
\hline $\begin{array}{c}\text { Descrição das } \\
\text { fotos }\end{array}$ & & & ude, gal & \\
\hline Números & & & Foto 16 & \\
\hline \multicolumn{5}{|l|}{ Fotos } \\
\hline $\begin{array}{l}\text { Descrição das } \\
\text { fotos }\end{array}$ & & & rada de & \\
\hline Números & & & Foto 16 & \\
\hline $\begin{array}{c}\text { Análise da } \\
\text { imagem IKONOS } \\
2002\end{array}$ & \multicolumn{4}{|c|}{ Solo exposto, galpões, fragmentos de mata, via de acesso informal ao Rodoanel. } \\
\hline $\begin{array}{c}\text { Análise da } \\
\text { imagem aérea } \\
1994\end{array}$ & \multicolumn{4}{|c|}{ Casas (ou galpão), solo exposto e fragmento de mata. } \\
\hline Análise de campo & \multicolumn{4}{|c|}{$\begin{array}{c}\text { Talude, fragmentos de mata, galpões, via de acesso informal. Após } 1994 \text { houve aumento na ocupação } \\
\text { residencial. Não houve transformação significativa desde } 2002 .\end{array}$} \\
\hline $\begin{array}{c}\text { Informações } \\
\text { complementares }\end{array}$ & & & & \\
\hline
\end{tabular}




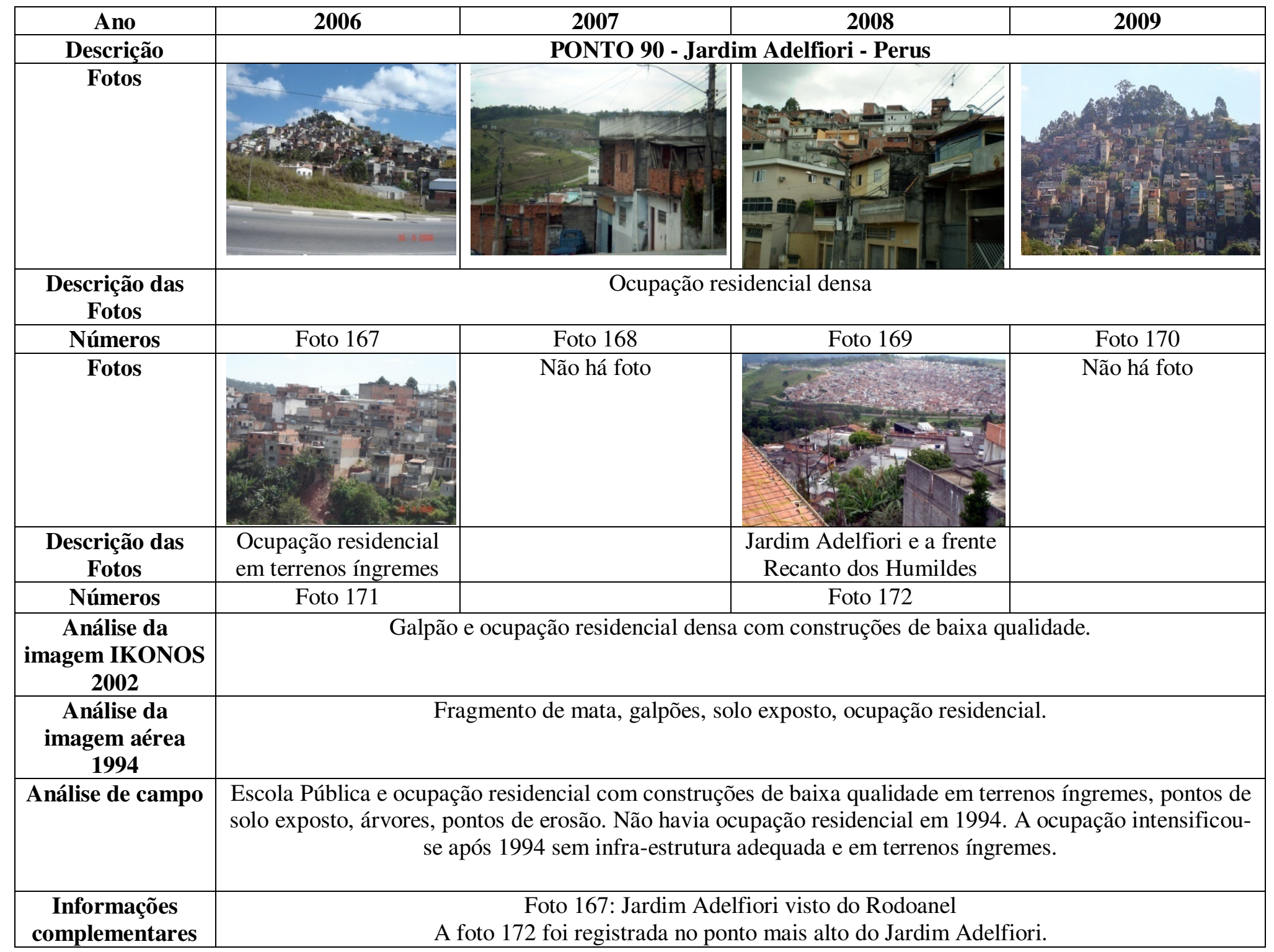




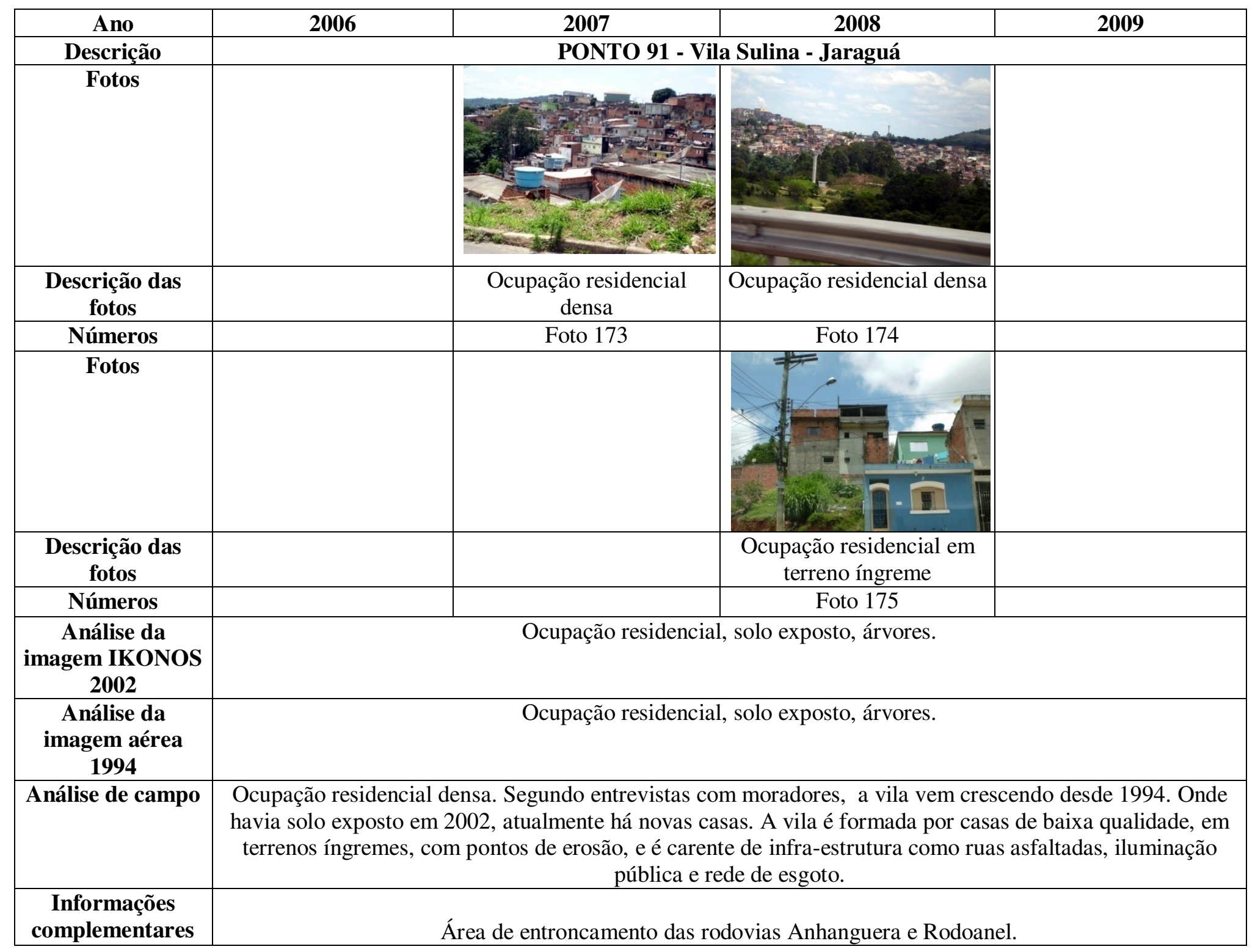

São Paulo 


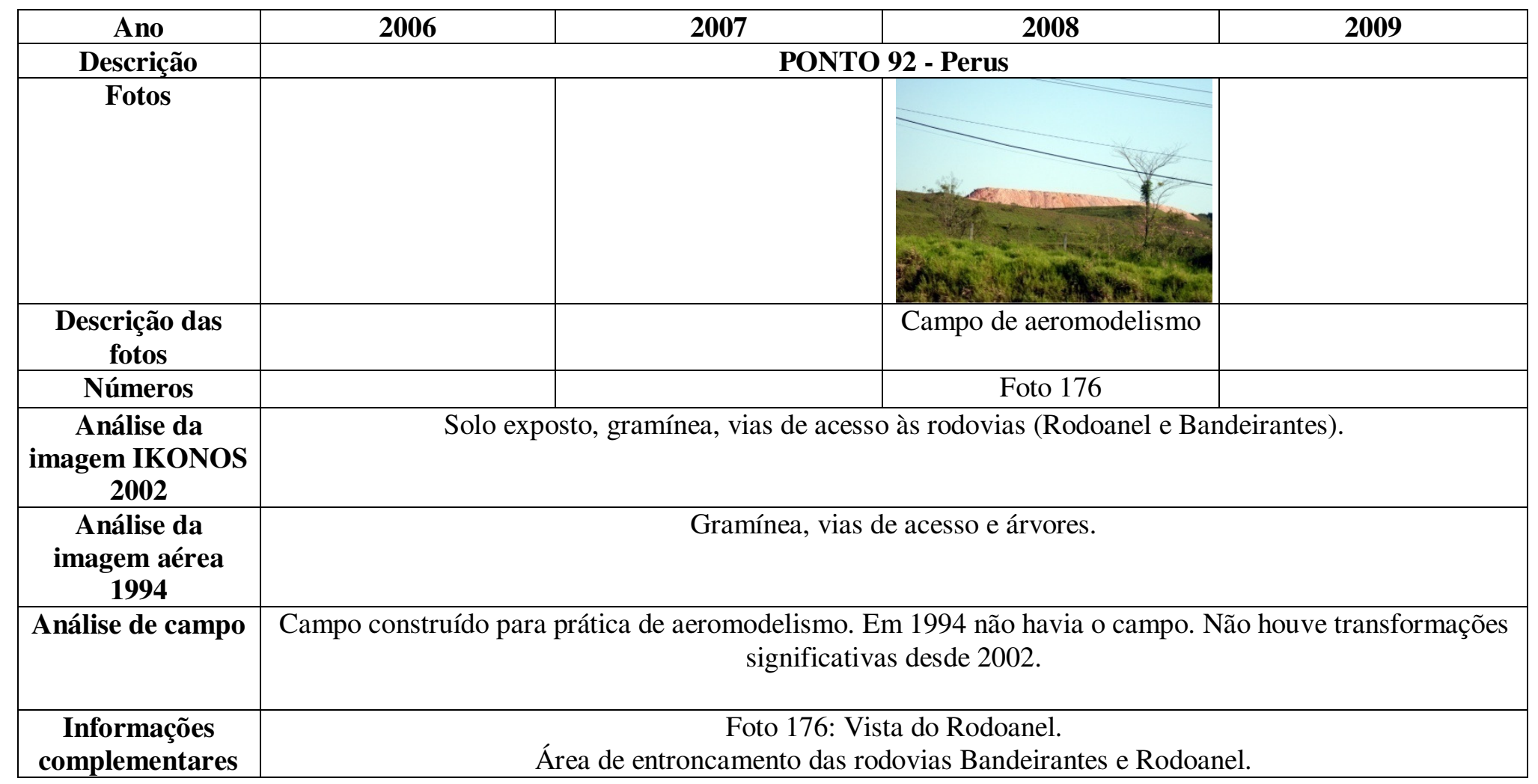




\subsubsection{Ocupação no trecho oeste do Rodoanel após o túnel de acesso a Osasco}

No entorno de rodovias de tráfego intenso, a compra e venda de espaços tornaram-se intensas, impondo uma forte dinâmica de competição em diversos setores do mercado imobiliário que negocia espaços como mercadoria de consumo.

$\mathrm{O}$ crescimento de atividades industriais / empresariais ocorreu em todos os municípios por onde passa o Rodoanel, pois estes municípios, assim como os outros da RMSP, encontram-se em expansão. Pode-se dizer, por anúncios em jornais, imobiliários e in loco, que a construção do Rodoanel deu um "empurrão" no mercado imobiliário, da mesma forma que as outras rodovias. Em São Paulo, todo acesso que facilite chegar ao centro urbano, ao interior ou às outras rodovias são bem vistos pelos compradores e empreendedores. Em alguns municípios houve maior crescimento residencial, enquanto que em outros, houve maior crescimento industrial / empresarial, e este crescimento foi direcionado principalmente pela legislação do uso e ocupação do solo, suas atualizações e incentivos fiscais.

A construção das rodovias no estado de São Paulo nas décadas de 1960 e 1970, a descentralização industrial e o crescimento do interior do estado, auxiliou a atual caracterização das cidades na RMSP, o que norteia em muitos casos novas ocupações. Atualmente, com a construção do Rodoanel, surgiu mais uma vantagem para compradores e empreendedores na região, agindo em conjunto com as rodovias radiais e, aos poucos, com as administrações municipais.

O trecho do Rodoanel que corta Osasco ilustra uma concentração de empresas próximas à rodovia como forma de permanecerem próximas a metrópole (proximidade ocasionada pelo fácil acesso), mas não em seu interior. "Os locais de grande concentração de Zona Industrial estão ao longo da Rodovia Castello Branco (Osasco e Barueri) e do Rodoanel (Osasco e Embu).” (FAUUSP, 2005, p.89).

Segundo Portal do Governo do Estado de São Paulo ${ }^{28}$, “Osasco recebeu 172 empresas de médio e grande porte entre 1995 e 2003, do anúncio do projeto à execução das obras [므o Rodoanel]." O secretário de Habitação de Osasco, Sérgio Gonçalves, explica que "áreas foram valorizadas pela saída rápida para rodovias”.

28 SÃO PAULO. PIB ao longo do trecho oeste cresce 3 vezes mais. Disponível em: http://www.saopaulo.sp.gov.br/spnoticias/lenoticia.php?id=202807\&c=5023. Acesso em 20 jul 2009. (grifo da autora) 
$\mathrm{Na}$ década de 90 percebeu-se uma maior concentração de empresas nas proximidades da cidade de São Paulo e, para a década de 2000 uma maior dispersão e aproximação destas empresas ao longo das rodovias e do rodoanel, o que caracterizou respectivamente eixos horizontais e verticais na concentração de empresas no município (ALMEIDA, 2006, p.109-110).

Outro fator favorável para a ocupação industrial / empresarial é que o município de Osasco apresentou a vantagem de ter uma legislação municipal atualizada após a construção do Rodoanel, com a preocupação com os incentivos que a rodovia poderia causar no município.

Pelo menos no que tange à atividade empresarial, o Rodoanel em seu Trecho Oeste parece estar sendo catalisador de novos empreendimentos, como aliás a própria DERSA previra. Isso gera processos de valorização fundiária e de aumento dos assentamentos informais, sendo que existe um número razoável de acessos informais à via, que mostram o quão difícil será a fiscalização desse fenômeno. (FAUUSP, 2005, p.122)

Embora Osasco seja considerado densamente ocupado antes mesmo da construção do Rodoanel, pode-se dizer que esta acessibilidade também impulsionou novas negociações imobiliárias residenciais. "Há um aumento na procura de residências de 2 e 3 dormitórios por famílias que querem sair de São Paulo, e são estimuladas pela acessibilidade / mobilidade gerada com o Rodoanel" (FAUUSP, 2005, p. 71).

Nos municípios de Osasco e Carapicuíba houve áreas de apropriação de três terrenos próximos a rodovia para reassentar moradores retirados de outros trechos do Rodoanel. Houve a instalação de infra-estrutura como luz, água e esgoto. "Foram construídos três empreendimentos habitacionais: Residencial Rodoanel Osasco, com 566 unidades habitacionais; Residencial Rodoanel Padroeira, também em Osasco, com 236 unidades habitacionais; e Residencial Rodoanel Carapicuíba, com 297 unidades habitacionais, totalizando 1099 unidades construídas." (FAUUSP, 2005, p. 114).

No município de Barueri foi possível observar em trabalho de campo que o Rodoanel está inserido num adensamento populacional misto, com usos residenciais, empresariais e industriais, sendo que as empresas e indústrias estão localizadas próximas a Osasco, no entroncamento do Rodoanel com a rodovia Castello Branco, tendo assim, o acesso facilitado pelas duas rodovias. Segundo Folgato (2004) 
Loteamentos a 1,5 km do Rodoanel, em Barueri e Santana de Parnaíba, valorizaram pelo menos $400 \%$ desde o início das obras, em 1999. Mais de uma dezena de empreendimentos foram lançados e a Tamboré S/A, dona das terras, abriu uma avenida com pista dupla e quatro faixas, doada a Santana de Parnaíba. Ao longo da avenida, só a Fernandez Mera já comercializou nove empreendimentos, que somam 1.078 casas, 360 terrenos, 2 prédios comerciais com 118 conjuntos e 15 edifícios residenciais com 880 apartamentos.

Os dados obtidos no levantamento realizado pela FAUUSP em 2005 ressaltam que

Os lançamentos imobiliários se concentram nas rodovias Castello Branco e Régis Bittencourt, sendo que a primeira teve maior valorização que a segunda.(p.82) [...] As regiões de Alphaville, Tamboré e Granja Viana se destacam entre as demais localizações da Zona Oeste em termos de ofertas de imóveis e de valorização imobiliária, o que faz sentido, independentemente do Rodoanel, pela presença dos conhecidos condomínios fechados na região. [...] não é possível deixar de considerar que a construção do Trecho Oeste deu maior "fôlego" para a manutenção desta faixa de mercado, em especial no que tange à facilidade de alternativas de acesso à cidade de São Paulo.(p.87)

“O surgimento das cidades tipo 'edge city' (cidade de entorno com recursos próprios) na periferia das grandes metrópoles motivou o interesse corporativo privado e fez o interesse público desenvolver-se e modernizar-se.” (REVISTA VIVA SÃO PAULO, 2006). Destaca-se nesta região, os condomínios Alphaville e Tamboré, construídos anos antes da implantação do Rodoanel, incentivados pela abertura da rodovia Castello Branco e o surgimento de centros de serviços e comércios.

Ainda nas proximidades da rodovia Castello Branco, há outros empreendimentos residenciais de alto padrão implantados após a construção do Rodoanel. Como propaganda dos condomínios é ressaltada a área verde, os parques, a segurança, a auto-sustentabilidade e a proximidade as rodovias Castello Branco e Rodoanel. É o que a autora Lencioni (2008) denomina "ilhas urbanas".

"Esse é o caso das áreas de condomínios fechados [...] onde o que importa não é tanto o contato com o seu entorno, mas o acesso a alguma autopista." (LENCIONI, 2008, p.10). 
Com a idealização, projeção e construção do Rodoanel, círculo rodoviário em torno da Grande São Paulo, e, concluída a 'fase Oeste' do sistema, em finais de 2002, a região de Alphaville tornou-se, como Tamboré, exemplo de pólo de desenvolvimento residencial e empresarial, ajudando a descentralizar os serviços que já abarrotavam o centro paulistano: 500 indústrias migraram para a região de Barueri [...] De acordo com os dados da Secretaria da Indústria e do Comércio atualmente há cerca de 4.000 estabelecimentos comerciais e escritórios, os quais totalizam uma área de $302.000 \mathrm{~m}^{2}$. A expansão da região e a melhoria de acesso mostram que o mercado imobiliário continua aquecido. (REVISTA VIVA SÃO PAULO, 2009)

Os novos condomínios como Morada da Serra e Morada da Aldeia, também de alto padrão, são valorizados pela proximidade com a rodovia Castello Branco e Rodoanel.

Alguns municípios no entorno do trecho oeste do Rodoanel não possuem legislação atual de uso e ocupação do solo ou as informações estão desatualizadas.

A falta de diretrizes, muitas vezes, prejudica a instalação de novos empreendimentos e o planejamento urbano.

Em Cotia, por exemplo, as plantas de zoneamento (década de 80) apresentadas pelos técnicos entrevistados não incluem o traçado do Rodoanel já construído. Em grande parte dos municípios tampouco existe um mapeamento atualizado dos assentamentos precários [...] o que se destaca na análise, mesmo que sucinta, das legislações de uso e ocupação do solo e Planos Diretores dos municípios afetados pelo anel viário, é a falta de homogeneidade e de tratamento integrado do território, em relação ao Rodoanel. (FAUUSP, 2005, p.92, 95).

Os técnicos alegam que as Prefeituras não possuem suporte, nem repasse de verbas, para aumento das atividades de fiscalização vinculadas ao empreendimento do Rodoanel. Além disso, as atribuições repassadas para o município, principalmente em termos de fiscalização, não são acompanhadas de previsão orçamentária própria para estas ações. (FAUUSP, 2005, p.96) 
No que diz respeito a faixa de domínio da DERSA, a partir do ano de 2007 foi observado o plantio de mudas de árvores, o que indica uma preocupação com o uso e ocupação do solo às margens da rodovia e com a recuperação de áreas utilizadas e degradadas ainda durante a execução da obra. (Fotos 177 e 178).
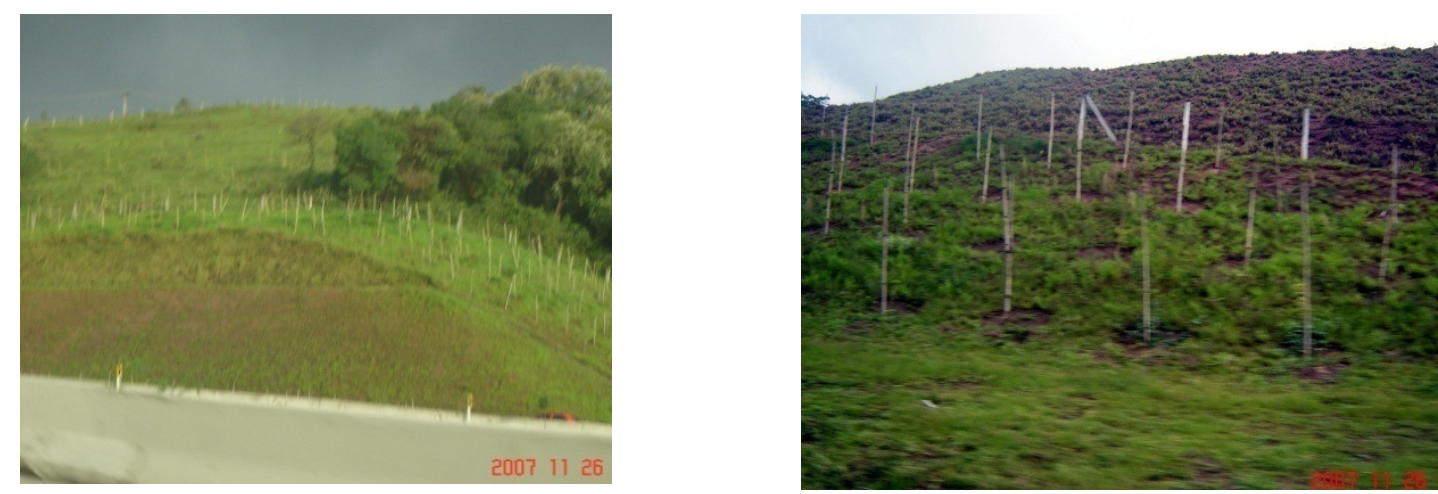

Fotos 177 e 178: Plantio de mudas no entorno da rodovia (2007) Fotos da autora

Nos últimos dois anos, analisando anúncios relativos a vendas e aluguéis nas proximidades do Rodoanel Mario Covas, trecho oeste, é possível observar muitos galpões industriais novos ou terrenos para construções de novos empreendimentos, como condomínios (industriais ou residenciais). Estes anúncios são relativos a áreas próximas ao Rodoanel, principalmente nas cidades de Osasco, Embu, Cotia, Itapecerica da Serra e Taboão da Serra que se referem ao trecho após o túnel de acesso a Osasco. Dos 20 anúncios visitados, apenas 3 áreas industriais estão localizadas nos bairros de São Paulo nas proximidades do trecho oeste mapeado, o restante espalham-se pelo município após o túnel de acesso a Osasco.

É possível citar o trabalho elaborado pela DERSA sobre a "Análise da evolução das alterações no uso do solo nas imediações do trecho oeste do Rodoanel Mario Covas" (SÃO PAULO, 2005a), que teve como objetivo caracterizar as alterações no uso e ocupação do solo em uma faixa de $1 \mathrm{~km}$ de largura ao longo do eixo viário no período de 1994 a 2005. Segundo o relatório, as alterações ocorridas no trecho após o túnel de acesso a Osasco foram: 
- Alterações positivas: 6 áreas de remoção de favela na faixa de domínio do rodoanel, construção de 2 escolas, uma biblioteca municipal e quadras poli-esportivas, instalação de indústria e de áreas industriais, construção de 3 conjuntos habitacionais, de um condomínio, um piscinão contra enchentes e ampliação do bairro Santo Antonio, ampliação de conjunto habitacional em Osasco; criação de um corredor industrial nas margens do rodoanel, instalação de áreas industriais/comerciais em Barueri, também é válido ressaltar a ampliação do condomínio Tamboré; ampliação do Parque dos Paturis, implantação de área industrial/comercial, ampliação de Parque Industrial e construção de um centro de distribuição em Carapicuíba; instalação de área industrial Colgate/Palmolive, construção do $16^{\circ}$ Batalhão da Polícia Militar e um Centro de Detenção Provisória em São Paulo; remoção de favela em Cotia e favelas removidas e instalações industriais em Taboão da Serra.

- Alterações negativas: expansão da Favela Parque Imperial em Santana do Parnaíba e expansão da favela Parque Industrial, ampliação de favelas nas margens do rodoanel em Osasco; ampliação de favela nas margens do rodoanel em Carapicuíba; invasão de terreno (futuro CEAGESP) em São Paulo; ampliação de favela e invasão de terrenos em Taboão da Serra.

Este estudo (SÃO PAULO, 2005a) concluiu que, em todo trecho oeste do Rodoanel, houve $61 \%$ de classificação positiva, $23 \%$ neutra e $16 \%$ negativa. Como alteração positiva foram consideradas ampliações de áreas comerciais, industriais que geraram impactos econômicos positivos, segundo o documento; e aquelas que contribuíram positivamente com a qualidade ambiental como construção de conjuntos habitacionais, revitalização de áreas urbanas (implantação de infra-estrutura), retirada de favelas, construções de parques e obras contra enchentes. Como alteração neutra o documento considera aquelas que foram compensadas ou estão sendo recompostas, e áreas de ampliação natural dos bairros existentes (desapropriações, áreas de empréstimo ou bota-fora, canteiros de obra). As alterações negativas são aquelas que tiveram impacto negativo para a sociedade, gerando degradação na qualidade de vida como surgimento ou ampliação de favelas, invasão de terrenos.

O relatório "Análise temporal por expansão urbana por Imagens LandSat" desenvolvido pela DERSA no ano de 2005 realizou uma análise multitemporal utilizando imagens de satélite (LandSat e LandSat 7) e conclui que: em 1985 a área ocupada na 
influência direta do Rodoanel (2000m, 1000m, 500m e faixa de domínio), era de 23,962500 $\mathrm{km}^{2}$ e a não ocupada de $137,359800 \mathrm{~km}^{2}$. Já no ano de 2004, onde o Rodoanel já se encontrava em plena operação, a área ocupada era de $67,831200 \mathrm{~km}^{2}$ e a não ocupada de $93,491100 \mathrm{~km}^{2}$ (SÃO PAULO, 2005c).

As curvas de Expansão Urbana positiva se acentuam a partir de 1993 e tem outro pico em 1997 [...] A curva dos 2000m (a mais distante do atual traçado do Rodoanel) é a que apresenta, neste período de 1993 a 2004 os maiores índices de crescimento, e a curva de $500 \mathrm{~m}$ (a mais próxima do atual traçado do Rodoanel) é aquela que apresenta os menores índices de crescimento [...] Este processo de conurbação vem ocorrendo há muitos anos e nenhum empreendimento pontual alterará o seu ritmo de expansão, sem que haja um redirecionamento da Política Metropolitana. E Projetos do porte do Rodoanel, se não tem a força para reverter este estado de coisas, poderá ser um bom colaborador. quando implantado e fizer parte de um Órgão Metropolitano competente [... ] os maiores pólos de adensamento ocorrem no sentido da conurbação Carapicuíba - Osasco - São Paulo, fenômeno este, bastante antigo, que antecede até mesmo à implantação da Rodovia Castelo Branco; ao longo de Rodovias abertas nas quais houve forte investimento público e privado no sentido de incentivar tal processo (Rodovia Castelo Branco). Destaca a análise, que mesmo as Rodovias abertas, quando não ocorrem investimentos intencionais pesados, o adensamento não ocorre (Rodovias Régis Bittencourt, Raposo Tavares, Anhanguera, Bandeirantes). Estas últimas Rodovias com baixos índices de expansão no entorno do Rodoanel, têm estes índices elevados, nos anéis periféricos mais próximos da capital Paulista, que reforça a afirmação de ocorrência de uma expansão radiocêntrica da cidade de São Paulo. Oportunamente, na medida das necessidades estes índices poderão ser determinados e quantificados rigorosamente (SÃO PAULO, 2005c, p. 7-9).

\subsubsection{Análise das alterações na paisagem urbana na área de estudo}

Segundo o relatório "Análise da Evolução das Alterações no Uso do Solo nas Imediações do Trecho Oeste" (SÃO PAULO, 2005a), o resultado foi dividido em três categorias: positiva (alterações que geraram impactos que contribuíram positivamente para a qualidade ambiental e para o crescimento da atividade econômica); neutra (alterações que foram ou estão sendo compensadas e as ampliações naturais de bairros já existentes, que ocorreriam independentemente da instalação do Rodoanel); e negativa (alterações que geraram degradação na qualidade ambiental).

No trecho estudado foi considerada "alteração negativa" pelo relatório (SÃO PAULO, 2005a), a expansão do Recanto dos Humildes (Recanto da Paz) e a ampliação da Favela Jardim Jaraguá (Morro Doce). Como "alteração neutra" dois pontos de desapropriação próximo a avenida Raimundo Pereira de Magalhães, dois pontos de desapropriação próximo 
às alças de acesso a rodovia Anhanguera e uma área de bota-fora já no Morro de Jesus. Como “alteração positiva”, a ampliação do cemitério Parque Jaraguá, próximo a rodovia Anhanguera, e uma área industrial também próxima a esta rodovia e a construção de uma pista de aeromodelismo próxima a rodovia dos Bandeirantes. No presente trabalho foram considerados, no que diz respeito às alterações ocorridas:

- Positivas: Readequação ambiental; preservação de fragmentos de mata e nascentes; acessos formais das vilas às rodovias; estabilização de taludes; aumento da ocupação residencial seguida do aumento de infra-estrutura e de planejamento; reformas e reestruturação de equipamentos públicos; instalação de galpões industriais respeitando áreas próprias; melhorias nas rodovias como alças de acesso; retornos e passarelas; retirada de favelas, construção de conjuntos residenciais populares em locais próprios, construção de novos equipamentos públicos.

- Neutras: ausência de transformações significativas de 1994 a 2009, como crescimento internos das vilas ou pequenas obras em residências;

- Negativas: aumento de ocupação residencial sem o aumento de infra-estrutura adequada; abandono ou mal uso de equipamentos públicos; destruição de fragmentos de mata sem novas propostas de reflorestamento, assoreamento de nascentes e corpos d'água, construção de galpões industriais em locais inadequados, construções na faixa de domínio das rodovias, desapropriação, avanço de casas sobre fragmentos de mata, construções em áreas de risco, remoção de camada vegetal.

Foram visitados ao todo 65 pontos e foram registradas 145 alterações, onde cerca $47,50 \%$ foram negativas, $40,60 \%$ positivas e $11,70 \%$ neutras. 


\section{CONSIDERAÇÕES FINAIS}

A utilização de imagens aéreas, a aplicação de técnicas e os trabalhos de campo são fundamentais para analisar o crescimento da mancha urbana metropolitana. No presente trabalho, foram utilizadas imagens aéreas de diferentes datas, técnicas de geoprocessamento e o ambiente SIG. Esta união resultou em um levantamento quantitativo de informações. As técnicas de classificação utilizadas possibilitaram a caracterização e quantificação do uso e ocupação do solo. A classificação analógica mostrou-se mais adequada para elaboração de mapas temáticos, enquanto que a classificação automática supervisionada mostrou-se mais adequada para levantamento de dados quantitativos, por ser mais detalhada, considerando regiões menores. A classificação analógica é baseada na interpretação visual que mostra-se útil na detecção de formas maiores, aquelas mais visíveis aos olhos do observador, menos detalhadas. O uso de imagens aéreas, junto com a análise histórica e trabalhos de campo possibilitou um levantamento qualitativo das transformações da mancha urbana.

As imagens de alta resolução IKONOS mostraram resultados adequados na interpretação e classificação dos elementos da paisagem, enquanto as fotografias aéreas apresentaram alguns problemas de definição, mesmo após tratamentos.

A união de dados quantitativos e qualitativos permitiram uma visão do cenário atual e subsídios pra a construção de cenários futuros do entorno do trecho oeste do Rodoanel Mario Covas na cidade de São Paulo.

No trecho que abrange o bairro de Perus seguindo até o túnel de acesso ao município de Osasco (Morro de Jesus) não houve significantes alterações no uso do solo. Neste trecho predomina desde 1994, o uso residencial, embora algumas empresas tenham sido instaladas no decorrer das rodovias mais antigas, Anhanguera e Bandeirantes.

No geral, as ocupações são de construções de baixa qualidade (autoconstrução, casas de madeirite, alvenaria sem acabamento), há carência de infra-estrutura como asfalto, iluminação pública e muitas construções encontram-se em áreas que avançam sobre fragmentos de mata. Pode-se dizer que, desde 1994 a implantação de infra-estrutura não acompanha o crescimento da ocupação neste trecho.

Diante destas situações de contradição e antagonismo entre crescimento de ocupações residenciais e carência na implantação de infra-estrutura básica como asfalto e iluminação pública, determinação de áreas próprias para ocupação residencial e vias de 
acesso, a paisagem apresenta pontos de degradação quando são observados os avanços de construções residenciais sobre áreas de mata, fragmentos de mata não inseridos na qualidade ambiental das vilas, vias de acesso informais para rodovias, corpos d'água assoreados e poluídos, ocupação de áreas muito próximas às rodovias, surgimento ou aumento da favelização. Em contrapartida ocorrem oásis que diferem do restante da paisagem quando são observadas as casas de alto padrão e os condomínios fechados com infra-estrutura adequada e que aproveitam os fragmentos de mata para obter melhor qualidade ambiental.

Quando o trecho oeste do Rodoanel Mario Covas foi construído, o seu entorno já era intensamente antropizada, com predominância de uso residencial, com presença de áreas preservadas pelo poder público muito próximas a ocupações humanas. A paisagem urbana, desde a construção do eixo viário, vem sendo alterada gradativamente principalmente em suas proximidades e em áreas de entroncamento com outros eixos viários construídos anteriormente, onde já havia outras ocupações. Nos últimos 15 anos, as alterações na paisagem urbana no entorno do trecho oeste do Rodoanel Mario Covas, nos bairros de Perus, Jaraguá e Santa Fé, ocorreram principalmente devido ao crescimento das ocupações residenciais sem infra-estrutura adequada e em locais impróprios, podendo ser vistas ou não do Rodoanel, deixando marcas que são representadas pela paisagem urbana. 


\section{REFERÊNCIAS}

AB'SABER. Os domínios de natureza no Brasil: potencialidades paisagísticas. São Paulo: Ateliê Editorial, 2003. p. 159.

ALMEIDA, G. E. S. Análise do índice de instalação de empresas no município de Osasco utilizando sistemas de informação geográfica e análise envoltória de dados - DEA. 2006. Dissertação (Mestrado em Engenharia) - Escola de Engenharia Politécnica da Universidade Estadual de São Paulo, São Paulo, 2006.

ANDRADE, M. C. de. O que é geografia. In: ANDRADE, M. C. de (org.). A Geografia como Ciência. São Paulo: Atlas, 1987.

BARBON, A. L. Mobilidade residencial intra-urbana em grandes centros - Região Metropolitana de São Paulo - estudo de caso. In: Encontro Nacional de Estudos Populacionais, n. 14, 2004, Caxambu. Anais... Caxambu, 2004.

BERTRAND, G. Paisagem e Geografia Física Global: esboço metodológico. São Paulo. Caderno de Ciências da Terra, São Paulo, n. 13, p. 1-25, 1971.

BIAS, E. de S.; LOMBARDO, M. A. A análise da precisão cartográfica dos produtos gerados a partir IKONOS Orthokit. In: GERARDI, L. de O.; LOMBARDO, M. A. (Org). Sociedade e Natureza na visão da geografia. Rio Claro: Ageteo, 2004. p. 29-46

BLANCO, M. A vez do boom industrial. Revista Construção: mercado, negócios de incorporação e construção. São Paulo: Editora PINI, n. 84, ano 61, p. 28 - 35, 2008.

BOESCH, H.; CAROL, H. Princípios do conceito de "paisagem". Boletim Geográfico, São Paulo, v. 27, n.202, p. $26-29,1968$.

BRASIL(a). Instituto Brasileiro de Geografia e Estatística. Carta topográfica de Guarulhos. Rio de Janeiro, 1984. 1 carta, PB. Escala 1:50000.

(b). Instituto Brasileiro de Geografia e Estatística. Carta topográfica de Santana do Parnaíba. Rio de Janeiro, 1984. 1 carta, PB. Escala 1:50000.

Instituto Brasileiro de Geografia e Estatística. Censo 2000. Disponível em http://www.ibge.gov.br. Acesso em: 21 jul 2007.

(a). Instituto Brasileiro de Geografia e Estatística. IBGE divulga as estimativas populacionais dos municípios em 2008. Disponível em: http://www.ibge.gov.br/home/presidencia/noticias/noticia_visualiza.php?id_noticia=1215\&id _pagina=1. Acesso em: 02 nov 2008. 
(b). Instituto Brasileiro de Geografia e Estatística. Países. Disponível em: http://www.ibge.gov.br/paisesat/. Acesso em: 02 nov 2008.

Instituto Brasileiro de Geografia e Estatística. Atlas Geográfico. 2 ed. Rio de Janeiro: IBGE, 2004. 204 p.

CARLOS, A. F. A. Espaço-Tempo na metrópole. São Paulo: Contexto, 2001. 368p.

CARNEIRO, Celso Dal Ré. 2002. Cavas de Ouro Históricas do Jaraguá, SP: os primórdios da mineração no Brasil. In: SCHOBBENHAUS, Carlos; CAMPOS, Diógenes de Almeida; QUEIROZ, Emanuel Teixeira de; WINGE, Manfredo; BERBERT-BORN, Mylène Luíza Cunha (Eds.). Sítios Geológicos e Paleontológicos do Brasil. Brasília: DNPM BRASIL. Departamento Nacional de Produção Mineral (DNPM)/Serviço Geológico do Brasil (CPRM). Comissão Brasileira de Sítios Geológicos e Paleobiológicos (SIGEP), 2002. p. 511-516.

CAVAlCANTI, A.; VIADANA, A. G. Organização do Espaço e análise da Paisagem. Rio Claro: UNESP/IGCE, 2007. 154 p.

CHAO, R. G. C. Geoprocessamento e Sensoriamento Remoto aplicado ao estudo da dinâmica urbana da província Ciudad de La Habana e na avaliação de ameaças de escorregamentos no município de Habana Del Este - CUBA. 1988. Dissertação (Mestrado em Recursos Minerais e Hidrogeologia). Instituto de Geociências. Universidade de São Paulo, São Paulo, 1998.

CHUVIECO SALINERO, E. Teledetección Ambiental: la observación de la Tierra desde el Espacio. Barcelona: Ariel, 2002. Contem Cd-rom.

CHRISTOFOLETTI, A. Modelagem de sistemas ambientais. Ed. Edgard Blucher, São Paulo, 1999. 236p.

DAMIANI, A. L. Urbanização crítica e situação geográfica a partir da metrópole de São Paulo. In: CARLOS, A. F. A.; OLIVEIRA, A. U. de. (Org.). Geografias de São Paulo: representação e crise na metrópole. São Paulo: Contexto, 2004.

DE ANGELIS, B. L. D; DE ANGELIS NETO, G. Paisagem, turismo e planejamento urbano. Acta Scientiarum. Maringá, v.4, n.20, p.537 - 543, 1998.

FERreirA, A. B. de H. Novo Dicionário da Língua Portuguesa. Rio de Janeiro: Nova Fronteira. $2^{\circ}$ ed., Rio de Janeiro, 1986.

FOLGATO, M. Rodoanel mudou, virou corredor de exportação. OESP Cidades. 11 jul 2004. p. C1, C3-C4. Disponível em: http://pib.socioambiental.org/pt/noticias. Acesso em: 20 jul 2009.

GERARDI, L. H. O.; SILVA, B. C. N. Quantificação em Geografia. São Paulo: Diefel, 1981. 
GLENNON, R. M.; GLENNON, J. A. Making better maps with ArcGis 9.2: using cartographic representations. Arc user: the magazine for ESRI software users. Santa Bárbara, Califórnia. v. 10, n. 3, p. 59 - 62, july -september, 2007.

HAHMANN, C. H.; MENDES, P.; PARRA, L. S.; SASAOKA, K.; GIMENEZ, W.; PAIVA, J. C. São Paulo Railway (1891-1975) E. F. Santos - Jundiaí (1975 - 1994) CPTM (1994 2009). Revista Ferrovias; Jornal da Tarde. 2004. [Mapas - acervo R. M. Giesbrecht]. Disponível em: http://www.estacoesferroviarias.com.br/j/jaragua.htm. [Página elaborada por Ralph Mennucci Giesbrecht]. Acesso em: 22 jul 2009.

HAMBURGER, D. S.; FORESTI, C. Utilização de atributos, textura e da morfologia matemática na definição de classes de uso do solo urbano. Brazilian journal of ecology. n.2, Rio Claro, 1997, p. 22 - 35.

HO, W. H.; LEE, G. H. Study on Land Use Management with Geographic Information Systems. 2000.2 Disponível em: <http:///www.gisdevelopment.net/aars/arcs/2000/ps2/ps205.pdf.htm>. Acesso em: 18 jun 2007.

JORGE, J.; PINEDA, N.; FÉRNANDEZ, M. La teledetección em los estúdios de impacto ambiental em la planificacion de uma carretera. In: VII Congresso Nacional del Médio Ambiente, 2004, Madrid. Anais... Madrid, 2004.

LENCIONI, S. Concentração e centralização das atividades urbanas: uma perspectiva multiescalar. Reflexões a partir do caso de São Paulo. Revista de Geografia Norte Grande. n.39, p. $7-20,2008$.

LISBOA, M. V. Contribuição para a tomada de decisão na classificação e seleção de alternativas de traçado para rodovias em trechos urbanizados. Dissertação (Mestrado em Engenharia de Transportes) - Universidade de São Paulo, São Paulo, 2002.

LOMBARDO, M. A. Qualidade ambiental e planejamento urbano: considerações de método. 1995. Tese (Livre-docência em Geografia). Departamento de Geografia da Faculdade de Filosofia, Letras e Ciências Humanas, Universidade de São Paulo, São Paulo, 1995.

LUCHIARI, A.; KAWAKUBO, F. S.; MORATO, R. G. Aplicações do sensoriamento remoto na geografia. In: VENTURI, L. A. B. (Org). Praticando geografia: técnicas de campo e laboratório. São Paulo: Oficina de textos, 2005. p. 33-54.

MACIEL, C. A. A. Morfologia da paisagem e imaginário geográfico: uma encruzilhada ontognoseológica. GEOgraphia. Ano 3, n.6, p. 1-19, 2001.

MARTINELLI, M. Curso de Cartografia Temática. São Paulo: Contexto, 1991. 180p.

PEDROTTI, F. A cartografia das unidades de paisagem: questões metodológicas.

Revista do Departamento de Geografia. São Paulo, n.14, p. 39-46, 2001. 
MAXIMIANO, L. A. Considerações sobre o conceito de paisagem. Curitiba: UFPR, n.8, p.83-91, 2004.

MEIO físico: apresentação. In: SÃO PAULO (Cidade). Prefeitura Municipal. Secretaria Municipal do Verde e do Meio Ambiente. Secretaria Municipal de Planejamento Urbano. Atlas ambiental do município de São Paulo. São Paulo,

[2007?]. Disponível em: <http://atlasambiental.prefeitura.sp.gov.br/pagina.php?id=28> . Acesso em: 1 ago 2007

METZGER, J .P. O que é ecologia de paisagens? Biota neotropica. São Paulo, v.1, n.12, p. 1-8, nov 2001. Disponível em: <http://www.biotaneotropica.org.br/v1n12/pt>. Acesso em 22 mai 2007. p. 1-8.

MONTEIRO, C. A. F. Geossistema: a história de uma procura. São Paulo: Contexto, 2000.

MOREIRA, M. A. Fundamentos do Sensoriamento remoto: metodologias de aplicação. Viçosa: Ed. UFV, 3 ed. atualampl, 2005.

NIERO, M. Utilização de dados orbitais do LANDSAT-1 na classificação de uso do solo urbano de São José dos Campos. Dissertação (Mestrado em Sensoriamento Remoto) Instituto de Pesquisas Espaciais. São José dos Campos, 1977.

NOVO, E, M. L. de. Sensoriamento remoto: princípios e aplicações. São José dos Campos: Edgard Blucher, 1988. 308 p.

OSASCO. Prefeitura Municipal. Museu Municipal Dimitri Sensaud De Lavaud. Prefeitura Municipal. Osasco, 2007. Disponível em: http://www.osasco.sp.gov.br/materia.asp?. Acesso em 30 jul 2007.

PANCHER, A. M.; FREITAS, M. I. C. de. "Brownfields" têxteis em Americana. In: Seminário da Pós Graduação em Geografia da UNESP de Rio Claro. 4, 2004, Rio Claro. Anais... [2004].

PARQUE do Jaraguá: apresentação. In: SÃO PAULO (Estado). Parque Estadual do Jaraguá. São Paulo, [2008?]. Disponível em: http://www.picodojaragua.com.br/pico.html. Acesso em: 9 jun 2008.

PENIDO, L.R.; KUX, H. J. H.; MATTOS, J. T. de. Aplicação de Técnicas de sensoriamento remoto e GIS como subsídio ao planejamento rodoviário. Estudo de Caso: Trecho Oeste do Rodoanel Metropolitano de São Paulo, Brasil. In: SIMPÓSIO BRASILEIRO DE SENSORIAMENTO REMOTO, 1998, Santos. Anais..., [1998]. p. 661-673. 
PEREIRA, M. N.; GONÇALVES, C. D. A. B.; SOUZA, I. de M. e; GARCIA, S.; PORTELA, A. da G.; ALMEIDA, C. M. de; ROSEMBACK, R.; FLORENZANO, T. G. Uso de imagens de satélite como subsídio ao estudo do processo de urbanização. Instituto Nacional de Pesquisas Espaciais. São José dos Campos, 2005.

PINHO, C. M. D. de. Análise orientada a objetos de imagens de satélite de alta resolução espacial aplicada à classificação de cobertura do solo no espaço intra-urbano: o caso de São José dos Campos - SP. Dissertação (Mestrado em Sensoriamento Remoto) - Instituto Nacional de Pesquisas Espaciais, São José dos Campos, 2006.

QUEIROZ FILHO, A. P. A escala nos trabalhos de campo e no laboratório. In: VENTURI, L. A. B (Org). Praticando Geografia: técnicas de campo e laboratório. São Paulo: Oficina de Textos, 2005. p.55-67

RODRIGUEZ, J. M. M.; SILVA, E. V. da; CAVALCANTI, A. P. B. Geoecologia das paisagens: uma visão geossistêmica da análise ambiental. Fortaleza: UFC, 2004.

SANTOS, M. Manual de geografia urbana. São Paulo: Hucitec, 1981. 203 p.

Espaço \& Método. São Paulo: Nobel, 1985. 88 p.

Metamorfoses do espaço habitado. São Paulo: Hucitec, 1988. 124 p.

A Natureza do Espaço: técnica e tempo, razão e emoção. 3. ed: São Paulo: HUCITEC, 1999. 308 p.

A urbanização brasileira. São Paulo: Edusp, 2005. 176 p.

SANTOS, R. F. dos. Planejamento Ambiental: teoria e prática. São Paulo: Oficina de Textos, 2004.

SÃO PAULO (Estado). Empresa Paulista de Planejamento Metropolitano SA. Memória urbana: a Grande São Paulo até 1940. Arquivo do Estado. Imprensa Oficial, São Paulo, 1989.

$\begin{array}{llcccc} & \text { Secretaria dos } & \text { Transportes. } & \text { PDDT - Plano Diretor de } & \text { Desenvolvimento de } \\ \text { Transportes. } & \text { São } & \text { Paulo, } & 2000, & \text { PDDT. } & \text { Disponível }\end{array}$ http://www.transportes.sp.gov.br/v20/rodoanel.asp. Acesso em 13 mar 2008.

Fundação Sistema Estadual de Análise de Dados. Região Metropolitana de São Paulo. São Paulo, SEADE, 2002. [Slides] Disponível em: http://www.seade.gov.br/produtos. Acesso em 10 mar 2008.

Desenvolvimento Rodoviário SA - DERSA. Avaliação Ambiental Estratégica: transporte para o desenvolvimento sustentável. São Paulo: DERSA, 2004.

(a). Desenvolvimento Rodoviário SA - DERSA. Análise da evolução das alterações no uso do solo nas imediações do trecho oeste do Rodoanel Mario Covas. São Paulo: DERSA, 2005. 
(b). Desenvolvimento Rodoviário SA - DERSA. O Rodoanel e a ocupação urbana em seu entorno. São Paulo: DERSA, 2005.

(c). Desenvolvimento Rodoviário SA - DERSA. Análise Temporal da expansão urbana por imagens LandSat. São Paulo: DERSA, 2005.

. Empresa Paulista de Planejamento Metropolitano SA. Metrópoles em dados:

Região Metropolitana de São Paulo. São Paulo, 2007. Disponível em http://www.emplasa.sp.gov.br/. Acesso em 13 mar 2007.

Fundação Sistema Estadual de Análise de Dados. Perfil Municipal. São Paulo: SEADE, 2007. Disponível em: http://www.seade.gov.br/produtos/perfil/perfil.php. Acesso em 18 fev 2008.

SIQUEIRA, E. Companhia Brasileira de Cimento Portland Perus: contribuição para uma história da indústria pioneira do ramo no Brasil (1926-1987). Dissertação (Mestrado em História Econômica). Faculdade de Ciências e Letras, Universidade Estadual Paulista, Araraquara, 2001.

SOTCHAVA, V. B. O estudo dos Geossistemas. Métodos em Questão, São Paulo, vol.16, p. $1-52,1976$.

SPRING. Integrating remote sensingand GIS by object-oriented data modelling. Camara, G.; Souza, R. C. M.; Freitas, U. M.; Garrido, J. Computers \& Graphics, 20: (3) p. 395-403, May-Jun, 1996. Disponível em: http://www.dpi.inpe.br/geopro/trabalhos/spring.pdf. Acesso em 01 set. 2009.

TOGNOLLI, C. J. MP - SP entra com ação ambiental contra obra do Rodoanel. Site Consultor Jurídico - Notícias, 2006. Disponível em: http://www.conjur.com.br/2006-mar01/mp-sp_entra_acao_ambiental_obra_rodoanel?pagina=8. Acesso em 03 mai 2009.

TRICART. J. F. Paisagem \& Ecologia. Traduzido por Carlos Augusto Figueiredo Monteiro. São Paulo: IGEO/USP, 1981.

TROLL,C. Landscape Ecology (geo-ecology) and biogeocenology: a terminological study. Geoforum, p. 43-46, 1971.

TROPPMAIR, H. Biogeografia e Meio Ambiente. 4. ed. Rio Claro: edição do autor, 1995.

TUTORIAL SPRING. Introdução ao Spring. São José dos Campos, 2002. Disponível em: http://www.dpi.inpe.br/spring/portugues/download.php. Acesso em 20 jun 2004. 
VENTURI, L. A. B. O papel da técnica no processo de produção científica. VENTURI, L. A. B. (Org). Praticando geografia: técnicas de campo e laboratório. São Paulo: Oficina de Textos, 2005. p.13-18 2006.

Recurso Natural: a construção de um conceito. Geousp, São Paulo, n. 20, p. 6-18,

VILLAÇA, F. Espaço intra-urbano no Brasil. São Paulo: Studio Nobel / Lincoln Institute / FAPESP, 2001. 373 p.

VITTE, A. C. O Desenvolvimento do conceito de paisagem e a sua inserção na geografia física. Mercator. Ano 06, n.11, p. 71 - 78, 2007. 